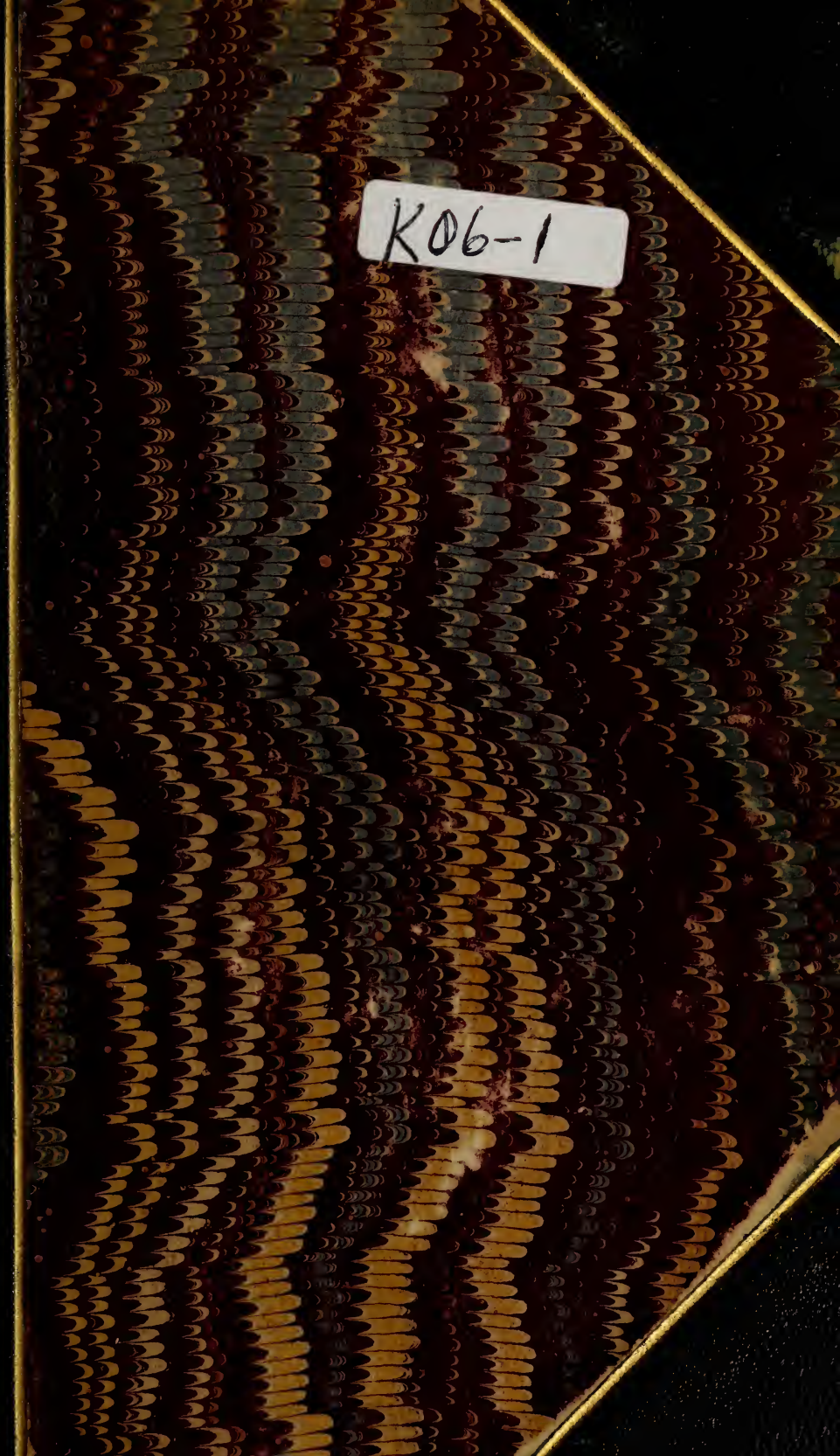




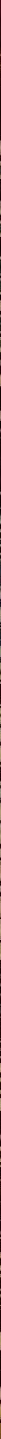




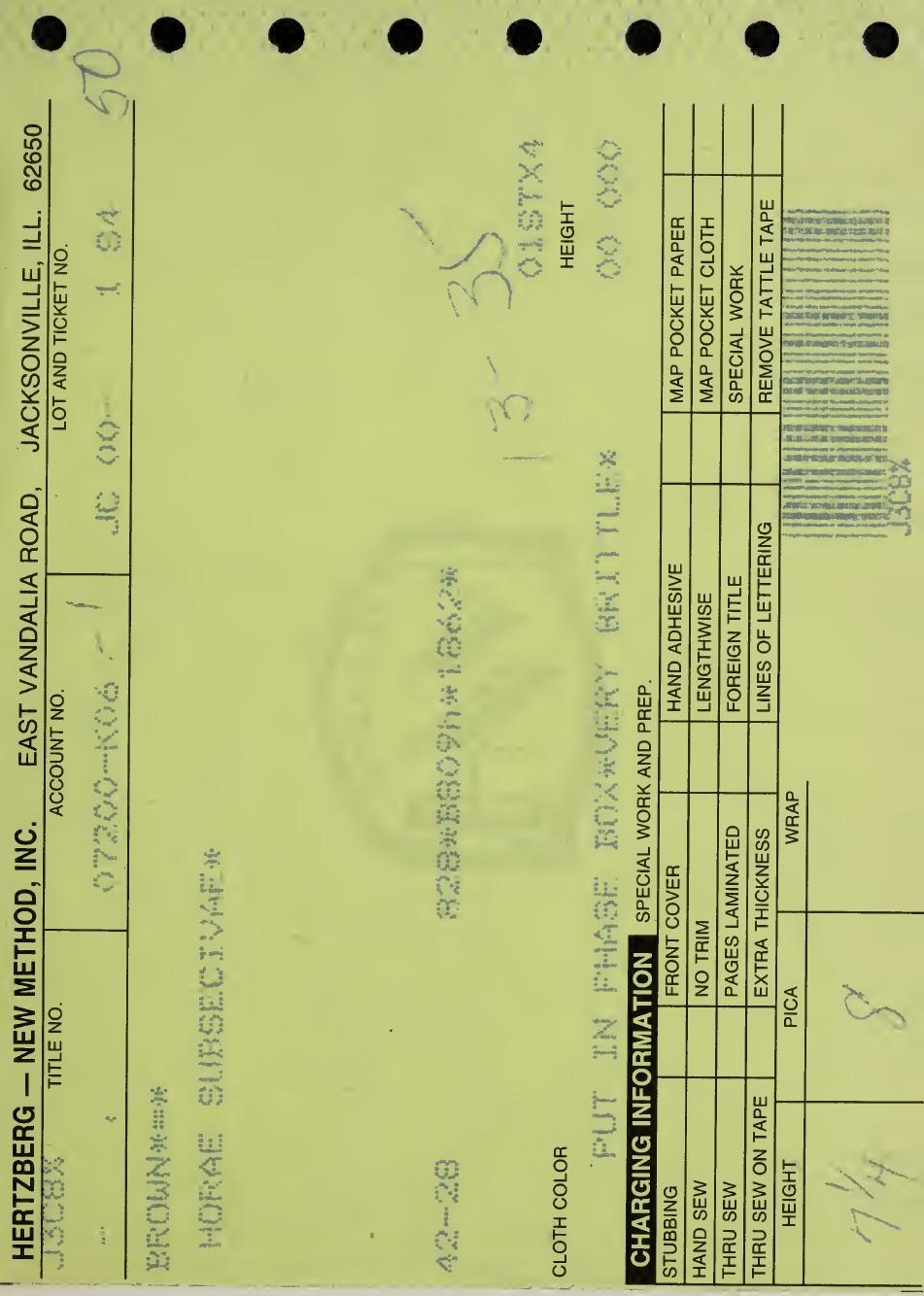





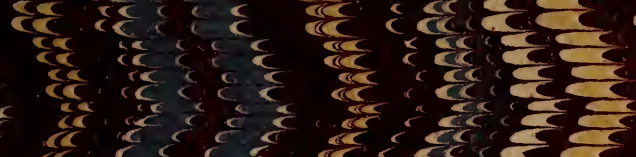

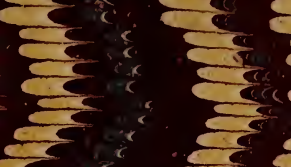

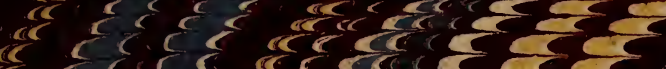

$C<C<C<C<C$

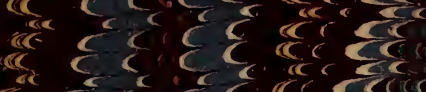

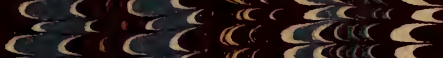

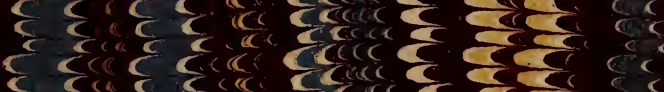

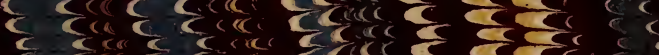

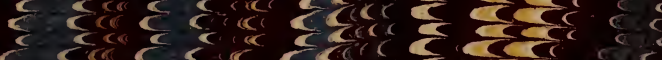

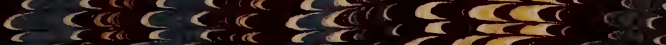

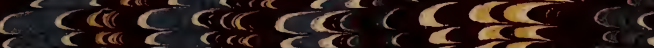

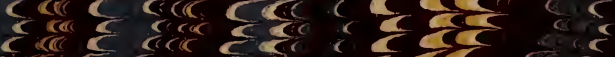

$<\mathrm{C} C \mathrm{C} C \mathrm{C}-\mathrm{C}$

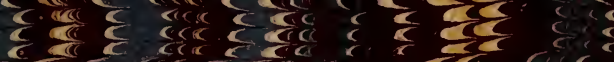

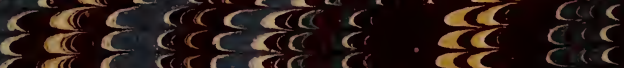

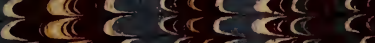

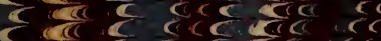

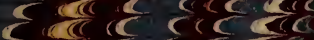

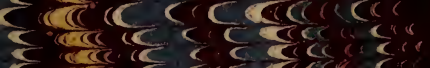

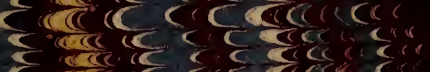

$C$

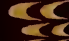

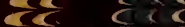

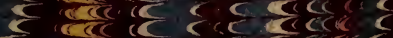

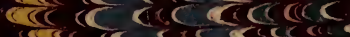

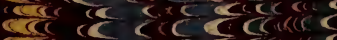

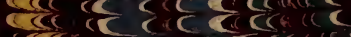

cer $\mathrm{sec} x \cos c c^{2}$

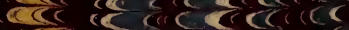

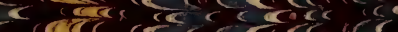

CCL $\cos C \mathrm{CLC}$

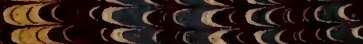

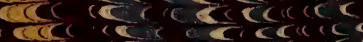

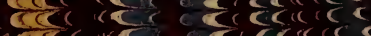

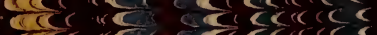

Cद c c c

CC, SC

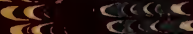

acisi coses

$\operatorname{sic}$ Sect

ack sica:

बise $\mathrm{c} x \mathrm{ccc}$

ace cesect

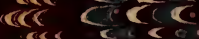

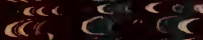

CCS C C

CC C C C

cis $s<$

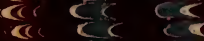

ar $c<c<$

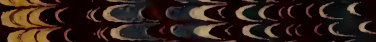

सह $C<<C$

$\Rightarrow 25$ बतa

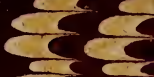
.
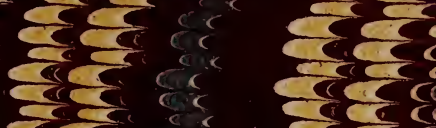

$\longrightarrow C$

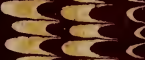

$\longrightarrow<c$

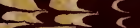

$\Longrightarrow<$

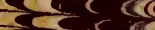
$\Rightarrow$

$\rightarrow C$

बC.

$\Rightarrow 5$ सर

$\longrightarrow$

बर्ब $\Rightarrow 5 \mathrm{C}$ $\Rightarrow<$ रे देर $\Rightarrow c \mathrm{cc}$ $\Rightarrow<\frac{c c}{6}$ सर के बरे तC $C$ लबख

बic $C$ Co

तe \& ख एक

संख खराख

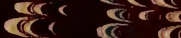

$\frac{\pi}{d} \frac{\pi}{d}$

2

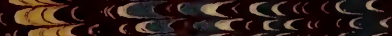
बद्व $c^{c}$

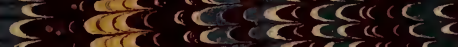

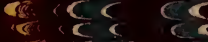

एक

$\frac{\mathbb{C}}{\mathrm{C}} \mathrm{C}$

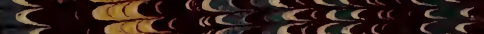

$\Rightarrow$ करो

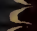
act $<c$ (c) $1<$ बC $c$ महै $C$ ini $c c$ , बत्ट $\frac{\pi}{5}$ खले बिक तर $\frac{15}{25}$ करत

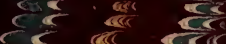
¿द बर $\operatorname{cic} c$ $c<$ रू करति

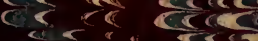

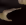

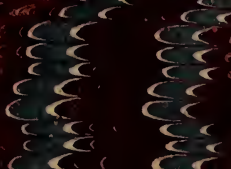

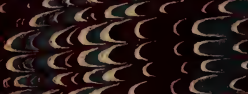

$$
\begin{aligned}
& C<
\end{aligned}
$$
- 5 


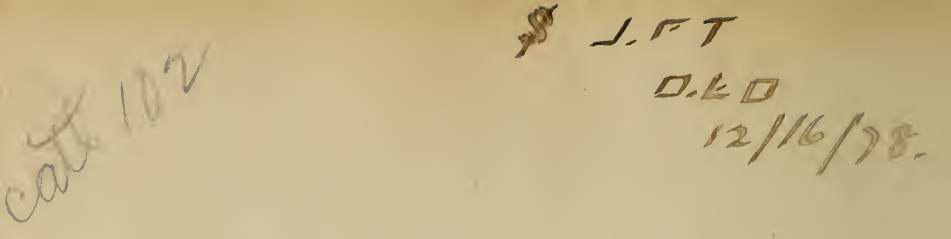

3 


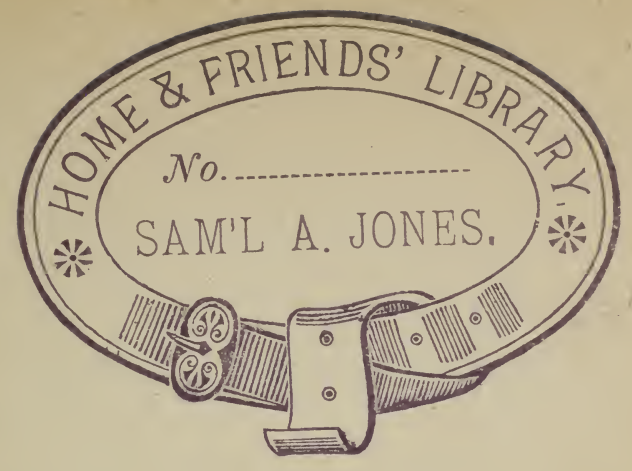

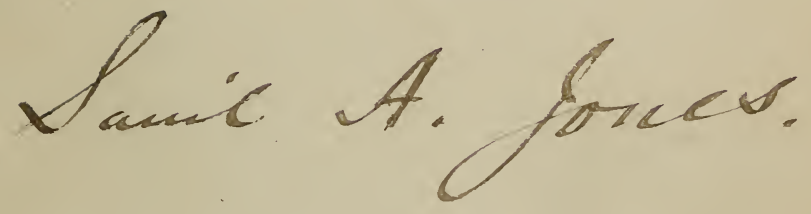


Digitized by the Internet Archive in 2016 


\section{HORAE SUBSECIVAE.}

'If thou be a severe, sour-complexioned man, then I herr disallow thee to be a competent judge.'-ISAAK WALTON.

'A lady, resident in Devonshire, going into one of her parlours, discovered a young ass, who had found its way into the room, and carefully closed the door upon himself. He had evidently not been long in this situation before he had nibbled a part of Cicero's Orations, and caten nearly all the index of a folio edition of Seneca in Latin, a large part of a volume of La Bruyere's. Maxims in French, and several pages of Cecilia. He had done no other mischief whatever, and not a vestige remained of the leaves that he had devoured.'-PIERCE EGAN. 
Edinburgh: Printed by Thomas Constable,

FOR

EDMONSTON AND DUUGLAS.

LONDON....... HAMILTON, ADAMS, AND CO.

CAMBRIDGE . . . . MACMILLAN AND Co.

DUBLIN . . . . . . . W. ROBERTSON.

GLASGOW ....... JAMES MACLEHOSE. 


\section{HORÆ SUBSECIVÆ.}

By JOHN BROWN, M.D.

F. R. S. E.

' Ce fagotage de tant si diverses pièces, se faict en cette condition: que je n'y inets la main, que lors qu'une trop lasche oysifveté me tresse.'-MICHEL DE MONTAIGNE.

A NEW EDITION.

\section{EDINBURGH :}


'The treatment of the illustrious dead by the quick, often reminds me of the gravedigger in Hamlet, and the skull of poor defunct Yorick.'-W. H. B.

'Multi ad sapientiam pervenire potuissent, nisi se jam pervenisse putassent.'.

'There's nothing so amusing as human nature, but then you must have some one to laugh with.' - C. S. B.

'Fear is more pain than is the pain it fears.'-SIR P. SIDNEY. 


\section{8 \\ B809h 1862}

\section{PREFACE.}

SQUEEZE out the whey,' was the pithy and sharp advice of his crusty, acute, faithful, and ill-fated friend, William Taylor of Norwich, author of English Synonyms, to Southey, when that complacent and indefatigable poet and literary man of all work sent him the MSs. of his huge quartos. It would perhaps have been better for his fame had the author of Thalaba, Don Roderick, and The Curse of Kehama taken the gruff advice.

I am going to squeeze my two volumes into one, keeping it a profound secret as to what I regard as whey and what curd; only I believe the more professional papers, as Locke and Sydenham, Dr. Marshall, etc., are less readable-less likely to while away the idle hours of the gentle public, than those now given: they are squeezed out not without a grudge.

My energetic friend, J. T. Fields, of the well- 
known Boston firm, has done the same act of excision by the two volumes that I now do,- - and has done it admirably. Only I could not but smile when I saw Hore Subseciva exchanged for 'Spare Hours,'- a good title, but not mine; and my smile broke into laughter when I found myself dedicated 'affectionately' to an excellent man and poet, whom, to my sorrow, I do not know.

While thanking my American friends, and shaking hands with them across the great deep, I cannot deny myself the satisfaction of acknowledging the following portion of a letter received a day or two ago from an unknown friend-Charles D. Warner, of Hartford, Conn., U.S. :-

'I see you lay some stress upon the fact that your venerated father was very tenacious of purpose, and that that is a trait of the Browns. The branch of the family in this country also assert the same of themselves.

'In further reading how your father came, late in life, when it was too late, to know that he had neglected his body, I called to mind a remark of another Dr. Brown, which I thought you might like to hear, as confirmatory of your theory of the unity of the Browns. 
'Dr. John Brown, D.D., was a native of Brooklyn, in this State. He was settled at one time in Cazenovia, New York, and finally died at the age of fifty, prematurely worn out, at Hadley, Mass. He was a man of great tenacity of purpose, strength of intellect, . a clear thinker, and generally a powerful man. He was also much beloved, for his heart was large and warm.

'While he was waiting for death to overtake him, being undermined as I have said, I have heard my mother say that he once remarked, "I have worn myself out in labour which God never required of me, and for which man never will thank me.",

Those of my readers who think life in the main more serious than not, will forgive this grave and weighty passage. Those who do not think so, will not be the worse of asking themselves if they are safe in so doing.

J. B.

23, Rutland Street,

15th Feb. I862. 
Human wisdom has reached its furlhest point when it gets to say-I do not know-GoD knows. In the child's story of 'Beauty and the Beast,' the Beast says to Beauty, 'Do you not think me very ugly?' 'Why, yes,' said she, 'for I cannot tell a story.' 'You are right,' replied the Beast; ' and besides being ugly I am very stupid.' 'I think you cannot be very stupid,' said Beauty, 'if you yourself know this.'-From a thoughtful Discourse on Plato, by, I believe, a Liverpool Merchant. 


\section{O N T EN TS.}

PAGE

LETTER TO JOHN CAIRNS, D.D. . . . . . I

DR. CHALMERS . . . . . . . . III

DR. GEORGE WILSON . . . . . ${ }^{151}$

HER LAST HALF-CROWN . . * . . ${ }^{16} 6_{5}$

QUEEN MARY'S CHILD-GARDEN . . . . . I7I

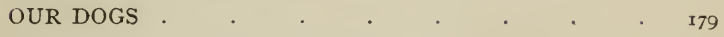

NOTES ON ART . . . . . . . . . 2 2 2

'OH, I'M WAT, WAT!' . . . . . . . 297

EDUCATION THROUGH THE SENSES . . . 309

ATXINOIA - NEARNESS OF THE NOY

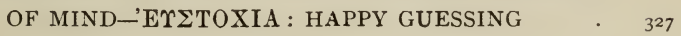

THE BLACK DWARF'S BONES · • • • 339

RAB AND HIS FRIENDS . . . . . ${ }_{3} 6_{3}$

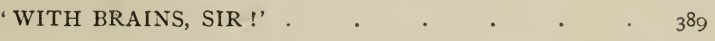

ARTHUR H. HALIAM . . . . . . $4^{17}$ 



\section{LETTER TO JOHN CAIRNS, D.D.}

'I praised the dead which are already dead, more than the liz'ns which are yet alive.' 
'As he was of the Pauline type of mind, his Christianity ran into the same mould. A strong, intense, and vehement nature, with masculine intellect and unyielding will, he accepted the Bible in its literal simplicity as an absolute revelation, and then showed the strength of his character in subjugating his whole being to this decisive infuence, and in projecting the same convictions into other minds. He was a believer in the sense of the old Puritans, and, amid the doubt and scepticism of the ninetcenth century, held as firmly as any of them by the doctrines of atonement and grace. He had most of the idiosyncrasy of Baxter, though not without the contemplation of Howe. The doctrines of Calvinism, mitigated but not renounced, and received simply as dictates of Heaven, without any effort or hope to bridge over their inscrutable depths by philosophical theories, he translated into a fervent, humble, and resolutely active life.

' There was a fountain of tenderness in his nature as well as a surep of impeluous indignation; and the one drawn out, and the other controlled by his Christian faith, made him at once a philanthropist and a reformer, and both in the highest departments of human interest. The union of these ardent elements, and of a highly devotional temperament, not untouched with meiancholy, with the patience of the scholar, and the sobriety of the critic, formed the singularity and almost the anomaly of his personal character. These contrasts were tempered by the discipline of experience; and his life, both as a man and a Christran, seemed to become more rich, genial, and harmonious as it approached its close.'-DR. CAIRNS. 


\section{Horæ Subsecive.}

\section{LETTER TO JOHN CAIRNS, D.D.}

23 Rutland Street, i5th August i860.

WY DEAR FrIEnd,-When, at the urgent request of his trustees and family, and in accordance with what I believe was his own wish, you undertook my father's Memoir, it was in a measure on the understanding that I would furnish you with some domestic and personal details. This I hoped to have done, but was unable.

Though convinced more than ever how little my hand is needed, I will now endeavour to fulfil my promise. Before doing so, however, you must permit me to express our deep gratitude to you for this crowning proof of your regard for him

'Without whose life we had not been ;'

to whom for many years you habitually wrote as 'My father,' and one of whose best blessings, when 
he was 'such an one as Paul the aged,' was to know that you were to him 'mine own son in the gospel.'

With regard to the manner in which you have done this last kindness to the dead, I can say nothing more expressive of our feelings, and, I am sure, nothing more gratifying to you, than that the record you have given of my father's life, and of the series of great public questions in which he took part, is done in the way which would have been most pleasing to himself - that which, with his passionate love of truth and liberty, his relish for concentrated, just thought and expression, and his love of being loved, he would have most desired, in any one speaking of him, after he was gone. He would, I doubt not, say, as one said to a great painter, on looking at his portrait, 'It is certainly like, but it is much betterlooking;' and you might well reply, as did the painter, 'It is the truth, told iovingly' - and all the more true that it is so told. You have, indeed, been enabled to speak the truth, or as the Greek has it, $\dot{\alpha} \lambda \eta \theta \epsilon v \epsilon \hat{\imath} \nu \stackrel{\text { } \epsilon}{\nu} \dot{\alpha} \gamma \alpha \dot{a} \pi \eta$ - to truth it in love.

I have over and over again sat down to try and do what I promised and wished-to give some faint expression of my father's life ; not of what he did or said or wrote-not even of what he was as a man of God and a public teacher; but what he was in his essential nature-what he would have been had he 


\section{Letter to Fohn Cairns, D.D.}

been anything else than what he was, or had lived a thousand years ago.

Sometimes I have this so vividly in my mind that I think I have only to sit down and write it off, and do it to the quick. 'The idea of his life,' what he was as a whole, what was his self, all his days, would, - to go on with words which not time or custom can ever wither or make stale,-

'Sweetly creep
Into my study of imagination ;
And every lovely organ of his life
Would come apparelled in more precious habit-
More moving delicate, and full of life,
Into the eye and prospect of my soul,
Than when he lived indeed ;'

as if the sacredness of death and the bloom of eternity were on it; or as you may have seen in an untroubled lake, the heaven reflected with its clouds, brighter, purer, more exquisite than itself; but when you try to put this into words, to detain yourself over it, it is by this very act disturbed, broken and bedimmed, and soon vanishes away, as would the imaged heavens in the lake, if a pebble were cast into it, or a breath of wind stirred its face. The very anxiety to transfer it, as it looked out of the clear darkness of the past, makes the image grow dim and disappear.

Every one whose thoughts are not seldom with the dead, must have felt both these conditions; how, in 
certain passive, tranquil states, there comes up into the darkened chamber of the mind, its 'chamber of imagery'-uncalled, as if it blossomed out of space, exact, absolute, consummate, vivid, speaking, not darkly as in a glass, but face to face, and 'moving delicate' - this 'idea of his life ;' and then how an effort to prolong and perpetuate and record all this, troubles the vision and kills it! It is as if one should try to paint in a mirror the reflection of a dear and unseen face; the coarse, uncertain passionate handling and colour, ineffectual and hopeless, shut out the very thing itself.

I will therefore give this up as in vain, and try by some fragmentary sketches, scenes, and anecdotes, to let you know in some measure what manner of man my father was. Anecdotes, if true and alive, are always valuable; the man in the concrete, the totus quis comes out in them; and I know you too well to think that you will consider as trivial or out of place anything in which his real nature displayed itself, and your own sense of humour as a master and central power of the human soul, playing about the very essence of the man, will do more than forgive anything of this kind which may crop out here and there, like the smile of wild-flowers in grass, or by the wayside.

My first recollection of my father, my first impression, not only of his character, but of his eyes and 


\section{Letter to Fohn Cairns, D.D.}

face and presence, strange as it may seem, dates from my fifth year. Doubtless I had looked at him often enough before that, and had my own childish thoughts about him ; but this was the time when I got my fixed, compact idea of him, and the first look of him which I felt could never be forgotten. I saw him, as it were, by a flash of lightning, sudden and complete. A child begins by seeing bits of everything; it knows in part - here a little, there a little; it makes up its wholes out of its own littles, and is long of reaching the fulness of a whole; and in this we are children all our lives in much. Children are long of seeing, or at least of looking at what is above them; they like the ground, and its flowers and stones, its 'red sodgers' and lady-birds, and all its queer things; their world is about three feet high, and they are more often stooping than gazing up. I know I was past ten before I saw, or cared to see, the ceilings of the rooms in the manse at Biggar.

On the morning of the 28th May i 816 , my eldest sister Janet and I were sleeping in the kitchen-bed with Tibbie Meek, ${ }^{1}$ our only servant. We were all

1 A year ago, I found an elderly countrywoman, a widow, waiting for me. Rising up, she said, 'D' ye mind me?' I looked at her, and could get nothing from her face; but the voice remained in my ear, as if coming from the "fields of sleep,' and I said by a sort of instinct, 'Tibbie Meek!' I had not seen her or heard her voice for more than forty years. She had come to get some medical advice. Voices are often like the 
three awakened by a cry of pain-sharp, insufferable, as if one were stung. Years after we two confided to each other, sitting by the burnside, that we thought that 'great cry' which arose at midnight in Egypt must have been like it. We all knew whose voice it was, and, in our night-clothes, we ran into the passage, and into the little parlour to the left hand, in which was a closet-bed. We found my father standing before us, erect, his hands clenched in his black hair, his eyes full of misery and amazement, his face white as that of the dead. He frightened us. He saw this, or else his intense will had mastered his agony, for, taking his hands from his head, he said, slowly and gently, 'Let us give thanks,' and turned to a little sofa in the room ; there lay our mother, dead. ${ }^{1}$ She had long been ailing. I remember her sitting in a shawl,an Indian one with little dark green spots on a light ground,- - and watching her growing pale with what I afterwards knew must have been strong pain. She had, being feverish, slipped out of bed, and 'grandmother,' her mother, seeing her 'change come,' had called my father, and they two saw her open her blue, kind, and true eyes, 'comfortable' to us all 'as the smells of flowers and leaves, the tastes of wild fruits-they touch and awaken the memory in a strange way. 'Tibbie' is now living at Thankerton.

1 This sofa, which was henceforward sacred in the house, he had always beside him. He used to tell us he set her down upon it when he brought her home to the manse. 


\section{Letter to Fohn Cairns, D.D.}

day'-I remember them better than those of any one I saw yesterday-and, with one faint look of recognition to him, close them till the time of the restitution of all things.

'She had another morn than ours.'

Then were seen in full action his keen, passionate nature, his sense of mental pain, and his supreme will, irstant and unsparing, making himself and his terrified household give thanks in the midst of such a desolation,- - and for it. Her warfare was accomplished, her iniquities were pardoned; she had already received from her Lord's hand double for all her sins : this was his supreme and over-mastering thought, and he gave it utterance.

No man was happier in his wives. My mother was modest, calm, thrifty, reasonable, tender, happyhearted. She was his student-love, and is even now remembered in that pastoral region for 'her sweet gentleness and wife-like government.' Her death, and his sorrow and loss, settled down deep into the heart of the countryside. He was so young and bright, so full of fire, so unlike any one else, so devoted to his work, so chivalrous in his look and manner, so fearless, and yet so sensitive and selfcontained. She was so wise, good and gentle, gracious and frank.

His subtlety of affection, and his almost cruel self- 
command, were shown on the day of the funeral. It was to Symington, four miles off,--a quiet little churchyard, lying in the shadow of Tinto; a place where she herself had wished to be laid. The funeral was chiefly on horseback. We, the family, were in coaches. I had been since the death in a sort of stupid musing and wonder, not making out what it all meant. I knew my mother was said to be dead. I saw she was still, and laid out, and then shut up, and didn't move; but I did not know that when she was carried out in that long black box, and we all went with her, she alone was never to return.

When we got to the village all the people were at their doors. One woman, the blacksmith Thomas Spence's wife, had a nursing baby in her arms, and he leapt up and crowed with joy at the strange sight, the crowding horsemen, the coaches, and the nodding plumes of the hearse. This was my brother William, then nine months old, and Margaret Spence was his foster-mother. Those with me were overcome at this sight; he of all the world whose, in some ways, was the greatest loss, the least conscious, turning it to his own childish glee.

We got to the churchyard and stood round the open grave. My dear old grandfather was. asked by my father to pray; he did. I don't remember his words; I believe he, through his tears and sobs, repeated the Divine words, 'All flesh is grass, and all the glory of 


\section{Letter to Fohn Cairns, D.D.}

man as the flower of the grass; the grass withereth, and the flower thereof falleth away, but the word of the Lord endureth for ever;' adding, in his homely and pathetic way, that the flower would again bloom, never again to fade; that what was now sown in dishonour and weakness, would be raised in glory and power, like unto His own glorious body. Then to my surprise and alarm, the coffin, resting on its bearers, was placed over that dark hole, and I watched with curious eye the unrolling of those neat black bunches of cords, which I have often enough seen since. My father took the one at the head, and also another much smaller springing from the same point as his, which he had caused to be put there, and unrolling it, put it into my hand. I twisted it firmly round my fingers, and awaited the result; the burial men with their real ropes lowered the coffin, and when it rested at the bottom, it was too far down for me to see itthe grave was made very deep, as he used afterwards to tell us, that it might hold us all-my father first and abruptly let his cord drop, followed by the rest. This was too much. I now saw what was meant, anci held on and fixed my fist and feet, and I believe my father had some difficulty in forcing open my small fingers ; he let the little black cord drop, and I remember, in my misery and anger, seeing its open end disappearing in the gloom.

My mother's death was the second epoch in my 
father's life; it marked a change at once and for life; and for a man so self-reliant, so poised upon a centre of his own, it is wonderful the extent of change it made. He went home, preached her funeral sermon, every one in the church in tears, himself outwardly unmoved. ${ }^{1}$ But from that time dates an entire, though always deepening, alteration in his manner of preaching, because an entire change in his way of dealing with God's Word. Not that his abiding religious views and convictions were then originated or even altered-I doubt not that from a child he not only knew the Holy Scriptures, but was 'wise unto salvation'-but it strengthened and clarified, quickened and gave permanent direction to, his sense of God as revealed in His Word. He took as it were to subsoil ploughing; he got a new and adamantine point to the instrument with which he bored, and with a fresh power-with his whole might, he sunk it right down into the living rock, to the virgin gold. His entire nature had got a shock, and his blood was drawn inwards, his surface was chilled; but fuel was heaped all the more on the inner fires, and his zeal, that

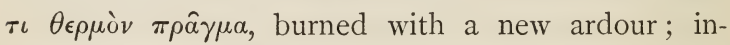
deed had he not found an outlet for his pent-up energy, his brain must have given way, and his

1 I have been told that once in the course of the sermon his voice trembled, and many feared he was about to break down. 


\section{Letter to Fohn Cairns, D.D.}

faculties have either consumed themselves in wild, wasteful splendour and combustion, or dwindled into lethargy. ${ }^{1}$

The manse became silent; we lived and slept and played under the shadow of that death, and we saw, or rather felt, that he was another father than before. No more happy laughter from the two in the parlour, as he was reading Larry the Irish postboy's letter in Miss Edgeworth's tale, or the last Waverley novel ; no more visitings in a cart with her, he riding beside us on his white thorough-bred pony, to Kilbucho, or Rachan Mill, or Kirklawhill. He went among his people as usual when they were ill; he preached better than ever-they were sometimes frightened to think how wonderfully he preached; but the sunshine was over - the glad and careless look, the joy of young life and mutual love. He was little with us, and, as I said, the house was still, except when he was mandating his sermons for Sabbath. This he always did, not only vivâa voce, but with as much energy and loudness as in the pulpit; we

1 There is a story illustrative of this altered manner and matter of preaching. He had been preaching when very young, at Galashiels, and one wife said to her 'neebor,' 'Jean, what think ye o' the lad?' 'It's maist o't tinsel wark,' said Jean, neither relishing nor appreciating his fine sentiments and figures. After my mother's death, he preached in the same place, and Jean, running to her friend, took the first word, 'It's a' gozvd noo.' 
felt his voice was sharper, and rang keen through the house.

What we lost, the congregation and the world gained. He gave himself wholly to his work. As you have yourself said, he changed his entire system and fashion of preaching; from being elegant, rhetorical, and ambitious, he became concentrated, urgent, moving (being himself moved), keen, searching, unswerving, authoritative to fierceness, full of the terrors of the Lord, if he could but persuade men. The truth of the words of God had shone out upon him with an immediateness and infinity of meaning and power, which made them, though the same words he had looked on from childhood, other and greater and deeper words. He then left the ordinary commentators, and men who write about meanings and flutter around the circumference and corners; he was bent on the centre, on touching with his own fingers, on seeing with his own eyes, the pearl of great price. Then it was that he began to dig into the depths, into the primary and auriferous rock of Scripture, and take nothing at another's hand: then he took up with the word 'apprehend;' he had laid hold of the truth, - there it was, with its evidence, in his hand ; and every one who knew him must remember well how, in speaking with earnestness of the meaning of a passage, he, in his ardent, hesitating way, looked into the palm of his hand as if he actually 


\section{Letter to Fohn Cairns, D.D.}

saw there the truth he was going to utter. This word apprehend played a large part in his lectures, as the thing itself did in his processes of investigation, or, if I might make a word, indigation. Comprehension, he said, was for few ; apprehension was for every man who had hands and a head to rule them, and an eye to direct them. Out of this arose one of his deficiencies. He could go largely into the generalities of a subject, and relished greatly others doing it, so that they did do it really and well; but he was averse to abstract and wide reasonings. Principles he rejoiced in : he worked with them as with his choicest weapons ; they were the polished stones for his sling, against the Goliaths of presumption, error, and tyranny in thought or in polity, civil or ecclesiastical; but he somehow divined a principle, or got at it naked and alone, rather than deduced it and brought it to a point from an immensity of particulars, and then rendered it back so as to bind them into one cosmos. One of my young friends, who afterwards went to India, and now dead, used to come and hear him in Broughton Place with me, and this word apprehend caught him, and as he had a great love for my father, in writing home to me, he never forgot to ask how 'grand old Apprehend' was.

From this time dates my father's possession and use of the German Exegetics. After my mother's death I slept with him; his bed was in his study, a 
small room, ${ }^{1}$ with a very small grate; and I remem ber well his getting those fat, shapeless, spongy German books, as if one would sink in them, and be bogged in their bibulous, unsized paper; and watching him as he impatiently cut them up, and dived into them in his rapid, eclectic way, tasting them, and dropping for my play such a lot of soft, large, curled bits from the paper-cutter, leaving the edges all shaggy. He never came to bed when I was awake, which was not to be wondered at; but I can remember often awaking far on in the night or morning, and seeing that keen, beautiful, intense face bending over these Rosenmüllers, and Ernestis, and Storrs, and Kuinoels - the fire out, and the grey dawn peering through the window; and when he heard me move, he would speak to me in the foolish words of endearment my mother was wont to use, and come to bed, and take me, warm as I was, into his cold bosom.

Vitringa in Jesaiam I especially remember, a noble folio. Even then, with that eagerness to communicate what he had himself found, of which you must often have been made the subject, he went and told it. He would try to make me, small man as I was, 'apprehend' what he and Vitringa between them

${ }^{1}$ On a low chest of drawers in this room there lay for many years my mother's parasol, by his orders-I daresay, for long, the only one in Biggar. 
had made out of the fifty-third chapter of his favourite prophet, the princely Isaiah. ${ }^{1}$ Even then, so far as I can recal, he never took notes of what he read. He did not need this, his intellectual force and clearness were so great; he was so totus in illo, whatever it was, that he recorded, by a secret of its own, his

${ }^{1}$ His reading aloud of everything from John Gilpin to John Howe was a fine and high art, or rather gift. Henderson could not have given

'The dinner waits, and we are tired ;'

Says Gilpin, 'So am I,'

better; and to hear him sounding the depths and cadences of the Living Temple, "bearing on its front this doleful inscription, "Here God once dwelt," ' was like listening to the recitative of Handel. But Isaiah was his masterpiece ; and I remember quite well his startling us all when reading at family worship, 'His name shall be called Wonderful, Counsellor, the mighty God,' by a peremptory, explosive sharpness, as of thunder overhead, at the words, 'the mighty God,' similar to the rendering now given to Handel's music, and doubtless so meant by him; and then ciosing with 'the Prince of Peace,' soft and low. No man who wishes to feel Isaiah, as well as understand him, should be ignorant of Handel's 'Messiah.' His prelude to 'Comfort ye '-its simple theme, cheerful and infinite as the ripple of the unsearchable sea-gives a deeper meaning to the words. One of my father's great delights in his dying months was reading the lives of Handel and Michael Angelo, then newly out. He felt that the author of 'He was despised,' and ' $\mathrm{He}$ shall feed his flock,' and those other wonderful airs, was a man of profound religious feeling, of which they were the utterance; and he rejoiced over the warlike airs and choruses of 'Judas Maccabæus.' You have recorded his estimate of the religious nature of him of the terribile via: he said it was a relief to his mind to know that such a mighty genius walked humbly with his God. 
mind's results and victories and memoranda, as he went on; he did not even mark his books, at least very seldom; he marked his mind.

He was thus every year preaching with more and more power, because with more and more knowledge and 'pureness ;' and, as you say, there were probably nowhere in Britain such lectures delivered at that time to such an audience, consisting of country people, sound, devout, well-read in their Bibles and in the native divinity, but quite unused to persistent, deep, critical thought.

Much of this-most of it-was entirely his own, self-originated and self-sustained, and done for its own sake,

'All too happy in the pleasure

Of his own exceeding treasure.'

But he often said, with deep feeling, that one thing put him always on his mettle, the knowledge that "yonder in that corner, under the gallery, sat, Sabbath after Sabbath, a man who knew his Greek Testament better than I did.'

This was his brother-in-law, and one of his elders, Mr. Robert Johnston, married to his sister Violet, a merchant and portioner in Biggar, a remarkable man, of whom it is difficult to say to strangers what is true, without being accused of exaggeration. A shopkeeper in that remote little town, he not only intermeddled fearlessly with all knowledge, but mastered more than 


\section{Letter to Fohn Cairns, D.D.}

many practised and University men do in their own lines. Mathematics, astronomy, and especially what may be called selenology, or the doctrine of the moon, and the higher geometry and physics; Hebrew, Sanscrit, Greek, and Latin, to the veriest rigours of prosody and metre; Spanish and Italian, German, French, and any odd language that came in his way; all these he knew more or less thoroughly, and acquired them in the most leisurely, easy, cool sort of a way, as if he grazed and browsed perpetually in the field of letters, rather than made formal meals, or gathered for any ulterior purpose, his fruits, his roots, and his nuts-he especially liked mental nuts-much less bought them from any one.

With all this, his knowledge of human, and especially of Biggar human nature, the ins and outs of its little secret ongoings, the entire gossip of the place, was like a woman's ; moreover, every personage great or small, heroic or comic, in Homer-whose poems he made it a matter of conscience to read once every four years-Plautus, Suetonius, Plutarch, Tacitus, and Lucian, down through Boccaccio and Don Quixote, which he knew by heart and from the living Spanish, to Joseph Andrews, the Spectator, Goldsmith and Swift, Miss Austen, Miss Edgeworth, and Miss Ferrier, Galt and Sir Walter-he was as familiar with as with David Crockat the nailer, or the parish minister, the town-drummer, the mole-catcher, or the poaching 
weaver, who had the night before leistered a prime kipper at Rachan Mill, by the flare of a tarry wisp, or brought home his surreptitious grey hen or maukin from the wilds of Dunsyre or the dreary Lang Whang. ${ }^{1}$

This singular man came to the manse every Friday evening for many years, and he and my father discussed everything and everybody;--beginning with tough, strong head work-a bout at wrestling, be it Cæsar's Bridge, the Epistles of Phalaris, the import of $\mu^{\prime} \boldsymbol{\epsilon}^{\prime}$ and $\delta \epsilon$, the Catholic question, or the great roots of Christian faith; ending with the latest joke in the town or the West Raw, the last effusion by Affleck, tailor and poet, the last blunder of Assop the apothecary, and the last repartee of the village fool, with the week's Edinburgh and Glasgow news by their respective carriers; the whole little life, sad and humorouswho had been born, and who was dying or dead, married or about to be, for the past eight days. ${ }^{2}$

This amused, and, in the true sense, diverted my father, and gratified his curiosity, which was great,

1 With the practices of this last worthy, when carried on moderately, and for the sport's sake, he had a special sympathy.

${ }^{2}$ I believe this was the true though secret source of much of my father's knowledge of the minute personal history of every one in his region, which-to his people, knowing his reserved man ner and his devotion to his studies, and his so rarely meeting them or speaking to them, except from the pulpit, or at a diet of visitation - was a perpetual wonder, and of which he made great use in his dealings with his afflicted or erring ' members.' 
and his love of men as well as for man. He was shy, and unwilling to ask what he longed to know, liking better to have it given him without the asking; and no one could do this better than 'Uncle Johnston.'

You may readily understand what a thorough exercise and diversion of an intellectual and social kind this was, for they were neither of them men to shirk from close gripes, or trifle and flourish with their weapons ; they laid on and spared not. And then my uncle had generally some special nut of his own to crack, some thesis to fling down and offer battle on, some 'particle' to energize upon; for though quiet and calm, he was thoroughly combative, and enjoyed seeing his friend's blood up, and hearing his emphatic and bright speech, and watching his flashing eye. Then he never spared him; criticised and sometimes quizzed-for he had great humour-his style, as well as debated and weighed his apprehendings and exegeses, shaking them heartily to test their strength. He was so thoroughly independent of all authority, except that of reason and truth, and his own humour; so ready to detect what was weak, extravagant, or unfair; so full of relish for intellectual power and accuracy, and so attached to and proud of my father, and bent on his making the best of himself, that this trial was never relaxed. His firm and close-grained mind was a sort of whetstone on which my father sharpened his wits at this weekly 'setting.' 
The very difference of their mental tempers and complexions drew them together-the one impatient, nervous, earnest, instant, swift, vehement, regardless of exertion, bent on his goal, like a thorough-bred racer, pressing to the mark; the other leisurely to slowness and provokingness, with a constitution which could stand a great deal of ease, unimpassioned, still, clear, untroubled by likings or dislikings, dwelling and working in thought and speculation and observation as ends in themselves, and as their own rewards : ${ }^{1}$ the one hunting for a principle or a ' divine method;' the other sapping or shelling from a distance, and for his pleasure, a position, or gaining a point, or settling a rule, or verifying a problem, or getting axiomatic and proverbial.

In appearance they were as curiously unlike; my

${ }^{1}$ He was curiously destitute of all literary ambition or show ; like the cactus in the desert, always plump, always taking in the dew of heaven, and caring little to give it out. He wrote many papers in the Repository and Monitor, an acute and clever tract on the Voluntary controversy, entitled Calm Answers to Angry Questions, and was the author of a capital bit of literary banter-a Congratulatory Letter to the Minister of Liberton, who had come down upon my father in a pamphlet, for his sermon on 'There remaineth much land to be possessed.' It is a mixture of Swift and Arbuthnot. I remember one of the flowers he culls from him he is congratulating, in which my father is characterized as one of those "shallow, sallow souls that would swallow the bait, without perceiving the cloven foot!' But a man like this never is best in a book; he is always greater than his work. 
uncle short and round to rotundity, homely and florid in feature. I used to think Socrates must have been like him in visage as well as in much of his mind. He was careless in his dress, his hands in his pockets as a rule, and strenuous only in smoking or in sleep : with a large, full skull, a humorous twinkle in his cold, blue eye, a soft, low voice, expressing every kind of thought in the same, sometimes plaguily douce tone; a great power of quiet and telling sarcasm, large capacity of listening to and of enjoying other men's talk, however small.

My father - tall, slim, agile, quick in his movements, graceful, neat to nicety in his dress, with much in his air of what is called style, with a face almost too beautiful for a man's, had not his eyes commanded it and all who looked at it, and his close, firm mouth been ready to say what the fiery spirit might bid; his eyes, when at rest, expressing -more than almost any other I ever saw-sorrow and tender love, a desire to give and to get sympathy, and a sort of gentle, deep sadness, as if that was their permanent state, and gladness their momentary act; but when awakened, full of fire, peremptory, and not to be trifled with; and his smile, and flash of gaiety and fun, something no one could forget; his hair in early life a dead black; his eyebrows of exquisite curve, narrow and intense; his voice deep when unmoved and calm; keen and 
sharp to piercing fierceness when vehement and roused - in the pulpit, at times a shout, at times a pathetic wail ; his utterance hesitating, emphatic, explosive, powerful, — each sentence shot straight and home; his hesitation arising from his crowd of impatient ideas, and his resolute will that they should come in their order, and some of them not come at all, only the best, and his settled determination that each thought should be dressed in the very and only word which he stammered on till it came,-it was generally worth his pains and ours.

Uncle Johnston, again, flowed on like Cæsar's Arar, incredibili lenitate, or like linseed out of a poke. You can easily fancy the spiritual and bodily contrast of these men, and can fancy too, the kind of engagements they would have with their own proper weapons on these Friday evenings, in the old manse dining-room, my father showing uncle out into the darkness of the back-road, and uncle, doubtless, lighting his black and ruminative pipe.

If my uncle brought up nuts to crack, my father was sure to have some difficulties to consult about, or some passages to read, something that made him put his whole energy forth; and when he did so, I never heard such reading. To hear him read the story of Joseph, or passages in David's history, and Psalms 6th, IIth, and 15 th, or the $52 \mathrm{~d}, 53 \mathrm{~d}, 54$ th, $55^{\text {th }}, 63 \mathrm{~d}, 64$ th, and 4 oth chapters of Isaiah, or the 


\section{Letter to Fohn Cairns, D.D.}

Sermon on the Mount, or the Journey to Emmaus, or our Saviour's prayer in John, or Paul's speech on Mars Hill, or the first three chapters of Hebrews and the latter part of the IIth, or Job, or the Apocalypse ; or to pass from those divine themes-Jeremy Taylor, or George Herbert, Sir Walter Raleigh, or Milton's prose, such as the passage beginning, 'Come forth out of thy royal chambers, $\mathrm{O}$ thou Prince of all the kings of the earth!' and 'Truth, indeed, came once into the world with her divine Master,' or Charles Wesley's Hymns, or, most loved of all, Cowper, from the rapt 'Come thou, and, added to thy many crowns,' or ' $\mathrm{O}$ that those lips had language !' to the Jackdaw, and his incomparable Letters ; or Gray's Poems, Burns's 'Tam O'Shanter,' or Sir Walter's 'Eve of St. John,' ${ }^{1}$ and 'The Grey Brother.'

But I beg your pardon: Time has run back with me, and fetched that blessed past, and awakened its echoes. I hear his voice; I feel his eye; I see his

1 Well do I remember when driving him from Melrose to Kelso, long ago, we came near Sandyknowe, that grim tower of Smailholm, standing erect like a warder turned to stone, defying time and change, his bursting into that noble ballad-

\footnotetext{
' The Baron of Smaylho'me rose with day,

He spurr'd his courser on,

Without stop or stay, down the rocky way,

That leads to Brotherstone ;'
}

and pointing out the 'Watchfold height,' 'the eiry Beacon Hill,' and 'Brotherstone.' 
whole nature given up to what he is reading, and making its very soul speak.

Such a man then as I have sketched, or washed faintly in, as the painters say, was that person who sat in the corner under the gallery every Sabbathday, and who knew his Greek Testament better than his minister. He is dead, too, a few months ago, dying surrounded with his cherished hoard of books of all sizes, times, and tongues - tatterdemalion many; all however drawn up in an order of his own; all thoroughly mastered and known; among them David Hume's copy of Shaftesbury's Characteristics, with his autograph, which he had picked up at some stall.

I. have said that my mother's death was the second epoch in my father's life. I should perhaps have said the third; the first being his mother's long illness and

- death, and the second his going to Elie, and beginning the battle of life at fifteen. There must have been something very delicate and close and exquisite in the relation between the ailing, silent, beautiful and pensive mother, and that dark-eyed, dark-haired, bright and silent son; a sort of communion it is not easy to express. You can think of him at eleven slowly writing out that small book of promises in a distinct and minute hand, quite as like his mature hand, as the shy, lustrous-eyed boy was to his after self in his manly years, and sitting by the bedside while the rest were out and shouting, playing at hide- 


\section{Letter to Fohn Cairns, D.D.}

and-seek round the little church, with the winds from Benlomond or the wild uplands of Ayrshire blowing through their hair. He played seldom, but when he did run out, he jumped higher and farther, and ran faster than any of them. His peculiar beauty must have come from his mother. He used at rare times, and with a sort of shudder, to tell of her when a lovely girl of fifteen, having been seen by a gentleman of rank, in Cheapside, hand in hand with an evil woman, who was decoying her to ruin, on pretence of showing her the way home; and how he stopped his carriage, and taking in the unconscious girl, drove her to her uncle's door. But you have said all this better than I can.

His time with his mother, and the necessary confinement and bodily depression caused by it, I doubt not deepened his native thoughtful turn, and his ten- ${ }^{\bullet}$ dency to meditative melancholy, as a condition under which he viewed all things, and quickened and intensified his sense of the suffering of this world, and of the profound seriousness and mystery in the midst of which we live and die.

The second epoch was that of his leaving home with his guinea, the last he ever got from any one but himself; and his going among utter strangers to be master of a school one half of the scholars of which were bigger and older than himself, and all rough colts-wilful and unbroken. This was his first 
fronting of the world. Besides supporting himself, this knit the sinews of his mind, and made him rely on himself in action as well as in thought. He sometimes, but not often, spoke of this, never lightly, though he laughed at some of his predicaments. $\mathrm{He}$ could not forget the rude shock. Generally those familiar revelations were at supper, on the Sabbath evening, when, his work over, he enjoyed and lingered over his meal.

From his young and slight, almost girlish look, and his refined, quiet manners, the boys of the school were inclined to annoy and bully him. He saw this, and felt it was now or never,-nothing between. So he took his line. The biggest boy, much older and stronger, was the rudest, and infected the rest. The ' wee maister' ordered him, in that peremptory voice we all remember, to stand up and hold out his hand, being not at all sure but the big fellow might knock him down on the word. To the astonishment of the school, and to the big rebel's too, he obeyed and was punished on the instant, and to the full; out went the hand, down came the 'taws,' and bit like fire. From that moment he ruled them by his eye, the taws vanished.

There was an incident at this time of his life which I should perhaps not tell, and yet I don't know why I shouldn't, it so perfectly illustrates his character in many ways. He had come home during the vacation 


\section{Letter to Fohn Cairns, D.D.}

of his school to Langrig, and was about to go back; he had been renewing his intercourse with his old teacher and friend whom you mention, from whom he used to say he learned to like Shakspere, and who seems to have been a man of genuine literary tastes. He went down to bid him good-bye, and doubtless they got on their old book loves, and would be spouting their pet pieces. The old dominie said, 'John, my man, if you are walking into Edinburgh, I'll convoy you a bit.' 'John' was too happy, so next morning they set off, keeping up a constant fire of quotation and eager talk. They got past Mid-Calder to near East, when my father insisted on his friend returning, and also on going back a bit with him; on looking at the old man, he thought he was tired, so on reaching the well-known 'Kippen's Inn,' he stopped and insisted on giving him some refreshment. Instead of ordering bread and cheese and a bottle of ale, he, doubtless full of Shakspere, and great upon sack and canary, ordered a bottle of wine! Of this, you may be sure, the dominie, as he most needed it, had the greater share, and doubtless it warmed the cockles of his old heart. 'John' making him finish the bottle, and drink the health of 'Gentle Will,' saw him off, and went in to pay the reckoning. What did he know of the price of wine! It took exactly every penny he had; I doubt not, most boys, knowing that the landlord knew them, would have either 
paid a part, or asked him to score it up. This was not his way; he was too proud and shy and honest for such an expedient. By this time, what with discussing Shakspere, and witnessing his master's leisurely emptying of that bottle, and releasing the

'Dear prisoned spirits of the impassioned grape,'

he found he must run for it to Edinburgh, or rather Leith, fourteen miles; this he did, and was at the pier just in time to jump into the Elie pinnace, which was already off. $\mathrm{He}$ often wondered what he would have done if he had been that one moment late. You can easily pick out the qualities this story unfolds.

His nature, capable as it was of great, persistent, and indeed dogged labour, was, from the predominance of the nervous system in his organization, excitable, and therefore needed and relished excitement-the more intense the better. He found this in his keen political tastes, in imaginative literature, and in fiction. In the highest kind of poetry he enjoyed the sweet pain of tears; and he all his life had a steady liking, even a hunger, for a good novel. This refreshed, lightened, and diverted his mind from the strain of his incessant exegesis. He used always to say that Sir Walter and Goldsmith, and even Fielding, Miss Edgeworth, Miss Austen, and Miss Ferrier, were true benefactors to the race, by 


\section{Letter to Fohn Cairns, D.D.}

giving such genuine, such secure and innocent pleasure : and he often repeated with admiration Lord Jeffrey's words on Scott, inscribed on his monument. He had no turn for gardening or for fishing or any field sports or games; his sensitive nature recoiled from the idea of pain, and above all, needless pain. He used to say the lower creation had groans enough, and needed no more burdens; indeed, he was fierce to some measure of unfairness against such of his brethren-Dr. Wardlaw, for instance ${ }^{1}$ - as resembled the apostles in fishing for other things besides men.

But the exercise and the excitement he most of all others delighted in, was riding; and had he been a country gentleman and not a clergyman, I don't think he could have resisted fox-hunting. With the exception of that great genius in more than horsemanship, Andrew Ducrow, I never saw a man sit a horse as he did. He seemed inspired, gay, erect, full of the joy of life, fearless and secure. I have heard a farmer friend say if he had not been a preacher of the gospel he would have been a cavalry officer, and would have fought as he preached.

He was known all over the Upper Ward and down Tweeddale for his riding. ' There goes the minister,' as he rode past at a swift canter. He had generally

1 After a tight discussion between these two attached friends, Dr. Wardlaw said, 'Well, I can't answer you, but fish I must and shall.' 
well-bred horses, or as I would now call them, ponies; if he had not, his sufferings from a dull, hardmouthed, heavy-hearted and footed plebeian horse were almost comic. On his grey mare, or his little blood bay horse, to see him setting off and indulging it and himself in some alarming gambols, and in the midst of his difficulties, partly of his own making, taking off his hat or kissing his hand to a lady, made one think of 'young Harry with his beaver up.' He used to tell with much relish, how, one fine summer Sabbath evening, after preaching in the open air for a collection, in some village near, and having put the money, chiefly halfpence, into his handkerchief, and that into his hat, he was taking a smart gallop home across the moor, happy and relieved, when three ladies-I think, the Miss Bertrams of Kersewell-came suddenly upon him; off went the hat, down bent the head, and over him streamed the cherished collection, the ladies busy among the wild grass and heather picking it up, and he full of droll confusion and laughter.

The grey mare he had for many years. I can remember her small head and large eyes; her neat, compact body, round as a barrel; her finely fleabitten skin, and her thoroughbred legs. I have no doubt she had Arabian blood. My father's pride in her was quite curious. Many a wild ride to and from the Presbytery at Lanark, and across flooded and shifting fords, he had on her. She was as sweet- 


\section{Letter to Fohn Cairns, D.D.}

tempered and enduring, as she was swift and sure; and her powers of running were appreciated and applied in a way which he was both angry and amused to discover. You know what riding the bruse means. At a country wedding the young men have a race to the bridegroom's home, and he who wins, brings out a bottle and glass and drinks the young wife's health. I wish Burns had described a bruse; all sorts of steeds, wild, unkempt lads as well as colts, old broken-down thoroughbreds that did wonders when soopled, huge, grave cart-horses devouring the road with their shaggy hoofs, wilful ponies, etc. You can imagine the wild hurry-skurry and fun, the comic situations and upsets over a rough road, up and down places one would be giddy to look at.

Well, the young farmers were in the habit of coming to my father, and asking the loan of the mare to go and see a friend, etc., etc., praising knowingly the fine points and virtues of his darling. Having through life, with all his firmness of nature, an abhorrence of saying 'No' to any one, the interview generally ended with, 'Well, Robert, you may have her, but take care of her, and don't ride her fast.' In an hour or two Robert was riding the bruse, and flying away from the crowd, Grey first, and the rest nowhere, and might be seen turning the corner of the farm-house with the victorious bottle in his uplifted hand, the motley pack panting vainly up the hill. 
This went on for long, and the grey was famous, almost notorious, all over the Upper Ward; sometimes if she appeared, no one would start, and she trotted the course. Partly from his own personal abstraction from outward country life, and partly from Uncle Johnston's sense of waggery keeping him from telling his friend of the grey's last exploit at Hartree Mill, or her leaping over the 'best man' at Thriepland, my father was the last to hear of this equivocal glory of 'the minister's meer.' Indeed, it was whispered she had once won a whip at Lanark races. They still tell of his feats on this fine creature, one of which he himself never alluded to without a feeling of shame. $\mathrm{He}$ had an engagement to preach somewhere beyond the Clyde on a Sabbath evening, and his excellent and attached friend and elder, Mr. Kello of Lindsaylands, accompanied him on his big plough horse. It was to be in the open air, on the river side. When they got to the Clyde they found it in full flood, heavy and sudden rains at the head of the water having brought it down in a wild spate. On the opposite side were the gathered people and the tent. Before Mr. Kello knew where he was, there was his minister on the mare swimming across, and carried down in a long diagonal, the people looking on in terror. He landed, shook himself, and preached with his usual fervour. As I have said, he never liked to speak of this bit of hardihood, 


\section{Letter to Fohn Cairns, D.D.}

and he never repeated it ; but it was like the manthere were the people, that was what he would be at, and though timid for anticipated danger as any woman, in it he was without fear.

One more illustration of his character in connexion with his riding. On coming to Edinburgh he gave up this kind of exercise; he had no occasion for it, and he had enough and more than enough of excitement in the public questions in which he found himself involved, and in the miscellaneous activities of a popular town minister. I was then a young doctor -it must have been about 1840 -and had a patient, Mrs. James Robertson, eldest daughter of Mr. Pirie, the predecessor of Dr. Dick in what was then Shuttle Street congregation, Glasgow. She was one of my father's earliest and dearest friends, - a mother in the Burgher Israel, she and her cordial husband 'given to hospitality,' especially to 'the Prophets.' She was hopelessly ill at Juniper Green, near Edinburgh. Mr. George Stone, then living at Muirhouse, one of my father's congregation in 'Broughton Place, a man of equal originality and worth, and devoted to his minister, knowing my love of riding, offered me his blood-chestnut to ride out and make my visit. $\mathrm{My}$ father said, 'John, if you are going, I would like to ride out with you ;' he wished to see his dying friend. 'You ride!' said Mr. Stone, who was a very Yorkshireman in the matter of horses. 'Let 
him try,' said I. 'The upshot was, that Mr. Stone sent the chestnut for me, and a sedate pony-called, if I forget not, Goliath-for his minister, with all sorts of injunctions to me to keep him off the thoroughbred, and on Goliath.

My father had not been on a horse for nearly twenty years. He mounted and rode off. He soon got teased with the short, pattering steps of Goliath, and looked wistfully up at me, and longingly to the tall chestnut, stepping once for Goliath's twice, like the Don striding beside Sancho. I saw what he was after, and when past the toll he said in a mild sort of way, 'John, did you promise absolutely I was not to ride your horse?' 'No, father, certanly not. Mr. Stone, I daresay, wished me to do so, but I didn't.' 'Well, then, I think we'll change ; this beast shakes me.' So we changed. I remember how noble he looked; how at home : his white hair and his dark eyes, his erect, easy, accustomed seat. He soon let his eager horse slip gently away. It was first evasit, he was off, Goliath and I jogging on behind; then erupit, and in a twinkling-evanuit. I saw them last flashing through the arch under the Canal, his white hair flying. I was uneasy, though from his riding I knew he was as yet in command, so I put Goliath to his best, and having passed through Slateford, I asked a stonebreaker if he saw a gentleman on a chestnut horse. 'Has he white hair?' 'Yes.' 


\section{Letter to Fohn Cairns, D.D.}

'And een like a gled's?' 'Yes.' 'Weel, then, he's fleein' up the road like the wund; he'll be at Little Vantage' (about nine miles off) ' in nae time if he haud on.' I never once sighted him, but on coming into Juniper Green there was his steaming chestnut at the gate, neighing cheerily to Goliath. I went in, he was at the bedside of his friend, and in the midst of prayer; his words as I entered were, "When thou passest through the waters I will be with thee, and through the rivers, they shall not overflow thee ;' and he was not the less instant in prayer that his blood was up with his ride. He never again saw Mrs. Robertson, or as she was called when they were young, Sibbie (Sibella) Pirie. On coming out he said nothing, but took the chestnut, mounted her, and we came home quietly. His heart was opened; he spoke of old times and old friends ; he stopped at the exquisite view at Hailes into the valley, and up the Pentlands beyond, the smoke of Kate's Mill rising in the still and shadowy air, and broke out into Cowper's words : Yes,

' $\mathrm{HE}$ sets the bright procession on its way, And marshals all the order of the year;

And ere one flowery season fades and dies, Designs the blooming wonders of the next.'

Then as we came slowly in, the moon shone behind Craiglockhart hill among the old Scotch firs; he pulled up again, and gave me Collins' Ode to Evening, beginning- 
- If aught of oaten stop, or pastoral song, May hope, chaste Eve, to soothe thy modest ear, Thy springs, and dying gales ;' repeating over and over some of the lines, as

'Thy modest ear, Thy springs, and dying gales.'

'-And marks o'er all Thy dewy fingers draw The gradual dusky veil.'

And when she looked out on us clear and full, 'Yes-

' The moon takes up the wondrous tale, And nightly to the listening earth Repeats the story of her birth.'

As we passed through Slateford, he spoke of Dr. Belfrage, his great-hearted friend, of his obligations to him, and of his son, my friend, both lying together in Colinton churchyard; and of Dr. Dick, who was minister before him, of the Coventrys, and of Stitchel and Sprouston, of his mother, and of himself,-his doubts of his own sincerity in religion, his sense of sin, of God - reverting often to his dying friend. Such a thing only occurred to me with him once or twice all my life; and then when we were home, he was silent, shut up, self-contained as before. He was himself conscious of this habit of reticence, and what may be called selfism to us, his children, and lamented it. I remember his saying in a sort of mournful joke, ' $I$ have a well of love; I know it; but it is a well, and a draw-well, 


\section{Letter to Fohn Cairns, D.D.}

to your sorrow and mine, and it seldom overflows, but,' looking with that strange power of tenderness as if he put his voice and his heart into his eyes, 'you may always come hither to draw ;' he used to say he might take to himself Wordsworth's lines-

'I am not one who much or oft delights

To season my fireside with personal talk.'

And changing 'though' into 'if :'

'A well of love it may be deep,

I trust it is, and never dry ;

What matter, though its waters sleep

In silence and obscurity?'

The expression of his affection was more like the shock of a Leyden jar, than the continuous current of a galvanic circle.

There was, as I have said, a permanent chill given by my mother's death, to what may be called the outer surface of his nature, and we at home felt it much. The blood was thrown in upon the centre, and went forth in energetic and victorious work, in searching the Scriptures and saving souls; but his social faculty never recovered that shock! it was blighted; he was always desiring to be alone and at his work. A stranger who saw him for a short time, bright, animated, full of earnest and cordial talk, pleasing and being pleased, the life of the company, was apt to think how delightful he must always be,- - and so he was; but these times of bright talk were like angels' visits; and he smiled with peculiar 
benignity on his retiring guest, as if blessing him not the less for leaving him to himself. I question if there ever lived a man so much in the midst of men, and in the midst of his own children, ${ }^{1}$ in whom the silences, as Mr. Carlyle would say, were so predominant. Every Sabbath he spoke out of the abundance of his heart, his whole mind; he was then communicative and frank enough : all the week, before and after, he would not unwillingly have never opened his mouth. Of many people we may say that their-mouth is always open except when it is shut; of him that his mouth was always shut except when it was opened. Every one must have been struck with the seeming inconsistency of his occasional brilliant, happy, energetic talk, and his habitual silentness-his difficulty in getting anything to say. But, as I have already said, what we lost, the world and the church gained.

When travelling he was always in high spirits and full of anecdote and fun. Indeed I knew more of his inner history in this one way, than during years of living with him. I recollect his taking me with him to Glasgow when I must have been about fourteen; we breakfasted in The Ram's Horn Tavern, and I felt a new respect for him at his commanding the waiters. He talked a great deal during our short tour, and often have I desired to recal the many

${ }^{1}$ He gave us all the education we got at Biggar. 


\section{Letter to Fohn Cairns, D.D.}

things he told me of his early life, and of his own religious crises, my mother's death, his fear of his own death, and all this intermingled with the drollest stories of his boy and student life.

We went to Paisley and dined, I well remember, we two alone, and, as I thought, magnificently, in a great apartment in The Saracen's Head, at the end of which was the county ballroom. We had come across from Dunoon and landed in a small boat at the Water $\mathrm{Neb}$ along with Mrs. Dr. Hall, a character Sir Walter or Galt would have made immortal. My father with characteristic ardour took an oar, for the first time in his life, and I believe for the last, to help the old boatman on the Cart, and wishing to do something decided, missed the water, and went back head over heels to the immense enjoyment of Mrs. Hall, who said, 'Less pith, and mair to the purpose, my man.' She didn't let the joke die out.

Another time-it was when his second marriage was fixed on, to our great happiness and his-I had just taken my degree of M.D., and he took Isabella, William, and myself to Moffat. By a curious felicity we got into Miss Geddes' lodgings, where the village circulating library was kept, the whole of which we aver he read in ten days. I never saw him so happy, so open and full of mirth, reading to us, and reciting the poetry of his youth. On these rare but delightful occasions he was fond of exhibiting, when asked, his 
powers of rapid speaking, in which he might have rivalled old Matthews or his son. His favourite feat was repeating 'Says I to my Lord, quo' I-what for will ye no grund ma barleymeal mouter-free, says I to my Lord, quo' I, says I, I says.' He was brilliant upon the final 'I says.' Another chef-d' cuvre was, 'On Tintock tap there is a mist, and in the mist there is a kist (a chest), and in the kist there is a cap (a wooden bowl), and in the cap there is a drap, tak' up the cap, and sup the drap, and set the cap on Tintock tap.' This he could say, if I mistake not, five times without drawing breath. It was a favourite passage this, and he often threatened to treat it exegetically; laughing heartily when I said, in that case, he would not have great trouble with the context, which in others cost him a good deal.

His manners to ladies, and indeed to all women, were those of a courtly gentleman; they could be romantic in their empressement and devotion, and I used to think Sir Philip Sydney, or Ariosto's knights and the Paladins of old, must have looked and moved as he did. He had great pleasure in the company of high-bred, refined, thoughtful women; and he had a peculiar sympathy with the sufferings, the necessary mournfulness of women, and with all in their lot connected with the fruit of that forbidden tree-their loneliness, the sorrows of their time, and their pangs in travail, their peculiar relation to their children. I 


\section{Letter to Fohn Cairns, D.D.}

think I hear him reading the words, 'Can a woman forget her sucking child, that she should not have compassion on the son of her womb? Yea' (as if it was the next thing to impossible), 'she may forget, yet will not I forget thee.' Indeed, to a mar who saw so little of, and said so little to his own children, perhaps it may be because of all this, his sympathy for mothers under loss of children, his real suffering for their suffering, not only endeared him to them as their minister, their consoler, and gave him opportunities of dropping in divine and saving truth and comfort, when the heart was full and soft, tender, and at his mercy, but it brought out in his only loss of this kind; the mingled depth, tenderness, and also the peremptoriness of his nature.

In the case of the death of little Maggie-a child the very image of himself in face, lovely and pensive, and yet ready for any fun, with a keenness of affection that perilled everything on being loved, who must cling to some one and be clasped, made for a garden, for the first garden, not for the rough world, the child of his old age-this peculiar meeting of opposites was very marked. She was stricken with sudden illness, malignant sore throat; her mother was gone, and so she was to my father as a flower he had the sole keeping of ; and his joy in her wild mirth, his watching her childish moods of sadness, as if a shadow came over her young heaven, were them- 
selves something to watch. Her delicate life made no struggle with disease; it as it were declined to stay on such conditions. She therefore sunk at once and without much pain, her soul quick and unclouded, and her little forefinger playing to the last with my father's silvery curls, her eyes trying in vain to brighten his :-

'Thou wert a dew-drop which the morn brings forth,

Not fitted to be trailed along the soiling earth ;

But at the touch of wrong, without a strife,

Slips in a moment out of life.'

His distress, his anguish at this stroke, was not only intense, it was in its essence permanent; he went mourning and looking for her all his days; but after she was dead, that resolved will compacted him in an instant. It was on a Sabbath morning she died, and he was all day at church, not many yards from where lay her little corpse alone in the house. His colleague preached in the forenoon, and in the afternoon he took his turn, saying before beginning his discourse :- 'It has pleased the Father of Lights to darken one of the lights of my dwelling-had the child lived I would have remained with her, but now I have thought it right to arise and come into the house of the Lord to worship.' Such violence to one part of his nature by that in it which was supreme, injured him : it was like pulling up on the instant an express train; the whole inner organization is mi- 


\section{Letter to Fohn Caims, D.D.}

nutely, though it may be invisibly hurt ; its molecular constitution damaged by the cruel stress and strain. Such things are not right; they are a cruelty and injustice and injury from the soul to the body, its faithful slave, and they bring down, as in his case they too truly did, their own certain and specific retribution. A man who did not feel keenly might have preached; a man whose whole nature was torn, shattered, and astonished as his was, had in a high sense no right so to use himself; and when too late he opened his eyes to this. It was part of our old Scottish severe unsparing character-calm to coldness outside, burning to fierceness, tender to agony within.

I was saying how much my father enjoyed women's company. He liked to look on them, and watch them, listening ${ }^{1}$ to their keen, unconnected, and unreasoning, but not unreasonable talk. Men's argument, or rather arguing, and above all debating, he disliked. He had no turn for it. He was not

${ }^{1}$ One day my mother, and her only sister, Agnes-married to James Aitken of Callands, a man before his class and his time, for long the only Whig and Seceder laird in Peeblesshire, and with whom my father shared the Edinburgh Review from its beginning - the two sisters who were, the one to the other, as Martha was to Mary, sat talking of their household doings ; my aunt was great upon some things she could do; my father looked up from his book, and said, 'There is one thing, Mrs. Aitken, you cannot do-you cannot turn the heel of a stocking :' and he was right, he had noticed her make over this 'kittle' turn to her mother. 
combative, much less contentious. He was, however, warlike. Anything that he could destroy, any falsehood or injustice, he made for, not to discuss, but to expose and kill. He could not fence with his mind much less with his tongue, and had no love for the exploits of a nimble dialectic. He had no readiness either in thought or word for this; his way was slowly to think out a subject, to get it well 'bottomed,' as Locke would say; he was not careful as to recording the steps he took in their order, but the spirit of his mind was logical, as must be that of all minds who seek and find truth, for logic is nothing else than the arithmetic of thought; having therefore thought it out, he proceeded to put it into formal expression. This he did so as never again to undo it. His mind seemed to want the wheels by which this is done, vestigia mulla retrorsum, and having stereotyped it, he was never weary of it ; it never lost its life and freshness to him, and he delivered it as emphatically thirty years after it had been cast, as the first hour of its existence.

I have said he was no swordsman, but he was a heavy shot; he fired off his ball, compact, weighty, the maximum of substance in the minimum of bulk; he put in double charge, pointed the muzzle, and fired, with what force and sharpness we all remember. If it hit, good; if not, all he could do was to load again, with the same ball, and in the same direc- 


\section{Letter to Fohn Cairns, D.D.}

tion. You must come to him to be shot, at least you must stand still, for he had a want of mobility of mind in great questions. He could not stalk about the field like a sharp-shooter; his was a great sixtyeight pounder, and it was not much of a swivel. Thus it was that he rather dropped into the minds of others his authoritative assertions, and left them to breed conviction. If they gave them entrance and cherished them, they would soon find how full of primary truth they were, and how well they would serve them, as they had served him. With all this heavy artillery, somewhat slow and cumbrous, on great questions, he had no want, when he was speaking off-hand, of quick snell remark, often witty and full of spirit, and often too unexpected, like lightningflashing, smiting and gone. In Church Courts this was very marked. On small ordinary matters, a word from him would settle a long discussion. He would, after lively, easy talk with his next neighbour, set him up to make a speech, which was conclusive. But on great questions he must move forward his great gun with much solemnity and effort, partly from his desire to say as much of the truth at once as he could, partly from the natural concentration and rapidity of his mind in action, as distinguished from his slowness when incubating, or in the process of thought, - and partly from a sort of self-consciousness -I might almost call it a compound of pride and 
nervous diffidence-which seldom left him. He desired to say it so that it might never need to be said again or otherwise by himself, or any one else.

This strong personality, along with a prevailing love to be alone, and dwell with thoughts rather than with thinkers, pervaded his entire character. His religion was deeply personal, ${ }^{1}$ not only as affecting himself, but as due to a personal God, and presented through the sacrifice and intercession of the God-man; and it was perhaps owing to his 'conversation' being so habitually in heaven-his social and affectionate desires filling themselves continually from ' all the fulness of God,' through living faith and love-that he the less felt the need of giving and receiving human affection. I never knew any man who lived more truly under the power, and sometimes under the shadow of the world to come. This world had to him little reality except as leading to the next; little interest, except as the time of probation and sentence. A child brought to him to be baptized was in his mind, and in his words, 'a young immortal to be educated for eternity;' a birth was the beginning of what was never to end; sin-his own and that of the race-was to him, as it must be to all men who can think, the great mystery, as it is the main curse of

${ }^{1}$ In his own words, 'A personal Deity is the soul of Natural Religion; a personal Saviour-the real living Christ-is the soul of Revealed Religion.' 


\section{Letter to Fohn Cairns, D.D.}

time. The idea of it - of its exceeding sinfulnesshaunted and oppressed him. He used to say of John Foster, that this deep and intense, but sometimes narrow and grim thinker, had, in his study of the disease of the race, been, as it were, fascinated by its awful spell, so as almost to forget the remedy. This was not the case with himself. As you know, no man held more firmly to the objective reality of his religion - that it was founded upon fact. It was not the polestar he lost sight of, or the compass he mistrusted; it was the sea-worthiness of the vessel. His constitutional deficiency of hope, his sensibility to sin, made him not unfrequently stand in doubt of himself, of his sincerity and safety before God, and sometimes made existence- the being obliged to continue to be -a doubtful privilege.

When oppressed with this feeling,-—'the burden and the mystery of all this unintelligible world,' the hurry of mankind out of this brief world into the unchangeable and endless next,- - I have heard him, with deep feeling, repeat Andrew Marvel's strong lines :-

' But at my back I always hear

Time's wingèd chariots hurrying near ;

And yonder all before me lie

Deserts of vast eternity.'

His living so much on books, and his strong personal attachment to men, as distinct from his adhesion to their principles and views, made him, as it were, live and commune with the dead-made him intimate, 
not merely with their thoughts, and the public events of their lives, but with themselves-Augustine, Milton, Luther, Melanchthon, George Herbert, Baxter, Howe, Owen, Leighton, Barrow, Bunyan, Philip and Matthew Henry, Doddridge, Defoe, Marvel, Locke, Berkeley, Halliburton, Cowper, Gray, Johnson, Gibbon, and David Hume, ${ }^{1}$ Jortin, Boston, Bengel, Neander, etc., not to speak of the apostles, and above all, his chief friend the author of the Epistle to the Romans, whom he looked on as the greatest of men,-with all these he had personal relations as men, he cordialized with them. He had thought much more about themwould have had more to say to them had they met, than about or to any but a very few living men. ${ }^{2} \mathrm{He}$

${ }^{1}$ David Hume's Treatise on Human Nature he knew thoroughly, and read it carefully during his last illness. He used to say it not only was a miracle of intellectual and literary power for a man of twenty-eight, but contained the essence of all that was best on the philosophy of mind ; 'It's all there, if you will think it out.'

2 This tendency was curiously seen in his love of portraits, especially of men whose works he had and liked. He often put portraits into his books, and he seemed to enjoy this way of realizing their authors; and in exhibitions of pictures he was more taken up with what is usually and justly the most tiresome department, the portraits, than with all else. He was not learned in engravings, and made no attempt at collecting them, so that the following list of portraits in his rooms shows his liking for the men much more than for the art which delineated them. Of course they by no means include all his friends, ancient and modern, but they all were his friends :-

Robert Hall-Dr. Carey-Melanchthon-Calvin-Pollok- 


\section{Letter to Fohn Cairns, D.D.}

delighted to possess books which any of them might have held in their hands, on which they had written their names. He had a number of these, some very curious; among others, that wild soldier, man of fashion and wit among the reformers, Ulric von Hütten's autograph on Erasmus' beautiful folio Greek Testament, and John Howe's (spelt How) on the first edition of Milton's Speech on Unlicensed Printing. ${ }^{1}$ He began collecting books when he was twelve, and he was collecting up to his last hours. He cared least for merely fine books, though he enjoyed, no one more so, fine type, good binding, and all the niceties of the book-fancier. What he liked were such books as were directly useful in his work, and such as he liked to live in the midst of ; such, also,

Erasmus (very like 'Uncle Ebenezer')-John Knox-Dr. Waugh-John Milton (three, all framed)-Dr. Dick-Dr. Hall -Luther (two) -Dr. Heugh-Dr. Mitchell-Dr. Balmer-Dr. Henderson-Dr. Wardlaw-Shakspere (a small oil painting which he had since ever I remember)-Dugald Stewart-Dr. Innes-Dr. Smith, Biggar-the two Erskines and Mr. FisherDr. John Taylor of Toronto-Dr. Chalmers-Mr. William Ellis, Rev. James Elles-J. B. Patterson-Vinet-Archibald I' 'Lean-Dr. John Erskine-Tholuck-John Pym-Gesenius - Professor Finlayson-Richard Baxter-Dr. Lawson-Dr. Peddie (two, and a copy of Joseph's noble bust) ; and they were thus all about him for no other reason than that he liked to look at and think of them through their countenances.

${ }^{1}$ In a copy of Baxter's Life and Times, which he picked up at Maurice Ogle's shop in Glasgow, which had belonged to Anna, Countess of Argyll, besides her autograph, there is a most affecting and interesting note in that venerable lady's handwrit- 
as illustrated any great philosophical, historical, or ecclesiastical epoch. His collection of Greek Testaments was, considering his means, of great extent and value, and he had a quite singular series of books, pamphlets, and documents, referring not merely to his own body-the Secession, with all its subdivisions and reunions-but to Nonconformity and Dissent everywhere, and, indeed, to human liberty, civil and religious, in every form,--for this, after the great truths, duties, and expectations of his faith, was the one master passion of his life-liberty in its greatest sense, the largest extent of individual and public spontaneity consistent with virtue and safety. $\mathrm{He}$ was in this as intense, persistent in his devotion,

ing. It occurs on the page where Baxter brings a charge of want of veracity against her eldest and name-daughter who was perverted to Popery. They are in a hand tremulous with age and feeling:- " I can say wt truth I neuer in all my lyff did hear hirly, and what she said, if it was not trew, it was by others sugested to hir, as $\mathrm{y}^{\mathrm{t}}$ she wold embak on Wedensday. She belived she wold, bot thy took hir, alles! from me who never did sie her mor. The minester of Cuper, Mr. John Magill, did sie hir at Paris in the convent. Said she was a knowing and vertuous person, and hed retined the living principels of our relidgon, which made him say it was good to grund young persons weel in ther relidgion, as she was one it appired weel grunded."

The following is Lord Lindsay's letter, on seeing this remarkable marginal note :-

\section{Edinburgh, Douglas' Hotel, 26 th December 1856 .}

MY DEAR SIR, - I owe you my sincerest thanks for your 
as Sydney, Locke, or old Hollis. For instance, his admiration of Lord Macaulay as a writer and a man of letters, an orator and a statesman, great as it was, was as nothing to his gratitude to him for having placed permanently on record, beyond all risk of obscuration or doubt, the doctrine of 1688 - the right and power of the English people to be their own lawgivers, and to appoint their own magistrates, of whom the sovereign is the chief.

His conviction of the sole right of God to be Lord of the conscience, and his sense of his own absolute religious independence of every one but his Maker, were the two elements in building up his beliefs on all church matters; they were twin beliefs. Hence the simplicity and thoroughness of his principles.

kindness in favouring me with a sight of the volume of Baxter's Life, which formerly belonged to my ancestrix, Anna, Countess of Argyll. The MS. note inserted by her in it respecting her daughter is extremely interesting. I had always been under the impression that the daughter had died very shortly after her removal to France, but the contrary appears from Lady Argyll's memorandum. That memorandum throws also a pleasing light on the later life of Lady Anna, and forcibly illustrates the undying love and tenderness of the aged mother, who must have been very old when she penned it, the book having been printed as late as 1696 .

I am extremely obliged to you for communicating to me this new and very interesting information.-Believe me, my dear Sir, your much obliged and faithful servant,

LINDSAY.

John Brown, Esq, M.D. 
Sitting in the centre, he commanded the circumference. But I am straying out of my parish into yours. I only add to what you have said, that the longer he lived, the more did he insist upon it being not less true and not less important, that the Church must not intermeddle with the State, than that the State must not intermeddle with the Church. He used to say, 'Go down into the world, with all its complications and confusions, with this double-edged weapon, and you can cut all the composite knots of Church and State.' The element of God and of eternity predominates in the religious more than in the civil affairs of men, and thus far transcends them; but the principle of mutual independence is equally applicable to each. All that statesmen, as such, have to do with religion, is to be themselves under its power; all that Christians, as such, have to do with the State, is to be good citizens.

The fourth epoch of his personal life I would date from his second marriage. As I said before, no man was ever happier in his wives. They had much alike in nature,--only one could see the Divine wisdom of his first wife being his first, and his second his second; each did best in her own place and time. His marriage with Miss Crum was a source of great happiness and good not only to himself, but to us his first children. She had been intimately known to us for many years, and was endeared to us long before 


\section{Letter to Fohn Cairns, D.D.}

we saw her, by her having been, as a child and girl, a great favourite of our own mother. The families of my grandfather Nimmo, and of the Crums, Ewings, and Maclaes, were very intimate. I have heard my father tell, that being out at Thornliebank with my mother, he asked her to take a walk with him to the Rouken, a romantic waterfall and glen up the burn. My mother thought they might take 'Miss Margaret' with them, and so save appearances, and with Miss Crum, then a child of ten, holding my father's hand, away the three went!

So you may see that no one could be nearer to being our mother; and she was curiously ingenious, and completely successful in gaining our affection and regard. I have, as a boy, a peculiarly pleasant remembrance of her, having been at Thornliebank when about fourteen, and getting that impression of her gentle, kind, wise, calm, and happy natureher entire loveableness-which it was our privilege to see ministering so much to my father's comfort. That fortnight in 1824 or 1825 is still to me like the memory of some happy dream; the old library, the big chair in which I huddled myself up for hours with the New Arabian Nights, and all the oldfashioned and unforgotten books I found there, the ample old garden, the wonders of machinery and skill going on in 'the works,' the large waterwheel going its stately rounds in the midst of its 
own darkness, the petrifactions I excavated in the bed of the burn, ammonites, etc., and brought home to my museum (!) ; the hospitable lady of the house, my hereditary friend, dignified, anxious and kind; and above all, her only daughter who made me a sort of pet, and was always contriving some unexpected pleasure,-all this feels to me even now like something out of a book.

My father's union with Miss Crum was not only one of the best blessings of his life,-it made him more of a blessing to others, than it is likely he would otherwise have been. Byi her cheerful, gracious ways, her love for society as distinguished from company, her gift of making every one happy and at ease when with her, and her tender compassion for all suffering, she in a measure won my father from himself and his books, to his own great good, and to the delight and benefit of us all. It was like sunshine and a glad sound in the house. She succeeded in what is called 'drawing out' the inveterate solitary. Moreover, she encouraged and enabled him to give up a moiety of his ministerial labours, and thus to devote himself to the great work of his later years, the preparing for and giving to the press the results of his life's study of God's Word. We owe entirely to her that immense armamentarium libertatis, the third edition of his treatise on Civil Obedience. 


\section{Letter to Fohn Cairns, D.D.}

One other source of great happiness to my father by this marriage was the intercourse he had with the family at Thornliebank, deepened and endeared as this was by her unexpected and irreparable loss. But on this I must not enlarge, nor on that death itself, the last thing in the world he ever fearedleaving him once more, after a brief happiness, and when he had still more reason to hope that he would have 'grown old with her, leaning on her faithful bosom.' The urn was again empty-and the only word was vale! he was once more viduus, bereft.

' God gives us love; something to love - He lends us ; but, when love is grown To ripeness, that on which it throve

Falls off, and love is left alone. This is the curse of time.'-

But still

' 'Tis better to have loved and lost, Than never to have loved at all.'

It was no easy matter to get him from home and away from his books. But once off, he always enjoyed himself,-especially in his visits to Thornliebank, Busby, Crofthead, Biggar, and Melrose. He was very fond of preaching on these occasions, and his services were always peculiarly impressive. He spoke more slowly and with less vehemence than in his own pulpit, and, as I often told him, with all the 
more effect. When driving about Biggar, or in the neighbourhood of Langrig, he was full of the past, showing how keenly, with all his outward reserve, he had observed and felt. He had a quite peculiar interest in his three flocks, keeping his eye on all their members, through long years of absence.

His love for his people and for his 'body' was a special love; and his knowledge of the Secession, through all its many divisions and unions,- - his knowledge, not only of its public history, with its immense controversial and occasional literature, but of the lives and peculiarities of its ministers, - was of the most minute and curious kind. He loved all mankind, and specially such as were of 'the household of faith ;' and he longed for the time when, as there was one Shepherd, there would be but one sheepfold; but he gloried in being not only a Seceder, but a Burgher; and he often said, that take them all in all, he knew no body of professing Christians in any country or in any time, worthier of all honour than that which was founded by the Four Brethren, not only as God-fearing, God-serving men, but as members of civil society; men who on every occasion were found on the side of liberty and order, truth and justice. He used to say he believed there was hardly a Tory in the Synod, and that no one but He whose service is perfect freedom, knew the public good done, and the public evil averted, by the lives 


\section{Letter to Fohn Cairns, D.D.}

and the principles, and when need was, by the votes of such men, all of whom were in the working-classes, or in the lower half of the middle. The great Whig leaders knew this, and could always depend on the Seceders.

There is no worthy portrait of my father in his prime. I believe no man was ever more victimized in the way of being asked to 'sit;' indeed, it was probably from so many of them being of this kind, that the opportunity of securing a really good one was lost. The best-the one portrait of his habitual expression-is Mr. Harvey's, done for Mr. Crum of Busby: it was taken when he was failing, but it is an excellent likeness as well as a noble picture; such a picture as one would buy without knowing anything of the subject. So true it is, that imaginative painters, men gifted and accustomed to render their own ideal conceptions in form and colour, grasp and impress on their canvas the features of real men more to the quick, more faithfully as to the central qualities of the man, then professed portrait painters.

Steell's bust is beautiful, but it is wanting in expression. Slater's, though rude, is better. Angus Fletcher's has much of his air, but is too much like a Grecian god. There is a miniature by Mrs. Robertson of London, belonging to my sister, Mrs. Young, which I always liked, though more like a gay, brilliant French Abbé, than the Seceder minister of Rose 
Street, as he then was. It gives, however, more of his exquisite brightness and spirit, the dancing light in his dark eyes, and his smile, when pleased and desiring to please, than any other. I have a drawing by Mr. Harvey, done from my father for his picture of the Minister's Visit, which I value very much, as giving the force and depth, the momentum, so to speak, of his serious look. He is sitting in a cottar's house, reading the Bible to an old bed-ridden woman, the farm servants gathered round to get his word.

Mungo Burton painted a good portrait which my brother William has; from his being drawn in a black neckcloth, and standing, he looks as he sometimes did, more like a member of Parliament than a clergyman. The print from this is good and very scarce. Of Photographs, I like D. O. Hill's best, in which he is represented as shaking hands with the (invisible) Free Church-it is full of his earnest, cordial power; that by Tunny, from which the beautiful engraving by Lumb Stocks in this Memoir was taken, is very like what he was about a year and a half before his death. All the other portraits, as far as I can remember, are worthless and worse, missing entirely the true expression. He was very difficult to take, partly because he was so full of what may be called spiritual beauty, evanescent, ever changing, and requiring the highest kind of genius to fix it ; and partly from his own fault, for he thought it was necessary to 


\section{Letter to Fohn Cairns, D.D.}

be lively, or rather to try to be so to his volunteering artist, and the consequence was, his giving them, as his habitual expression, one which was rare, and in this particular case more made than born.

The time when I would have liked his look to have been perpetuated, was that of all others the least likely, or indeed possible;-it was, when after administering the Sacrament to his people, and having solemnized every one, and been himself profoundly moved by that Divine, everlasting memorial, he left the elders' seat and returned to the pulpit, and after giving out the psalm, sat down wearied and satisfied, filled with devout gratitude to his Master-his face pale, and his dark eyes looking out upon us all, his whole countenance radiant and subdued. Any likeness of him in this state, more like that of the protomartyr, when his face was as that of an angel, than anything I ever beheld, would have made one feel what it is so impossible otherwise to convey,-the mingled sweetness, dignity, and beauty of his face. When it was winter, and the church darkening, and the lights at the pulpit were lighted so as to fall upon his face and throw the rest of the vast assemblage into deeper shadow, the effect of his countenance was something never to forget.

He was more a man of power than of genius in the ordinary sense. His imagination was not a primary power; it was not originative, though in a quite un- 
common degree receptive, having the capacity of realizing the imaginations of others, and through them bodying forth the unseen. When exalted and urged by the understanding, and heated by the affections, it burst out with great force, but always as servant, not master. But if he had no one faculty that might be, to use the loose words of common speech, original, he was so as a whole,- - such a man as stood alone. No one ever mistook his look, or would, had they been blind, have mistaken his voice or words, for those of any one else, or any one else's for his.

His mental characteristics, if I may venture on such ground, were clearness and vigour, intensity, fervour, ${ }^{1}$ concentration, penetration, and perseverance, - more of depth than width. ${ }^{2}$ The moral

1 This earnestness of nature pervaded all his exercises. A man of great capacity and culture, with a head like Benjamin Franklin's, an avowed unbeliever in Christianity, came every Sunday afternoon, for many years, to hear him. I remember his look well, as if interested, but not impressed. He was often asked by his friends why he went when he didn't believe one word of what he heard. 'Neither I do, but I like to hear and to see a man earnest once a week, about anything.' It is related of David Hume, that having heard my great-grandfather preach, he said, 'That's the man for me, he means what he says ; he speaks as if Jesus Christ was at his elbow.'

2 The following note from the pen to which we owe 'St. Paul's Thorn in the Flesh' is admirable, both for its reference to my father, and its own beauty and truth.

'One instance of his imperfect discernment of associations of thought that were not of a purely logical character was afforded, 


\section{Letter to Fohn Cairns, D.D.}

conditions under which he lived were the love, the pursuit, and the practice of truth in everything; strength and depth, rather than external warmth of affection; fidelity to principles and to friends. $\mathrm{He}$ used often to speak of the moral obligation laid upon every man to think truly, as well as to speak and act truly, and said that much intellectual demoralization and ruin resulted from neglecting this. $\mathrm{He}$ was absolutely tolerant of all difference of opinion, so that it was sincere; and this was all the more remarkable from his being the opposite of an indifferentist, being very strong in his own convictions, holding them keenly, even passionately, while, from the structure of his mind, he was somehow deficient in comprehending, much less of sympathizing with the opinions of men who greatly differed from him.

we used to think, by the decided and almost contemptuous manner in which he always rejected the theory of what is called the double interpretation of prophecy. This, of course, is not the place to discuss whether he was absolutely right or wrong in his opinion. The subject, however, is one of somewhat curious interest, and it has also a strictly literary as well as a theological aspect, and what we have to say about it shall relate exclusively to the former. When Dr. Brown then said, as he was accustomed in his strong way to do, that "if prophecy was capable of two senses, it was impossible it could have any sense at all," it is plain, we think, that he forgot the specific character of prophetic literature, viz., its being in the highest degree poetic. Now every one knows that poetry of a very elevated cast almost invariably possesses great breadth, variety, we may say multiplicity of meaning. Its very excellence consists in its being capable of two, three, or many meanings and applications. Take, 
This made his homage to entire freedom of thought all the more genuine and rare. In the region of theological thought he was scientific, systematic, and authoritative, rather than philosophical and speculative. He held so strongly that the Christian religion was mainly a religion of facts, that he perhaps allowed too little to its also being a philosophy that was ready to meet, out of its own essence and its ever unfolding powers, any new form of unbelief, disbelief, or misbelief, and must front itself to them as they moved up.

With devotional feeling - with everything that showed reverence and godly fear-he cordialized for example, these familiar lines in the "Midsummer Night's Dream :"-

\footnotetext{
"Ah me! for aught that ever I could read,

Could ever hear by tale or history,

The course of true love never did run smooth :

But either it was different in blood,

Or else misgraffed in respect of years,

Or else it stood upon the choice of friends ;

Or if there were a sympathy in choice,

War, death, or sickness did lay siege to it,

Making it momentary as a sound,

Swift as a shadow, short as any dream,

Brief as the lightning in the collied night,

That in a spleen unfolds both heaven and earth,

And ere a man hath power to say 'Behold!'

The jaws of darkness do devour it up;

So quick bright things come to confusion."
}

We remember once quoting these lines to a lady, and being rather taken aback by her remark, "They are very beautiful, but I don't think they are true." We really had forgot for the moment the straightforward, matter-of-fact sense of which they are capable, and were not adverting to the possibility of their being 


\section{Letter to Fohn Caims, D.D.}

wherever and in whomsoever it was found,-Pagan or Christian, Romanist or Protestant, bond or free ; and while he disliked, and had indeed a positive antipathy to intellectual mysticism, he had a great knowledge of and relish for such writers as Dr. Henry More, Culverwel, Scougall, Madame Guyon, whom (besides their other qualities) I may perhaps be allowed to call affectionate mystics, and for such poets as Herbert and Vaughan, whose poetry was pious, and their piety poetic. As I have said, he was perhaps too impatient of all obscure thinking, from not considering that on certain subjects, necessarily in their substance, and on the skirts of all subjects,

understood to mean that-nothing but love-crosses are going, and that no tolerable amount of comfort or happiness is to be found in the life matrimonial, or in any of the approaches towards it. Every intelligent student of Shakspere, however, will at once feel that the poet's mind speedily passes away from the idea with which he starts, and becomes merged in a far wider theme, viz., in the disenchantment to which all lofty imaginations are liable, the disappointment to which all extravagant earthly hopes and wishes are doomed. This, in fact, is distinctly expressed in the last line, and in this sense alone can the words be regarded as at all touching or impressive. Sudden expansions and transitions of thought, then, are nothing more than what is common to all poetry; and when we find the Hebrew bards, in their prophetic songs, mingling in the closest conjunction the anticipations of the glories of Solomon's reign, or the happy prospects of a return from Babylon, with the higher glory and happiness of Messiah's advent, such transitions of thought are in perfect accordance with the ordinary laws of poetry, and ought not to perplex even the most unimaginative student of the Bible.' 
obscurity and vagueness, difficulty and uncertainty, are inherent, and must therefore appear in their treatment. Men who rejoiced in making clear things obscure, and plain things the reverse, he could not abide, and spoke with some contempt of those who were original merely from their standing on their heads, and tall from walking upon stilts. As you have truly said, his character mellowed and toned down in his later years, without in any way losing its own individuality, and its clear, vigorous, unflinching perception of and addiction to principles.

His affectionate ways with his students were often very curious : he contrived to get at their hearts, and find out all their family and local specialities, in a sort of short-hand way, and he never forgot them in after life ; and watching him with them at tea, speaking his mind freely and often jocularly upon all sorts of subjects, one got a glimpse of that union of opposites which made him so much what he washe gave out far more liberally to them the riches of his learning and the deep thoughts of his heart, than he ever did among his full-grown brethren. It was like the flush of an Arctic summer, blossoming all over, out of and into the stillness, the loneliness, and the chill rigour of winter. Though authoritative in his class without any effort, he was indulgent to everything but conceit, slovenliness of mind and body, irreverence, and above all handling the Word 


\section{Letter to Fohn Cairns, D.D.}

of God deceitfully. On one occasion a student having delivered in the Hall a discourse tinged with Arminianism, he said, "That may be the gospel according to Dr. Macknight, or the gospel according to Dr. Taylor of Norwich, but it is not the gospel according to the Apostle Paul; and if I thought the sentiments expressed were his own, if I had not thought he has taken his thoughts from commentators without carefully considering them, I would think it my duty to him and to the church to make him no longer a student of divinity here.' He was often unconsciously severe, from his saying exactly what he felt. On a student's ending his discourse, his only criticism was, 'the strongest characteristic of this discourse is weakness,' and feeling that this was really all he had to say, he ended. A young gentleman on very good terms with himself, stood up to pray with his hands in his pockets, and among other things he put up a petition that he might 'be delivered from the fear of man, which bringeth a snare ;' my father's only remark was, that there was part of his prayer which seemed to be granted before it was asked. But he was always unwilling to criticise prayer, feeling it to be too sacred, and as it were beyond his province, except to deliver the true principles of all prayer, which he used to say were admirably given in the Shorter Catechism'Prayer is an offering up of the desires of the heart 
to God, for things agreeable to his will, in the name of Christ ; with confession of our sins, and thankful acknowledgment of his mercies.'

For the 'heroic' old man of Haddington my father had a peculiar reverence, as indeed we all have - as well we may. He was our king, the founder of our dynasty; we dated from him, and he was 'hedged' accordingly by a certain sacredness or 'divinity.' I well remember with what surprise and pride I found myself asked by a blacksmith's wife in a remote hamlet among the hop gardens of Kent, if I was 'the son of the Self-interpreting Bible.' I possess, as an heirloom, the New Testament which my father fondly regarded as the one his grandfather, when a herd-laddie, got from the Professor who heard him ask for it, and promised him it if he could read a verse; and he has in his beautiful small hand written in it what follows :' He (John Brown of Haddington) had now acquired so much of Greek as encouraged him to hope that he might at length be prepared to reap the richest of all rewards which classical learning could confer on him, the capacity of reading in the original tongue the blessed New Testament of our Lord and Saviour. Full of this hope, he became anxious to possess a copy of the invaluable volume. One night, having committed the charge of his sheep to a companion, he set out on a midnight journey to St. Andrews, a 


\section{Letter to Fohn Cairns, D.D.}

distance of twenty-four miles. He reached his destination in the morning, and went to the bookseller's shop, asking for a copy of the Greek New Testament. The master of the shop, surprised at such a request from a shepherd boy, was disposed to make game of him. Some of the professors coming into the shop, questioned the lad about his employment and studies. After hearing his tale, one of them desired the bookseller to bring the volume. He did so, and drawing it down, said, "Boy, read this, and you shall have it for nothing." The boy did so, acquitted himself to the admiration of his judges, and carried off his Testament, and when the evening arrived, was studying it in the midst of his flock on the braes of Abernethy.'-Memoir of Rev. John Brown of Haddington, by Rev. J. B. Patterson.

'There is reason to believe this is the New Testament referred to. The name on the opposite page was written on the fly-leaf. It is obviously the writing of a boy, and bears a resemblance to Mr. Brown's handwriting in mature life. It is imperfect, wanting a great part of the Gospel of Matthew. The autograph at the end is that of his son, Thomas, when a youth at college, afterwards Rev. Dr. Thomas Brown of Dalkeith.-J. B.'

I doubt not my father regarded this little worn old book, the sword of the Spirit which his ancestor so nobly won, and wore, and warred with, with not less 
honest veneration and pride than does his dear friend James Douglas of Cavers the Percy pennon borne away at Otterbourne. When I read, in Uncle William's admirable Life of his father, his own simple story of his early life-his loss of father and mother before he was eleven, his discovering (as true a discovery as Dr. Young's of the characters of the Rosetta stone, or Rawlinson's of the cuneiform letters) the Greek characters, his defence of himself against the astonishing and base charge of getting his learning from the devil (that shrewd personage would not have employed him on the Greek Testament), his eager, indomitable study, his running miles to and back again to hear a sermon after folding his sheep at noon, his keeping his family creditably on never more than $£_{5}$ o, and for long on $£_{4}$ o a year, giving largely in charity, and never wanting, as he said, 'lying money' - when I think of all this, I feel what a strong, independent, manly nature he must have had. We all know his saintly character, his devotion to learning, and to the work of preaching and teaching; but he seems to have been, like most complete men, full of humour and keen wit. Some of his snell sayings are still remembered. A lad of an excitable temperament waited on him, and informed him he wished to be a preacher of the gospel. My greatgrandfather, finding him as weak in intellect as he was strong in conceit, advised him to continue in his 


\section{Letter to Fohn Cairns, D.D.}

present vocation. The young man said, 'But I wish to preach and glorify God.' ' My young friend, a man may glorify God making broom besoms; stick to your trade, and glorify God by your walk and conversation.'

The late Dr. Husband of Dunfermline called on him when he was preparing to set out for Gifford, and was beginning to ask him some questions as to the place grace held in the Divine economy. 'Come away wi' me, and I'll expound that; but when I'm speaking, look you after my feet.' They got upon a rough bit of common, and the eager and full-minded old man was in the midst of his unfolding the Divine scheme, and his student was drinking in his words, and forgetting his part of the bargain. His master stumbled and fell, and getting up, somewhat sharply said, 'James, the grace o' God can do much, but it canna gi'e a man common sense;' which is as good theology as sense.

A scoffing blacksmith seeing him jogging up to a house near the smithy on his pony, which was halting, said to him, 'Mr. Brown, ye're in the Scripture line the day - " the legs o' the lame are not equal."' 'So is a parable in the mouth of a fool.'

On his coming to Haddington, there was one man who held out against his ' call.' Mr. Brown meeting him when they could not avoid each other, the noncontent said, 'Ye see, sir, I canna say what I dinna think, and I think ye're ower young and inexperienced 
for this charge.' 'So I think too, David, but it would never do for you and me to gang in the face o' the hale congregation!'

The following is a singular illustration of the prevailing dark and severe tone of the religious teaching of that time, and also of its strength :-A poor old woman, of great worth and excellent understanding, in whose conversation Mr. Brown took much pleasure, was on her death-bed. Wishing to try her faith, he said to her, 'Janet, what would you say if, after all He has done for you, God should let you drop into hell ?' 'E'en's (even as) he likes; if he does, $\mathrm{He}^{\prime} l l$ lose mair than I'll do.' There is something not less than sublime in this reply.

Than my grandfather and ' Uncle Ebenezer,' no two brothers could be more different in nature or more united in affection. My grandfather was a man of great natural good sense, well read and well knowledged, easy but not indolent, never overflowing but never empty, homely but dignified, and fuller of love to all sentient creatures than any other human being I ever knew. I had, when a boy of ten, two rabbits, Oscar and Livia: why so named is a secret I have lost; perhaps it was an Ossianic union of the Roman with the Gael. Oscar was a broad-nosed, manly, rather brusque husband, who used to snort when angry, and bite too; Livia was a thin-faced, meek, and, I fear, deceitfullish wife, who could smile, and 


\section{Letter to Fohn Cairns, D.D.}

then bite. One evening I had lifted both these worthies, by the ears of course, and was taking them from their clover to their beds, when my grandfather, who had been walking out in the cool of the evening, met me. I had just kissed the two creatures, out of mingled love to them, and pleasure at having caught them without much trouble. He took me by the chin, and kissed me, and then Oscar and Livia! Wonderful man, I thought, and still think! doubtless he had seen me in my private fondness, and wished to please me.

He was for ever doing good in his quiet yet earnest way. Not only on Sunday when he preached solid gospel sermons, full of quaint and familiar expressions, such as I fear few of my readers could take up, full of solemn, affectionate appeals, full of his own simplicity and love, the Monday also found him ready with his everyday gospel. If he met a drover from Lochaber who had crossed the Campsie Hills, and was making across Carnwath Moor to the Calstane Slap, and thence into England by the drove-road, he accosted him with a friendly smile,-gave him a reasonable tract, and dropped into him some words of Divine truth. He was thus continually doing good. Go where he might, he had his message to every one; to a servant lass, to a poor wanderer on the bleak streets, to gentle and simple-he flowed for ever pleno rivo. 
Uncle Ebenezer, on the other hand, flowed per saltum; he was always good and saintly, but he was great once a week; six days he brooded over his message, was silent, withdrawn, self-involved; on the Sabbath, that downcast, almost timid man, who shunned men, the instant he was in the pulpit, stood up a son of thunder. Such a voice! such a piercing eye ! such an inevitable forefinger, held out trembling with the terrors of the Lord; such a power of asking questions and letting them fall deep into the hearts of his hearers, and then answering them himself, with an 'ah, sirs !' that thrilled and quivered from him to them.

I remember his astonishing us all with a sudden burst. It was a sermon upon the apparent plus of evil in this world, and he had driven himself and us all to despair-so much sin, so much misery-when, taking advantage of the chapter he had read, the account of the uproar at Ephesus in the Theatre, he said, "Ah, sirs! what if some of the men who, for "about the space of two hours," cried out, "Great is Diana of the Ephesians," have for the space of eighteen hundred years and more been crying day and night, "Great and marvellous are thy works, Lord God Almighty; just and true are all thy ways, thou King of saints ; who shall not fear thee, O Lord, and glorify thy name? for thou only art holy."'

You have doubtless heard of the story of Lord 


\section{Letter to Fohn Cairns, D.D.}

Brougham going to hear him. It is very characteristic, and as I had it from Mrs. Cuninghame, who was present, I may be allowed to tell it. Brougham and Denman were on a visit to James Stuart of Dunearn, about the time of the Queen's trial. They had asked Stuart where they should go to church; he said he would take them to a Seceder minister at Inverkeithing. They went, and as Mr. Stuart had described the saintly old man, Brougham said he would like to be introduced to him, and arriving before service time, Mr. Stuart called, and left a message that some gentlemen wished to see him. The answer was that 'Maister' Brown saw nobody before divine worship. He then sent in Brougham and Denman's names. 'Mr. Brown's compliments to Mr. Stuart, and he sees nobody before sermon,' and in a few minutes out came the stooping shy old man, and passed them, unconscious of their presence. They sat in the front gallery, and he preached a faithful sermon, full of fire and of native force. They came away greatly moved, and each wrote to Lord Jeffrey to lose not a week in coming to hear the greatest natural orator they had ever heard. Jeffrey came next Sunday, and often after declared he never heard such words, such a sacred, untaught gift of speech. Nothing was more beautiful than my father's admiration and emotion when listening to his uncle's rapt passages, or than his childlike faith in my father's exegetical prowess. 
He used to have a list of difficult passages ready for 'my. nephew,' and the moment the oracle gave a decision, the old man asked him to repeat it, and then took a permanent note of it, and would assuredly preach it some day with his own proper unction and power. One story of him I must give; my father, who heard it not long before his own death, was delighted with it, and for some days repeated it to every one. Uncle Ebenezer, with all his mildness and general complaisance, was, like most of the Browns, tenax propositi, firm to obstinacy. He had established a week-day sermon at the North Ferry, about two miles from his own town, Inverkeithing. It was, I think, on the Tuesdays. It was winter, and a wild, drifting, and dangerous day; his daughters-his wife was dead-besought him not to go; he smiled vaguely, but continued getting into his big-coat. Nothing would stay him, and away he and the pony stumbled through the dumb and blinding snow. $\mathrm{He}$ was half-way on his journey, and had got into the sermon he was going to preach, and was utterly insensible to the outward storm : his pony getting its feet balled, staggered about, and at last upset his master and himself into the ditch at the roadside. The feeble, heedless, rapt old man might have perished there, had not some carters, bringing up whisky casks from the Ferry, seen the catastrophe, and rushed up, raising him, and dichtin' him, with much commisera- 


\section{Letter to Fohn Cairns, D.D.}

tion and blunt speech-'Puir auld man, what brocht ye here in sic a day?' There they were, a rough crew, surrounding the saintly man, some putting on his hat, sorting and cheering him, and others knocking the balls off the pony's feet, and stuffing them with grease. He was most polite and grateful, and one of these cordial ruffians having pierced a cask, brought him a horn of whisky, and said, 'Tak that, it'll hearten ye.' He took the horn, and bowing to them, said, 'Sirs, let us give thanks !' and there, by the road-side, in the drift and storm, with these wild fellows, he asked a blessing on it, and for his kind deliverers, and took a tasting of the horn. The men cried like children. They lifted him on his pony, one going with him, and when the rest arrived in Inverkeithing, they repeated the story to everybody, and broke down in tears whenever they came to the blessing. 'And to think o' askin' a blessin' on a tass o' whisky!' Next Presbytery day, after the ordinary business was over, he rose up-he seldom spoke -and said, 'Moderator, I have something personal to myself to say. I have often said, that real kindness belongs only to true Christians, but'-and then he told the story of these men; 'but more true kindness I never experienced than from these lads. They may have had the grace of God, I don't know ; but I never mean again to be so positive in speaking of this matter.' 
When he was on a missionary tour in the north, he one morning met a band of Highland shearers on their way to the harvest; he asked them to stop and hear the word of God. They said they could not, as they had their wages to work for. He offered them what they said they would lose; to this they agreed, and he paid them, and closing his eyes engaged in prayer; when he had ended, he looked up, and his congregation had vanished! His shrewd brother Thomas, to whom he complained of this faithlessness, said, 'Eben, the next time ye pay folk to hear you preach, keep your eyes open, and pay them when you are done.' I remember on another occasion, in Bristo Church, with an immense audience, he had been going over the Scripture accounts of great sinners repenting and turning to God: repeating their names, from Manasseh onwards. $\mathrm{He}$ seemed to have closed the record, when, fixing his eyes on the end of the central passage, he called out abruptly, 'I see a man!' Every one looked to that point-' I see a man of Tarsus; and he says, Make mention of me !' It must not be supposed that the discourses of 'Uncle Ebenezer,' with these abrupt appeals and sudden starts, were unwritten or extempore ; they were carefully composed and written out, - only these flashes of thought and passion came on him suddenly when writing, and were therefore quite natural when delivered-they came on him again. 


\section{Letter to Fohn Cairns, D.D.}

The Rev. John Belfrage, M.D., had more power over my father's actions and his relations to the world, than any other of his friends: over his thoughts and convictions proper, not much - few living men had, and even among the mighty dead, he called no man master. He used to say that the three master intellects devoted to the study of divine truth since the apostles, were Augustine, Calvin, and Jonathan Edwards; but that even they were only primi inter pares,- - this by the bye.

On all that concerned his outward life as a public teacher, as a father, and as a member of society, he consulted Dr. Belfrage, and was swayed greatly by his judgment, as, for instance, the choice of a profession for myself, his second marriage, etc. He knew him to be his true friend, and not only wise and honest, but pre-eminently a man of affairs, capax rerum. Dr. Belfrage was a great man in posse, if ever I saw one, - 'a village Hampden.' Greatness was of his essence; nothing paltry, nothing secondary, nothing untrue. Large in body, large and handsome in face, lofty in manner to his equals or superiors, ${ }^{1}$ homely, familiar, cordial, with the young and the poor, - I never met with a more

${ }^{1}$ On one occasion, Mr. Hall of Kelso, an excellent but very odd man, in whom the ego was very strong, and who, if he had been a Spaniard, would, to adopt Coleridge's story, have taken off or touched his hat whenever he spoke of himself, met Dr. Belfrage in the lobby of the Synod, and drawing himself up as 
truly royal nature-more native and endued to rule, guide, and benefit mankind. $\mathrm{He}$ was for ever scheming for the good of others, and chiefly in the way of helping them to help themselves. From a curious want of ambition - his desire for advancement was for that of his friends, not for his own, and here he was ambitious and zealous enough,from non-concentration of his faculties in early life, and from an affection of the heart which ultimately killed him-it was too big for his body, and; under the relentless hydrostatic law, at last shattered the tabernacle it moved, like a steam-engine too powerful for the vessel it finds itself in,--his mental heart also was too big for his happiness, - from these causes, along with a love for gardening, which was a passion, and an inherited competency, which took away what John Hunter calls 'the stimulus of necessity,' you may understand how this remarkable man, instead of being a Prime Minister, a Lord Chancellor, or a Dr. Gregory, a George Stephenson, or likeliest of all, a John Howard, without some of his weaknesses, lived and died minister of the small congregation of Slateford, near Edinburgh. It is also true that he was a physician, and an energetic and successful one, and got rid of some of his love of doing good to and managing human beings in this way; he

he passed, he muttered, 'high and michty!' 'There's a pair of us, Mr. Hall.' 


\section{Letter to Fohn Cairns, D.D.}

was also an oracle in his district, to whom many had the wisdom to go to take as well as ask advice, and who was never weary of entering into the most minute details, and taking endless pains, being like Dr. Chalmers a strong believer in 'the power of littles.' It would be out of place, though it would be not uninteresting, to tell how this great resident power-this strong will and authority, this capacious, clear, and beneficent intellect-dwelt in its petty sphere, like an oak in a flower-pot; but I cannot help recalling that signal act of friendship and of power in the matter of my father's translation from Rose Street to Broughton Place, to which you have referred.

It was one of the turning-points of my father's history. Dr. Belfrage, though seldom a speaker in the public courts of his Church, was always watchful of the interests of the people and of his friends. On the Rose Street question he had from the beginning formed a strong opinion. My father had made his statement, indicating his leaning, but leaving himself absolutely in the hands of the Synod. There was some speaking, all on one side, and for a time the Synod seemed to incline to be absolute, and refuse the call of Broughton Place. The house was everywhere crowded, and breathless with interest, my father sitting motionless, anxious, and pale, prepared to submit without a word, but retaining his own 
mind; everything looked like a unanimous decision for Rose Street, when Dr. Belfrage rose up and came forward into the 'passage,' and with his first sentence and look, took possession of the house. He stated, with clear and simple argument, the truth and reason of the case; and then having fixed himself there, he took up the personal interests and feelings of his friend, and putting before them what they were about to do in sending back my father, closed with a burst of indignant appeal-' I ask you now, not as Christians, I ask you as gentlemen, are you prepared to do this?' Every one felt it was settled, and so it was. My father never forgot this great act of his friend.

This remarkable man, inferior to my father in learning, in intensity, in compactness and in power of -so to speak-focussing himself,-admiring his keen eloquence, his devotedness to his sacred art, rejoicing in his fame, jealous of his honour-was, by reason of his own massive understanding, his warm and great heart, and his instinctive knowledge of men, my father's most valued friend, for he knew best and most of what my father knew least; and on his death, my father said he felt himself thus far unprotected and unsafe. He died at Rothesay of hypertrophy of the heart. I had the sad privilege of being with him to the last; and any nobler spectacle of tender, generous affection, high courage, child-like submission to the Supreme Will, and of magnanimity in its 
true sense, I do not again expect to see. On the morning of his death he said to me, 'John, come and tell me honestly how this is to end; tell me the last symptoms in their sequence.' I knew the man, and was honest, and told him all I knew. 'Is there any chance of stupor or delirium?' 'I think not. Death (to take Bichat's division) will begin at the heart itself, and you will die conscious.' 'I am glad of that. It was Samuel Johnson, wasn't it, who wished not to die unconscious, that he might enter the eternal world with his mind unclouded; but you know, John, that was physiological nonsense. We leave the brain, and all this ruined body, behind; but I would like to be in my senses when I take my last look of this wonderful world,' looking across the still sea towards the Argyleshire hills, lying in the light of sunrise, 'and of my friends - of you,' fixing his eyes on a faithful friend and myself. And it was so; in less than an hour he was dead, sitting erect in his chair-his disease had for weeks prevented him from lying down,-all the dignity, simplicity, and benignity of its master resting upon, and, as it were, supporting that 'ruin,' which he had left.

I cannot end this tribute to my father's friend and mine, and my own dear and earliest friend's father, without recording one of the most extraordinary instances of the power of will, under the pressure of affection, I ever witnessed or heard of. Dr. Belfrage 
was twice married. His second wife was a woman of great sweetness and delicacy, not only of mind, but, to his sorrow, of constitution. She died, after less than a year of singular and unbroken happiness. There was no portrait of her. He resolved there should be one; and though utterly ignorant of drawing, he determined to do it himself. No one else could have such a perfect image of her in his mind, and he resolved to realize this image. He got the materials for miniature painting, and, I think, eight prepared ivory plates. He then shut himself up from every one, and from everything, for fourteen days, and came out of his room, wasted and feeble, with one of the plates (the others he had used and burnt), on which was a portrait, full of subtle likeness, and drawn and coloured in a way no one could have dreamt of, having had such an artist. I have seen it; and though I never saw the original, I felt that it must be like, as indeed every one who knew her said it was. I do not, as I said before, know anything more remarkable in the history of human sorrow and resolve.

I remember well that Dr. Belfrage was the first man I ever heard speak of Free-trade in religion and in education. It was during the first election after the Reform Bill, when Sir John Dalrymple, afterwards Lord Stair, was canvassing the county of MidLothian. They were walking in the doctor's garden, 
Sir John anxious and gracious. Dr. Belfrage, like, I believe, every other minister in his body, was a thoroughgoing Liberal, what was then called a Whig; but partly from his natural sense of humour and relish of power, and partly, I believe, for my benefit, he was putting the Baronet through his facings with some strictness, opening upon him startling views, and ending by asking him, 'Are you, Sir John, for free-trade in corn, free-tràde in education, free-trade in religion? I am.' Sir John said, 'Well, doctor, I have heard of free-trade in corn, but never in the other two.' 'You'll hear of them before ten years are gone, Sir John, or I'm mistaken.'

I have said thus much of this to me memorable man, not only because he was my father's closest and most powerful personal friend, but because by his word he probably changed the whole future course of his life. Devotion to his friends was one of the chief ends of his life, not caring much for, and having in the affection of his heart a warning against the perils and excitement of distinction and energetic public work, he set himself far more strenuously than for any selfish object, to promote the triumphs of those whom his acquired instinct-for he knew a man as a shepherd knows a sheep, or ' Caveat Emptor' a horse-picked out as deserving them. He rests in Colinton churchyard,

'Where all that mighty heart is lying still,'- 
his only child William Henry buried beside him. I the more readily pay this tribute to Dr. Belfrage, that I owe to him the best blessing of my professional and one of the best of my personal life-the being apprenticed to Mr. Syme. This was his doing. With that sense of the capacities and capabilities of other men, which was one of his gifts, he predicted the career of this remarkable man. He used to say, 'Give him life, let him live, and I know what and where he will be thirty years hence;' and this long before our greatest clinical teacher and wisest surgeon, had made the public and the profession feel and acknowledge the full weight of his worth.

Another life-long and ever-strengthening friendship was that with James Henderson, D.D., Galashiels, who survived my father only a few days. This remarkable man, and exquisite preacher, whose intellect and worth had for nearly fifty years glowed with a pure, steady, and ever-growing warmth and lustre in his own region, died during the night, and probably asleep, when, like Moses, no one but his Maker was with him. He had for years laboured under that form of disease of the heart called angina pectoris (Dr. Arnold's disease), and for more than twenty years lived as it were on the edge of instant death ; but during his later years his health had improved, though he had always to 'walk softly,' like one whose next step might be into eternity. This bodily 
sense of peril gave to his noble and leonine face a look of suffering and of seriousness, and of what, in his case, we may truly call godly fear, which all must remember. He used to say he carried his grave beside him. He came in to my father's funeral, and took part in the services. He was much affected, and we fear the long walk through the city to the burial-place was too much for him ; he returned home, preached a sermon on his old and dear friend's death of surpassing beauty. The text was, 'For me to live is Christ, and to die is gain.' It was, as it were, his own funeral sermon too, and there was, besides its fervour, depth, and heavenly-mindedness, a something in it that made his old hearers afraid - as if it were to be the last crush of the grapes. In a letter to me soon after the funeral, he said :- ' His removal is another memento to me that my own course is drawing near to its end. Nearly all of my contemporaries and of the friends of my youth are now gone before me. Well! I may say, in the words of your friend Vaughan-

"They are all gone to that world of light,

And I alone sit lingering here ;

Their very memory's calm and bright, And my sad thoughts doth cheer.",

The evening before his death he was slightly unwell, and next morning, not coming down as usual, was called, but did not answer; and on going in, was found in the posture of sleep, quite dead: at some 
unknown hour of the night abiit ad plures-he had gone over to the majority, and joined the famous nations of the dead. Tu vero felix non vite tantum claritate, sed etiam opportunitate mortis! dying with his lamp burning, his passport made out for his journey; death an instant act, not a prolonged process of months, as with his friend.

I have called Dr. Henderson a remarkable man, and an exquisite preacher; he was both, in the strict senses of the words. He had the largest brain I ever saw or measured. His hat had to be made for him ; and his head was great in the nobler regions; the anterior and upper were full, indeed immense. If the base of his brain and his physical organization, especially his circulating system, had been in proportion, he would have been a man of formidable power, but his defective throb of the heart, and a certain lentitude of temperament, made this impossible; and his enormous organ of thought and feeling, being thus shut from the outlet of active energy, became intensely meditative, more this than even reflective. The consequence was, in all his thoughts an exquisiteness and finish, a crystalline lustre, purity, and concentration; but it was the exquisiteness of a great nature. If the first edge was fine, it was the sharp end of a wedge, the broad end of which you never reached, but might infer. This gave momentum to everything he said. He was in the true sense what 


\section{Letter to Fohn Caims, D.D.}

Chalmers used to call 'a man of wecht.' His mind acted by its sheer absolute power; it seldom made an effort; it was the hydraulic pressure, harmless, manageable, but irresistible; not the perilous compression of steam. Therefore it was that he was untroubled and calm, though rich; clear, though deep; though gentle, never dull; 'strong without rage, without o'erflowing full.' Indeed this element of water furnishes the best figure of his mind and its expression. His language was like the stream of his own Tweed; it was a translucent medium, only it brightened everything seen through it, as wetting a pebble brings out its lines and colour. That lovely, and by him much-loved river, was curiously like him, or he like it, gentle, great, strong, with a prevailing mild seriousness all along its course, but clear and quiet; sometimes, as at old Melrose, turning upon itself, reflecting, losing itself in beauty, and careless to go, deep and inscrutable, but stealing away cheerily down to Lessudden, all the clearer of its rest; and then again at the Trows, showing unmistakably its power in removing obstructions and taking its own way, and chafing nobly with the rocks, sometimes, too, like him, its silver stream rising into sudden flood, and rolling irresistibly on its way. ${ }^{1}$

1 Such an occasional paroxysm of eloquence is thus described by Dr. Cairns:- 'At certain irregular intervals, when the loftier themes of the gospel ministry were to be handled, his manner underwent a transformation which was startling, and 
We question if as many carefully thought and worded, and rapidly and by no means laboriously written sermons, were composed anywhere else in Britain during his fifty years-every Sunday two new ones; the composition faultless - such as Cicero or Addison would have made them, had they been U.P. ministers; only there was always in them more soul than body, more of the spirit than of the letter. What a contrast to the much turbid, hot, hasty, perilous stuff of our day and preachers! The original power and size of Dr. Henderson's mind, his roominess for all thoughts, and his still reserve, his lentitude, made, as we have said, his expressions clear and quiet, to a degree that a coarse and careless man, spoiled by the violence and noise of other pulpit men, might think insipid. But let him go over the words slowly, and he would not say this again; and let him see and feel the solemnizing, commanding power of that large, square, leonine countenance, even electrical. He became rapt and excited as with new inspiration; his utterance grew thick and rapid ; his voice trembled and faltered with emotion; his eye gleamed with a wild unearthly lustre, in which his countenance shared; and his whole frame heaved to and fro, as if each glowing thought and vivid figure that followed in quick succession were only a fragment of some greater revelation which he panted to overtake. The writer of this notice has witnessed nothing similar in any preacher, and numbers the effects of a passage which he once heard upon the scenes and exercises of the heavenly world among his most thrilling recollections of sacred oratory.'-Memoir prefixed to posthumous volume of Discourses. 
the broad massive frame, as of a compressed Hercules, and the living, pure, melodious voice, powerful, but not by reason of loudness, dropping out from his compressed lips the words of truth, and he would not say this again. His voice had a singular pathos in it; and those who remember his often-called-for sermon on the 'Bright and the Morning Star,' can reproduce in their mind its tores and refrain. The thoughts of such men-so rare, so apt to be unvisited and unvalued - often bring into my mind a spring of pure water I once saw near the top of Cairngorm; always the same, cool in summer, keeping its few plants alive and happy with its warm breath in winter, floods and droughts never making its pulse change; and all this because it came from the interior heights, and was distilled by nature's own cunning, and had taken its time-was indeed a well of living water. And with Dr. Henderson this of the mountain holds curiously; he was retired, but not concealed; and he was of the primary formation, he had no organic remains of other men in him; he liked and fed on all manner of literature; knew poetry well; but it was all outside of him; his thoughts were essentially his own.

He was peculiarly a preacher for preachers, as Spenser is a poet for poets. They felt he was a master. He published, after the entreaties of years, a volume of sermons which has long been out of 
print, and which he would never prepare for a second edition; he had much too little of the love of fame, and though not destitute of self-reliance and selfvalue, and resolved and unchangeable to obstinacy, he was not in the least degree vain.

But you will think I am writing more about my father's friends and myself than about him. In a certain sense we may know a man by his friends; a man chooses his friends from harmony, not from sameness, just as we would rather sing in parts than all sing the air. One man fits into the mind of another not by meeting his points, but by dovetailing; each finds in the other what he in a double sense wants. This was true of my father's friends. Dr. Balmer was like him in much more than perhaps any, -in love of books and lonely study, in his general views of divine truth, and in their metaphysical and literary likings, but they differed deeply. Dr. Balmer was serene and just rather than subtle and profound; his was the still, translucent stream,-my father's the rapid, and it might be deep; on the one you could safely sail, the other hurried you on, and yet never were two men, during a long life of intimate intercourse, more cordial.

I must close the list; one only and the best- the most endeared of them all-Dr. Heugh. He was, in mental constitution and temper, perhaps more unlike my father than any of the others I have mentioned. 


\section{Letter to Fohn Cairns, D.D.}

His was essentially a practical understanding; he was a man of action, a man for men more than for man, the curious reverse in this of my father. He delighted in public life, had a native turn for affairs, for all that society needs and demands,-clear-headed, ready, intrepid, adroit; with a fine temper, but keen and honest, with an argument and a question and a joke for every one; not disputatious, but delighting in a brisk argument, fonder of wrestling than of fencing, but ready for action; not much of a long shot, always keeping his eye on the immediate, the possible, the attainable, but in all this guided by genuine principle, and the finest honour and exactest truth. He excelled in the conduct of public business, saw his way clear, made other men see theirs, was for ever getting the Synod out of difficulties and confusions, by some clear, tidy, conclusive 'motion ;' and then his speaking, so easy and bright and pithy, manly and gentlemanly, grave when it should be, never when it should not-mobile, fearless, rapid, brilliant as Saladin-his silent, pensive, impassioned and emphatic friend was more like the lion-hearted Richard, with his heavy mace; he might miss, but let him hit, and there needed no repetition. Each admired the other; indeed Dr. Heugh's love of my father was quite romantic; and though they were opposed on several great public questions, such as the Apocrypha controversy, the Atonement question 
at its commencement; and though they were both of them too keen and too honest to mince matters or be mealy-mouthed, they never misunderstood each other, never had a shadow of estrangement, so that our Paul and Barnabas, though their contentions were sometimes sharp enough, never 'departed asunder;' indeed they loved each other the longer the more.

Take him all in all, as a friend, as a gentleman, as a Christian, as a citizen, I never knew a man so thoroughly delightful as Dr. Heugh. Others had more of this or more of that, but there was a symmetry, a compactness, a sweetness, a true delightfulness about him I can remember in no one else. No man with so much temptation to be heady and highminded, sarcastic, and managing, from his overflowing wit and talent, was ever more natural, more honest, or more considerate, indeed tender-hearted. He was full of animal spirits and of fun, and one of the best wits and jokers I ever knew; and such an asker of questions, of posers! We children had a pleasing dread of that nimble, sharp, exact man, who made us explain and name everything. Of Scotch stories he had as many original ones as would make a second volume for Dean Ramsay. How well I remember the very corner of the room in Biggar manse, forty years ago, when from him I got the first shock and relish of humour; became conscious of mental tickling; of a word being made to carry 


\section{Letter to Fohn Cairns, D.D.}

double and being all the lighter of it. It is an old story now, but it was new then: a big, perspiring countryman rushed into the Black Bull coach-office, and holding the door, shouted, 'Are yir insides a' oot?' This was my first tasting of the flavour of a joke.

Had Dr. Heugh, instead of being the admirable clergyman he was, devoted himself to public civil life, and gone into Parliament, he would have taken a high place as a debater, a practical statesman and patriot. He had many of the best qualities of Canning, and our own Premier, with purer and higher qualities than either. There is no one our church should be more proud of than of this beloved and excellent man, the holiness and humility, the jealous, godly fear in whose nature was not known fully even to his friends, till he was gone, when his private daily self-searchings and prostrations before his Master and Judge were for the first time made known. There are few characters, both sides of which are so unsullied, so pure, and without reproach.

I am back at Biggar at the old sacramental times; I see and hear my grandfather, or Mr. Horne of Braehead, Mr. Leckie of Peebles, Mr. Harper of Lanark, as inveterate in argument as he was warm in heart, Mr. Comrie of Penicuik, with his keen, Voltaire-like face, and much of that unhappy and unique man's wit, and sense, and perfection of expression, without his darker and baser qualities. I 
can hear their hearty talk, can see thein coming and going between the meeting-house and the Tent on the side of the burn, and then the Monday dinner, and the cheerful talk, and the many clerical stories and pleasantries, and their going home on their hardy little horses, Mr. Comrie leaving his curl-papers till the next solemnity, and leaving also some joke of his own, clear and compact as a diamond, and as cutting.

I am in Rose Street on the monthly lecture, the church crammed, passages and pulpit stairs. Exact to a minute, James Chalmers--the old soldier and beadle, slim, meek, but incorruptible by proffered half-crowns from ladies who thus tried to get in before the doors opened-appears, and all the people in that long pew rise up, and he, followed by his minister, erect and engrossed, walks in along the seat, and they struggle up to the pulpit. We all know what he is to speak of; he looks troubled even to distress; - it is the matter of Uriah the Hittite. He gives out the opening verses of the 5 Ist Psalm, and offering up a short and abrupt prayer, which every one takes to himself, announces his miserable and dreadful subject, fencing it, as it were, in a low, penetrating voice, daring any one of us to think an evil thought; there was little need at that time of the warning, - he infused his own intense, pure spirit, into us all. 


\section{Letter to Fohn Cairns, D.D.}

He then told the story without note or comment, only personating each actor in the tragedy with extraordinary effect, above all, the manly, loyal, simplehearted soldier. I can recall the shudder of that multitude as of one man when he read, 'And it came to pass in the morning, that David wrote a letter to Joab, and sent it by the hand of Uriah. And he wrote in the letter, saying, Set ye Uriah in the forefront of the hottest battle, and retire ye from him, that he may be smitten and die.' And then, after a long and utter silence, his exclaiming, 'Is this the man according to God's own heart? Yes, it is ; we must believe that both are true.' Then came Nathan. 'There were two men in one city; the one rich, and the other poor. The rich man had exceeding many flocks and herds; but the poor man had nothing, save one little ewe lamb'-and all that exquisite, that divine fable-ending, like a thunderclap, with, 'Thou art the man!' Then came the retribution, so awfully exact and thorough, - the misery of the child's death; that brief tragedy of the brother and sister, more terrible than anything in Aschylus, in Dante, or in Ford; then the rebellion of Absalom, with its hideous dishonour, and his death, and the king covering his face, and crying in a loud voice, 'O my son Absalom! O Absalom ! my son! my son!'-and David's psalm, 'Have mercy upon me, O God, according to thy loving-kindness; 
according unto the multitude of thy tender mercies blot out my transgressions,'- - then closing with, 'Yes ; "when lust hath conceived, it bringeth forth sin: and $\sin$, when it is finished, bringeth forth death. Do not err," do not stray, do not transgress ( $\mu$ ì $\pi \lambda \alpha \nu \hat{\sigma} \sigma \theta \epsilon), 1$ " my beloved brethren," it is first "earthly, then sensual, then devilish ;" 'he shut the book, and sent us all away terrified, shaken, and humbled, like himself.

I would fain say a few words on my father's last illness, or rather on what led to it, and I wish you and others in the ministry would take to heart, as matter of immediate religious duty, much of what I am going to say. My father was a seven months' child, and lay, I believe, for a fortnight in black wool, undressed, doing little but breathe and sleep, not capable of being fed. He continued all his life slight in make, and not robust in health, though lively, and capable of great single efforts. His attendance upon his mother must have saddened his body as well as his mind, and made him willing and able to endure, in spite of his keen and ardent spirit, the sedentary life he in the main led. He was always a very small eater, and nice in his tastes, easily put off from his food by any notion. He therefore started on the full work of life with a finer

${ }^{1}$ James i. 15, I6. It is plain that 'do not err' should have been in verse 15 th. 


\section{Letter to Fohn Cairns, D.D.}

and more delicate mechanism than a man's ought to be, indeed, in these respects he was much liker a woman; and being very soon 'placed,' he had little travelling, and little of that tossing about the world, which, in the transition from youth to manhood, hardens the frame as well as supples it. Though delicate, he was almost never ill. I do not remember, till near the close of his life, his ever being in bed a day.

From his nervous system, and his brain predominating steadily over the rest of his body, he was habitually excessive in his professional work. As to quantity, as to quality, as to manner and expression, he flung away his life without stint every Sabbathday, his sermons being laboriously prepared, loudly mandated, and at great expense of body and mind, and then delivered with the utmost vehemence and rapidity. He was quite unconscious of the state he worked himself into, and of the loud piercing voice in which he often spoke. This I frequently warned him about, as being, I knew, injurious to himself, and often painful to his hearers, and his answer always was, that he was utterly unaware of it; and thus it continued to the close, and very sad it was to me who knew the peril, and saw the coming end, to listen to his noble, rich, persuasive, imperative appeals, and to know that the surplus of power, if retained, would, by God's blessing, retain him, while 
the effect on his people would, I am sure, not have lost, but in some respects have gained, for much of the discourse which was shouted and sometimes screamed at the full pitch of his keen voice, was of a kind to be better rendered in his deep, quiet, settled tones. This, and the great length of his public services, I knew he himself felt, when too late, had injured him, and many a smile he had at my proposal to have a secret sub-congregational string from him to me in the back seat, to be authoritatively twitched when I knew he had done enough; but this string was never pulled, even in his mind.

He went on in his expensive life, sleeping very little, and always lightly, eating little, never walking except of necessity ; little in company, when he would have eaten more, and been, by the power of social relish, made likelier to get the full good out of his food; never diverting his mind by any change but that of one book or subject for another; and every time that any strong affliction came on him, as when made twice a widower, or at his daughter's death, or from such an outrage upon his entire nature and feelings as the Libel, then his delicate machinery was shaken and damaged, not merely by the first shock, but even more by that unrelenting self-command by which he terrified his body into instant submission. Thus it was, and thus it ever must be, if the laws of our bodily constitution, laid down by Him who 
knows our frame, and from whom our substance is not hid, are set at nought, knowingly or not-if knowingly, the act is so much the more spiritually bad-but if not, it is still punished with the same unerring nicety, the same commensurate meting out of the penalty, and paying 'in full tale,' as makes the sun to know his time, and splits an erring planet into fragments, driving it into space 'with hideous ruin and combustion.' It is a pitiful and a sad thing to say, but if my father had not been a prodigal in a true but very different meaning, if he had not spent his substance, the portion of goods that fell to him, the capital of life given him by God, in what we must believe to have been needless and therefore preventable excess of effort, we might have had him still with us, shining more and more, and he and they who were with him would have been spared those two years of the valley of the shadow, with its sharp and steady pain, its fallings away of life, its longing for the grave, its sleepless nights and days of weariness and languor, the full expression of which you will find nowhere but in the Psalms and in Job.

I have said that though delicate he was never ill : this was all the worse for him, for, odd as it may seem, many a man's life is lengthened by a sharp illness ; and this in several ways. In the first place, he is laid up, out of the reach of all external mischief and exertion, he is like a ship put in dock for repairs ; 
time is gained. A brisk fever clarifies the entire man, if it is beaten and does not beat; it is like cleaning a chimney by setting it on fire; it is perilous but thorough. Then the effort to throw off the disease often quickens and purifies and corroborates the central powers of life; the flame burns more clearly; there is a cleanness, so to speak, about all the wheels of life. Moreover, it is a warning, and makes a man meditate on his bed, and resolve to pull up; and it warns his friends, and likewise, if he is a clergyman, his people, who if their minister is always with them, never once think he can be ever anything but as able as he is.

Such a pause, such a breathing-time my father never got during that part of his life and labours when it would have availed most, and he was an old man in years, before he was a regular patient of any doctor. He was during life subject to sudden headaches, affecting his memory and eyesight, and even his speech; these attacks were, according to the thoughtless phrase of the day, called bilious; that is, he was sick, and was relieved by a blue pill and smart medicine. Their true seat was in the brain; the liver suffered because the brain was ill, and sent no nervous energy to it, or poisoned what it did send. The sharp racking pain in the forehead was the cry of suffering from the anterior lobes, driven by their master to distraction, and turning on him wild with 


\section{Letter to Fohn Cairns, D.D. $\quad$ I $\mathrm{I}$}

weakness and fear and anger. It was well they did cry out; in some brains (large ones) they would have gone on dumb to sudden and utter ruin, as in apoplexy or palsy; but he did not know, and no one told him their true meaning, and he set about seeking for the outward cause in some article of food, in some recent and quite inadequate cause.

He used, with a sort of odd shame and distress, to ask me why it was that he was subjected to so much suffering from what he called the lower and ignoble regions of his body; and I used to explain to him that he had made them suffer by long years of neglect, and that they were now having their revenge, and in their own way. I have often found, that the more the nervous centres are employed in those offices of thought and feeling the most removed from material objects, - the more the nervous energy of the entire nature is concentrated, engrossed, and used up in such offices, - so much the more, and therefore, are those organs of the body which preside over that organic life, common to ourselves and the lowest worm, defrauded of their necessary nervous food,- - and being in the organic and not in the animal department, and having no voice to tell their wants or wrongs, till they wake up and annoy their neighbours who have a voice, that is, who are sensitive to pain, they may have been long ill before they come into the sphere of 
consciousness. This is the true reason-along with want of purity and change of air, want of exercise, ${ }^{1}$ want of shifting the work of the body-why clergymen, men of letters, and all men of intense mental application, are so liable to be affected with indigestion, constipation, lumbago, and lowness of spirits, melancholia - black bile. The brain may not give way for long, because for a time the law of exercise strengthens it ; it is fed high, gets the best of everything, of blood and nervous pabulum, and then men have a joy in the victorious work of their brain, and it has a joy of its owr, too, which deludes and misleads.

All this happened to my father. He had no formal disease when he died - no structural change; his sleep and his digestion would have been quite sufficient for life even up to the last; the mechanism was entire, but the motive power was gone-it was expended. The silver cord was not so much loosed as relaxed. The golden bowl, the pitcher at the fountain, the wheel at the cistern, were not so much broken as emptied and stayed. The clock had run down before its time, and there was no one but $\mathrm{He}$

1 'The youth Story was in all respects healthy, and even robust; he died of overwork, or rather, as I understand, of a two years' almost total want of exercise, which it was impossible to induce him to take.'-Amold's Report to the Committee of Consucil on Education, I860. 


\section{Letter to Fohn Cairns, D.D.}

who first wound it up and set it who could wind it up again; and this $\mathrm{He}$ does not do, because it is His law - an express injunction from Him - that, having measured out to His creatures each his measure of life, and left him to the freedom of his own will and the regulation of his reason, $\mathrm{He}$ also leaves him to reap as he sows.

Thus it was that my father's illness was not so much a disease as a long death; life ebbing away, consciousness left entire, the certain issue never out of sight. This, to a man of my father's organization - with a keen relish for life, and its highest pleasures and energies, sensitive to impatience, and then over sensitive of his own impatience; cut to the heart with the long watching and suffering of those he loved, who, after all, could do so little for him; with a nervous system easily sunk, and by its strong play upon his mind darkening and saddening his most central beliefs, shaking his most solid principles, tearing and terrifying his tenderest affections ; his mind free and clear, ready for action if it had the power, eager to be in its place in the work of the world and of its Master, to have to spend two long years in this ever-descending road-here was a combination of positive and negative suffering not to be thought of even now, when it is all sunk under that 'far more exceeding and eternal weight of glory.' 
He often spoke to me freely about his health, went into it with the fearlessness, exactness, and persistency of his nature; and I never witnessed, or hope to witness, anything more affecting than when, after it had been dawning upon him, he apprehended the true secret of his death. He was deeply humbled, felt that he had done wrong to himself, to his people, to us all, to his faithful and long-suffering Master; and he often said, with a dying energy lighting up his eye, and nerving his voice and gesture, that if it pleased God to let him again speak in his old place, he would not only proclaim again, and, he hoped, more simply and more fully, the everlasting gospel to lost man, but proclaim also the gospel of God to the body, the religious and Christian duty and - privilege of living in obedience to the divine laws of health. He was delighted when I read to him, and turned to this purpose that wonderful passage of St. Paul - 'For the body is not one member, but many. If the whole body were an eye, where were the hearing? if the whole were hearing, where were the smelling? But now hath God set the members every one of them in the body, as it hath pleased him. And the eye cannot say unto the hand, I have no need of thee; nor again the head to the feet, I have no need of you. Nay, much more those members of the body which seem to be more feeble, are necessary ;' summing it all up in words with life and 


\section{Letter to Fohn Cairns, D.D. $\quad 105$}

death in them - 'That there should be no schism in the body; but that the members should have the same care one for another. And whether one member suffer, all the members suffer with it; or one member be honoured, all the members rejoice with it.'

The lesson from all this is, Attend to your bodies, study their structure, functions, and laws. This does not at all mean that you need be an anatomist, or go deep into physiology, or the doctrines of prevention and cure. Not only has each organism a resident doctor, placed there by Him who can thus heal all our diseases ; but this doctor, if watched and waited on, informs any man or woman of ordinary sense what things to do, and what things not to do. And I would have you, who, I fear, not unfrequently sin in the same way, and all our ardent, self-sacrificing young ministers, to reflect whether, after destroying themselves and dying young, they have lost or gained. It is said that God raises up others in our place. God gives you no title to say this. Men-such men as I have in my mind-are valuable to God in proportion to the time they are here. They are the older, the better, the riper and richer, and more enriching. Nothing will make up for this absolute loss of life. For there is something which every man who is a good workman is gaining every year just because he is older, and this nothing can replace. Let a man remain 
on his ground, say a country parish, during half a century or more - let him be every year getting fuller and sweeter in the knowledge of God and man, in utterance and in power-can the power of that man for good over all his time, and especially towards its close, be equalled by that of three or four young, and, it may be admirable men, who have been succeeding each other's untimely death, during the same space of time? It is against all spiritual, as well as all simple arithmetic, to say so.

You have spoken of my father's prayers. They were of two kinds : the one, formal, careful, systematic, and almost stereotyped, remarkable for fulness and compression of thought: sometimes too manifestly the result of study, and sometimes not purely prayer, but more of the nature of a devotional and even argumentative address; the other, as in the family, short, simple, and varied. He used to tell of his master, Dr. Lawson, reproving him, in his honest but fatherly way, as they were walking home from the Hall. My father had in his prayer the words, 'that through death he might destroy him that had the power of death, that is, the devil.' The old man, leaning on his favourite pupil, said, 'John, my man, you need not have said "that is, the devil;" you might have been sure that $H e$ knew whom you meant.' My father, in theory, held that a mixture of formal, fixed prayer, in fact, a liturgy, along with extempore prayer, was the right 


\section{Letter to Fohn Cairns, D.D.}

thing. As you observe, many of his passages in prayer, all who were in the habit of hearing him could anticipate, such as 'the enlightening, enlivening, sanctifying, and comforting influences of the good Spirit,' and many others. One in especial you must remember; it was only used on very solemn occasions, and curiously unfolds his mental peculiarities; it closed his prayer-'And now, unto Thee, O Father, Son, and Holy Ghost, the one Jehovah and our God, we would - as is most meet-with the church on earth and the church in heaven, ascribe all honour and glory, dominion and majesty, as it was in the beginning, is now, and ever shall be, world without end. Amen.' Nothing could be liker him than the interjection, 'as is most meet.' Sometimes his abrupt, short statements in the Synod were very striking. On one occasion, Mr. James Morison, having stated his views as to prayer very strongly, denying that a sinner can pray, my father, turning to the moderator, said- 'Sir, let a man feel himself to be a sinner, and, for anything the universe of creatures can do for him, hopelessly lost,let him feel this, sir, and let him get a glimpse of the Saviour, and all the eloquence and argument of Mr. Morison will not keep that man from crying out, "God be merciful to me a sinner." That, sir, is prayerthat is acceptable prayer.'

There must be, I fear, now and then an apparent 
discrepancy between you and me, especially as to the degree of mental depression which at times overshadowed my father's nature. You will understand this, and I hope our readers will make allowance for it. Some of it is owing to my constitutional tendency to overstate, and much of it to my having had perhaps more frequent, and even more private, insights into this part of his life. But such inconsistency as that I speak of--the co-existence of a clear, firm faith, a habitual sense of God and of his infinite mercy, the living a life of faith, as if it was in his organic and inner life, more than in his sensational and outward -is quite compatible with that tendency to distrust himself, that bodily darkness and mournfulness, which at times came over him. Any one who knows 'what a piece of work is man ;' how composite, how varying, how inconsistent human nature is, that each of us is

'Some twenty several men, all in an hour,'

-will not need to be told to expect, or how to harmonize, these differences of mood. You see this in that wonderful man, the apostle Paul, the true typical fulness, the humanness, so to speak, of whose nature comes out in such expressions of opposites as these - By honour and dishonour, by evil report and good report : as deceivers and yet true; as unknown, and yet well known; as dying, and behold we live; as 


\section{Letter to Fohn Cairns, D.D.}

chastened, and not killed; as sorrowful, yet alway rejoicing; as poor, yet making many rich ; as having nothing, and yet possessing all things.'

I cannot, and after your impressive and exact his. tory of his last days, I need not say anything of the close of those long years of suffering, active and passive, and that slow ebbing of life ; the body, without help or hope, feeling its doom steadily though slowly drawing on; the mind mourning for its suffering friend, companion, and servant, mourning also, sometimes, that it must be 'unclothed,' and take its flight all alone into the infinite unknown; dying daily, not in the heat of fever, or in the insensibility or lethargy of paralytic disease, but having the mind calm and clear, and the body conscious of its own decay,dying, as it were, in cold blood. One thing I must add. That morning when you were obliged to leave, and when 'cold obstruction's apathy' had already begun its reign-when he knew us, and that was all, and when he followed us with his dying and loving eyes, but could not speak - the end came ; and then, as through life, his will asserted itself supreme in death. With that love of order and decency which was a law of his life, he deliberately composed himself, placing his body at rest, as if setting his house in order before leaving it, and then closed his eyes and mouth, so that his last look-the look his body 
carried to the grave and faced dissolution in--was that of sweet, dignified self-possession.

I have made this letter much too long, and have said many things in it I never intended saying, and omitted much I had hoped to be able to say. But I must end.

Yours ever affectionately,

J. BROWN. 


\section{DR. CHALMERS.}

'Fervet immensusque ruit.'-HoR.

'His memory long wili live alone

In all our hearts, as mournful light

That broods above the fallen sun,

And dwells in heaven half the night.'

Tennyson.

'He avas not one man, he wias a thousand men.'-SyDney SMITH. 



\section{DR. CHALMERS.}

$W^{\text {HEN, towards the close of some long summer }}$ day, we come suddenly, and, as we think, before his time, upon the broad sun, 'sinking down in his tranquillity' into the unclouded west ; we cannot keep our eyes from the great spectacle;--and when he is gone, the shadow of him haunts our sight with the spectre of his brightness, which is dark when our eyes are open; luminous when they are shut: we see everywhere,-upon the spotless heaven, upon the distant mountains, upon the fields, and upon the road at our feet, - that dim, strange, changeful image; and if our eyes shut, to recover themselves, we still find in them, like a dying flame, or like a gleam in a dark place, the unmistakable phantom of the mighty orb that has set,- and were we to sit down, as we have often done, and try to record by pencil or by pen, our impression of that supreme hour, still would IT be there. We must have patience with our eye, it will not let the im- 
pression go,- - that spot on which the radiant disc was impressed, is insensible to all other outward things, for a time: its best relief is, to let the eye wander vaguely over earth and sky, and repose itself on the mild shadowy distance.

So it is when a great and good and beloved man departs, sats-it may be suddenly-and to us who know not the times and the seasons, too soon. We gaze eagerly at his last hours, and when he is gone, never to rise again on our sight, we see his image wherever we go, and in whatsoever we are engaged, and if we try to record by words our wonder, our sorrow, and our affection, we cannot see to do it, for the 'idea of his life' is for ever coming into our 'study of imagination'-into all our thoughts, and we can do little else than let our mind, in a wise passiveness, hush itself to rest.

The sun returns - he knows his rising-

'To-morrow he repairs his drooping head, And tricks his beams, and with new spangled ore Flames in the forehead of the morning sky ;'

but man lieth down, and riseth not again till the heavens are no more. Never again will he whose 'Meditations' are now before us, lift up the light of his countenance upon us.

We need not say we look upon him as a great man, as a good man, as a beloved man-quis desiderio sit pudor tam cari capitis? We cannot now go very 
curiously to work, to scrutinize the composition of his character, - we cannot take that large, free, genial nature to pieces, and weigh this and measure that, and sum up and pronounce; we are too near as yet to him, and to his loss, he is too dear to us to be so handled. 'His death,' to use the pathetic words of Hartley Coleridge, 'is a recent sorrow; his image still lives in eyes that weep for him.' The prevailing feeling is,-He is gone-' abiit ad plures-he has gone over to the majority, he has joined the famous nations of the dead.'

It is no small loss to the world, when one of its master spirits-one of its great lights-a king among the nations-leaves it. A sun is extinguished; a great attractive, regulating power is withdrawn. For though it be a common, it is also a natural thought, to compare a great man to the sun; it is in many respects significant. Like the sun, he rules his day, and he is 'for a sign and for seasons, and for days and for years ;' he enlightens, quickens, attracts, and leads after him his host-his generation.

To pursue our image. When the sun sets to us, he rises elsewhere-he goes on rejoicing, like a strong man, running his race. So does a great man : when he leaves us and our concerns-he rises elsewhere; and we may reasonably suppose that one who has in this world played a great part in its greatest histories -who has through a long life been pre-eminent for 
promoting the good of men and the glory of Godwill be looked upon with keen interest, when he joins the company of the immortals. They must have heard of his fame; they may in their ways have seen and helped him already.

Every one must have trembled when reading that passage in Isaiah, in which Hell is described as moved to meet Lucifer at his coming : there is not in human language anything more sublime of conception, more exquisite in expression; it has on it the light of the terrible crystal. But may we not reverse the scene? May we not imagine, when a great and good man-a son of the morning-enters on his rest, that Heaven would move itself to meet him at his coming? that it would stir up its dead, even all the chief ones of the earth, and that the kings of the nations would arise each one from his throne to welcome their brother? that those who saw him would 'narrowly consider him,' and say, 'Is this he who moved nations, enlightened and bettered his fellows, and whom the great Taskmaster welcomes with "Well done!",

We cannot help following him, whose loss we now mourn, into that region, and figuring to ourselves his great, childlike spirit, when that unspeakable scene bursts upon his view, when, as by some inward, instant sense, he is conscious of God-of the immediate presence of the All-seeing Unseen; when he beholds 
'His honourable, true, and only Son,' face to face, enshrined in that 'glorious form, that light unsufferable, and that far-beaming blaze of Majesty,' that brightness of His glory, that express image of His person; when he is admitted into the goodly followship of the apostles - the glorious company of the prophets - the noble army of martyrs - the general assembly of just men-and beholds with his loving eyes the myriads of ' little ones,' outnumbering their elders as the dust of the stars with which the galaxy is filled exceeds in multitude the hosts of heaven.

What a change! death the gate of life-a second birth, in the twinkling of an eye : this moment, weak, fearful, in the amazement of death; the next, strong, joyful, - at rest, -all things new ! To adopt his own words : all his life, up to the last, ' knocking at a door not yet opened, with an earnest, indefinite longing, his very soul breaking for the longing,-drinking of water and thirsting again '-and then-suddenly and at once-a door opened into heaven, and the Master heard saying, 'Come in, and come up hither!' drinking of the river of life, clear as crystal, of which if a man drink he will never thirst,--being filled with all the fulness of God !

Dr. Chalmers was a ruler among men : this we know historically; this every man who came within his range felt at once. He was like Agamemnon, a native $\alpha^{\prime} \nu \alpha_{\xi} \xi$ 
$\dot{a} \nu \delta \rho \hat{\omega} \nu$, and with all his homeliness of feature and deportment, and his perfect simplicity of expression, there was about him 'that divinity that doth hedge a king.' You felt a power, in him, and going from him, drawing you to him in spite of yourself. He was in this respect a solar man, he drew after him his own firmament of planets. They, like all free agents, had their centrifugal forces acting ever towards an independent, solitary course, but the centripetal also was there, and they moved with and around their imperial sun,--gracefully or not, willingly or not, as the case might be, but there was no breaking loose: they again, in their own spheres of power, might have their attendant moons, but all were bound to the great massive luminary in the midst.

There is to us a continual mystery in this power of one man over another. We find it acting everywhere, with the simplicity, the ceaselessness, the energy of gravitation; and we may be permitted to speak of this influence as obeying similar conditions; it is proportioned to bulk-for we hold to the notion of a bigness in souls as well as bodies-one soul differing from another in quantity and momentum as well as in quality and force, and its intensity increases by nearriess. There is much in what Jonathan Edwards says of one spiritual essence having more of being than another, and in Dr. Chalmers's question, 'Is he a man of wecht?' 
But when we meet a solar man, of ample naturesoul, body, and spirit; when we find him from his earliest years moving among his fellows like a king, moving them whether they will or not-this feeling of mystery is deepened; and though we would not, like some men (who should know better), worship the creature and convert a hero into a god, we do feel more than in other cases the truth, that it is the inspiration of the Almighty which has given to that man understanding, and that all power, all energy, all light, come to him, from the First and the Lastthe Living One. God comes to be regarded by us, in this instance, as He ought always to be, 'the final centre of repose' - the source of all being, of all life - the Terminus ad quem and the Terminus a quo. And assuredly, as in the firmament that simple law of gravitation reigns supreme-making it indeed a kosmos-majestic, orderly, comely in its goingruling, and binding not the less the fiery and nomadic comets, than the gentle, punctual moons-so certainly, and to us moral creatures to a degree transcendently more important, does the whole intelligent universe move around and move towards and in the Father of Lights.

It would be well if the world would, among the many other uses it makes of its great men, make more of this, - that they are manifestors of Godrevealers of His will-vessels of His omnipotence 
- and are among the very chiefest of His ways and works.

As we have before said, there is a perpetual wonder in this power of one man over his fellows, especially when we meet with it in a great man. You see its operations constantly in history, and through it the Great Ruler has worked out many of His greatest and strangest acts. But however we may understand the accessory conditions by which the one man rules the many, and controls and fashions them to his purposes, and transforms them into his likeness-multiplying as it were himself-there remains at the bottom of it all a mystery - a reaction between body and soul that we cannot explain. Generally, however, we find accompanying its manifestation, a capacious understanding - a strong willan emotional nature, quick, powerful, urgent, undeniable, in perpetual communication with the energetic will and the large resolute intellect-and a strong, hearty, capable body ; a countenance and person expressive of this combination - the mind finding its way at once and in full force to the face, to the gesture, to every act of the body. He must have what is called a 'presence;' not that he must be great in size, beautiful, or strong; but he must be expressive and impressive-his outward man must communicate to the beholder at once and without fail, something of indwelling power, and he must be 
and act as one. You may in your mind analyse him into his several parts; but practically he acts in everything with his whole soul and his whole self; whatsoever his hand finds to do, he does it with his might. Luther, Moses, David, Mahomet, Cromwell -all verified these conditions.

And so did Dr. Chalmers. There was something about his whole air and manner, that disposed you at the very first to make way where he went-he held you before you were aware. That this depended fully as much upon the activity and the quantity-if we may so express ourselves - of his affections, upon that combined action of mind and body which we call temperament, and upon a straightforward, urgent will, as upon what is called the pure intellect, will be generally allowed; but with all this, he could not have been and done, what he was and did, had he not had an understanding, in vigour and in capacity, worthy of its great and ardent companions. It was large and free, mobile, and intense, rather than penetrative, judicial, clear, or fine, -so that in one sense he was more a man to make others act than think; but his own actings had always their origin in some fixed, central, inevitable proposition, as he would call it, and he began his onset with stating plainly, and with lucid calmness, what he held to be a great seminal truth; from this he passed at once, not into exposition, but into illus- 
tration and enforcement-into, if we may make a word, overwhelming insistance. Something was to be done, rather than explained.

There was no separating his thoughts and expressions from his person, and looks, and voice. How perfectly we can at this moment recall him! Thundering, flaming, lightening in the pulpit; teaching, indoctrinating, drawing after him his students in his lecture-room; sitting among other public men, the most unconscious, the most king-like of them all, with that broad leonine countenance, that beaming, liberal smile; or on the way out to his home, in his old-fashioned great-coat, with his throat muffled up, his big walking-stick moved outwards in an arc, its point fixed, its head circumferential, a sort of companion and playmate, with which, doubtless, he demolished legions of imaginary foes, errors, and stupidities in men and things, in Church and State. His great look, large chest, large head, his amplitude every way; his broad, simple, childlike, in-turned feet; his short, hurried, impatient step; his erect, royal air ; his look of general goodwill; his kindling up into a warm but vague benignity when one he did not recognise spoke to him ; the addition, for it was not a change, of keen speciality to his hearty recognition; the twinkle of his eyes; the immediately saying something very personal to set all to rights, and then sending you off with some thought, some feel- 
ing, some remembrance, making your heart burn within you; his voice indescribable; his eye-that most peculiar feature-not vacant, but asleep-innocent, mild, and large ; and his soul, its great inhabitant, not always at his window; but then, when he did awake, how close to you was that burning vehement soul! how it penetrated and overcame you! how mild, and affectionate, and genial its expression at his own fireside !

Of his portraits worth mentioning, there are Watson Gordon's, Duncan's-the Calotypes of Mr. Hill -Kenneth M'Leay's miniatures - the Daguerreotype, and Steell's bust. These are all good, and all give bits of him, some nearly the whole, but not one of them that $\tau \iota \theta \epsilon \rho \mu$ óv, that fiery particle - that inspired look-that 'diviner mind'-the poco piu, or little more. Watson Gordon's is too much of the mere clergyman-is a pleasant likeness, and has the shape of his mouth, and the setting of his feet very good. Duncan's is a work of genius, and is the giant looking up, awakening, but not awakened-it is a very fine picture. Mr. Hill's Calotypes we like better than all the rest; because what in them is true, is absolutely so, and they have some delicate renderings which are all but beyond the power of any human artist; for though man's art is mighty, nature's is mightier. The one of the Doctor sitting with his grandson 'Tommy' is to us the best; we 
have the true grandeur of his form-his bulk. M'Leay's is admirable-spirited-and has that look of shrewdness and vivacity and immediateness which he had when he was observing and speaking keenly; it is moreover, a fine, manly bit of art. M'Leay is the Raeburn of miniature painters-he does a great deal with little. The Daguerreotype is, in its own way, excellent; it gives the externality of the man to perfection, but it is Dr. Chalmers at a stand-still -his mind and feelings 'pulled up' for the second that it was taken. Steell's is a noble bust-has a stern heroic expression and pathetic beauty about it, and from wanting colour and shadow and the eyes, it relies upon a certain simplicity and grandeur;-in this it completely succeeds - the mouth is handled with extraordinary subtlety and sweetness, and the hair hangs over that huge brow like a glorious cloud. We think this head of Dr. Chalmers the artist's greatest bust.

In reference to the assertion we have made as to bulk forming one primary element of a powerful mind, Dr. Chalmers used to say, when a man of activity and public mark was mentioned, 'Has he wecht? he has promptitude-has he power? he has power-has he promptitude? and, moreover, has he a discerning spirit?'

These are great practical, universal truths. How few even of our greatest men have had all these 
three faculties large-fine, sound, and in 'perfect diapason.' Your men of promptitude, without power or judgment, are common and are useful. But they are apt to run wild, to get needlessly brisk, unpleasantly incessant. A weasel is good or bad as the case may be,--good against vermin-bad to meddle with;-but inspired weasels, weasels on a mission, are terrible indeed, mischievous and fell, and swiftness making up for want of momentum by inveteracy; 'fierce as wild bulls, untamable as flies.' Of such men we have now-a-days too many. Men are too much in the way of supposing that doing is being; that theology and excogitation, and fierce dogmatic assertion of what they consider truth, is godliness ; that obedience is merely an occasional great act, and not a series of acts, issuing from a state, like the stream of water from its well.

'Action is transitory-a step-a blow,

The motion of a muscle-this way or that ;

'Tis done-and in the after vacancy,

We wonder at ourselves like men betrayed.

Suffering' (obedience, or being as opposed to doing)-

' Suffering is permanent,

And has the nature of infinity.'

Dr. Chalmers was a man of genius--he had his own way of thinking, and saying, and doing, and looking everything. Men have vexed themselves in vain to define what genius is; like every ultimate term we may describe it by giving its effects, we can 
hardly succeed in reaching its essence. Fortunately, though we know not what are its elements, we know it when we meet it; and in him, in every movement of his mind, in every gesture, we had its unmistakable tokens. Two of the ordinary accompaniments of genius-Enthusiasm and Simplicity-he had in rare measure.

He was an enthusiast in its true and good sense; he was 'entheat,' as if full of God, as the old poets called it. It was this ardour, this superabounding life, this immediateness of thought and action, idea and emotion, setting the whole man agoing at once -that gave a power and a charm to everything he dic. To adopt the old division of the Hebrew Doctors, as given by Nathanael Culverwel, in his

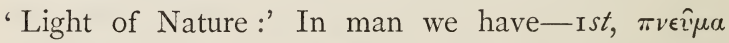

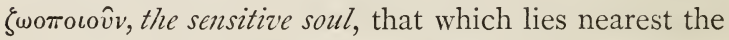
body-the very blossom and flower of life; $2 d$, $\tau \dot{v} v$ vôेv, animam rationis, sparkling and glittering with

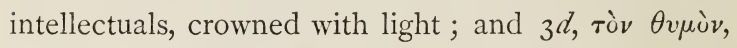
impetum animi, motum mentis, the vigour and energy of the soul - its temper - the mover of the other two-the first being, as they said, resident in hepate - the second in cerebro - the third in corde, where it presides over the issues of life, commands the circulation, and animates and sets the blood a-moving. The first and second are informative, explicative, they 'take in and do'-the other 'gives out.' Now 
in Dr. Chalmers, the great ingredient was the $\dot{0} \theta v \mu$ òs as indicating vis animee et vite, -and in close fellowship with it, and ready for its service, was a large, capacious $\dot{o}$ vov̂s, and an energetic, sensuous, rapid $\tau \grave{~} \pi v \epsilon \hat{v} \mu \alpha$. Hence his energy, his contagious enthusiasm - this it was which gave the peculiar character to his religion, to his politics, to his personnel; everything he did was done heartily-if he desired heavenly blessings, he 'panted' for them' his soul broke for the longing.' To give again the words of the spiritual and subtle Culverwel, 'Religion (and indeed everything else) was no matter of indifferency to him. It was $\lambda \epsilon \rho \mu \grave{\nu} \tau \iota \pi \rho \hat{\alpha} \gamma \mu \alpha$, a certain fiery thing, as Aristotle calls love; it required and it got, the very flower and vigour of the spiritthe strength and sinews of the soul-the prime and top of the affections - this is that grace, that panting grace-we know the name of it and that's all-'tis called zeal-a flaming edge of the affection-the ruddy complexion of the soul.' Closely connected with this temperament, and with a certain keen sensation of truth, rather than a perception of it, if we may so express ourselves, an intense consciousness of objective reality,-was his simple animating faith. He had faith in God-faith in human nature-faith, if we may say so, in his own instincts-in his ideas of men and things-in himself; and the result was, that unhesitating bearing up and steering right on- 
ward-' never bating one jot of heart or hope' so characteristic of him. He had 'the substance of things hoped for.' He had 'the evidence of things not seen.'

By his simplicity we do not mean the simplicity of the head-of that he had none; he was eminently shrewd and knowing-more so than many thought; but we refer to that quality of the heart and of the life, expressed by the words, 'in simplicity a child.' In his own words, from his Daily Readings, -

' When a child is filled with any strong emotion by a surprising event or intelligence, it runs to discharge it on others, impatient of their sympathy ; and it marks, I fancy, the simplicity and greater naturalness of this period (Jacob's), that the grown-up men and women ran to meet each other, giving way to their first impulses-even as children do.'

His emotions were as lively as a child's, and he ran to discharge them. There was in all his ways a certain beautiful unconsciousness of self-an outgoing of the whole nature that we see in children, who are by learned men said to be long ignorant of the EGO -blessed in many respects in their ignorance! This same Ego, as it now exists, being perhaps part of 'the fruit of that forbidden tree ;' that mere knowledge of good as well as of evil, which our great mother bought for us at such a price. In this meaning of the word, Dr. Chalmers, considering the size of his understanding-his personal eminence-his dealings with the world-his large sympathies-his scientific knowledge 
of mind and matter-his relish for the practical details, and for the spirit of public business-was quite singular for his simplicity; and taking this view of it, there was much that was plain and natural in his manner of thinking and acting, which otherwise was obscure and liable to be misunderstood. We cannot better explain what we mean than by giving a passage from Fénélon, which D'Alembert, in his Eloge, quotes as characteristic of that 'sweet-souled' prelate. We give the passage entire, as it seems to us to contain a very beautiful, and by no means commonplace truth :-

'Fénélon,' says D'Alembert, 'a caractérisé lui-même en peu de mots cette simplicité qui le rendoit si cher à tous les cœurs. "La simplicité est la droiture d'une âme qui s'interdit tout retour sur elle et sur ses actions-cette vertu est différente de la sincérité, et la surpasse. On voit beaucoup de gens qui sont sincères sans être simples-Ils ne veulent passer que pour ce qu'ils sont, mais ils craignent sans cesse de passer pour ce qu'ils ne sont pas. L'homme simple n'affecte ni la vertu, ni la vérité même ; il n'est jamais occupé de lui, il semble d'avoir perdu ce moi dont on est si jaloux."'

What delicacy and justness of expression! how true and clear! how little we see now-a-days, among grownup men, of this straightness of the soul-of this losing or never finding 'ce moi!" There is more than is perhaps generally thought in this. Man in a state of perfection, would no sooner think of asking himselfam I right? am I appearing to be what inwardly I am? than the eye asks itself-do I see? or a child 
says to itself-do I love my mother? We have lost this instinctive sense; we have set one portion of ourselves aside to watch the rest; we must keep up appearances and our consistency; we must respectthat is, look back upon-ourselves, and be respected, if possible ; we must, by hook or by crook, be respectable.

Dr. Chalmers would have been a sorry Balaam; he was made of different stuff and for other purposes. Your 'respectable' men are ever doing their best to keep their status, to maintain their position. He never troubled himself about his status; indeed, we would say status was not the word for him. He had a sedes on which he sat, and from which he spoke; he had an imperium, to and fro which he roamed as he listed: but a status was as little in his way as in that of a Mauritanian lion. Your merely 'sincere' men are always thinking of what they said yesterday, and what they may say to-morrow, at the very moment when they should be putting their whole self into to-day. Full of his idea, possessed by it, moved altogether by its power,-believing, he spoke, and without stint or fear, often apparently contradicting his former selfcareless about everything, but speaking fully his mind. One other reason for his apparent inconsistencies was, if one may so express it, the spaciousness of his nature. $\mathrm{He}$ had room in that capacious head, and affection in that great, hospitable heart, for relishing and taking 
in the whole range of human thought and feeling. He was several men in one. Multitudinous but not multiplex, in him odd and apparently incongruous notions dwelt peaceably together. The lion lay down with the lamb. Voluntaryism and an endowment-both were best.

He was childlike in his simplicity: though in understanding a man, he was himself in many things a child. Coleridge says, every man should include all his former selves in his present, as a tree has its former years' growths inside its last; so Dr. Chalmers bore along with him his childhood, his youth, his early and full manhood into his mature old age. This gave himself, we doubt not, infinite delight-multiplied his joys, strengthened and sweetened his whole nature, and kept his heart young and tender,--it enabled him to sympathize, to have a fellow-feeling with all, of whatever age. Those who best knew him, who were most habitually with him, know how beautifully this point of his character shone out in daily, hourly life. We well remember long ago loving him before we had seen him-from our having been told, that being out one Saturday at a friend's house near the Pentlands, he collected all the children and small people-the other bairns, as he called themand with no one else of his own growth, took the lead to the nearest hill-top,- - how he made each take the biggest and roundest stone he could find, and 
carry, - how he panted up the hill himself with one of enormous size,- - how he kept up their hearts, and made them shout with glee, with the light of his countenance, and with all his pleasant and strange ways and words,--how having got the breathless little men and women to the top of the hill, he, hot and scant of breath, looked round on the world and upon them with his broad benignant smile like the $\alpha \nu \eta \dot{\rho} \iota \theta \mu \nu \nu$ $\kappa v \mu \alpha \dot{\tau} \omega \nu \gamma^{\prime} \epsilon \alpha \sigma \mu \alpha$ - the unnumbered laughter of the sea,- - how he set off his own huge 'fellow,'-how he watched him setting out on his race, slowly, stupidly, vaguely at first, almost as if he might die before he began to live, then suddenly giving a spring and off like a shot-bounding, tearing, a $\tilde{\tau} \tau \varsigma$ "

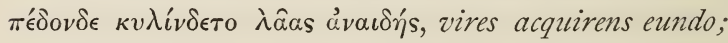
how the great and good man was totus in illo; how he spoke to, upbraided him, cheered him, gloried in him, all but prayed for him,- -how he joked philosophy to his wondering and ecstatic crew, when he (the stone) disappeared among some brackens-telling them they had the evidence of their senses that he was in, they might even know he was there by his effects, by the moving brackens, himself unseen; how plain it became that he had gone in, when he actually came out !- how he ran up the opposite side a bit, and then fell back, and lazily expired at the bottom,how to their astonishment, but not displeasure-for he 'set them off so well,' and 'was so funny'-he 
took from each his cherished stone, and set it off himself! showing them how they all ran alike, yet differently; how he went on, 'making,' as he said, ' an induction of particulars,' till he came to the Benjamin of the flock, a wee wee man, who had brought up a stone bigger than his own big head; then how he let him, unicus omnium, set off his own, and how wonderfully IT ran! what miraculous leaps: what escapes from impossible places: and how it ran up the other side farther than any, and by some felicity remained there.

He was an orator in its specific and highest sense. We need not prove this to those who have heard him; we cannot to those who have not. It was a living man sending living, burning words into the minds and hearts of men before him, radiating his intense fervour upon them all; but there was no reproducing the entire effect wher alone and cool; some one of the elements was gone. We say nothing of this part of his character, because upon this all are agreed. His eloquence rose like a tide, a sea, setting in, bearing down upon you, lifting up all its waves-'deep calling unto deep ;' there was no doing anything but giving yourself up for the time to its will. Do our readers remember Horace's description of Pindar?

'Monte decurrens velut amnis, imbres

Quem super notas aluere ripas, Fervet immensusque ruit profundo Pindarus ore : 
_ "per audaces nova dithyrambos

Verba devolvit, numerisque fertur

Lege solutis." ,

This is to our mind singularly characteristic of our perfervid Scotsman. If we may indulge our conceit, we would paraphrase it thus. His eloquence was like a flooded Scottish river,--it had its origin in some exalted region-in some mountain-truth-some high, immutable reality; it did not rise in a plain, and quietly drain its waters to the sea,-it came sheer down from above. He laid hold of some simple truth-the love of God, the Divine method of justification, the unchangeableness of human nature, the supremacy of conscience, the honourableness of all men; and having got this vividly before his mind, on he moved-the river rose at once, drawing everything into its course-

'All thoughts, all passions, all delights,-

Whatever stirs this mortal frame,'

things outward and things inward, interests immediate and remote-God and eternity-men, miserable and immortal-this world and the next-clear light and unsearchable mystery - the word and the works of God-everything contributed to swell the volume and add to the onward and widening flood. His river did not flow like Denham's Thames,-

'Though deep yet clear, though gentle yet not dull ;

Strong without rage, without o'erflowing full.'

There was strength, but there was likewise rage; a 


\section{Dr. Chalmers.}

fine frenzy-not unoften due mainly to its rapidity and to its being raised suddenly by his affections; there was some confusion in the stream of his thoughts, some overflowing of the banks, some turbulence, and a certain noble immensity; but its origin was clear and calm, above the region of clouds and storms. If you saw it; if you took up and admitted his proposition, his starting idea, then all else moved on ; but once set agoing, once on his way, there was no pausing to inquire, why or how-fervet-ruit-fertur, he boils-he rushes-he is borne along; and so are all who hear him.

To go on with our figure-There was no possibility of sailing up his stream. You must go with him, or you must go ashore. This was a great peculiarity with him, and puzzled many people. You could argue with him, and get him to entertain your ideas on any purely abstract or simple proposition,-at least for a time; but once let him get down among practicals, among applications of principles, into the regions of the affections and active powers, and such was the fervour and impetuosity of his nature, that he could not stay leisurely to discuss, he could not then entertain the opposite; it was hurried off, and made light of, and disregarded, like a floating thing before a cataract.

To play a little more with our conceit-The greatest man is he who is both born and made-who is at 
once poetical and scientific - who has genius and talent-each supporting the other. So with rivers. Your mighty world's river rises in high and lonely places, among the everlasting hills; amidst clouds, or inaccessible clearness. On he moves, gathering to himself all waters; refreshing, cheering all lands. Here a cataract, there a rapid; now lingering in some corner of beauty, as if loath to go. Now shallow and wide, rippling and laughing in his glee; now deep, silent, and slow; now narrow and rapid and deep, and not to be meddled with. Now in the open country; not so clear, for other waters have come in upon him, and he is becoming useful, no longer turbulent,travelling more contentedly; now he is navigable, craft of all kinds coming and going upon his surface for ever; and then, as if by some gentle and great necessity, 'deep and smooth, passing with a still foot and a sober face,' he pays his last tribute to 'the Fiscus, the great Exchequer, the sea'-running out fresh, by reason of his power and volume, into the main for many a league.

Your mere genius, who has instincts, and is poetical and not scientific, who grows from within-he is like our mountain river, clear, wilful, odd; running round corners ; disappearing it may be underground, coming up again quite unexpectedly and strong, as if fed from some unseen spring, deep down in darkness; rising in flood without warning, and coming down 
like a lion; often all but dry; never to be trusted to for driving mills ; must at least be tamed and led off to the mill; and going down full pace, and without stop or stay, into the sea.

Your man of talent, of acquirements, of sciencewho is made, - who is not so much educed as edified; who, instead of acquiring his vires eundo, gets his vires eundi, from acquirement, and grows from without; who serves his brethren and is useful; he rises often no one knows where or cares; has perhaps no proper fountain at all, but is the result of the gathered rain-water in the higher flats; he is never quite clear, never brisk, never dangerous; always from the first useful, and goes pleasantly in harness; turns mills; washes rags-makes them into paper; carries down all manner of dye-stuffs and feculence; and turns a bread-mill to as good purpose as any clearer stream; is docile, and has, as he reaches the sea, in his dealings with the world, a river trust, who look after his and their own interests, and dredge him, and deepen him, and manage him, and turn him off into docks, and he is in the sea before he or you know it.

Though we do not reckon the imagination of Dr. Chalmers among his master faculties, it was powerful, effective, magnificent. It did not move him, he took it up as he went along; it was not that imperial, penetrating, transmuting function that we find it in 
Dante, in Jeremy Taylor, in Milton, or in Burke; he used it to emblazon his great central truths, to hang clouds of glory on the skirts of his illustration; but it was too passionate, too material, too encumbered with images, too involved in the general mêlée of the soul, to do its work as a master. It was not in him, as Thomas Fuller calls it, 'that inward sense of the soul, its most boundless and restless faculty; for while the understanding and the will are kept, as it were, in liberâa custodia to their objects of verum et bonum, it is free from all engagements-digs without spade, flies without wings, builds without charges, in a moment striding from the centre to the circumference of the world by a kind of omnipotency, creating and annihilating things in an instant-restless, ever working, never wearied.' We may say, indeed, that men of his temperament are not generally endowed with this power in largest measure; in one sense they can do without it, in another they want the conditions on which its highest exercise depends. Plato and Milton, Shakspere and Dante and Wordsworth, had imaginations tranquil, sedate, cool, originative, penetrative, intense, which dwelt in the 'highest heaven of invention.' Hence it was that Chalmers could personify or paint a passion; he could give it in one of its actions; he could not, or rather he never did impassionate, create, and vivify a person - a very different thing from personifying a 
passion - all the difference, as Henry Taylor says, between Byron and Shakspere.

In his impetuosity, we find the rationale of much that is peculiar in the style of Dr. Chalmers. As a spoken style it was thoroughly effective. ${ }^{1}$ He seized the nearest weapons, and smote down whatever he hit. But from this very vehemence, this haste, there was in his general style a want of correctness, of selectness, of nicety, of that curious felicity which makes thought immortal, and enshrines it in imperishable crystal. In the language of the affections he was singularly happy; but in a formal statement, rapid argumentation and analysis, he was often as we

${ }^{1}$ We have not noticed his iterativeness, his reiterativeness, because it flowed naturally from his primary qualities. In speaking it was effective, and to us pleasing, because there was some new modulation, some addition in the manner, just as the sea never sets up one wave exactly like the last or the next. But in his books it did somewhere encumber his thoughts, and the reader's progress and profit. It did not arise, as in many lesser men, from his having said his say-from his having no more in him ; much less did it arise from conceit, either of his idea or of his way of stating it ; but from the intensity with which the sensation of the idea-if we may use the expressionmade its first mark on his mind. Truth to him never seemed to lose its first freshness, its edge, its flavour ; and Divine truth, we know, had come to him so suddenly, so fully, at mid-day, when he was in the very prime of his knowledge and his power and quickness-had so possessed his entire nature, as if, like him who was journeying to Damascus, a Great Light had shone round about him-that whenever he reproduced that condition, he began afresh, and with his whole utterance, to proclaim it. He could not but speak the things he had seen and felt, and 
might think, uncouth, and imperfect, and incorrect : chiefly owing to his temperament, to his fiery, impatient, swelling spirit, this gave his orations their fine audacity - this brought out hot from the furnace, his new words - this made his numbers run wildlege solutis. We are sure this view will be found confirmed by these 'Daily Readings,' when he wrote little, and had not time to get heated, and when the nature of the work, the hour at which it was done, and his solitariness, made his thoughts flow at their 'own sweet will ;' they are often quite as classical in expression, as they are deep and lucid in thoughtreflecting heaven with its clouds and stars, and letting us see deep down into its own secret depths : this is

lieard and believed; and he did it much in the same way, and in the same words, for the thoughts and affections and posture of his soul were the same. Like all men of vivid perception and keen sensibility, his mind and his body continued under impressions, both material and spiritual, after the objects were gone. A curious instance of this occurs to us. Some years ago, he roamed up and clown through the woods near Auchindinny, with two boys as companions. It was the first burst of summer, and the trees were more than usually enriched with leaves. He wandered about delighted, silent, looking at the leaves, 'thick and numberless.' As the three went on, they came suddenly upon a high brick wall, newly built, for peach trees, not yet planted. Dr. Chalmers halted, and looking steadfastly at the wall, exclaimed most earnestly, "What foliage! what foliage!' The boys looked at one another, and said nothing; but on getting home, expressed their astonishment at this very puzzling phenomenon. What a difference! leaves and parallelograms ; a forest and a brick wall ! 
to us one great charm of these volumes. Here he is broad and calm; in his great public performances by mouth and pen, he soon passed from the lucid into the luminous.

What, for instance, can be finer in expression than this? 'It is well to be conversant with great elements-life and death, reason and madness.' 'God forgets not his own purposes, though he executes them in his own way, and maintains his own pace, which he hastens not and shortens not to meet our impatience.' 'I find it easier to apprehend the greatness of the Deity than any of his moral perfections, or his sacredness ;' and this-

' One cannot but feel an interest in Ishmael-figuring him to be a noble of nature-one of those heroes of the wilderness who lived on the produce of his bow, and whose spirit was nursed and exercised among the wild adventures of the life that he led. And it does soften our conception of him whose hand was against every man, and every man's hand against him, when we read of his mother's influence over him, in the deference of Ishmael to whom we read another example of the respect yielded to females even in that so-called barbarous period of the world. There was a civilisation, the immediate effect of religion in these days, from which men fell away as the world grew older.'

That he had a keen relish for material and moral beauty and grandeur we all know; what follows shows that he had also the true ear for beautiful words, as at once pleasant to the ear and suggestive of some higher feelings : ' $\mathrm{I}$ have often felt, in read- 
ing Milton and Thomson, a strong poetical effect in the bare enumeration of different countries, and this strongly enhanced by the statement of some common and prevailing emotion, which passed from one to another.' This is set forth with great beauty and power in verses I4th and I5th of Exodus xv.,'The people shall hear and be afraid-sorrow shall take hold on the inhabitants of Palestina. Then the dukes of Edom shall be amazed-the mighty men of Moab, trembling shall take hold of them-the inhabitants of Canaan shall melt away.' Any one who has a tolerable ear and any sensibility, must remember the sensation of delight in the mere sound-like the colours of a butterfly's wing, or the shapeless glories of evening clouds, to the eye-in reading aloud such passages as these: "Heshbon shall cry and Elealeh : their voice shall be heard to Jahaz: for by the way of Luhith with weeping shall they go it up ; for in the way of Horonaim they shall raise a cry.-God came from Teman, the Holy One from Mount Paran.-Is not Calno as Carchemish? is not Hamath as Arpad? is not Samaria as Damascus? $\mathrm{He}$ is come to Aiath, he is passed to Migron; at Michmash he hath laid up his carriages : Ramah is afraid ; Gibeah of Saul is fled. Lift up thy voice, O daughter of Gallim : cause it to be heard unto Laish, O poor Anathoth! Madmenah is removed; the inhabitants of Gebim gather themselves to flee.-The 
fields of Heshbon languish, the vine of Sibmah; I will water thee with my tears, O Heshbon and Elealeh.' Any one may prove to himself that much of the effect and beauty of these passages depends on these names; put others in their room, and try them.

We remember well our first hearing Dr. Chalmers. We were in a moorland district in Tweeddale, rejoicing in the country, after nine months of the High School. We heard that the famous preacher was to be at a neighbouring parish church, and off we set, a cartful of irrepressible youngsters. 'Calm was all nature as a resting wheel.' The crows, instead of making wing, were impudent and sat still; the carthorses were standing, knowing the day, at the fieldgates, gossiping and gazing, idle and happy; the moor was stretching away in the pale sunlight vast, dim, melancholy, like a sea; everywhere were to be seen the gathering people, 'sprinklings of blithe company;' the country-side seemed moving to one centre. As we entered the kirk we saw a notorious character, a drover, who had much of the brutal look of what he worked in, with the knowing eye of a man of the city, a sort of big Peter Bell-

'He had a hardness in his eye, He had a hardness in his cheek.'

He was our terror, and we not only wondered, but were afraid when we saw him going in. The kirk was full as it could hold. How different in looks 
to a brisk town congregation! There was a fine leisureliness and vague stare; all the dignity and vacancy of animals; eyebrows raised and mouths open, as is the habit with those who speak little and look much, and at far-off objects. The minister comes in, homely in his dress and gait, but having a great look about him, like a mountain among hills. The High School boys thought him like a 'big one of ourselves,' he looks vaguely round upon his audience, as if he saw in it one great object, not many. We shall never forget his smile! its general benignity;- -how he let the light of his countenance fall on us! He read a few verses quietly; then prayed briefly, solemnly, with his eyes wide open all the time, but not seeing. Then he gave out his text; we forget it, but its subject was, 'Death reigns.' He stated slowly, calmly, the simple meaning of the words; what death was, and how and why it reigned; then suddenly he started, and looked like a man who had seen some great sight, and was breathless to declare it; he told us how death reigned everywhere, at all times, in all places; how we all knew it, how we would yet know more of it. The drover, who had sat down in the table-seat opposite, was gazing up in a state of stupid excitement; he seemed restless, but never kept his eye from the speaker. The tide set in-everything added to its power, deep called to deep, imagery and illustra- 
tion poured in; and every now and then the theme, - the simple, terrible statement, was repeated in some lucid interval. After overwhelming us with proofs of the reign of Death, and transferring to us his intense urgency and emotion ; and after shrieking, as if in despair, these words, 'Death is a tremendous necessity,'- -he suddenly looked beyond us as if into some distant region, and cried out, 'Behold a mightier !-who is this? He cometh from Edom, with dyed garments from Bozrah, glorious in his apparel, speaking in righteousness, travelling in the greatness of his strength, mighty to save." Then, in a few plain sentences, he stated the truth as to sin entering, and death by sin, and death passing upon all. Then he took fire once more, and enforced, with redoubled energy and richness, the freeness, the simplicity, the security, the sufficiency of the great method of justification. How astonished and impressed we all were! He was at the full thunder of his power; the whole man was in an agony of earnestness. The drover was weeping like a child, the tears running down his ruddy, coarse cheeks-his face opened out and smoothed like an infant's; his whole body stirred with emotion. We all had insensibly been drawn out of our seats, and were converging towards the wonderful speaker. And when he sat down, after warning each one of us to remember who it was, and what it was, that 
followed death on his pale horse, ${ }^{1}$ and how alone we could escape-we all sunk back into our seats. How beautiful to our eyes did the thunderer lookexhausted-but sweet and pure! How he poured out his soul before his God in giving thanks for sending the Abolisher of Death! Then a short psalm, and all was ended.

We went home quieter than we came; we did not recount the foals with their long legs, and roguish eyes, and their sedate mothers; we did not speculate whose dog that was, and whether that was a crow or a man in the dim moor,-we thought of other things. That voice, that face; those great, simple, living thoughts; those floods of resistless eloquence; that piercing, shattering voice, - that ' tremendous necessity.'

Were we desirous of giving to one who had never seen or heard Dr. Chalmers an idea of what manner of man he was-what he was as a whole, in the full round of his notions, tastes, affections, and powers, we would put this book into their hands, and ask them to read it slowly, bit by bit, as he wrote it. In it he puts down simply, and at once, what passes through his mind as he reads; there is no making of

1 'And I looked, and behold a pale horse ; and his name that sat on him was Death, and Hell followed with him.'-Rev. vi. 8 . 
himself feel and think-no getting into a frame of mind; he was not given to frames of mind; he preferred states to forms-substances to circumstances. There is something of everything in it-his relish for abstract thought-his love of taking soundings in deep places and finding no bottom-his knack of starting subtle questions, which he did not care to run to earth-his penetrating, regulating godlinesshis delight in nature-his turn for politics, general. economical, and ecclesiastical-his picturesque eyehis humanity-his courtesy-his warm-heartednesshis impetuosity-his sympathy with all the wants, pleasures, and sorrows of his kind-his delight in the law of God, and his simple, devout, manly treatment of it-his acknowledgment of difficulties-his turn for the sciences of quantity and number, and indeed for natural science and art generally-his shrewdness -his worldly wisdom-his genius; all these come out-you gather them like fruit, here a little, and there a little. He goes over the Bible, not as a philosopher, or a theologian, or a historian, or a geologist, or a jurist, or a naturalist, or a statist, or a politician -picking out all that he wants, and a great deal more than he has any business with, and leaving everything else as barren to his reader as it has been to himself; but he looks abroad upon his Father's word - as he used so pleasantly to do on his worldas a man, and as a Christian; he submits himself to 
its influences, and lets his mind go out fully and naturally in its utterances. It is this which gives to this work all the charm of multitude in unity, of variety in harmony; and that sort of unexpectedness and ease of movement which we see everywhere in nature and in natural men.

Our readers will find in these delightful Bible Readings not a museum of antiquities, and curiosities, and laborious trifles; nor of scientific specimens, analysed to the last degree, all standing in order, labelled and useless. They will not find in it an armoury of weapons for fighting with and destroying their neighbours. They will get less of the physic of controversy than of the diet of holy living. They will find much of what Lord Bacon desired, when he said, 'We want short, sound, and judicious notes upon Scripture, without running into commonplaces, pursuing controversies, or reducing those notes to artificial method, but leaving them quite loose and native. For certainly, as those wines which flow from the first treading of the grape are sweeter and better than those forced out by the press, which gives them the roughness of the husk and the stone, so are those doctrines best and sweetest which flow from a gentle crush of the Scriptures, and are not wrung into controversies and commonplaces.' They will find it as a large pleasant garden; no great system; not trim, but beautiful, and in which there are things 


\section{Dr. Chalmers.}

pleasant to the eye as well as good for food-flowers and fruits, and a few good esculent, wholesome roots. There are Honesty, Thrift, Eye-bright (Euphrasy that cleanses the sight), Heart's-ease. The good seed in abundance, and the strange mystical Passion-flower; and in the midst, and seen everywhere, if we but look for it, the Tree of Life, with its twelve manner of fruits - the very leaves of which are for the healing of the nations. And, perchance, when they take their walk through it at evening-time, or at 'the sweet hour of prime,' they may see a happy, wise, beaming old man at his work there-they may hear his wellknown voice; and if they have their spiritual senses exercised as they ought, they will not fail to see by his side 'one like unto the Son of Man.' 

DR. GEORGE WILSON. 



\section{DR. GEORGE WILSON.}

A MONG the many students at our University who some two-and-twenty years ago started on the great race, in the full flush of youth and health, and with that strong hunger for knowledge which only the young, or those who keep themselves so, ever know, there were three lads-Edward Forbes, Samuel Brown, and George Wilson-who soon moved on to the front and took the lead. They are now all three in their graves.

No three minds could well have been more diverse in constitution or bias; each was typical of a generic difference from the others. What they cordially agreed in, was their hunting in the same field and for the same game. The truth about this visible world, and all that it contains, was their quarry. This one thing they set themselves to do, but each had his own special gift, and took his own roadeach had his own special choice of instruments and means. Any one man combining their essential 
powers, would have been the epitome of a natural philosopher, in the wide sense of the man who would master the philosophy of nature.

Edward Forbes, who bulks largest at present, and deservedly, for largeness was of his essence, was the observer proper. He saw everything under the broad and searching light of day, white and uncoloured, and with an unimpassioned eye. What he was after were the real appearances of things; phenomena as such; all that seems to be. His was the search after what is, over the great field of the world. He was in the best sense a natural historian, an observer and recorder of what is seen and of what goes on, and not less of what has been seen and what has gone on, in this wonderful historic earth of ours, with all its fulness. He was keen, exact, capacious,- - tranquil and steady in his gaze as nature herself. He was, thus far, kindred to Aristotle, to Pliny, Linnæus, Cuvier, and Humboldt, though the great German, and the greater Stagirite, had higher and deeper spiritual insights than Edward Forbes ever gave signs of. It is worth remembering that Dr. George Wilson was up to his death engaged in preparing his Memoir and Remains for the press. Who will now take up the tale?

Samuel Brown was, so to speak, at the opposite pole-rapid, impatient, fearless, full of passion and imaginative power-desiring to divine the essences 


\section{Dr. George Wilson.}

rather than the appearances of things-in search of the what chiefly in order to question it, make it give up at whatever cost the secret of its why; his fiery, projective, subtle spirit, could not linger in the outer fields of mere observation, though he had a quite rare faculty for seeing as well as for looking, which latter act, however, he greatly preferred; but he pushed into the heart and inner life of every question, eager to evoke from it the very secret of itself. Forbes, as we have said, wandered at will, and with a settled purpose and a fine hunting scent, at his leisure, and free and almost indifferent, over the ample fields-happy and joyous and full of workunencumbered with theory or with wings, for he cared not to fly. Samuel Brown, whose wings were perhaps sometimes too much for him, more ambitious, more of a solitary turn, was for ever climbing the Mount Sinais and Pisgahs of science, to speak with Him whose haunt they were,-Climbing there all alone and in the dark, and with much peril, if haply he might descry the break of day and the promised land; or, to vary the figure, diving into deep and not undangerous wells, that he might the better see the stars at noon, and possibly find $\mathrm{Her}$ who is said to lurk there. He had more of Plato, though he wanted the symmetry and persistent grandeur of the son of Ariston. He was perhaps liker his own favourite Kepler; such a man in a word as we have 
not seen since Sir Humphry Davy, whom in many things he curiously resembled, and not the least in this, that the prose of each was more poetical than the verse.

His fate has been a mournful and a strange one, but he knew it, and encountered it with a full knowledge of what it entailed. He perilled everything on his theory; and if this hypothesis-it may be somewhat prematurely uttered to the world, and the full working out of which, by rigid scientific realization, was denied him by years of intense and incapacitating suffering, ending only in death, but the 'relevancy' of which, to use the happy expression of Dr. Chalmers, we hold him to have proved, and in giving a glimpse of which, he showed, we firmly believe, what has been called that 'instinctive grasp which the healthy imagination takes of possible truth,'-if his theory of the unity of matter, and the consequent transmutability of the now called elementary bodies, were substantiated in the lower but essential platform of actual experiment, this, along with his original doctrine of atoms and their forces, would change the entire face of chemistry, and make a Cosmos where now there is endless agglomeration and confusion,- - would, in a word, do for the science of the molecular constitution of matter and its laws of action and reaction at insensible distances, what Newton's doctrine of gravitation has done for the 


\section{Dr. George Wilson.}

celestial dynamics. For, let it be remembered, that the highest speculation and proof in this department -by such men as Dumas, Faraday, and William Thomson, and others-points in this direction; it does no more as yet perhaps than point, but some of us may live to see 'resurgam' inscribed over Samuel Brown's untimely grave, and applied with gratitude and honour to him whose eyes closed in darkness on the one great object of his life, and the hopes of whose ' unaccomplished years' lie buried with him.

Very different from either, though worthy of and capable of relishing much that was greatest and best in both, was he whom we all loved and mourn, and who, this day week, ${ }^{1}$ was carried by such a multitude of mourners to that grave, which to his eye had been open and ready for years.

George Wilson was born in Edinburgh in r8r8. His father, Mr. Archibald Wilson, was a wine merchant, and died sixteen years ago; his mother, Janet Aitken, still lives to mourn and to remember him, and she will agree with us that it is sweeter to remember him than to have converse with the rest. Any one who has had the privilege to know him, and to enjoy his bright and rich and beautiful mind, will not need to go far to learn where it was that her son George got all of that genius and worth and delightfulness which is transmissible. She verifies

1 Monday, 28th November 1859. 
what is so often and so truly said of the mothers of remarkable men. She was his first and best Alma Mater, and in many senses his last, for her influence over him continued through life. George had a twin brother, who died in early life; and we cannot help referring to his being one of twins, something of that wonderful faculty of attracting and being personally loved by those about him, which was one of his strongest as it was one of his most winning powers. He was always fond of books, and of fun, the play of the mind. He left the High School at fifteen and took to medicine; but he soon singled out chemistry, and, under the late Kenneth Kemp, and our own distinguished Professor of Materia Medica, himself a first-class chemist, he acquired such knowledge as to become assistant in the laboratory of Dr. Thomas Graham, then Professor of Chemistry in. University College, and now Master of the Mint. So he came out of a thorough and good school, and had the best of masters.

He then took the degree of M.D., and became a Lecturer on Chemistry, in what is now called the extra-academical school of medicine, but which in our day was satisfied with the title of private lecturers. He became at once a great favourite, and, had his health and strength enabled him, he would have been long a most successful and popular tcacher; but general feeble health, and a disease 
in the ankle-joint requiring partial amputation of the foot, and recurrent attacks of a serious kind in his lungs, made his life of public teaching one long and sad trial. How nobly, how sweetly, how cheerily he bore all these long baffling years; how his bright, active, ardent, unsparing soul lorded it over his frail but willing body, making it do more than seemed possible, and as it were by sheer force of will ordering it to live longer than was in it to do, those who lived with him and witnessed this triumph of spirit over matter, will not soon forget. It was a lesson to every one of what true goodness of nature, elevated and cheered by the highest and happiest of all motives, can make a man endure, achieve, and enjoy.

As is well known, Dr. Wilson was appointed in I 855 to the newly-constituted Professorship of Technology, and to the Curatorship of the Industrial Museum. The expenditure of thought, of ingenuity, of research and management-the expenditure, in a word, of himself-involved in originating and giving form of purpose to a scheme so new and so undefined, and, in our view, so undefinable, must, we fear, have shortened his life, and withdrawn his precious and quite singular powers of illustrating and adorning, and, in the highest sense, sanctifying and blessing science, from this which seemed always to us his proper sphere. Indeed, in the opinion of some good judges, the institution of such a chair at 
all, and especially in connexion with a University such as ours, and the attaching to it the conduct of a great Museum of the Industrial Arts, was somewhat hastily gone into, and might have with advantage waited for and obtained a little more consideration and forethought. Be this as it may, Dr. Wilson did his duty with his whole heart and soul-making a class, which was always increasing, and which was at its largest at his death.

We have left ourselves no space to speak of Dr. Wilson as an author, as an academic and popular lecturer, as a member of learned societies, as a man of exquisite literary powers and fancy, and as a citizen of remarkable public acceptation. This must come from some more careful, and fuller, and more leisurely record of his genius and worth. What he was as a friend it is not for us to say; we only know that when we leave this world we would desire no better memorial than to be remembered by many as George Wilson now is, and always will be. His Life of Cavendish is admirable as a biography, full of life, of picturesque touches, and of realization of the man and of his times, and is, moreover, thoroughly scientific, containing, among other discussions, by far the best account of the great water controversy from the Cavendish point of view. His Life of John Reid is a vivid and memorable presentation to the world of the true lineaments, manner 
of life, and inmost thought and heroic sufferings, as well as of the noble scientific achievements of that strong, truthful, courageous, and altogether admirable man, and true discoverer - a genuine follower of John Hunter.

The Five Gateways of Knowledge is a prose poem, a hymn of the finest utterance and fancy-the white light of science diffracted through the crystalline prism of his mind into the coloured glories of the spectrum ; truth dressed in the iridescent hues of the rainbow, and not the less but all the more true. His other papers in the British Quarterly, the North British Retieze, and his last gem on 'Paper, Pens, and Ink, in his valued and generous friend Macmillan's first number of his Magazine, are all astonishing proofs of the brightness, accuracy, vivacity, unweariedness of his mind, and the endless sympathy and affectionate play of his affections with the full round of scientific truth. His essay on 'Colour Blindness' is, we believe, as perfect a monogram as exists, and will remain likely untouched and unadded to, factum ad unguem. As may be seen from these remarks, we regard him not so much as, like Edward Forbes; a great observer and quiet generalizer, or, like Samuel Brown, a discoverer and philosopher properly so called - though, as we have said, he had enough of these two men's prime qualities to understand and relish and admire them. His 
great quality lay in making men love ascertained and recorded truth, scientific truth especially; he made his reader and hearer enjoy facts. He illuminated the Book of Nature as they did the missals of old. His nature was so thoroughly composite, so in full harmony with itself, that no one faculty could or cared to act without calling in all the others to join in full chorus. To take an illustration from his own science, his faculties interpenetrated and interfused themselves into each other, as the gases do, by a law of their nature. Thus it was that everybody understood and liked and was impressed by him; he touched them at every point. Knowledge was to him no barren, cold essence: it was alive and flushed with the colours of the earth and sky, and all over with light and stars. His flowers-and his mind was full of flowers-were from seeds, and were sown by himself. They were neither taken from other gardens and stuck in rootless, as children do, much less were they of the nature of gumflowers, made with hands, wretched and dry and scentless.

Truth of science was to him a body, full of loveliness, perfection, and strength, in which dwelt the unspeakable Eternal. This, which was the dominant idea of his mind-the goodliness, and not less the godliness of all science-made his whole life, his every action, every letter he wrote, every lecture he delivered, his last expiring breath, instinct with the 


\section{Dr. George Wilson.}

one constant idea that all truth, all goodness, all science, all beauty, all gladness, are but the expression of the mind and will and heart of the Great Supreme. And this, in his case, was not mysticism, neither was it merely a belief in revealed religion, though no man cherished and believed in his Bible more firmly and cordially than he ; it was the assured belief, on purely scientific grounds, that God is indeed and in very truth all in all; that, to use the sublime adaptation by poor crazy Smart, the whole creation, visible and invisible, spiritual and material, everything that has being, is-to those who have ears to hear--for ever declaring ' Thou Art,' before the throne of the Great I AM.

To George Wilson, to all such men-and this is the great lesson of his life-the heavens are for ever telling His glory, the firmament is for ever showing forth His handiwork; day unto day, every day, is for ever uttering speech, and night unto night is showing knowledge concerning Him. When he considered these heavens, as he lay awake, weary, and in pain, they were to him the work of His fingers. The morn, walking in brightness, and lying in white glory on his bed-the stars-were by Him ordained. He was a singularly happy, and happy-making man. No one since his boyhood could have suffered more from pain, and languor, and the misery of an unable body. Yet he was not only cheerful, he was gay, full of all sorts 
of fun-genuine fun-and his jokes and queer turns of thought and word were often worthy of Cowper or Charles Lamb. We wish we had them collected. Being, from his state of health and his knowledge in medicine, necessarily 'mindful of death,' having the possibility of his dying any day or any hour, always before him, and that ' undiscovered country' lying full in his view, he must, taking, as he did, the right notion of the nature of things-have had a peculiar intensity of pleasure in the every-day beauties of the world.

'The common sun, the air, the skies, To him were opening Paradise.'

They were to him all the more exquisite, all the more altogether lovely, these Pentlands and the Braid Hills, and all his accustomed drives and places; these rural solitudes and pleasant villages and farms, and the countenances of his friends, and the clear, pure, radiant face of science and of nature, were to him all the more to be desired and blessed and thankful for, that he knew the pallid king at any time might give that not unexpected knock, and summon him away. 


\section{HER LAST HALF-CROWN.}

' Once I had friends-though now by all forsaken; Once I had parents - they are now in heaven. I had a home once-_

Worn out with anguish, sin, and cold, and hunger, Down sunk the outcast, death had seized her senses. There did the stranger find her in the morning-God had neleased her.

SOUTHEY. 



\section{HER LAST HALF-CROWN.}

HUGH MILLER, the geologist, journalist, and man of genius, was sitting in his newspaper office late one dreary winter night. The clerks had all left, and he was preparing to go, when a quick rap came to the door. He said 'Come in,' and, looking towards the entrance, saw a little ragged child all wet with sleet. 'Are ye Hugh Miller?' 'Yes.' 'Mary Duff wants ye.' 'What does she want?' 'She 's deein'.' Some misty recollection of the name made him at once set out, and with his well-known plaid and stick, he was soon striding after the child, who trotted through the now deserted High Street, into the Canongate. By the time he got to the Old Playhouse Close, Hugh had revived his memory of Mary Duff; a lively girl who had been bred up beside him in Cromarty. The last time he had seen her was at a brother mason's marriage, where Mary was 'best naaid,' and he 'best man.' He seemed still to see her bright young careless face, her tidy 
shortgown, and her dark eyes, and to hear her bantering, merry tongue.

Down the close went the ragged little woman, and up an outside stair, Hugh keeping near her with difficulty; in the passage she held out her hand and touched him; taking it in his great palm, he felt that she wanted a thumb. Finding her way like a cat through the darkness, she opened a door, and saying, 'That's her !' vanished. By the light of a dying fire he saw lying in the corner of the large empty room something like a woman's clothes, and on drawing nearer became aware of a thin pale face and two dark eyes looking keenly but helplessly up at him. The eyes were plainly Mary Duff's, though he could recognise no other feature. She wept silently, gazing steadily at him. 'Are you Mary Duff?' 'It's a' that's o' me, Hugh.' She then tried to speak to him, something plainly of great urgency, but she couldn't ; and seeing that she was very ill, and was making herself worse, he put half-a-crown into her feverish hand, and said he would call again in the morning. $\mathrm{He}$ could get no information about her from the neighbours : they were surly or asleep.

When he returned next morning, the little girl met him at the stair-head, and said, 'She's deid.' He went in, and found that it was true; there she lay, the fire out, her face placid, and the likeness to her maiden self restored. Hugh thought he would have 


\section{Her Last Half-Crown.}

known her now, even with those bright black eyes closed as they were, in cternum.

Seeking out a neighbour, he said he would like to bury Mary Duff, and arranged for the funeral with an undertaker in the close. Little seemed to be known of the poor outcast, except that she was a 'licht,' or, as Solomon would have said, a 'strange woman.' 'Did she drink?' 'Whiles.'

On the day of the funeral one or two residents in the close accompanied him to the Canongate Churchyard. He observed a decent-looking little old woman watching them, and following at a distance, though the day was wet and bitter. After the grave was filled, and he had taken off his hat, as the men finished their business by putting on and slapping the sod, he saw this old woman remaining; she came up and, courtesying, said, 'Ye wad ken that lass, Sir?' 'Yes; I knew her when she was young.' The woman then burst into tears, and told Hugh that she 'keepit a bit shop at the close-mooth, and Mary dealt wi' me, and aye paid reglar, and I was feared she was dead, for she had been a month awin' me half-acrown :' and then, with a look and voice of awe, she told him how on the night he was sent for, and immediately after he had left, she had been awakened by some one in her room; and by her bright firefor she was a bein, well-to-do body-she had seen the wasted dying creature, who came forward and said, 
'Wasn't it half-a-crown?' 'Yes.' 'There it is,' and putting it under the bolster, vanished!

Poor Mary Duff! her life had been a sad one since the day when she had stood side by side with Hugh at the wedding of their friends. Her father died not long after, and her mother supplanted her in the affections of the man to whom she had given her heart. The shock made home intolerable. She fled from it blighted and embittered, and after a life of shame and misery, crept into the corner of her room to die alone.

'My thoughts are not your thoughts, neither are your ways my ways, saith the Lord. For as the heavens are higher than the earth, so are my ways higher than your ways, and my thoughts than your thoughts.' 
QUEEN MARY'S CHILD-GARDEN. 



\section{QUEEN MARY'S CHILD-GARDEN.}

I F any one wants a pleasure that is sure to please, one over which he needn't growl the sardonic beatitude of the great Dean, let him, when the Mercury is at 'Fair,' take the nine A.M. train to the North, and a return ticket for Callander, and when he arrives at Stirling, let him ask the most obliging and knowing of station-masters to telegraph to 'the Dreadnought' for a carriage to be in waiting. When passing Dunblane Cathedral, let him resolve to write to the Scotsman, advising the removal of a couple of shabby trees which obstruct the view of that beautiful triple end-window which Mr. Ruskin and everybody else admires, and by the time he has written this letter in his mind, and turned the sentences to it, he will find himself at Callander and the carriage all ready. Giving the order for the Port of Monteith, he will rattle through this hard-featured, and to our eye comfortless village, lying ugly amid so much grandeur and beauty, and let him stop on the crown 
of the bridge, and fill his eyes with the perfection of the view up the Pass of Leny-the Teith lying diffuse and asleep, as if its heart were in the Highlands and it were loath to go, the noble Ben Ledi imaged in its broad stream. Then let him make his way across a bit of pleasant moorland-flushed with maiden-hair and white with cotton-grass; and fragrant with the Orchis conopsia, well deserving its epithet odoratissima.

He will see from the turn of the hillside the Blair of Drummond waving with corn and shadowed with rich woods, where eighty years ago there was a black peat-moss ; and far off, on the horizon, Damyat and the Touch Fells; and at his side the little loch of Ruskie, in which he may see five Highland cattle, three tawny brown and two brindled, standing in the still water-themselves as still, all except their switching tails and winking ears - the perfect images of quiet enjoyment. By this time he will have come in sight of the Lake of Monteith, set in its woods, with its magical shadows and soft gleams. There is a loveliness, a gentleness and peace about it more like 'lone St. Mary's Lake,' or Derwent Water, than of any of its sister lochs. It is lovely rather than beautiful, and is a sort of gentle prelude, in the minor key, to the coming glories and intenser charms of Loch Ard and the true Highlands beyond. 


\section{Queen Mary's Child Garden.}

You are now at the Port, and have passed the secluded and cheerful manse, and the parish kirk with its graves, close to the lake, and the proud aisle of the Grahams of Gartmore washed by its waves. Across the road is the modest little inn, a Fisher's Tryst. On the unruffled water lie several islets, plump with rich foliage, brooding like great birds of calm. You somehow think of them as on, not in the lake, or like clouds lying in a nether sky-' like ships waiting for the wind.' You get a coble, and a yauld old Celt, its master, and are rowed across to Inch-mahome, the Isle of Rest. Here you find on landing huge Spanish chestnuts, one lying dead, others standing stark and peeled, like gigantic antlers, and others flourishing in their viridis senectus, and in a thicket of wood you see the remains of a monastery of great beauty, the design and workmanship, exquisite. You wander through the ruins, overgrown with ferns and Spanish filberts, and old fruit-trees, and at the corner of the old monkish garden you come upon one of the strangest and most touching sights you ever saw-an oval space of about eighteen feet by twelve, with the remains of a double row of boxwood all round, the plants of box being about fourteen feet high, and eight or nine inches in diameter, healthy, but plainly of great age.

What is this? it is called in the guide-books Queen Mary's Bower; but besides its being plainly not in 
the least a bower, what could the little Queen, then five years old, and 'fancy free,' do with a bower? It is plainly, as was, we believe, first suggested by our keen-sighted and diagnostic Professor of Clinical Surgery, ${ }^{1}$ the Child-Queen's Garden, with her little walk, and its rows of boxwood, left to themselves for three hundred years. Yes, without doubt, 'here is that first garden of her simpleness.' Fancy the little, lovely royal child, with her four Marys, her playfellows, her child maids of honour, with their little hands and feet, and their innocent and happy eyes, pattering about that garden all that time ago, laughing, and running, and gardening as only children do and can. As is well known, Mary was placed by her mother in this Isle of Rest before sailing from the Clyde for France. There is something 'that tirls the heartstrings a' to the life' in standing and looking on this unmistakable living relic of that strange and pathetic old time. Were we Mr. Tennyson, we would write an Idyll of that child Queen, in that garden of hers, eating her bread and honey-getting her teaching from the holy men, the monks of old, and running off in wild mirth to her garden and her flowers, all

1 The same seeing eye and understanding mind, when they were eighteen years of age, discovered and published the Solvent of Caoutchouc, for which a patent was taken out afterwards by the famous Mackintosh. If the young discoverer had secured the patent, he might have made a fortune as large as his present reputation-I don't suppose he much regrets that he didn't. 


\section{Queen Mary's Child-Garden.}

unconscious of the black, lowering thunder-cloud on Ben Lomond's shoulder.

' Oh, blessed vision! happy child!

Thou art so exquisitely wild :

I think of thee with many fears

Of what may be thy lot in future years.

I thought of times when Pain might be thy guest,

Lord of thy house and hospitality.

And Grief, uneasy lover! never rest

But when she sat within the touch of thee.

What hast thou to do with sorrow.

Or the injuries of to-morrow ?'

You have ample time to linger there amid

' The gleams, the shadows, and the peace profound,' and get your mind informed with quietness and beauty, and fed with thoughts of other years, and of her whose story, like Helen of Troy's, will continue to move the hearts of men as long as the grey hills stand round about that gentle lake, and are mirrored at evening in its depths. You may do and enjoy all this, and be in Princes Street by nine P.M. ; and we wish we were as sure of many things as of your saying, 'Yes, this is a pleasure that has pleased, and will please again; this was something expected which did not disappoint.'

There is another garden of Queen Mary's, which may still be seen, and which has been left to itself like that in the Isle of Rest. It is in the grounds at 
Chatsworth, and is moated, walled round, and raised about fifteen feet above the park. Here the Queen, when a prisoner under the charge of 'Old Bess of Hardwake,' was allowed to walk without any guard. How different the two! and how different she who took her pleasure in them!

Lines written on the steps of a small moated garden at Chatsworth, called

'Queen Mary's Bower.

'The moated bower is wild and drear, And sad the dark yew's shade;

The flowers which bloom in silence here, In silence also fade.

'The woodbine and the light wild rose Float o'er the broken wall ; And here the mournful nightshade blows, To note the garden's fall.

'Where once a princess wept her woes, The bird of night complains ; And sighing trees the tale disclose They learnt from Mary's strains. 


\section{O U R DOGS.}

'The misery of keeping a dog is his dying so soon; but to be sure, if he lived for fifty years, and then died, what would become of me?'-Sir WALTER SCOTT.

'There is in every animal's eye a dim image and sleam of humanity, a flash of strange light through which their life looks out and up to our great mystery of command over them, and claims the fellowship of the creature if not of the soul.'-RUSKIN.

'They say that Socrates swore by his dog.'-Montalg.ie. 
To Sir Walter and Lady Trevelvan's

glum and faithful

P E T E R,

with muck regunl. 


\section{OUR DOGS.}

I WAS bitten severely by a little dog when with my mother at Moffat Wells, being then three years of age, and I have remained 'bitten' ever since in the matter of dogs. I remember that little dog, and can at this moment not only recal my pain and terror-I have no doubt I was to blame-but also her face; and were I allowed to search among the shades in the cynic Elysian fields, I could pick her out still. All my life I have been familiar with these faithful creatures, making friends of them, and speaking to them; and the only time I ever addressed the public, about a year after being bitten, was at the farm of Kirklaw Hill, near Biggar, when the text, given out from an empty cart in which the ploughmen had placed me, was 'Jacob's dog,' and my entire sermon was as follows : 'Some say that Jacob had a black $\operatorname{dog}$ (the $o$ very long), and some say that Jacob had a white dog, but $I$ (imagine the presumption of four 
years !) say Jacob had a brown dog, and a brown dog it shall be.'

I had many intimacies from this time onwardsBawtie, of the inn; Keeper, the carrier's bull-terrier; Tiger, a huge tawny mastiff from Edinburgh, which I think must have been an uncle of Rab's; all the sheep dogs at Callands-Spring, Mavis, Yarrow, Swallow, Cheviot, etc. ; but it was not till I was at college, and my brother at the High School, that we possessed a dog.

\section{T O B Y}

Was the most utterly shabby, vulgar, mean-looking cur I ever beheld : in one word, a tyke. He had not one good feature except his teeth and eyes, and his bark, if that can be called a feature. He was not ugly enough to be interesting; his colour black and white, his shape leggy and clumsy; altogether what Sydney Smith would have called an extraordinarily ordinary dog: and, as I have said, not even greatly ugly, or, as the Aberdonians have it, bonnie wi illfauredness. My brother William found him the centre of attraction to a multitude of small blackguards who were drowning him slowly in Lochend Loch, doing their best to lengthen out the process, and secure the greatest amount of fun with the nearest approach to death. Even then Toby showed his great intellect by pretending to be dead, and thus 
gaining time and an inspiration. William bought him for twopence, and as he had it not, the boys accompanied him to Pilrig Street, when I happened to meet him, and giving the twopence to the biggest boy, had the satisfaction of seeing a general engagement of much severity, during which the twopence disappeared ; one penny going off with a very small and swift boy, and the other vanishing hopelessly into the grating of a drain.

Toby was for weeks in the house unbeknown to any one but ourselves two and the cook, and from my grandmother's love of tidiness and hatred of dogs and of dirt, I believe she would have expelled ' him whom we saved from drowning,' had not he, in his straightforward way, walked into my father's bedroom one night when he was bathing his feet, and introduced himself with a wag of his tail, intimating a general willingness to be happy. My father laughed most heartily, and at last Toby, having got his way to his bare feet, and having begun to lick his soles and between his toes with his small rough tongue, my father gave such an unwonted shout of laughter, that we-grandmother, sisters, and all of us-went in. Grandmother might argue with all her energy and skill, but as surely as the pressure of Tom Jones' infantile fist upon Mr. Allworthy's forefinger undid all the arguments of his sister, so did Toby's tongue and fun prove too many for grandmother's eloquence. I 
somehow think Toby must have been up to all this, for I think he had a peculiar love for my father ever after, and regarded grandmother from that hour with a careful and cool eye.

Toby, when full grown, was a strong coarse dog : coarse in shape, in countenance, in hair, and in manner. I used to think that, according to the Pythagorean doctrine, he must have been, or been going to be, a Gilmerton carter. He was of the bullterrier variety, coarsened through much mongrelism and a dubious and varied ancestry. His teeth were good, and he had a large skull, and a rich bark as of a dog three times his size, and a tail which I never saw equalled-indeed it was a tail per se; it was of immense girth and not short, equal throughout like a policeman's baton; the machinery for working it was of great power, and acted in a way, as far as I have been able to discover, quite original. We called it his ruler.

When he wished to get into the house, he first whined gently, then growled, then gave a sharp bark, and then came a resounding, mighty stroke which shook the house; this, after much study and watching, we found was done by his bringing the entire length of his solid tail flat upon the door, with a sudden and vigorous stroke; it was quite a tour de force or a coup de queue, and he was perfect in it at once, his first bang authori- 
tative, having been as masterly and telling as his last.

With all this inbred vulgar air, he was a dog of great moral excellence-affectionate, faithful, honest up to his light, with an odd humour as peculiar and as strong as his tail. My father, in his reserved way, was very fond of him, and there must have been very funny scenes with them, for we heard bursts of laughter issuing from his study when they two were by themselves: there was something in him that took that grave, beautiful, melancholy face. One can fancy him in the midst of his books, and sacred work and thoughts, pausing and looking at the secular Toby, who was looking out for a smile to begin his rough fun, and about to end by coursing and gurrin' round the room, upsetting my father's books, laid out on the floor for consultation, and himself nearly at times, as he stood watching him-and off his guard and shaking with laughter. Toby had always a great desire to accompany my father up to town; this my father's good taste and sense of dignity, besides his fear of losing his friend (a vain fear!), forbade, and as the decision of character of each was great and nearly equal, it was often a drawn game. Toby, ultimately, by making it his entire object, triumphed. He usually was nowhere to be seen on my father leaving; he however saw him, and lay in wait at the head of the street, and 
up Leith Walk he kept him in view from the opposite side like a detective, and then, when he knew it was hopeless to hound him home, he crossed unblushingly over, and joined company, excessively rejoiced of course.

One Sunday he had gone with him to church, and left him at the vestry door. The second psalm was given out, and my father was sitting back in the pulpit, when the door at its back, up which he came from the vestry, was seen to move, and gently open, then, after a long pause, a black shining snout pushed its way steadily into the congregation, and was followed by Toby's entire body. He looked somewhat abashed, but snuffing his friend, he advanced as if on thin ice, and not seeing him, put his fore-legs on the pulpit, and behold there he was, his own familiar chum. I watched all this, and anything more beautiful than his look of happiness, of comfort, of entire ease when he beheld his friendthe smoothing down of the anxious ears, the swing of gladness of that mighty tail,-I don't expect soon to see. My father quietly opened the door, and Toby was at his feet and invisible to all but himself; had he sent old George Peaston, the 'minister's man,' to put him out, Toby would probably have shown his teeth, and astonished George. He slunk home as soon as he could, and never repeated that exploit. 


\section{Toby.}

I never saw in any other dog the sudden transition from discretion, not to say abject cowardice, to blazing and permanent valour. From his earliest years he showed a general meanness of blood, inherited from many generations of starved, bekicked, and down-trodden forefathers and mothers, resulting in a condition of intense abjectness in all matters of personal fear; anybody, even a beggar, by a gowl and a threat of eye, could send him off howling by anticipation, with that mighty tail between his legs. But it was not always so to be, and I had the privilege of seeing courage, reasonable, absolute, and for life, spring up in Toby at once, as did Athené from the skull of Jove. It happened thus :-

Toby was in the way of hiding his culinary bones in the small gardens before his own and the neighbouring doors. Mr. Scrymgeour, two doors off, a bulky, choleric, red-haired, red-faced man-torvo vultu-was, by law of contrast, a great cultivator of flowers, and he had often scowled Toby into all but non-existence by a stamp of his foot and a glare of his eye. One day his gate being open, in walks Toby with a huge bone, and making a hole where Scrymgeour had two minutes before been planting some precious slip, the name of which on paper and on a stick Toby made very light of, substituted his bone, and was engaged covering it, or thinking he was covering it up with his shovelling nose (a very 
odd relic of paradise in the dog), when S. spied him through the inner glass-door, and was out upon him like the Assyrian, with a terrific gowl. I watched them. Instantly Toby made straight at him with a roar too, and an eye more torve than Scrymgeour's, who, retreating without reserve, fell prostrate, there is reason to believe, in his own lobby. Toby contented himself with proclaiming his victory at the door, and returning finished his bone-planting at his leisure; the enemy, who had scuttled behind the glass-door, glaring at him.

From this moment Toby was an altered dog. Pluck at first sight was lord of all; from that time dated his first tremendous deliverance of tail against the door, which we called 'come listen to my tail.' That very evening he paid a visit to Leo, next door's dog, a big, tyrannical bully and coward, which its master thought a Newfoundland, but whose pedigree we knew better; this brute continued the same system of chronic extermination which was interrupted at Lochend,- -having Toby down among his feet, and threatening him with instant death two or three times a day. To him Toby paid a visit that very evening, down into his den, and walked about, as much as to say 'Come on, Macduff!' but Macduff did not come on, and henceforward there was an armed neutrality, and they merely stiffened up and made their backs rigid, pretended each not to see 
the other, walking solemnly round, as is the manner of dogs. Toby worked his new-found faculty thoroughly, but with discretion. He killed cats, astonished beggars, kept his own in his own garden against all comers, and came off victorious in several well-fought battles; but he was not quarrelsome or foolhardy. It was very odd how his carriage changed, holding his head up, and how much pleasanter he was at home. To my father, next to William, who was his Humane Society man, he remained stanch. He had a great dislike to all things abnormal, as the phrase now is. A young lady of his acquaintance was calling one day, and, relating some distressing events, she became hysterical. Of this Toby did not approve, and sallying from under my father's chair, attacked his friend, barking fiercely, and cut short the hysterics better than any sal volatile or valerian. He then made abject apologies to the patient, and slunk back to his chair.

And what of his end? for the misery of dogs is that they die so soon, or, as Sir Walter says, it is well they do ; for if they lived as long as a Christian, and we liked them in proportion, and they then died, he said that was a thing he could not stand.

His exit was lamentable, and had a strange poetis or tragic relation to his entrance. My father was cut of town; I was away in England. Whether it was that the absence of my father had relaxed his power 
of moral restraint, or whether through neglect of the servant he had been desperately hungry, or most likely both being true, Toby was discovered with the remains of a cold leg of mutton, on which he had made an ample meal ${ }^{1}$ this he was in vain endeavouring to plant as of old, in the hope of its remaining undiscovered till to-morrow's hunger returned, the whole shank-bone sticking up unmistakably. This was seen by our excellent and Rhadamanthine grandmother, who pronounced sentence on the instant; and next day, as William was leaving for the High School, did he in the sour morning, through an easterly haur, behold him 'whom he saved from drowning,' and whom, with better results than in the case of Launce and Crab, he had taught, as if one should say 'thus would I teach a dog,'-dangling by his own chain from his own lamp-post, one of his hind feet just touching the pavement, and his body preternaturally elongated.

William found him dead and warm, and falling in with the milk-boy at the head of the street, questioned him, and discovered that he was the executioner, and had got twopence, he-Toby's every morning's crony, who met him and accompanied him up the street,

${ }^{1}$ Toby was in the state of the shepherd boy whom George Webster met in Glenshee, and asked, 'My man, were you ever fou' ?' 'Ay, aince'-speaking slowly, as if remembering- 'Ay, aince.' 'What on ?' 'Cauld mutton!' 


\section{Wylie.}

and licked the outside of his can-had, with an eye to speed and convenience, and a want of taste, not to say principle and affection, horrible still to think of, suspended Toby's animation beyond all hope. William instantly fell upon him, upsetting his milk and cream, and gave him a thorough licking, to his own intense relief; and, being late, he got from Pyper, who was a martinet, the customary palmies, which he bore with something approaching to pleasure. So died Toby; my father said little, but he missed and mourned his friend.

There is reason to believe that by one of those curious intertwistings of existence, the milk-boy was that one of the drowning party who got the penny of the twopence.

\section{W Y L I E.}

Our next friend was an exquisite shepherd's dog; fleet, thin-flanked, dainty, and handsome as a small greyhound, with all the grace of silky waving black and $\tan$ hair. We got her thus. Being then young and keen botanists, and full of the knowledge and love of Tweedside, having been on every hill-top from Muckle Mendic to Hundleshope and the Lee Pen, and having fished every water from Tarth to the Leithen, we discovered early in spring that young Stewart, author of an excellent book on natural history, a young man of great promise and early death, 
had found the Buxbaumia aphylla, a beautiful and odd-looking moss, west of Newbie heights, in the very month we were that moment in. We resolved to start next day. We walked to Peebles, and then up Haystoun Glen to the cottage of Adam Cairns, the aged shepherd of the Newbie hirsel, of whom we knew, and who knew of us from his daughter, Nancy Cairns, a servant with Uncle Aitken of Callands. We found our way up the burn with difficulty, as the evening was getting dark; and on getting near the cottage heard them at worship. We got in, and made ourselves known, and got a famous tea, and such cream and oat cake!-old Adam looking on us as ' clean dementit' to come out for 'a bit moss,' which, however, he knew, and with some pride said he would take us in the morning to the place. As we were going into a box bed for the night, two young men came in, and said they were 'gaun to burn the water.' Off we set. It was a clear, dark, starlight frosty night. They had their leisters and tar torches, and it was something worth seeing-the wild flame, the young fellows striking the fish coming to the light-how splendid they looked with the light on their scales, coming out of the darkness - the stumblings and quenchings suddenly of the lights, as the torch-bearer fell into a deep pool. We got home past midnight, and slept as we seldom sleep now. In the morning Adam, who had been long risen, and up the Hope 
with his dog, when he found we had wakened, told us there was four inches of snow, and we soon saw it was too true. So we had to go home without our cryptogamic prize.

It turned out that Adam, who was an old man and frail, and had made some money, was going at Whitsunday to leave, and live with his son in Glasgow. We had been admiring the beauty and gentleness and perfect shape of Wylie, the finest collie I ever saw, and said, 'What are you going to do with Wylie?' ''Deed,' says he, 'I hardly ken. I canna think o' selling her, though she's worth four pound, and she 'll no like the toun.' I said, 'Would you let me have her?' and Adam, looking at her fondly, - she came up instantly to him, and made of himsaid, 'Ay, I wull, if ye'll be gude to her ;' and it was settled that when Adam left for Glasgow she should be sent into Albany Street by the carrier.

She came, and was at once taken to all our hearts - even grandmother liked her; and though she was often pensive, as if thinking of her master and her work on the hills, she made herself at home, and behaved in all respects like a lady. When out with me, if she saw sheep in the streets or road, she got quite excited, and helped the work, and was curiously useful, the being so making her wonderfully happy. And so her little life went on, never doing wrong, always blithe and kind and beautifui. 
But some months after she came, there was a mystery about her: every Tuesday evening she disappeared; we tried to watch her, but in vain, she was always off by nine P.M., and was away all night, coming back next day wearied and all over mud, as if she had travelled far. She slept all next day. This went on for some months, and we could make nothing of it. Poor dear creature, she looked at us wistfully when she came in, as if she would have told us if she could, and was especially fond, though tired.

Well, one day I was walking across the Grassmarket, with Wylie at my heels, when two shepherds started, and looking at her, one said, 'That's her; that's the wonderfu' wee bitch that naebody kens.' I asked him what he meant, and he told me that for months past she had made her appearance by the first daylight at the 'buchts' or sheep-pens in the cattle-market, and worked incessantly, and to excellent purpose, in helping the shepherds to get their sheep and lambs in. The man said with a sort of transport, 'She's a perfect meeracle; flees about like a speerit, and never gangs wrang; wears but never grups, and beats a' oor dowgs. She's a perfect meeracle, and as soople as a maukin.' Then he related how they all knew her, and said, 'There's that wee fell yin; we'll get them in noo.' 'They tried to coax her to stop and be caught, but no, she 


\section{Wylie.}

was gentle, but off; and for many a day 'that wee fell yin' was spoken of by these rough fellows. She continued this amateur work till she died, which she did in peace.

It is very touching the regard the south-country shepherds have to their dogs. Professor Syme one day, many years ago, when living in Forres Street, was looking out of his window, and he saw a young shepherd striding down North Charlotte Street, as if making for his house : it was midsummer. The man had his dog with him, and Mr. Syme noticed that he followed the dog, and not it him, though he contrived to steer for the house. He came, and was ushered into his room; he wished advice about some ailment, and Mr. Syme saw that he had a bit of twine round the dog's.neck, which he let drop out of his hand when he entered the room. He asked him the meaning of this, and he explained that the magistrates had issued a mad-dog proclamation, commanding all dogs to be muzzled or led on pain of death. 'And why do you go about as I saw you did before you' came in to me?' 'Oh,' said he, looking awkward, 'I didna want Birkie to ken he was tied.' Where will you find truer courtesy and finer feeling? He didn't want to hurt Birkie's feelings.

Mr. Carruthers of Inverness told me a new story of these wise sheep-dogs. A butcher from Inverness 
had purchased some sheep at Dingwall, and giving them in charge to his dog, left the road. The dog drove them on, till coming to a toll, the toll-wife stood before the drove, demanding her dues. The dog looked at her, and, jumping on her back, crossed his forelegs over her arms. The sheep passed through, and the dog took his place behind them, and went on his way.

\section{RAB.}

Of Rab I have little to say, indeed have little right to speak of him as one of 'our dogs ;' but nobody will be sorry to hear anything of that noble fellow. Ailie, the day or two after the operation, when she was well and cheery, spoke about him, and said she would tell me fine stories when I came out, as I promised to do, to see her at Howgate. I asked her how James came to get him. She told me that one day she saw James coming down from Leadburn with the cart; he had been away west, getting eggs and butter, cheese and hens, for Edinburgh. She saw he was in some trouble, and on looking, there was what she thought a young calf being dragged, or, as she called it, 'haurled,' at the back of the cart. James was in front, and when he came up, very warm and very angry, she saw that there was a huge young dog tied to the cart, struggling and pull- 


\section{Rab.}

ing back with all his might, and as she said, 'lookin' fearsome.' James, who was out of breath and temper, being past his time, explained to Ailie, that this ' muckle brute o' a whalp' had been worrying sheep, and terrifying everybody up at Sir George Montgomery's at Macbie Hill, and that Sir George had ordered him to be hanged, which, however, was sooner said than done, as 'the thief' showed his intentions of dying hard. James came up just as Sir George had sent for his gun; and as the dog had more than once shown a liking for him, he said he 'wad gie him a chance ;' and so he tied him to his cart. Young Rab, fearing some mischief, had been entering a series of protests all the way, and nearly strangling himself to spite James and Jess, besides giving Jess more than usual to do. 'I wish I had let Sir George pit that charge into him, the thrawn brute,' said James. But Ailie had seen that in his fore-leg there was a splinter of wood, which he had likely got when objecting to be hanged, and that he was miserably lame. So she got James to leave him with her, and go straight into Edinburgh. She gave him water, and by her woman's wit got his lane paw under a door, so that he couldn't suddenly get at her, then with a quick firm hand she plucked out the splinter, and put in an ample meal. She went in some time after, taking no notice of him, and he came limping up, and laid his great jaws in her lap : 
from that moment they were 'chief,' as she said, James finding him mansuete and civil when he returned.

She said it was Rab's habit to make his appearance exactly half-an-hour before his master, trotting in full of importance, as if to say, 'He's all right, he'll be here.' One morning James came without him. He had left Edinburgh very early, and in coming near Auchindinny, at a lonely part of the road, a man sprang out on him, and demanded his money. James, who was a cool hand, said, 'Weel-a-weel, let me get it,' and stepping back, he said to Rab, 'Speak till him, my man.' In an instant Rab was standing over him, threatening strangulation if he stirred. James pushed on, leaving Rab in charge; he looked back, and saw that every attempt to rise was summarily put down. As he was telling Ailie the story, up came Rab with that great swing of his. It turned out that the robber was a Howgate lad, the worthless son of a neighbour, and Rab knowing him had let him cheaply off; the only thing, which was seen by a man from a field, was, that before letting him rise, he quenched (pro tempore) the fire of the eyes of the ruffian, by a familiar Gulliverian application of Hydraulics, which I need not further particularize. James, who did not know the way to tell an untruth, or embellish anything, told me this as what he called ' a fact positeevely.' 


\section{Wasp.}

\section{WASP}

Was a dark brindled bull-terrier, as pure in blood as Cruiser or Wild Dayrell. She was brought by my brother from Otley, in the West Riding. She was very handsome, fierce, and gentle, with a small, compact, finely-shaped head, and a pair of wonderful eyes -as full of fire and of softness as Grisi's; indeed she had to my eye a curious look of that wonderful genius - at once wild and fond. It was a fine sight to see her on the prowl across Bowden Moor, now cantering with her nose down, now gathered up on the top of a dyke, and with erect ears, looking across the wild like a moss-trooper out on business, keen and fell. She could do everything it became a dog to do, from killing an otter or a pole-cat, to watching and playing with a baby, and was as docile to her master as she was surly to all else. She was not quarrelsome, but 'being in,' she would have pleased Polonius as much, as in being 'ware of entrance.' She was never beaten, and she killed on the spot several of the country bullies who came out upon her when following her master in his rounds. She generally sent them off howling with one snap, but if this was not enough, she made an end of it.

But it was as a mother that she shone; and to see the ginsy, Hagar-like creature nursing her occasional 
Ishmael - playing with him, and fondling him all over, teaching his teeth to war, and with her eye and the curl of her lip daring any one but her master to touch him, was like seeing Grisi watching her darling 'Gennaro,' who so little knew why and how much she loved him.

Once when she had three pups, one of them died. For two days and nights she gave herself up to trying to bring it to life-licking it, and turning it over and over, growling over it, and all but worrying it to awake it. She paid no attention to the living two, gave them no milk, flung them away with her teeth, and would have killed them, had they been allowed to remain with her. She was as one possessed, and. neither ate, nor drank, nor slept, was heavy and miserable with her milk, and in such a state of excitement that no one could remove the dead pup.

Early on the third day she was seen to take the pup in her mouth, and start across the fields towards the Tweed, striding like a race-horse-she plunged in, holding up her burden, and at the middle of the stream dropped it, and swam swiftly ashore: then she stood and watched the little dark lump floating away, bobbing up and down with the current, and losing it at last far down, she made her way home, sought out the living two, devoured them with her love, carried them one by one to her lair, and gave herself up wholly to nurse them : you can fancy her 
mental and bodily happiness and relief when they were pulling away-and theirs.

On one occasion my brother had lent her to a woman who lived in a lonely house, and whose husband was away for a time. She was a capital watch. One day an Italian with his organ camefirst begging, then demanding money-showing that he knew she was alone, and that he meant to help himself, if she didn't. She threatened to 'lowse the dowg;' but as this was Greek to him, he pushed on. She had just time to set Wasp at him. It was very short work. She had him by the throat, pulled him and his organ down with a heavy crash, the organ giving a ludicrous sort of cry of musical pain. Wasp, thinking this was from some creature within, possibly a whittret, left the ruffian, and set to work tooth and nail on the box. Its master slunk off, and with mingled fury and thankfulness, watched her disembowelling his only means of an honest living. The woman good-naturedly took her off, and signed to the miscreant to make himself and his remains scarce. This he did with a scowl; and was found in the evening in the village, telling a series of lies to the watchmaker, and bribing him with a shilling to mend his pipes - 'his kist o' whussels.' 


\section{J OC K}

Was insane from his birth; at first an amabilis insania, but ending in mischief and sudden death. $\mathrm{He}$ was an English terrier, fawn-coloured; his mother's name VAMP (Vampire), and his father's Demon. He was more properly daft than mad; his courage, muscularity, and prodigious animal spirits making him insufferable, and never allowing one sane feature of himself any chance. No sooner was the street-door open, than he was throttling the first dog passing, bringing upon himself and me endless grief. Cats he tossed up into the air, and crushed their spines as they fell. Old ladies he upset by jumping over their heads; old gentlemen by running between their legs. At home, he would think nothing of leaping through the tea-things, upsetting the urn, cream, etc., and at dinner the same sort of thing. I believe if I could have found time to thrash him sufficiently, and let him be a year older, we might have kept him ; but having upset an Earl when the streets were muddy, I had to part with him. He was sent to a clergyman in the island of Westray, one of the Orkneys ; and though he had a wretched voyage, and was as sick as any dog, he signalized the first moment of his arrival at the manse, by strangling an ancient monkey, or 


\section{Duchie.}

'puggy,' the pet of the minister, - who was a bachelor, - and the wonder of the island. Jock henceforward took to evil courses, extracting the kidneys of the best young rams, driving whole hirsels down steep places into the sea, till at last all the guns of Westray were pointed at him, as he stood at bay under a huge rock on the shore, and blew him into space. I always regret his end, and blame myself for sparing the rod. Of

\section{U C H I E}

I have already spoken; her oddities were endless. We had and still have a dear friend,-_ Cousin Susan' she is called by many who are not her cousins-a perfect lady, and, though hopelessly deaf, as gentle and contented as ever Griselda with the full use of her ears ; quite as great a pet, in a word, of us all as Duchie was of ours. One day we found her mourning the death of a cat, a great playfellow of the Sputchard's, and her small Grace was with us when we were condoling with her, and we saw that she looked very wistfully at Duchie. I wrote on the slate, 'Would you like her?' and she through her tears said, 'You know that would never do.' But it did do. We left Duchie that very night, and though she paid us frequent visits, she was Cousin Susan's for life. I fear indulgence dulled her moral sense. She was 
an immense happiness to her mistress, whose silent and lonely days she made glad with her oddity and mirth. And yet the small creature, old, toothless, and blind, domineered over her gentle friendthreatening her sometimes if she presumed to remove the small Fury from the inside of her own bed, into which it pleased her to creep. Indeed, I believe it is too true, though it was inferred only, that her mistress and friend spent a great part of a winter night in trying to coax her dear little ruffian out of the centre of the bed. One day the cook asked what she would have for dinner: 'I would like a muttonchop, but then, you know, Duchie likes minced veal better!' The faithful and happy little creature died at a great age, of natural decay.

But time would fail me, and I fear patience would fail you, my reader, were $I$ to tell you of CRAB, of John Pym, of Puck, and of the rest. Crab, the Mugger's dog, grave, with deep-set, melancholy eyes, as of a nobleman (say the Master of Ravenswood) in disguise, large visaged, shaggy, indomitable, come of the pure Piper Allan's breed. This Piper Allan, you must know, lived some two hundred years ago in Cocquet Water, piping like Homer, from place to place, and famous not less for his dog than for his music, his news and his songs. The Earl of Northumberland, of his day, offered the piper a small farm for his dog, but after deliberating for a day, 
Allan said, 'Na, na, ma Lord, keep yir ferum; what wud a piper do wi' a ferum?'1 From this dog descended Davidson (the original Dandie Dinmont) of Hyndlee's breed, and Crab could count his kin up to him. He had a great look of the Right Honourable Edward Ellice, and had much of his energy and

1 I have to thank cordially the writer of the following letters. They are from the pen of Mr. Robert White, Newcastle-onTyne, author of the History of the Battle of Otterburn, and one of the last of the noble band of literary and local antiquarians of which 'Muncaster' has so long been the seat, up to all traditional lore and story of the stout-hearted Border.

'In the second series of your Hore Subseciva, p. 162, you allude to the dog Crab being come of the pure "Piper Allan's breed," and say that the said "Piper Allan lived some two hundred years ago in Cocquet (Coquet) Water."

'In Northumberland and over the Borders, James Allan is generally known as Piper Allan. He was born about 1733, and after leading a strange life, towards his seventieth year he stole a horse at Gateshead in the county of Durham, and took it to Lilliesleaf in Roxburghshire, where he was apprehended, and sent to Durham jail. He was found guilty, and received sentence of death, but was reprieved, and afterwards had his punishment mitigated to perpetual imprisonment. After being confined for nearly seven years, his health failed, and he was removed to the House of Correction, where he lived about five months, and died at Durham, November 13th, I8Io, aged about 77 years.

'Some time ago in Willis's Current Notes, which are now discontinued, an original letter of Sir Walter Scott was printed, in which is the following paragraph :-

" "I should be glad to see a copy of the Alnwick work upon Allan, whom I have often seen and heard, particularly at the Kelso Races. He was an admirable piper, yet a desperate reprobate. The last time I saw him he was in absolute beggary, 
wecht; had there been a dog House of Commons, Crab would have spoken as seldom, and been as great a power in the house, as the formidable and faithful time-out-of-mind member for Coventry.

John Pym was a smaller dog than Crab, of more fashionable blood, being a son of Mr. Somner's

and had behaved himself so ill at my uncle's (Thomas Scott of Monklaw) house, that the old gentleman, himself a most admirable piper, would not on any account give him quarters, though I interceded earnestly for him, 'the knave,' as Davie tells Justice Shallow, 'being my very good friend.' He was then quite like a pauper, with his wife, and an ass, in the true gipsy fashion. When I first saw him at Kelso Races, he wore the Northumberland livery, a blue coat, with a silver crescent on his arm." (Allan was piper to Her Grace the Duchess of Northumberland.)

' The father of Jamie Allan was named. Willie, and he also was a good piper, besides being an excellent fisher and a keen otter-hunter. He had two favourite dogs for the latter sport, - Charley and Phœbe, - and such was the wisdom of the former that he used to say, "If Charley could speak he would sell the otter skin." Probably Crab may have been of this kind.

"James Davidson of Hindlee was a great fox-hunter, and his breed of terriers-the pepper-and-mustard class-were the best over all the country. I have seen the genuine breed long ago at Ned Dunn's of the Whitelee at the head of Redesdale. Among common dogs they were something like the Black Dwarf among men, long-bodied animals with strong short legs, wiry haired, and at the first look not unlike a low four-footed stool, such as I have seen in houses in the south of Scotland forty years ago. They were sent in to the fox when he was earthed, and fought him there. They seemed at first when out of doors to be shy, timid things, and would have slunk away from a fierce collie dog, but if he seized one of them, and the blood of the little creature got up, it just took a hold of him in a bit- 


\section{Fohn Pym.}

famous SHEM, whose father and brother are said to have been found dead in a drain into which the hounds had run a fox. It had three entrances; the father was put in at one hole, the son at another, and speedily the fox bolted out at the third, but no appearance of the little terriers, and, on digging,

ing place, and held on, never quitting till he found to his cost he had caught a tartar.'

'I am now convinced, from what I have gleaned of the life of James Allan, and a notice in Mackenzie's History of Northumberland, that your Piper Allan was William, the father of James. He was born at Bellingham in I704. He was nearly six feet high, of a ruddy complexion, and had much shrewdness, wit, and independence of mind. In early life he became a good player on the bagpipes. He mended pots and pans, made spoons, baskets, and besoms, and was a keen and excellent fisher. In the Valley of Coquet he married a gipsy girl, named Betty, who bore him six children, and James was the youngest save one; but she died in the prime of life. He was married a second time to an unfortunate daughter of a Presbyterian minister.

'Among his other pursuits, he excelled especially in the hunting of otters, and kept eight or ten dogs for that particular sport. Please turn to my previous letter, and in the passage, "if Charley could speak," etc., dele Charley and insert Peachem. This dog was Will's chief favourite, and such confidence had he in the animal, that when hunting he would at times observe, " When my Peachem gi'es mouth, I durst always sell the otter's skin." Charley was also an excellent dog. Lord Ravensworth once employed Willie to kill the otters that infested his pond at Eslington Hall, which he soon accomplished ; and on going away, the steward, Mr. Bell, offered, in his Lordship's name, to buy Charley at the Piper's own price. Will turned round very haughtily, and exclaimed, "By the zouns, his hale estate canna buy Charley!" 
they were found dead, locked in each other's jaws ; they had met, and it being dark, and there being no time for explanations, they liad throttled each other. John was made of the same sort of stuff, and was as combative and victorious as his great namesake, and not unlike him in some of his not so creditable

"He was a capital piper, and composed two popular tunes, "We'll a' to the Coquet and Woo," and "Salmon Tails up the Water." These I never heard, and probably they may be lost. When his end drew near, he was something like Rob Roy in his neglect of religious impressions. When reminded that he was dying, he exclaimed, "By Jing, I'll get foul play, then, to dee before my billie, wha's ten years aulder!" When still closer pressed to ponder on his condition, he said, "Gi'e me my pipes, and I'll play ye "Dorrington Lads' yet." Thus he exhausted his last breath in playing his favourite strain. He died I8th February I779, aged seventy-five years, and was buried in Rothbury churchyard. His son James was born at Kepple, in Coquetdale, March 1734

"The following verses on old Will are in the "Lay of the Reedwater Minstrel :"-

"A stalwart Tinkler wight was he, And weel could mend a pot or pan ; And deftly $W$ ull could thraw a flee, An' neatly weave the willow-wan'.

“ An' sweetly wild were Allan's strains, An' mony a jig an' reel he blew;

Wi' merry lilts he charm'd the swains, Wi' barbèd spear the otter slew.

" Nae mair he'll scan, wi' anxious eye, The sandy shores of winding Reed; Nae mair he'll tempt the finny fry,The king o' Tinklers, Allan's dead.

" Nae mair at Mell or Merry Night

The cheering bagpipes $W$ ull shall blaw : 


\section{Fohn Pym.}

qualities. He must, I think, have been related to a certain dog to whom 'life was full o' sairiousness,' but in John's case the same cause produced an opposite effect. John was gay and light-hearted, even when there was not ' enuff o' fechtin,' which, however, seldom happened, there being a market every week

Nae mair the village throng delight,

Grim death has laid the minstrel law.

" Now trouts, exulting, cut the wave;

Triumphant see the otter glide ;

Their deadly foe lies in his grave,

Charley and Phabe by his side." ,

I add another bit from Mr. White, too characteristic of that mixture of kindness and cruelty, of tenderness and pluck,-Dandie Dinmont, - and of the exercise, called one-sidedly 'sport.' It ends happily, which is more than the big store-farmer wished :-

'The mother of the far-famed Peppers and Mustards was a dark-coloured, rough-haired bitch of the name of Tar. Davidson wanted a cat from some of the cottages at a distance from Hindlie, that he might have the young dogs tried upon it. One of his shepherds chanced to call at Andrew Telfer's house (the grandfather, I believe, of my late friend), where he saw baudrons sitting on the end of a dresser near the door ; and the house being low and dark, he swept her into his plaid-neuk on going out, and carried her home. Next morning she was introduced to a covered drain, which ran across the road, the said drain being closed up at one end, whereby she was compelled to give battle to her foes. A young terrier was the first to oppose her, and paid for its rashness by retreating from the drain with the skin almost torn from its nose. Another of the same age met with the same punishment, and Davidson, considerably irritated, brought forward Tar, the old lady, who, by her age and experience, he considered, would be more than a match for the cat. There was sore fighting for a time, till again Puss was victo- 
in Melrose, and John appearing most punctually at the cross to challenge all comers, and being short legged, he inveigled every dog into an engagement by first attacking him, and then falling down on his back, in which posture he latterly fought and won all his battles. What can I say of $\mathrm{PuCK}^{1}$ - the thoroughbred-

rious, and Tar withdrew from the conflict in such a condition that her master exclaimed, "Confoond the cat, she's tumblt an e'e oot o' the bitch!" which indeed was the case. "Tak awa the stanes frae the tap o' the cundy," said Davidson, "and we'll ha'e her worried at ance." The stones were removed, and out leapt the cat in the middle of her enemies. Fortunately for her, however, it happened that a stone wall was continued up the side of the road, which she instantly mounted, and, running along the top thereof, with the dogs in full cry after her, she speedily reached a plantation, and eluded all pursuit. No trace of her could be discovered; and the next time the shepherd called at Andrew Telfer's house, my lady was seated on the dresser, as demure as if nothing in her whole life had ever disturbed her tranquillity.'

${ }^{1}$ In The Dog, by Stonehenge, an excellent book, there is a woodcut of Puck, and 'Dr. Wm. Brown's celebrated dog John Pym' is mentioned. Their pedigrees are given-here is Puck's, which shows his 'strain' is of the pure azure blood- 'Got by John Pym, out of Tib; bred by Purves of Leaderfoot ; sire, Old Dandie, the famous dog of old John Stoddart of Selkirkdam Whin.' How Homeric all this sounds! I cannot help quoting what follows--'Sometimes a Dandie pup of a good strain may appear not to be game at an early age; but he should not be parted with on this account, because many of them do not show their courage till nearly two years old, and then nothing can beat them ; this apparent softness arising, as I suspect, from kindness of heart'-a suspicion, my dear 'Stonehenge,' which is true, and shows your own 'kindness of heart,' as well as sense. 
the simple-hearted-the purloiner of eggs warm from the hen-the flutterer of all manner of Volsciansthe bandy-legged, dear, old, dilapidated buffer? I got him from my brother, and only parted with him because William's stock was gone. $\mathrm{He}$ had to the end of life a simplicity which was quite touching. One summer day-a dog-day-when all dogs found straying were hauled away to the police-office, and killed off in twenties with strychnine, I met Puck trotting along Princes Street with a policeman, a rope round his neck, he looking up in the fatal, official, but kindly countenance in the most artless and cheerful manner, wagging his tail and trotting along. In ten minutes he would have been in the next world; for I am one of those who believe dogs have a next world, and why not? Puck ended his days as the best dog in Roxburghshire. Placide quiescas !

\section{I C K}

Still lives, and long may he live! As he was never born, possibly he may never die; be it so, he will miss us when we are gone. I could say much of him, but agree with the lively and admirable Dr. Jortin, when, in his dedication of his Remarks on Ecclesiastical History to the then (1752) Archbishop of Canterbury, he excuses himself for not following the modern custom of praising his Patron, by remind- 
ing his Grace 'that it was a custom amongst the ancients, not to sacrifice to heroes till after sunset.' I defer my sacrifice till Dick's sun is set.

I think every family should have a dog; it is like having a perpetual baby ; it is the plaything and crony of the whole house. It keeps them all young. All unite upon Dick. And then he tells no tales, betrays no secrets, never sulks, asks no troublesome questions, never gets into debt, never coming down late for breakfast, or coming in by his Chubb too early to bed-is always ready for a bit of fun, lies in wait for it, and you may, if choleric, to your relief, kick him instead of some one else, who would not take it so meekly, and, moreover, would certainly not, as he does, ask your pardon for being kicked.

Never put a collar on your dog-it only gets him stolen; give him only one meal a day, and let that, as Dame Dorothy, Sir Thomas Browne's wife, would say, be 'rayther under.' Wash him once a week, and always wash the soap out; and let him be carefully combed and brushed twice a week.

By the bye, I was wrong in saying that it was Burns who said Man is the god of the Dog-he got it from Bacon's Essay on Atheism, or perhaps more truly-Bacon had it first. 


\section{NOTES ON ART.}

'The use of this feigned history' (the Ideal Arts of Poesy, Painting, Music, Eoc.) 'hath been to give some sHadow of SATISFACTION TO THE MIND OF MAN IN THESE POINTS WHEREIN THE NATURE OF THINGS DOTH DENY IT, the world being in proportion inferior to the soul; by reason whereof, there is, agreeable to the spirit of man, A MORE AMPLE GREATNESS, A MORE EXACT GOODNESS, AND A MORE ABSOLUTE VARIETY, than can be found in the nature of things. So it appeareth that Pocsy' (and the others) 'serveth and conferreth to magnanimity, morality, and to delectation. And therefore it was ever thought to have some participation of divineness because IT DOTH RAISE AND ERECT THE MIND, BY SUBMITTING THE SHEWS OF THINGS TO THE DESIRES OF THE MIND ; whereas reason' (science, philosophy) 'doth buckle and bow the mind to the nature of things.'-OF THE PROFICIENCE AND ADVANCEMENT OF LEARNiNG.

' To look on noble forms

Makes noble through the sensuous organism

That which is higher.'-THE PRINCESS.

The statue' of the Duke Lorenzo by Michael Angelo 'is larger than life, but not so large as to shock belief. It is the most real and unreal thing that ever came from the chisel.' - Note in Rogers's 'ItTAly.' These two words, 'real and unreal,' comprehend the philosophy of art; which proposes to itself the idealizing of the real, and the realizing of the ideal. 



\section{NOTES ON ART.}

ONE evening in the spring of 1846 , as my wife and I were sitting at tea, Parvula in bed, and the Sputchard reposing, as was her wont, with her rugged little brown forepaws over the edge of the fender, her eyes shut, toasting, and all but roasting herself at the fire, - a note was brought in, which, from its fat, soft look, by a hopeful and not unskilled palpitation I diagnosed as that form of lucre which in Scotland may well be called filthy. I gave it across to Madam, who, opening it, discovered four five-pound notes, and a letter addressed to me. She gave it me. It was from Hugh Miller, editor of the Witness newspaper, asking me to give him a notice of the Exhibition of the Scottish Academy then open, in words I now forget, but which were those of a thorough gentleman, and enclosing the aforesaid fee. I can still remember, or indeed feel the kind of shiver, half of fear. and pleasure, on encountering this temptation; but I soon said, 'You 
know I can't take this; I can't write; I never wrote a word for the press.' She, with 'wifelike government,' kept the money, and heartened me to write, and write I did, but with awful sufferings and difficulty, and much destruction of sleep. I think the only person who suffered still more must have been the compositor. Had this packet not come in, and come in when it did, and had the Sine Quâ Non not been retentive and peremptory, there are many chances to one I might never have plagued any printer with my bad hand and my endless corrections, and my general incoherency as to proofs, teste Jacobo Gray.

I tell this small story, partly for my own pleasure, and as a tribute to that remarkable man, who stands alongside of Burns and Scott, Chalmers and Carlyle, the foremost. Scotsmen of their time-a rough, almost rugged nature, shaggy with strength, clad with zeal as with a cloak, in some things sensitive and shamefaced as a girl; moody and self-involved, but never selfish; full of courage, and of keen insight into nature and men, and the principles of both, but simple as a child in the ways of the world; selftaught and self-directed, argumentative and scientific, as few men of culture have ever been, and yet with more imagination than either logic or knowledge; to the last as shy and blate as when working in the quarries at Cromarty. In his life a noble example 
of what our breed can produce, of what energy, honesty, intensity, and genius can achieve; and in his death a terrible example of that revenge which the body takes upon the soul when brought to bay by its inexorable taskmaster. I need say no more. His story is more tragic than any tragedy. Would to God it may warn those who come after to be wise in time, to take the same-I ask no more-care of their body, which is their servant, their beast of burden, as they would of their horse.

Few men are endowed with such a brain as Hugh Miller-huge, active, concentrated, keen to fierceness ; and therefore few men need fear, even if they misuse and overtask theirs as he did, that it will turn, as it did with him, and rend its master. But as assuredly as there is a certain weight which a bar of iron will bear and no more, so is there a certain weight of work which the organ by which we act, by which we think, and feel, and will-cannot sustain, blazing up into brief and ruinous madness, or sinking into idiocy. At the time he wrote to me, Mr. Miller and I were strangers, and I don't think I ever spoke to him; but his manner of doing the above act made me feel, that in that formidable and unkempt nature there lay the delicacy, the generosity, the noble trustfulness of a gentleman born- not made. But my chief reason for what I have written is to make a sort of cxcuse for reprinting portions of 
these papers, and of some others which have appeared from time to time in the Scotsman. I reprint them mainly, it must be confessed, to fill up the volume, having failed to do what I had purposed in the way of new matter, from want of leisure; and I suspect also from want of material. I therefore must be understood as making much the same sort of apology as a housewife makes for a cold dinner, - a want of time, and, it may be, a want of beef.

Most men have, and almost every man should have, a hobby: it is exercise in a mild way, and does not take him away from home; it diverts him; and by having a double line of rails, he can manage to keep the permanent way in good condition. A man who has only one object in life, only one line of rails, who exercises only one set of faculties, and these only in one way, will wear himself out much sooner than a man who shunts himself every now and then, and who has trains coming as well as going; who takes in as well as gives out.

My hobby has always been pictures, and all we call Art. I have fortunately never been a practitioner, though I think I could have made a tolerable hand; but unless a man is a thoroughly good artist, he injures his enjoyment, generally speaking, of the art of others. I am convinced, however, that to enjoy art thoroughly, every man must have in him the possibility of doing it as well as liking it. He 
must feel it in his fingers, as well as in his head and at his eyes; and it must find its way from all the three to his heart, and be emotive.

Much has been said of the power of Art to refine men, to soften their manners, and make them less of wild beasts. Some have thought it omnipotent for this; others have given it as a sign of the decline and fall of the nobler part of us. Neither is and both are true. Art does, as our Laureate says, make nobler in us what is higher than the senses through which it passes; but it can only make nobler what is already noble; it cannot regenerate, neither can it of itself debase and emasculate and bedevil mankind; but it is a symptom, and a fatal one, when Art ministers to a nation's vice, and glorifies its naughtiness - as in old Rome, as in Oude-as also too much in places nearer in time and place than the one and the other. The truth is, Art, unless quickened from above and from within, has in it nothing beyond itself, which is visible beauty - the ministration to the lust, the desire of the eye. But apart from direct spiritual worship, and selfdedication to the Supreme, I do not know any form of ideal thought and feeling which may be made more truly to subserve, not only magnanimity, but the purest devotion and godly fear; by fear, meaning that mixture of love and awe, which is specific of the realization of our relation to God. I am not so 
silly as to seek painters to paint religious pictures in the usual sense : for the most part, I know nothing so profoundly profane and godless as our sacred pictures; and I can't say I like our religious beliefs to be symbolized, even as Mr. Hunt has so grandly done in his picture of the Light of the World. But if a painter is himself religious; if he feels God in what he is looking at, and in what he is rendering back on his canvas: if he is impressed with the truly divine beauty, infinity, perfection, and meaning of unspoiled material nature--the earth and the fulness thereof, the heaven and all its hosts, the strength of the hills, the sea and all that is therein ; if he is himself impressed with the divine origin and divine end of all visible things, - then will he paint religious pictures and impress men religiously, and thus make good men better, and possibly make bad men less bad. Take the landscapes of our own Harvey. He is my dear old friend of thirty years, and his power as a painter is only less than his fidelity and ardour as a friend, and that than his simple, deep-hearted piety; I never see one of his transcripts of nature, be they solemn and full of gloom, with a look 'that threatens the profane;' or laughing all over with sunshine and gladness, but I feel something beyond, something greater and more beautiful than their greatness and their beauty-the idea of God, of the beginning and the ending, the first and the last, the 
living One; of whom, and through whom, and to whom are all things; who is indeed God over all, blessed for ever; and whom I would desire, in all humbleness of mind, to sanctify in my heart, and to make my fear and my dread. This is the true moral use of Art, to quicken and deepen and enlarge our sense of God. I don't mean so much our belief in certain articulate doctrines, though I am oldfashioned enough to think that we must know what as well as in whom we believe-that our religion, like everything else, must 'have its seat in reason, and be judicious;' I refer rather to that temper of the soul, that mood of the mind in which we feel the unseen and eternal, and bend under the power of the world to come.

In my views as to the office of the State I hold with John Locke and Coventry Dick, ${ }^{1}$ that its primary, and probably its only function is to protect us from our enemies and from ourselves: that to it is

${ }^{1}$ In the thin octavo, The Office of the State, and in its twin volume on Church Polity, there will be found in clear, strong, and singularly candid language, the first lines of the sciences of Church and State politics. It does not say much for the sense and perspicuity of the public mind, if two such books are allowed to fall aside, and such a farrago of energetic nonsense and error as Mr. Buckle's first, and we trust last, volume on Civilisation, is read, and admired, and bought, with its bad logic, its bad facts, and its bad conclusions. In bulk and in value his volume stands in the same relation to Mr. Dick's, as a handful, I may say a gowpen of chaff does to a grain of wheat, or a bushel of sawdust to an ounce of meal. 
intrusted by the people 'the regulation of physical force ;' and that is indeed little more than a transcendental policeman. This is its true sphere, and here lies its true honour and glory. When it intermeddles with other things, - from your Religion, Education, and Art, down to the number, and size, and metal of your buttons, it goes out of its line and fails; and I am convinced that with some benefits, specious and partial, our Government interference has, in the main and in the long run, done harm to the real interests of Art. Spontaneity, the law of free choice, is as much the life of Art as it is of marriage, and it is not less beyond the power of the State to choose the nation's pictures, than to choose its wives. Indeed there is a great deal on the physiological side to be said for law interfering in the matter of matrimony. I would certainly make it against law, as it plainly is against nature, for cousins-german to marry; and if we could pair ourselves as we pair our live stock, and give ear to the teaching of an enlightened zoonomy, we might soon drive many of our fellest diseases out of our breed; but the law of personality, of ultroneousness, of free will, that which in a great measure makes us what we are, steps in and forbids anything but the convincement and force of reason. Much in the same way, though it be a more trivial matter, pleasure, in order to please, must be that which you yourself choose. You cannot 


\section{Notes on Art.}

make an Esquimaux forswear train oil, and take to tea and toast like ourselves, still less to boiled rice like a Hindoo; neither can you all at once make a Gilmerton carter prefer Raphael and claret to a glass of raw whisky and the Terrific Register. Leviathan is not so tamed or taught. And our Chadwicks and Kaye Shuttleworths and Coles-kings though they may be-enlightened, energetic, earnest, and as full of will as an egg is full of meat, cannot in a generation make the people of England as intelligent as themselves, or as fond and appreciative of the best Art as Mr. Ruskin. Hence all their plans are failing and must fail ; and I cannot help thinking that in the case of Art the continuance of the Cole dynasty is not to be prayed for very much. As far as I can judge, it has done infinitely more harm than good. These men think they are doing a great work, and, worse still, the country thinks so too, and helps them, whereas I believe they are retarding the only wholesome, though slow growth of knowledge and taste.

Take the Kensington Museum: the only thing there (I speak in all seriousness) worth any man spending an hour or a shilling upon, are the Sheepshank and Turner galleries ; all those costly, tawdry, prodigious, and petty displays of arts and manufactures, I look upon as mere delusions and child's play. Take any one of them, say the series illustrating the cotton fabrics; you see the whole course of cotton 
from its Alpha to its Omega, in the neatest and prettiest way. What does that teach? what impression does that make upon any young mind? Little beyond mere vapid wonder. The eye is opened, but not filled; it is a stare, not a look.

If you want to move, and permanently rivet, a young mind with what is worth the knowing, with what is to deepen his sense of the powers of the human mind, and the resources of nature, and the grandeur of his country, take him to a cotton-mill. Let him hear and come under the power of that wonderful sound pervading the whole vast house, and filling the air with that diapason of regulated, harmonious energy. Let him enter it, and go round with a skilled workman, and then follow the Alpha through all its marvellous transformations to the Omega; do this, and you bring him out into the fresh air not only more knowing, but more wise. He has got a lesson. He has been impressed. The same with calico-printing, and pottery, and iron-founding, and, indeed, the whole round of that industry, which is our glory. Do you think a boy will get half the good from the fine series of ores and specimens of pig-iron, and all the steels he may see in cold-blood, and with his grandmother or his sweetheart beside him at Kensington, that he will from going into Dixon's foundry at Govan, and seeing the half-naked men toiling in that place of flame and energy and din 
-watching the mighty shears and the Nasmythhammers, and the molten iron kneaded like dough, and planed and shaved like wood: he gets the dead and dissected body in the one case; he sees and feels the living spirit and body working as one, in the other. And upon all this child's play, this mere make-believe, our good-natured nation is proud of spending some half-million of money. Then there is that impertinent, useless, and unjust system of establishing Government Schools of Design in so many of our towns, avowedly, and, I believe (though it is amazing that clever men should do such a foolish thing) honestly, for the good of the working classes, but actually and lamentably, and in every way harmfully, for the amusement and benefit of the wealthy classes, and to the ruin of the hard-working and legitimate local teachers.

I have not time or space, but if I had I could prove this, and show the curiously deep injuries this system is inflicting on true Art, and upon the freedom of industry.

In the same line, and to the same effect, are our Art-Unions and Associations for 'the encouragement' of Art; some less bad than others, but all bad, because founded upon a wrong principle, and working to a wrong end. No man can choose a picture for another, any more than a wife or a waistcoat. It is part of our essential nature to choose these 
things for ourselves, and paradoxical as it may seem, the wife and the waistcoat and the work of Art our departmental wiseacres may least approve of, if chosen suâ sponte by Giles or Roger, will not only give them more delectation, but do them more good, than one chosen by somebody else for him upon the finest of all possible principles. Besides this radical vice, these Art-Unions have the effect of encouraging, and actually bringing into professional existence, men who had much better be left to die out, or never be born; and it, as I well know, discourages, depreciates, and dishonours the best men, besides keeping the public, which is the only true and worthy patron, from doing its duty, and getting its due. Just take our Edinburgh Association, in many respects one of the best, having admirable and devoted men as its managers, - what is the chance that any of the thousand members, when he draws a prize, gets a picture he cares one straw for, or which will do his nature one particle of good? Why should we be treated in this matter, as we are treated in no way else? Who thinks of telling us, or founding a Royal Association with all its officers, to tell us what novels or what poetry to read, or what music to listen to? Think of a Union for the encouragement of Poetry, where Mr. Tennyson would be obliged to put in his In Memoriam, or his Idylls of the King, along with the Lyrics and the Sonnets of we don't say who, into a common 
lottery, and be drawn for at an annual speechifying! All such associations go to encourage quantity rather than quality. Now, in the ideal and pleasurable arts quality is nearly everything. One Turner not only transcends ten thousand Claudes and Vanderveldes; he is in another sphere. You could not thus sum up his worth.

One of the most flagrant infractions of the primary laws of political economy, and one of the most curious illustrations of the fashionable fallacies as to Government encouragement to Art, is to be found in the revelations in the Report of the Select Committee on the South Kensington Museum. Mr. Lowe, and the majority of the Committee, gave it as their opinion, that Government should deal in photographs, and undersell them (thereby ruining the regular trade), and all for the encouragement of Art, and the enlightenment of the public! Can there be anything more absurd than this, and at this time of day? 'and not only absurd and expensive, but mischievous. All this, you see, would be avoided, and society left to provide its own Art, as it provides its own beef and trowsers for itself; if men would hold with John Locke and Coventry Dick, and Egomet, that Government, the State, has simply nothing to do with these things, that they are ultra vires not less than religion, and, I am bold to add, education.

One other drawback to Art taking its place along- 
side its sisters-Poetry and Music-is the annual Exhibitions. Nothing more thoroughly barbarous and childish could be devised than this concentrating the mental activity of the nation in regard to the Art o the year upon one month. Fancy our being obliged to read all our novels, and all our poetry, and hear all our music in a segment of our year! Then there is the mixing up of all sorts of pictures-sacred and profane, gay and sombre, etc.-all huddled together, and the eye flitting from one to the other. ${ }^{1}$ Hence the temptation to paint down to the gaudiest pictures, instead of up or into the pure intensity of nature. Why should there not be some large public hall to which artists may send their pictures at any time when they are perfected? but, better still, let purchasers frequent the studios, as they did of old, full of love and knowledge. Why will we insist in pressing our Art and our taste, as we did long ago our religion and our God, upon our neighbours? Why not trust to time, and to cultivating our own tastes earnestly, thoroughly, humbly, and for ourselves, filling our houses with the best of everything, and making all welcome to see them, and believing that the grandchildren of those who come to see our Turners and

${ }^{1}$ In our excellent National Gallery (Edinburgh), a copy of Titian's Ariadne in Naxos is hung immediately above Wilkie's sacred sketch of john Knox administering the Sacrament in Calder House ! 
Wilkies and Hogarths will be wiser and more refined than we? It is most lamentable to witness the loss of money, of energy, and in a measure of skill, and, above all, of time, on those engravings, which no one but a lodging-keeper frames, and those Parian statuettes and Etruscan pitchers and tazzas of all sorts, which no one thinks half so much of, or gets half so much real pleasure and good from, as from one of John Leech's woodcuts. One true way to encourage Art is to buy and enjoy Punch. There is more fun, more good drawing, more good sense, more beauty in John Leech's Punch pictures, than in all the ArtUnion illustrations, engravings, statuettes, etc. etc., put together. Could that mighty Potentate have been got up, think you, by a committee of gentlemen, and those drawings educed by proffered prizes? No ; they came out, and have flourished according to a law as natural and as effective as the law of seedtime and harvest; and Art, as a power to do good, will never reach its full perfection till it is allowed to walk at liberty, and follow the course of all other productions, that of supply and demand, individual demand and voluntary supply. It is not easy to tell how far back these well-meaning, zealous, deluded men who have managed these 'encouragements,' have put the progress of the nation in its power of knowing and feeling true Art.

One other heresy I must vent, and that is to pro- 
test against the doctrine that scientific knowledge is of much direct avail to the artist; it may enlarge his mind as a man, and sharpen and strengthen his nature, but the knowledge of anatomy is, I believe, more a snare than anything else to an artist as such. Art is the tertium quid resulting from observation and imagination, with skill and love and downrightness as their executors; anything that interferes with the action of any of these, is killing to the soul of Art. Now, painting has to do simply and absolutely with the surfaces, with the appearances of things ; it knows and cares nothing for what is beneath and beyond, though if it does its own part aright it indicates them. Phidias and the early Greeks, there is no reason to believe, ever dissected even a monkey, much less a man, and yet where is there such skin, and muscle, and substance, and breath of life? When Art became scientific, as among the Romans, and lost its heart in filling its head, see what became of it: anatomy offensively thrust in your face, and often bad anatomy; men skinned and galvanized, not men alive and in action. In the same way in landscape, do you think Turner would have painted the strata in an old quarry, or done Ben Cruachan more to the quick, had he known all about geology, gneiss, and greywacke, and the Silurian system? Turner might have been what is called a better-informed man, but we question if he would have been so good, not to 
say a better representer of the wonderful works of God, which were painted on his retina, and in his inner chamber-the true Camera lucida, the chamber of imagery leading from the other,-and felt to his finger-tips. No; science and poetry are to a nicety diametrically opposed, and he must be a Shakspere and a Newton, a Turner and a Faraday all in one, who can consort much with both without injury to each. It is not what a man has learned from others, not even what he thinks, but what he sees and feels, which makes him a painter.

The moral from all this is, love Art, and if you choose, practise Art. Purchase Art for itself alone, and in the main for yourself alone. If you so do, you will encourage Art to more purpose than if you spent thousands a year in Art-Unions, and in presenting the public with what pleased you; just as a man does most good by being good. Goldsmith puts it in his inimitable way - 'I was ever of opinion that the honest man, who married and brought up a large family, did more service than he who continued single, and only talked of population.'

I have said those things strongly, abruptly, and perhaps rudely; but my heart is in the matter. Art is part of my daily food, like the laughter of children, and the common air, the earth, the sky; it is an affection, not a passion to come and go like the gusty wind, nor a principle cold and dead; it penetrates 
my entire life, it is one of the surest and deepest pleasures, one of the refuges from 'the nature of things,' as Bacon would say, into that enchanted region, that 'ampler æther,' that 'diviner air,' where we get a glimpse not only of a Paradise that is past, but of a Paradise that is to come.

There is one man amongst us who has done more to breathe the breath of life into the literature and the philosophy of Art, who has 'encouraged' it ten thousand times more effectually than all our industrious Coles and anxious Art-Unions, and that is the author of Modern Painters. I do not know that there is anything in our literature, or in any literature, to compare with the effect of this one man's writings. He has by his sheer force of mind, and fervour of nature, the depth and exactness of his knowledge, and his amazing beauty and power of language, raised the subject of Art from being subordinate and technical, to the same level with Poetry and Philosophy. He has lived to see an entire change in the public mind and eye, and, what is better, in the public heart, on all that pertains to the literature and philosophy of representative genius. He combines its body and its soul. Many before him wrote about its body, and some well; a few, as Charles Lamb and our great 'Titmarsh,' touched its soul: it was left to John Ruskin to do both. ${ }^{1}$

${ }^{1}$ This great writer was first acknowledged as such by our big 


\section{DISTRAINING FOR RENT.}

OF this picture it is not easy to speak. We do not at first care to say much about feelings such as it produces. It is, to our liking, Wilkie's most perfect picture. If they were all to be destroyed but one, we would keep this. His 'Blind Man's Buff,' his 'Penny Wedding,' his ' Village Politicians,' and many others, have more humour, - his 'John Knox preaching,' more energy,--his 'John Knox at the Sacrament,' more of heaven and victorious faith ; quarterlies, in the North British Review, fourteen years ago, as follows :-

'This is a very extraordinary and a very delightful book, full of truth and goodness, of power and beauty. If genius may be considered (and it is as serviceable a definition as is current) that power by which one man produces for the use or the pleasure of his fellow-men, something at once new and true, then have we here its unmistakable and inestimable handiwork. Let our readers take our word for it, and read these volumes thoroughly, giving themselves up to the guidance of this most original thinker, and most attractive writer, and they will find not only that they are richer in true knowledge, and quickened in pure and heavenly affections, but they will open their eyes upon a new world-walk under an ampler heaven, and breathe a diviner air. There are few things more delightful or more rare, than to feel such a kindling up of the whole faculties as is produced by such a work as this ; it adds a 'precious seeing to the eye,'makes the ear more quick of apprehension, and, opening our whole inner man to a new discipline, it fills us with gratitude as well as admiration towards him to whom we owe so much enjoyment. And what is more, and better than all this, every where throughout this work, we trace evidences of a deep rever- 
but there is more of human nature, more of the human heart, in this, than in any of the others. It is full of 'The still, sad music of humanity;'

still and sad, but yet musical, by reason of its true ideality, the painter acting his part as reconciler of men to their circumstances. This is one great end of poetry and painting. Even when painful and terrible in their subjects, 'they are of power, by raising pity and fear or terror, to purge the mind of suchlike passions, - that is, to temper and reduce them to just measure with a kind of delight;' or, in the words of Charles Lamb, 'they dispose the mind to a meditative tenderness.'

ence and godly fear-a perpetual, though subdued acknowledgment of the Almighty, as the sum and substance, the beginning and the ending of all truth, of all power, of all goodness, and of all beauty.

'This book (Modern Painters) contains more true philosophy, more information of a strictly scientific kind, more original thought and exact observation of nature, more enlightened and serious enthusiasm, and more eloquent writing, than it would be easy to match not merely in works of its own class, but in those of any class whatever. It gives us a new, and we think the only true theory of beauty and sublimity; it asserts and proves the existence of a new element in landscape painting, placing its prince upon his rightful throne; it unfolds and illustrates, with singular force, variety, and beauty, the laws of art ; it explains and enforces the true nature and specific function of the imagination, with the precision and fulness of cne having authority,-and all this delivered in language which, for purity and strength and native richness, would not have dishonoured the early manhood of Jeremy Taylor, of Edmund Burke, or of the author's own favourite Kichard Hooker.'-J. B. 
But to return to this most touching and impressive picture. What an immediate hold it took of us! How that sad family was in our mind for days after, and how we found ourselves wondering if nothing could be done for them! It is just about as difficult to bring the mind to criticise it, as it would be to occupy ourselves in thinking why and how we were affected, if we were ourselves to witness the scene in actual life. We would be otherwise occupied. Our eyes first fell on what is the immediate occasion of it all, the paper warrant; you feel its sharp parallelogram cutting your retina, it is the whitest, and therefore the first thing you see ; and then on the husband. What utter sadness,what a sober certainty of misery,-how uncomplaining, as if he could not speak, his firm mouth keeping it to himself! His eyes are all but shut,-how their expression is given, seems to us quite marvellous ; and his attitude cast down, but not abject-bearing it like a man. How his fingers are painted, and his careless, miserable limbs, his thin cheek, with that small hungry hollow mark in its centre! What a dignity and beauty in his face! This is to us a finer head than the wonderful one in Retzsch's 'Man playing at Chess with the Devil for his Soul,' and this is not saying little. Reason and steady purpose are still uppermost.

Not so with his poor wife : her heart is fast failing; 
she is silent too; but she is fainting, and just about to slip off her chair in utter unconsciousness; her eyes are blind; the bitterness of death is gathering on her soul. She is forgetting her sucking child, as she is all outward things; it is rolling off her knee, and is caught by her motherly daughter; while her younger brother, whose expressive back is only seen, is pulling his father's coat, as if to say, 'Look at mother!' Behind are two neighbours come in, and sympathizing both, but differently; the meek look of the one farthest away, what can be finer than that! The paleness of the fainting mother is rendered with perfect truth. What an eye the painter must have had!-how rapid, how true, how retentive of every impression! Behind these silent sufferers goes on the action of the story. The brother, a young, goodlooking, fearless fallow; is shaking his fist and fixing his angry eyes on the constable, who returns the look as resolutely, but without anger. This figure of the constable is in many respects as astonishing as anything in the picture. He is 'a man with a presence' -inexorable, prompt, not to be trifled with; but he is not, as many other artists would have made him, and wished us to call him, 'the brutal Bailiff.' He is doing his duty, as he is plainly saying, pointing to his warrant, and nothing more : he cannot help it, and the law must have its course. What a fine figure he is, the only one standing erect, and what rich 


\section{Notes on Art.}

colour in his waistcoat! Seated on the bed is the smart, indifferent clerk, with his pale, smug countenance. A man of business, and of nothing else, he seems to be running up the value of these bedclothes,-that bed, with its sad-coloured curtains, and all its memories of births and deaths. Behind is a man whose face we don't exactly make out: he has a sleepy, tipsy, altogether unknowable sort of expression. We don't think this a defect in the painter: it is the most likely thing in the world that such a person would be there.

Then comes the cobbler, straight from his stall, where, as from a throne, he dispenses his 'think,'and a strong think it is,- to all comers, upon all subjects. He has opinions of his own about most things, but chiefly upon civil, ecclesiastical, and marital jurisdiction, ' with a power of law' in him. He is enjoining submission and composure upon all onlookers. His hands, how they speak! the one to the bailiff, deferential, confidential, gently deprecatory ; the other, to the company in general, imperative, final, minatory. He is vindicating the law, and laying it down somewhat unseasonably, and is even hinting that they should rejoice at its arrangements. That brave old woman, inspired by anger, is bearing down upon both cobbler and bailiff, with occasional darts of her furious eye at the unconscious clerk. This woman's face is expressive beyond all descrip- 
tion. Look at her fore-finger, as straight, as wellaimed, as unmistakably deadly in intention, as a sword, or rather pistol; and, could intensity of will have made it fire, we may reckon on its shot having been soon into the stately bailiff. But she has a sword in her tongue: how it is plying its work from behind these old straggling teeth!-no man can tame it ; and her cruel, furious eyes, aiming every word, sending it home.

How well Shakspere describes this brilliant old lady :- 'She is misusing him past the endurance of a block : an oak with but one green leaf would have answered her. She huddles jest upon jest, with such impossible conveyance, that he stands like a man at a mark, with a whole army shooting at him !'

What a contrast to her, the woman behind, 'her face foul with weeping,' crying her very eyes and soul out, like a child!

What a picture! so simple, so great, so full (to use a word of Wilkie's own) of intellectuality-and the result, though sad, salutary. How strange! We never saw these poor sufferers, and we know they have no actual existence; and yet our hearts go out to them,- we are moved by their simple sorrows. We shall never forget that enduring man and that fainting mother.

There is another personage yet to speak of. Some of our readers may never have seen him: we can 
assure them he has seen them. This is the dog,the family dog,- - the friend of them all, from baby upwards. We find him just where he should be, and at his own proper work. He is under his master's chair, and at his feet, looking out from between his legs. His master, as Burns has with wonderful meaning expressed it, is his god. 'Man is the god of the dog.' ${ }^{1}$ How much may we learn from this !

With that fine instinct, compounded of curiosity, experience, and affection, he has made his observations on the state of things! All is not right, he sees,- - something very far wrong. He never before saw her look in that way, or him. so quiet and strange. Accordingly, as he is eminently practical, and holds with Hume and many great men, that all we know of causation is one thing following upon another (being a dog, and not a philosopher, he pays no attention to the qualification 'invariably'), and, putting two things together, he finds this dismal, unintelligible state of matters following upon the entrance of these three strange men. He has been doing diligence, and serving and executing warrants, in his own wild and vigorous way, upon their six legs - specially, we doubt not, upon the tight pantaloons of that cold-blooded clerk. They are so tempting! Having been well kicked by all

${ }^{1}$ I am wrong in this. Bacon first uses this thought in his Essay on Atheism. Burns improves it. 
for his pains, he has slunk into his den, where he sits biding his time. What a pair of wide awake, dangerous eyes! No 'speculation' in them-no looking before or after; but looking into the present-the immediate. Poor fellow, his spare diet for some time back-his half-filled bicker-have not lessened his natural acuteness, his sharpness of teeth and temper. Our readers will, we fear, be tired of all this about a dog, and 'such a vulgar little dog.' We happen to hold high views on the moral and social bearings of dogs, especially of terriers, those affectionate and great-hearted little ruffians; but as our friends consider us not sane on this point, and as we (as is common in such cases) think quite the reverse, we shall not now dispute the matter. One thing we may say, that we are sure Wilkie would have taken our side. He has a dog, and often more, in almost every one of his pictures; and such dogs! not wee men in hairy skins, pretending to be dogs. His dogs are dogs in expression, as well as in body. Look, in his engravings, at the dog in the 'Rent Day;' in 'Blind Man's Buff,' that incomparable one, especially, who is flattened hopelessly and ludicrously under the weight of a chair and a man-how utterly quenched, and yet how he is giving a surly grin at his own misery; and the dog in the Gentle Shepherd, as gentle as his master; and that great-headed mastiff 
under the gun-carriage - a very ' dog of war' - in 'The Maid of Saragossa' - to us the hero of the picture; and, above all, the little pet dog in the 'Only Daughter'-its speaking, imploring ways, as it looks to its dying mistress. What a wonderful art! We cannot leave this inestimable picture, without expressing our personal gratitude to our public-spirited Academy for furnishing us every year with some of this great master's works. We trust we shall have one of his, and one of Turner's every year. They elevate public feeling; they tend, like all productions of high and pure genius, to the glory of God, and the good of mankind; they are a part of the common wealth. We end our notice of this picture by bidding our readers return to it, and read it over and over, through and through. Let them observe its moral effect-not to make the law and its execution hateful or unsightly, or vice or improvidence interesting or picturesque. Wilkie takes no side but that of our common nature, and does justice to the bailiff as well as to the distressed family. We have here no hysterical passions - no shaking of fists against the heavens, and sending up thither mingled blasphemy and prayer, as some melo-dramatic genius might have done. Let them remark the stillness of the great sufferers, and how you know what they have come throughthe consummate art in arranging the parts of the 
subject-its simplicity at first-its fulness afterwards when looked into-more in it than meets the eye. Mind must be exercised upon it to bring cut its mind. The white table-cloth, leading the eye at once to the heart of the picture; the table dividing the two groups, and preventing its being a crowd; the figure of the father given entire, indicating his total dejection from head to foot,- - his hands, his finger-nails, - the dignity and self-containment of his sorrow : all the hands are wonderful, and above all, as we have noticed, the cobbler's; - the general air of the house not squalid-no beggarly elements - no horrors of actual starvation-all respectable, and poverty-stricken and scrimp;-the bone lying on the floor, on which our small four-footed Spartan may have been rehearsing his 'Pleasures of Memory,' and whiling and whittling away his idle hours, and cheating his angry hunger; - the bed -its upright posts - the stately Bailiff alone as erect and firm; - the colour of the curtains - their very texture displayed; the colouring sober, powerful, not loud (to borrow from the ear); - the absence of all effort, or mere cleverness, or pretension ; no trace of handicraft; you know it to be painted-you do not feel it; the composition as fine, as musical, as Raphael's; - - the satisfying result; your whole nature, moral and affectionate-your inward and outward eye-fed with food convenient for them. 


\section{Notes on Art.}

It has long been a question in the ethics of fiction, whether sympathy with ideal sorrows be beneficial or mischievous. That it is pleasurable we all know. And a distinction has been made between pity as an emotion ending with its own gratification, and pity as a motive, a moving power, passing, by a necessity of its nature, into action and practical performance.

But, without going into the subject, we may give, as a good practical rule, let your moral sense be so clear and healthy as to discern at once the genuine objects of pity; and then, let them be fictitious or real, you may pity them safely with all your might. In either case you will get good, and the good will not end with yourself, even in the first case.

The story of Joseph, for instance, is to us fictitious, or rather, it is ideal; and in weeping over him, or over his heart-broken father, we know we can do them no good, or give them no sympathy; but where will you find a merely human story more salutary, more delightful, more appropriate, to every one of our intellectual, moral, and, let us add, our imaginative and æsthetical faculties?

We are inclined to rank Hogarth and Wilkie as the most thoughtful of British painters, and two of the greatest of all painters.

Some people, even now, speak of Hogarth as being at best a sort of miraculous caricaturist, and a shockingly faithful delineator of low vice, and misery, and 
mirth, but deficient in knowledge of the human figure, and in academical skill, and as having fallen short of the requirements of ' high art.'

We thought Charles Lamb had disposed of this untruth long ago; and so he did. But some folks don't know Charles Lamb, and we shall, for their sakes, give them a practical illustration of his meaning, and of ours. If Hogarth did not know the naked human figure (and we deny that he did not), he knew the human face and the naked human heart-he knew what of infinite good and evil, joy and sorrow, life and reath, proceeded out of it. Look at the second last of the series of 'Mariage à la Mode.'

If you would see what are the wages of sin, and how, after being earned, they are beginning to be paid, look on that dying man,--his body dissolving, falling not like his sword, firm and entire, but as nothing but a dying thing could fall, his eyes dim with the shadow of death, in his ears the waters of that tremendous river, all its billows going over him, the life of his comely body flowing out like water, the life of his soul !- who knows what it is doing? Fleeing through the open window, undressed, see the murderer and adulterer vanish into the outer darkness of night, anywhere rather than remain ; and that guilty, beautiful, utterly miserable creature on her knee, her whole soul, her whole life, in her eyes, fixed on her dying husband, dying for and by her! 
What is in that poor desperate brain, who can tell: Mad desires for life, for death,-prayers, affections, infinite tears,- - the past, the future,-- -her maiden innocence, her marriage, his love, her guilt,- - the grim end of it all,- - the night-watch with their professional faces, - the weary wind blowing through the room, the prelude, as it were, of that whirlwind in which that lost soul is soon to pass away. The man who could paint so as to suggest all this, is a great man and a great painter.

Wilkie has, in like manner, been often misunderstood and misplaced. He is not of the Dutch school, - he is not a mere joker upon canvas, - he can move other things besides laughter; and he rises with the unconscious ease of greatness to whatever height he chooses. Look at John Knox's head in 'The Administering the Sacrament in Calder House.' Was the eye of faith ever so expressed,--the seeing things that are invisible?

Hogarth was more akin to Michael Angelo: they both sounded the same depths, and walked the same terrible road. Wilkie has more of Raphael,- -his affectionate sweetness, his pleasantness, his grouping, his love of the beautiful.

\section{THOMAS DUNCAN.}

Duncan possessed certain primary qualities of mind, without which no man, however gifted, can 
win and keep true fame. He had a vigorous and quick understanding, invincible diligence, a firm will, and that combination, in action, of our intellectual, moral, and physical natures, which all acknowledge, but cannot easily define, manliness.

As an artist, he had true genius, that incommunicable gift, which is born and dies with its possessor, never again to reappear with the same image and superscription. The direction of this faculty in him was towards beauty of colour and form,-its tendency was objective rather than subjective; the outward world came to him, and he noted with singular vigilance and truth all its phenomena. His perception of them was immediate, intense, and exact, and he could reproduce them on his canvas with astonishing dexterity and faithfulness. This made his sketches from nature quite startling, from their direct truth. There are two of them in Mr. Hay's gallery,- -one, a girl with her bonnet on, sitting knitting at a Highland fireside ; the other, a quaint old vacant room in George Heriot's Hospital.

But his glory, his peculiar excellence, was his colouring; there was a charm about it, a thing that could not be understood, but was felt. How transparent its depth,-—how fresh,-_how rich to gorgeousness,-how luminous, as from within!

His power over expression was inferior to his colouring. Not that he can be justly said to have 
failed in his exercise of this faculty; he rather did not attempt its highest range. His mind lingered delighted, at his eye ; and if his mind did proceed inwards, it soon returned, and contented itself with that form of expression which, if we may so speak, lies in closest contact with material beauty. Therefore it is that he often brought out, with great felicity and force, some simple feeling, some fixed type of character common to a class, but did not care to ascend to the highest heaven of invention, or stir the depths of imagination and passion. Nature was perceived by him, rather than imagined; and he transferred rather than transfigured her likeness. As a consequence, his works delight more than move, interest more than arrest. In a remarkable sketch left behind him of an intended picture of Wishart administering the Sacrament before his execution, there is one truly ideal head,- - a monk, who is overlooking the touching solemnity, and in whose pinched, withered face are concentrated the uttermost bigotry, malice, and vileness of nature, his cruel small eyes gleaming as if 'set on fire of hell.' Duncan's mind was romantic, rather than historical. We see this in his fine picture of 'Prince Charles's Entry into Edinburgh.' He brings that great pageant out of its own time into ours, rather than sends us back to it. 'This arose, as we have said, from the objective turn of his mind; and would have rendered him unsurpassed in 
the representation of contemporaneous events. What a picture, had he lived, would he have made of the Queen at Taymouth! the masterly, the inimitable sketch of which is now in the Exhibition. We have an ancient love of one of his early pictures,- 'Cuddy Headrig and Jenny Dennistoun.' Cuddy has just climbed up with infinite toil ; and, breathless with it and love, he is resting on the window-sill on the tips of his toes and fingers, in an attitude of exquisite awkwardness, staring, with open mouth and eyes, and perfect blessedness, on his buxom, saucy Jenny. Duncan's fame will, we are sure, rest chiefly on his portraits. They are unmatched in modern times, except by one or two of Wilkie's, and that most noticeable 'Head of a Lady,' by Harvey, in the inner octagon. Duncan's portraits are liker than their originals. He puts an epitome of a man's character into one look. The likeness of Dr. Chalmers has something of everything in him,- - the unconsciousness of childhood, - the fervour of victorious manhood,- the wise contemplativeness of old age,the dreamy inexpressive eye of genius, in which his soul lies, 'like music slumbering on its instrument,' ready to awake when called-the entire loveableness of the man - the light of his countenance,- - his heavenly smile,-are all there, and will carry to after times the express image of his person. How exquisite the head of D. O. Hill's daughter! so full of 
love and simpleness, the very realization of Wordsworth's lines:

'Loving she is, and tractable, though wild, And innocence hath privilege in her To dignify arch looks and laughing eyes, And feats of cunning.'

There was something mournful and touching in the nature and progress of the last illness of this great artist. His unresting energy, his manly diligence, urged him beyond his powers; his brain gave way, and blindness crept slowly on him. It was a sort of melancholy consolation that, as the disease advanced, his intense susceptibility and activity were subdued, when their exercise must have only produced misery and regret. What is now infinitely more important is, that those who knew him best have little doubt, that while the outward world, with its cares, its honours, its wondrous beauty, its vain shows, was growing dim, and fast vanishing away, the eyes of his understanding became more and more enlightened, and that he died in the faith of the truth. If so, he is, we may rest assured, in a region where his intense perception of beauty, his delight in all lovely forms, and in the goodliness of all visible things, will have full exercise and satisfaction, and where that gift which he carries with him as a part of himself will be dedicated to the glory of its Giver,the Father of Lights. 
We believe it to be more than a pleasant dream, that in the regions of the blessed each man shall retain for ever his innate gifts, and shall receive and give delight by their specific exercise. Such a thought gives, as it ought, to this life an awful, but not undelightful significance. $\mathrm{He}$ who, in his soul, and by a necessity of his nature, is a poet or a painter, will, in a spiritual sense, remain so for ever.

\section{PALES'TRINA.}

We miss Turner's great landscape, 'Palestrina,' with its airy fulness and freedom,-its heaven and earth making one imagery,-its daylight, its sunlight, its magical shadows, - that city set upon a hill, each house clinging to the rocks like swallows' nests,-its waters murmuring on for ever, and sending up their faint steam into the fragrant air, that oblique bridge, so matchlessly drawn,- those goats browsing heedless of us, - in one word, its reality, and its something more!

One day last year, while waiting for a friend, we sat down in the rooms, and were thinking of absent things; some movement made us raise our eyes, and for that instant we were in Italy. We were in the act of wondering what we should see, when we reached the other end of that cool and silent avenue ; and if one of these goats had looked up and stared 
at us, we should have hardly been surprised. It har, while it lasted, 'the freshness and the glory of a dream.'

We shall never forget this picture. It gave us a new sensation, a new and a higher notion of what the mind of man can put into, and bring out of, landscape painting; how its representative and suggestive truthfulness may be perfect, forming the material elements, - the body, as it were, of the picture,-while, at the same time, there may be superadded that fine sense of the undefinable relation of the visible world to mental emotion, which is its essence and vivifying soul.

How original, how simple, its composition! That tall tree, so inveterately twisted on itself, dividing the scene into two subjects, each contrasting with and relieving the other; the open country lying under the full power of the flaming mid-day sun ; and that long alley, with its witchery of gleam and shadow, its cool air, a twilight of its own, at noon!

Nothing is more wonderful about Turner than the resolute way in which he avoids all imitation, even when the objects are in the very foreground and clearly defined. He gives you an oak, or a beech, or an elm, so as to be unmistakable, and yet he never thinks of giving their leaves botanically, so as that we might know the tree from a leaf. He gives us it not as we know it, but as we should see it from 
that distance; and he gives us all its characteristics that would carry that length, and no more. He is determined to give an idea, not a copy, of an oak. This is beautifully seen in his 'Ivy Bridge,'- - picture, the magical simplicity of which grows upon every look. There is a birch there, the lady of the wood, which any nurseryman would tell you was a birch; and yet look into it, and what do you see? Turner sets down results of sight, - not the causes of these results. His way is the true æsthetic,-the other is the scientific.

\section{HUNT THE SLIPPER.}

We plead guilty to an inveterate, and, it may be, not altogether rational, antipathy to Mr. Maclise's pictures. As vinegar to the teeth, as smoke to the eyes, or as the setting of a saw to the ears, so are any productions of his pencil we have met with to our æsthetic senses. We get no pleasure from them except that of hearty anger and strong contrast. Their hot, raw, garish colour-the chalky dry skin of his women - the grinning leathern faces of his menand the entire absence of toning-are as offensive to our eyesight as the heartlessness, the grimace, the want of all naturalness in expression or feeling, in his human beings, are to our moral taste.

There is, no doubt, wonderful cleverness and 


\section{Notes on Art.}

facility in drawing legs and arms in all conceivable positions, considerable dramatic power in placing his figures, and a sort of striking stage effect, that makes altogether a smart, effective scene; and if he had been able to colour like Wilkie, there would have been a certain charm about them. But you don't care-at least we don't care-to look at them again; they in no degree move us out of ourselves into the scene. They are so many automata, and no more. To express shortly, and by example, what we feel about his picture of 'Hunt the Slipper,' we would say it is in all points the reverse of Wilkie's picture opposite, 'The Distraining for Rent,' in colour, conception, treatment, bodily expression, spiritual meaning, moral effect. Mr. Maclise's women are pretty, not beautiful ; prim, not simple: their coyness, as old Fuller would say, is as different from true modesty as hemlock is from parsley - there is a meretriciousness about them all, which, as it is entirely gratuitous, is very disagreeable. The vicar is not Oliver Goldsmith's Dr. Primrose.

The best thing in the picture is the mantelpiece, with its odds and ends: the china cups and saucers, and that Hindu god, sitting in dropsical dignitythese are imitated marvellously, as also is the old trunk in the right corner. As far as we have seen, Mr. Maclise's gift lies in this small fancy line. We remember some game and a cabinet in his 'Robin 
Hood,' that would have made Horace Walpole or our own Kirkpatrick Sharpe's mouth water; the nosegays of the two London ladies are also cieveriy painted, but too much of mere fac-similes. Nothing can be worse in colour or in aërial perspective than the quaint old shrubbery seen through the window; it feels nearer our eye than the figures. As to the figures, perhaps the most life-like in feature and movement are the two bad women, Miss Carolina Wilhelmina Amelia Skeggs and Lady Blarney.

The introduction of them into the story is almost the only blemish of that exquisite piece, and we have still less pleasure in seeing their portraits. How different from Hogarth's terrible pictures of the same miserable class! There you see the truth; you can imagine the past and the future, as well as perceive the present. Beauty, grace, often tenderness, sinking into ruin under the steady influence of a life of sin, make them objects at once of our profoundest compassion - and of our instant reprobation. But we must stay our quarrel with Mr. Maclise. We have perhaps been unlucky in the specimens of his genius that we have seen-the only other two being the 'Bohemians' and 'Robin Hood;' the first a picture of great but disagreeable power-a sort of imbroglio of everything sensual and devilish-the very superfluity of naughtiness- 
as bad, and not so good as the scene in the Brocken in Goethe's Faust. Mr. Maclise may find a list of subjects more grateful to the moral sense, more for his own good and that of his spectators, and certainly not less fitted to bring into full play all the best powers of his mind, and all the craft of his hand, in Phil. iv. 8.

'Robin Hood' was rather better, because there were fewer women in it; but we could never get beyond that universal grin which it seemed the main function of Robin and his 'merrie men' to sustain. Of the landscape we may say, as we did of his figures and Wilkie's, that it was in every respect the reverse of Turner's.

We have been assured by those whose taste we know in other matters to be excellent, that Mr. Maclise is a great genius, a man of true imagination; and that his 'Sleeping Beauty,' his scene from Macbeth, and some others, are the proofs of this. We shall wait till we see them, and hope to he converted when we do; but, meanwhile, we suspect that his Imagination may turn out to be mere Fancy, which are as different, the one from the other, as word-wit is from deep humour, or as Queen Mab (a purely fanciful description) is from Miranda or Ariel. Fancy is aggregative and associative, - Imagination is creative, motive. As Wordsworth in one of his prefaces beautifully says, 
- The law under which the processes of Fancy are carried on is as capricious as the accidents of things, and the effects are surprising, playful, ludicrous, or pathetic, as the objects happen to be appositely produced or fortunately combined. Fancy depends upon the rapidity and profusion with which she scatters her thoughts and images, trusting that their numbers, and the felicity with which they are linked together, will make amends for the want of individual value; or she prides herself upon the curious subtlety, and the successful elaboration, with which she can detect their lurking affinities. If she can win you over to her purpose, she cares not how unstable or transitory may be her influence, knowing that it will not be out of her power to resume it on apt occasion. But Imagination is conscious of an indestructible dominion,- the soul may fall away from it, not being able to sustain its grandeur; but if once felt and acknowledged, by no other faculty of the mind can it be relaxed, impaired, or diminished. Fancy is given to quicken and beguile the temporal parts of our nature, - Imagination to awaken and to support the eternal.' The one is the plaything, the other the food, the elixir of the soul. All great poets, as Homer, Shakspere, Milton, and Burns, have both faculties, and find fit work for each; and so have the great painters, Titian, Veronese, Albert Durer, Hogarth, Wilkie. We sus- 


\section{Notes on Art.}

pect Mr. Maclise has little else than fancy, and makes it do the work of both. There must be something radically defective in the higher qualities of poetic sensibility and ideality in any man who could, as he has done in the lately published edition of Moore's Melodies, execute some hundreds of illustrations, without above three or four of them being such as you would ever care to see again, or, indeed, would recognise as having ever seen before.

We would not give such sweet humour, such maidenly simpleness, such exquisite mirth, such 'quips, and cranks, and wanton wiles,' as we can get in most of the current numbers of 'Punch,' from the hand of young Richard Doyle (I846), with drawing quite as astonishing, and far more expression,--for this sumptuous three-guinea quarto. Have our readers six-and-sixpence to spare? - then let them furnish wholesome fun and 'unreprovèd pleasure' for the eyes and the minds of the small men and women in the hursery, by buying "The Fairy Ring,' illustrated by him.

\section{THREE LANDSEERS.}

It would not be easy to say which of these three delightful pictures gives the most delight; only, if we were forced to name which we should best like 
to possess, we would say, 'Uncle Tom and his Wife for Sale,'-one of the most wonderful bits of genius and its handiwork we ever had the pleasure of enjoying and being the better of.

The others are 'The Maid and the Magpie,' and 'The Pen, the Brush, and the Chisel,'-the latter presented by Lady Chantrey to Her Majesty, and having for its subjects Chantrey's well-known bust of Sir Walter in the clay, with the sculptor's tools lying beside it, and his finger prints, fresh and soft, full of thought and will, giving a fine realization of work going on. The expression of the then Great Unknown is very noble-he looks like a mighty shade; beside the bust is a terrier, such as only Sir Edwin can give, with a keen look, as if he too smelt some one. Two woodcocks are resting in front in a fold of the tablecloth; doubtless the two famous birds which Sir Francis brought down at one shot, and immortalized in marble. At the corner of the picture, and stealthily peering from behind the table-cloth, is a cat's head, not yet seeing the game, but nosing it. You can easily imagine the lively scrimmage when puss makes herself and her ends known, and when the unsuspected 'Dandie' comes down upon her. The feeling and workmanship of this beautiful conceit is such as no one else could originate and express.

'The Maid and the Magpie' is a rustic tragedy 


\section{Notes on Art.}

told at a glance. It is milking-time, in a dreamy summer-day. Phillis,

'So buxom, buthe, and debonair,'

is filling her pail, her meek-eyed, lady-like cowshe is a high-bred Alderney-enjoying herself as cows know why during this process of evacuation and relief. Her glum, unsatisfied calf, who has been all the morning protesting and taking instruments, and craving extracts, and in vain, is looking and listening, hungry and sulky; he never can understand why he gets none of his mother's, of his own milk; - the leather muzzle, all bristling with sharp rusty nails, tells his miseries and his mother's too. Thestylis is leaning forward, awkward and eager, at the door, making love to Phillis in his own clumsy and effective way, whittling all the while destructively at the door-post with his knife. It is the old, old story. She has her back turned to him, and is pretending to be very deep in the milking, while her eye-which you see, and he doesn't-says something quite else. In the right corner are two goats, one a magnificent rugged billy. On the green beyond, in the sunshine, may be seen the geese making off on feet and wings to the well-known 'henwife,' who is at the wicket with her punctual mess. Among the trees, and up in the cloudless, sunny air, is the village spire, whose bells Thestylis doubtless hopes some day soon to set a ringing. All very pretty and inno- 
cent and gay. But look in the left corner, -as if he had this moment come in, he is just hopping into their paradise,-is that miscreant magpie, who, we all know, was a pilferer from the beginning, and who next moment, you know, will have noiselessly grabbed that fatal silver spoon in the posset-cup,which Phillis can't see, for her heart is in her eye,this same spoon, as we all know, bringing by and by death into that little world, and all their woe. We never remember the amari aliquid coming upon us so unawares, ugly and fell, like that old Toad squat at the ear of Eve. The drawing, the expression, the whole management of this little story, is exquisite. Perhaps there is a little over-crowding and huddling together in the byre; but it is a delicious picture, as wholesome and sweet as a cow's breath. You hear the music of the milk playing in the pail; you feel the gentle, rural naturalness of the whole scene.

Of ' Uncle Tom and his Wife for Sale,' it is not easy to speak in moderation, as assuredly it is impossible to look at it, and keep from bursting into tears and laughter all at once. Anything more saturated, more insufferably overflowing with the best fun and misery, with the oddest, homeliest humour and despair, we never before encountered.

' Uncle Tom' is a small, old, dusky bull-dog, with bandy legs and broad chest, and an amazing look of 


\section{Notes on Art.}

a nigger. His eyes are crunched up in an ecstasy of woe, the crystal tears hailing down his dark and knobby cheeks, 'which witness huge affliction;' his mouth is open to the full, and one black stump is all we see of teeth ; his tongue, out to the utmost, quivering with agitation and panting, - a tongue, the delicate, moist pink of which, like the petal of some tropical flower, is in wonderful contrast to the cavern -the jaws of darkness - out of which it is flung. And what is all this for? Is he in pain? No. Is he afraid? Not he; that is a sensation unknown to Tom. He is plainly as full of pluck, as 'game' as was ever Crib or Molyneux. He is in this state of utter woe, because he is about to be sold, and his wife, 'Aunt Chloe,' the desire of his old eyes, may be taken from him, the mere idea of which has put him into this transport, so that he is written all over with lamentation, utterly begrutten, and done for. It is this touching combination of immense affection and ugliness, which brings out the pathetic-comic effect instantly, and to the uttermost. We never saw anything like it except Mr. Robson's Medea. Why is it that we cannot but laugh at this? It is no laughing matter with the honest and ugly and faithful old beast.

Chloe, who is chained to Tom, is, with the trick of her sex, sinking her own grief in sorrow for his. She is leaning fondly towards him, -and looking up to him 
with a wonderful eye, anxious to comfort him, if she knew how. Examine the painting of that congested, affectionate organ, and you will see what true work is. And not less so the bricks which form the background; all represented with the utmost modesty and truth, not only of form and colour, but of texture.

\section{THE RANDOM SHOT.}

If any one wishes to know how finely, and to what fine issues, the painter's spirit and his own may be touched, how much of gentleness may be in power, how much of power in gentleness, let him peruse the 'Random Shot' by Landseer.

On the summit of some far remote Highland mountain, on the untrodden and azure-tinted snow, lies a dead or dying hind, its large brown velvety ears set off against the pure, pearly, infinite sky, into whose cloudless depths the darkness of night is already being poured. The deep, unequal footsteps of the miserable mother are faintly traced in blood, her calf is stooping down, and searching for its comfortable and ever-ready drink, but finding none. Anything more exquisite than this long-legged, bewildered creature, standing there all forlorn, stupid and wildhunger and weariness, fear and amazement, busy at its poor silly heart-we have never seen in painting. By the long shadows on the snow, the delicate green 
tint of the sky, the cold splendour on the mountain tops, and the gloom in the corries, we know that day is fast going, and night with all her fears drawing on, and what is to become of that young desolate thing?

This is not a picture to be much spoken about; it is too quick with tenderness, and reaches too nicely that point which just stops short of sadness; words would only mar its pathetic touch.

Here is another by the same painter, which, though inferior and very different in subject, is not less admirable in treatment. It consists of the portraits of three sporting dogs. A retriever, with its sonsy and affectionate visage, holding gingerly in its mouth a living woodcock, whose bright and terror-stricken eye is painted to the life. In the centre is a keen thoroughgoing pointer, who has just found the scent among the turnips. This is perhaps the most masterly among the three, for colour and for expression. The last is a liver-coloured spaniel, panting over a plump pheasant, and looking to its invisible master for applause. The touch of genius is over them all, everywhere, from the rich eye of the retriever to the wasted turnip-leaves. Yet there is no mere cleverness, no traces of handiwork; you are not made to think of work at all, till you have got your fill of pleasure and surprise, and then you wonder what cunning brain, and eye, and finger could have got so much out of so little, and so common. 
We often hear of the decline of the Fine Arts in our time and country, but any age or nation might well be proud of having produced within fifty years, four such men as Wilkie, Turner, Etty, and Landseer.

\section{THE EXECUTION OF LADY JANE GREY.}

There is an immediateness and calm intensity, a certain simplicity and tragic tenderness, in this exquisite picture, which no one but Paul Delaroche has in our days reached. You cannot escape its power, you cannot fail to be moved; it remains in your mind as a thing for ever. It is the last scene of that story we all have by heart, of

'Her most gentle, most unfortunate.'

That beautiful, simple English girl, the young wife, who has just seen the headless body of her noble young husband carried past, is drawing to the close of her little life of love and study, of misery and wrong. She is partially undressed, her women having disrobed her. She is blindfolded, and is groping almost eagerly for the block; groping as it were into eternity; her mouth slightly open, her face 'steady and serene.' Sir John Gage, the Constable of the Tower, is gently leading her by the left hand to the block, and gazing on her with a surprising compassion and regard - a very noble 
head. Her women, their work over, are aside; one fallen half-dead on the floor; the other turning her back, her hands uplifted and wildly grasping the stone pillar, in utter astonishment and anguish. You cannot conceive what that concealed face must be like. We don't remember anything more terrible or more intense than this figure. In the other corner stands the headsman, with his axe ready, still, but not unmoved; behind him is the coffin; but the eye gazes first and remains last on that pale, doomed face, beautiful and innocent, bewildered and calm. Let our readers take down Hume, and read the story. The cold and impassive philosopher writes as if his heart were full. Her husband, Lord Guildford, asked to see her before their deaths. She answered, No; that the tenderness of the parting would overcome the fortitude of both; besides, she said, their separation would be but for a moment. It had been intended to execute the Lady Jane and Lord Guildford together on the same scaffold on Tower Hill; but the Council, dreading the compassion of the people for their youth, beauty, innocence, and high birth, caused her to be beheaded within the verge of the Tower, after she had seen him from the window, and given him a token as he was led to execution. The conclusion by Hume is thus :- 'After uttering these words, she caused herself to be disrobed by her women, and with a steady, 
serene countenance submitted herself to the executioners.' The engraving, which may be seen at Mr. Hill's, is worthy of the picture and the subject. It is a marvel of delicate power, and is one of the very few modern engravings we would desire our friends to buy.

\section{NAPOLEON AT FONTAINEBLEAU BEFORE HIS ABDICATION.}

This is the first painting by Delaroche we have seen, though we have long been familiar with his works through their engravings. $\mathrm{He}$ is every inch a master. You get from his work that strange and delightful shock which asserts at once his genius and power. You are not struck, but you get a shock of surprise, of awe, and of pleasure, which no man who once gets ever mistakes for anything else. This picture, of

\section{' Him-}

Who in our wonder and astonishment

Has built himself a livelong monument,'

has this charm and power. You never before saw anything like it, you will never see anything like it again, and you will never forget it. It is no easy matter to describe what passes through one's mind on looking at such a bit of intense and deep genius. 


\section{Notes on Art.}

One feels more inclined in such a case to look, and recollect, to feel, and be grateful, than to speak.

Napoleon is represented as alone-seated hurriedly and sideways upon a chair-one leg of which has trod upon a magnificent curtain, and is trailing it down to ruin. He is dressed in his immortal grey coat, his leather breeches, and his big riding boots, soiled with travel; the shapely little feet, of which he was so proud, are drawn comfortlessly in; his hat is thrown on the ground. His attitude is that of the deepest dejection and abstraction; his body is sunk, and his head seems to bear it down, with its burden of trouble. This is finely indicated by the deep transverse fold of his waistcoat; one arm is across the back of the chair, the other on his knee, his plump hands lying idle; his hair, that thin, black straight hair, looks wet, and lies wildly across his immense forehead. But the face is where the artist has set his highest impress, and the eyes are the wonder of his face. The mouth is firm as ever-beautiful and unimpassioned as an infant's ; the cheeks plump, the features expressive of weariness, but not distressed; the brow looming out from the dark hair, like something oppressively and supernaturally capacious ; and then the eyes! his whole mind looking through them,-bodily distress, want of sleep, fear, doubt, shame, astonishment, anger, speculation, seeking rest but as yet finding it not; going over all possibilities, 
calm, confounded, but not confused. There is all this in the grey, serious, perplexed eyes; we don't know that we ever saw anything at once so subtle, awful, and touching, as their dreary look. Your eyes begin soon to move your heart; you pity and sympathize with him, and yet you know all he has done, the havoc he has made of everything man holds sacred, or God holds just; you know how merciless he was and will be, how eaten up with ambition, how mischievous; you know that after setting at defiance all mankind, and running riot in victory, he had two years before this set his face against the heavens, and, defying the elements, had found to his own, and to his country's tremendous cost, that none can 'stand before His cold.' We know that he is fresh from the terrible three days at Leipsic, where he never was so amazing in his resources, and all that constitutes military genius; we know that he has been driven from his place by the might and the wrath of the great German nation, and that he is as faithless and dangerous as ever; but we still feel for him. Our soul is 'purged by terror and pity,' which is the end of tragic art as well as of tragic writing, and will be found like it one of of the 'gravest, moralest, and most profitable' of all human works. This is the touch 'that makes the whole world kin.'

This trouble in the eye-this looking into vacancy, 


\section{Notes on Art.}

and yet not being vacant-this irresolute and helpless look in one so resolute, so self-sustained, is to us one of the very highest results of that art which affects the mind through the eye.

The picture, as a work of art, is remarkable for its simplicity of idea and treatment, the severity of its manner, and the gloomy awfulness everywhere breathing from it. It seems to gather darkness as you gaze at it; the imperial eagles emblazoned on the wall are struggling through a sort of ruddy darkness produced by the deep shadow on the richcoloured curtain. His sword is lying on a table, its hilt towards us.

But what impressed us most, and what still impresses us is, that we have seen the man as he then was, as he then was looking, and thinking, feeling, and suffering. We started at first as if we were before him, rather than he before us, and that we would not like to have that beautiful but dread countenance, and those unsearchable, penetrating cold eyes lifted up upon us.

No man need ask himself after this, if Delaroche is a great artist ; but some of his other works display, if not more intensity, more variety of idea and expression. Their prevailing spirit is that of severe - truthfulness, simplicity, and a kind of gloomy power - a certain awfulness, in its strict sense, not going up to sublimity perhaps, or forward into beauty. 
but lingering near them both. They are full of humanity, in its true sense; what he feels he feels deeply, and it asserts its energy in every bit of his handiwork.

It is remarkable how many of his best pictures are from English history, and how many are possessed by Englishmen. The following short sketch of his chief pictures may be interesting. His, earliest works were on religious subjects; they are now forgotten. The first which attracted attention was the picture of Joan of Arc in prison, examined by Cardinal Winchester; this has been engraved, and is very great-full of his peculiar gloom. Then followed Flora Macdonald succouring the Pretender; the death of Queen Elizabeth, almost too intense and painful for pleasurable regard; a scene at the Massacre of St. Bartholomew ; Death of the English Princes in the Tower; Richelieu on the Rhone, with Cinq Mars and De Thou as prisoners; Death of Cardinal Mazarin; Cromwell regarding the dead body of Charles I. This last is a truly great and impressive picture-we hardly know one more so, or more exactly suited for Art. The great Protector, with his well-known face, in which ugliness and affection and power keft such strange company, is by himself in a dark room. And yet not by himself. The coffin in which Charles, his king, is lying at rest, having ceased from troubling, is before him, and he has lifted up the lid and is gazing on the 
dead king-calm, with the paleness and dignity of death-of such a death, upon that fine face. You look into the face of the living man; you know what he is thinking of. Awe, regret, resolution. He knows the full extent of what has been done-of what he has done. He thinks, if the dead had not been false, anything else might have been forgiven; if he had but done this, and not done that; and his great human affections take their course, and he may wish it had been otherwise. But you know that having taken this gaze, and having let his mind go forth in its large issues, as was his way, he would again shut that lid, and shut his mind, and go away certain that it was right, that it was the only thing, and that he will abide by it to the end. It is no mean art that can put this into a few square inches of paper, or that can raise this out of any ordinary looker-on's brain. What a contrast to Napoleon's smooth, placid face and cold eyes, that rough visage, furrowed with sorrow and internal convulsions, and yet how much better, greater, worthier, the one than the other! We have often wondered, if they had met at Lützen, or at sorne of the wild work of that time, what they would have made of each other. We would lay the odds upon the Brewer's Son. The intellect might not be so immense, the seif-possession not so absolute, but the nature, the whole man, would be more powerful, because more in the right and 
more in sympathy with mankind. He would never try an impossible thing; he would seldom do a wrong thing, an outrage to human nature or its Author ; and for all that makes true greatness and true courage, we would not compare the one with the other. But to return to our artist. There is St. Amelia praying; very beautiful; Death of Duke of Guise at Blois; Charles I. in the Guard-room, mocked by the soldiers ; Lord Strafford going to execution, kneeling as he passes under the window of Laud's cell, whose outstretched hands bless him. This is a great picture; nothing is seen of Laud but the thin, passionate, imploring hands, and yet you know what they express, you know what sort of a face there will be in the darkness within. Strafford is very fine.

There is a charming portrait of his wife as the angel Gabriel ; a St. Cecilia playing; and a beautiful Holy Family, the Virgin, a portrait of his wife, and the child, a beautiful rosy creature, full of favour, with those deep, unfathomable, clear eyes, filled with infinity, such as you see in Raphael's Sistine Jesus.

\section{NAPOLEON CROSSING THE ALPS.}

Last year at this time we were all impressed, as we seldom are by anything of this sort, by Delaroche's picture of Napoleon at Fontainebleau. We are none of us likely to forget the feeling then experienced of 
being admitted into that dread presence, and looking, not only at the bodily form, but into the very soul of that great and miserable man. We may now get a different and yet a similar impression, from what we cannot but regard as a nobler and more touching work-something deeper and finer still. Those who knew what we thought of the first, will understand how much praise of the second is involved in our saying this. Last year we saw before us the spectacle of power, perhaps the most intense and enormous ever committed by the Divine Disposer to one of his creatures, in ruins, having all but played the game out. It was the setting sun of a day of astonishment, brightness, and tempest, lightning and thunder ; but the great orb was sinking in disastrous storm and gloom-going down never to rise again. In this new picture, we have the rising sun climbing up its young morning sky; the hours of glory, of havoc, and of shame, are before him, and us. The innocent brightness of his new-born day is not yet gone; it will soon go.

Nothing can be simpler, or more everyday-like, than the body of the picture. A steady, painstaking mule, with his shoulder to the steep, his head well down, his nostrils dilated, his eye full of stress and courage, his last hind leg straining forward himself and his burden, his shaggy legs clotted with the sweat-ice-drops, the weather-worn harness painted as 
like as it can look, his ruffled and heated hide, the leash of thongs, which, dangling, has often amused and tickled his old and hungry sides, swinging forward in the gusty wind-his whole heart and soul in his work: he is led by his old master, with his homely, hardy, and honest face, his sinewy alpenstock in his hand. Far back on the mule sits Napoleon, consulting his own ease alone, not sparing man or beast-he was not given to spare man or beast-his muscles relaxed, his lean shapely leg instinctively gripping the saddle, his small handsome foot resting idly in the stirrup, the old useless knotted bridle lying on the mule's neck, his grey coat buttoned high up, and blown forward by the wind, his right harıd in his inner coat, his slight graceful chest well up, and, above it, his face! and, above it, that well-known hat, firmly held by the prodigious head within, the powdery snow grizzling its rim. Ay, that face! look at it; let its vague, proud, melancholy gaze, not at you, or at anything, but into the immense future, take possession of your mind. He is turning the north side of the Alps; he is about descending into Italy; and what of that ?- we all know now what of that, and do not know yet all of it. We were then, such of us as may have been born, as unconscious of what was before us and him, as that patient mule or his simple master. Look at the face narrowly: it is thin; the cheeks sunken; the chin 
exquisite, with its sweet dimple; the mouth gentle, and firm, and sensitive, but still as death, not thinking of words or speech, but merely letting the difficult air of that Alpine region in and out. That same mouth which was to ignore the word impossible and call it a beast, and to know it, and be beaten by it in the end ; that thin, delicate, straight nose leading you to the eyes, with their pencilled and well-pronounced brows; there is the shadow of youth, and of indifferent health, under and around these eyes, giving to their power and meaning a singular charm - they are the wonder of the picture. He is looking seriously, but blankly, far on and up, seeing nothing outwardly, the mind's eye seeing-who can tell what? His cheek is pale with the longing of greatness. The young and mighty spirit within is awakening, and hardly knows itself and its visions, but it looks out clearly and firmly, though with a sort of vague sadness, into its appointed field.

Every one must be struck with this look of sorrow; a certain startled air of surprise, of hope, and of fear : his mind plays deeply with the future that is far off,-besides doing anything but play with his work to-morrow, that, as we shall soon hear, was earnest enough, as Marengo can tell. Such is the natural impression, such the feelings, this picture made and awakened in our minds through our eyes. It has a certain plain truth and immediateness of its own, which leads to 
the idia of all that followed; and, lest this effect be said to be ours, not the picture's, we would ask any man to try and bring such an idea, or indeed any idea, into the head of any one looking at David's absurd piece of horsemanship, called Crossing the Alps. And what is that idea? Everything ripening for that harvest, he is putting his sickle forth to reap. France, terrified and bleeding, and half free, getting sight of its future king-rousing itself and gathering itself up to act. Italy, Austria, and the drowsy, rotten, bewildered kingdoms, turning uneasily in their sleep, and awakening, some of them never again to rest; even the utmost north to bear witness of him, and take terrible vengeance for his wrongs. Egypt has already been filled with the glory, the execration, and disgrace of his namie; and that Holy Land, the theatre of the unspeakable wonders and goodness of the Prince of Peace, that too has seen him, and has cast him out, by the hearty courage and hatred of an English captain and his sailors. England also is to play a part ; to annihilate his fleets, beat him and his best marshals wherever she meets them, and finish him utterly at last.

And what changes - as strange, though more hidden-in character, in affection, in moral worth, are to take place in that beautiful and spiritual countenance, in that soul of which it is the image; infinite pride, and glory, and guilt, working their fell will 
upon him-his being (that most dreadful of all calamities to a creature like man) left altogether to himself. How the wild, fierce courage of Lodi and Arcola is to waste away into the amazing meanness of 'Sauve qui peut' - the Regent's letter, and the pitiful bullying on board the Bellerophon. Before him lie his victories, his mighty civil plans, his code of laws, his endless activity, his prodigious aims, even his medals so beautiful, so ridiculous, so full of lies -one of them telling its own shame, having on one side Hercules strangling the monster of the sea (England), and on the other the words 'Struck at London!!' his perfidy and cruelty; the murdered young D'Enghien; the poisoned soldiers at Jaffa. The red field of Leipsic rises stark on our sight, where the great German people, that honest and right-hearted but slow race, fell and rose again, never again to fall so low, and, by and by, through the same vital energy, it may be soon, to rise higher than many think, when, rousing themselves like a strong man after sleep, they shall drive their enemies, be they kings or priests, as old Hermann and his Teuts chased the Roman Eagles across the Rhine, and returning, lift up like them their beer horns in peace; this has always seemed to us the great moral lesson. to the world of Napoleon's career. But our readers are impatient; they have, perhaps, parted company with us long ago. One thing they will agree with us 
in, that this picture raises up the mind of the looker; fills his memory with living forms; breathes the breath of life and of human nature into the eventful past, and projects the mind forward upon the still greater future; deepens impressions, and writes 'Vanity of vanity, all is vanity,' on such mad ambition-.

' The glories of our earthly state

Are shadows, not substantial things.'

But to return to our picture. Behind Napoleon is another guide, leading the horse of a soldier, muffled up, and battling with the keen mountain wind. This closes the scene; around and above are the everlasting Alps, looking as they did when Hannibal passed nearly 3000 years before, and as they will do thousands of years hence. They bear down upon the eye in a formidable way, as if frowning at the intruder on their snows and silence, and as if crowding down to withstand his steps. Under is the spotless snow, with some bits of ice, troubling the hoofs of the mule. This completes the picture, which, as we have already said, is homely and simple in its body, in all that first meets the eye, though informed throughout with the finest phantasy when the mind rests upon it and reaches its soul.

Every one must be struck with the personal beauty of Napoleon as represented here. $\mathrm{He}$ was in his 3 Ist year; had been four years married to Josephine 


\section{Notes on Art.}

-the happiest years of his life; he had just come from Egypt, having been hunted across the Mediterranean by Nelson. His peasant guide, who succeeded to the old man, and who brought him within sight of Italy, described him as "a very dark man, and with an eye which, though affable, he did not like to encounter.' We can believe him; a single look of that eye, or a word from that mouth, cheered and set in motion the wearied army as they toiled up ' the Valley of Desolation;' and if they stuck fast in despair, the Consul had the drums beat, and trumpets sounded, as for the charge. This never failed. He knew his men.

This picture was conceived by Delaroche last year, on the spot where the scene is laid, and painted very soon after. He was at Nice for his health, and had for his guide up the St. Bernard, the son of the man leading the mule, who told him many things about Napoleon, and how he looked. As regards colour, it is the best of Delaroche's pictures we have seen ; it is a curious study to mark how little, and how much, the young, thin, spiritual face differs from that of last year's picture.

There is something to our minds, not unseasonable in directing our thoughts to such a spectacle of mere human greatness, at this (Christmas) sacred time. So much mischief, crime, and misery, and yet so much power, intelligence, progress, and a certain 
dreadful usefulness in the career of such a man. What a contrast to His life, who entered our world I $85^{\circ}$ years ago, and whose birth was heralded by the angel-song, 'Glory to God in the highest, and 'on earth peace, goodwill toward men ;' whose religion and example, and continual living influence, has kept this strange world of ours from being tenfold more wicked and miserable than it is. We would conclude with the words of the poet of $I n$ Memoriam -

'Ring out the old, ring in the new,

Ring happy bells across the snow,

The year is going, let him go ;

Ring out the false, ring in the true.

'Ring out a slowly dying cause,

And ancient forms of party strife;

Ring in the nobler forms of life,

With sweeter manners, purer laws

'Ring out false pride in place and blood,

The civic slander and the spite;

Ring in the love of truth and right,

Ring in the common love of good.

'Ring out old shapes of foul disease,

Ring out the narrowing lust of gold;

Ring out the thousand wars of old, Ring in the thousand years of peace.'

\section{THE LIGHT OF THE WORID.}

If this picture in any degree fulfil its object, if we are impressed and moved by it, then it is not 
matter for words, it partakes of the unspeakableness of its subject. If it fall short of this, it fails utterly, and is not worth any words but those of displeasure, for nothing is more worthless, nothing is more truly profane, and few things are more common, than the attempt to represent sacred ideas by a man who is himself profane, and incapable of impressing others. For it is as unseemly, and in the true sense as profane, for a painter to paint such subjects if he do not feel them, as it is for a man to preach the great truths of our most holy faith, being himself an unbeliever, or at the best a Gallio, in both cases working merely for effect, or to bring in wages.

This picture is not liable to any such rebuke. Whatever may be thought of its central idea and of its expression, no one can doubt-no one can escape coming under-its power, its true sacredness. Watch the people studying it; listen, not to their words, but to their silence; they are all as if performing an act of worship, or at least of devout reverence. The meaning of the picture reaches you at once: that lonely, serious, sorrowful, majestic countenance and form; those wonderful listening eyes, so full of concern, of compassion-'acquainted with grief;' the attitude of anxious hearkening, as if 'waiting to be gracious.' This idea rules the whole. We all feel who $\mathrm{He}$ is, and what $\mathrm{He}$ is 
desiring; and we feel, perhaps it may be in a way never felt before, the divine depth of the words, 'Behold, I stand at the door and knock; if any man open unto me, I will come in to him, and sup with him, and he with me;' and we see that though $\mathrm{He}$ is a king, and is 'travelling in the greatness of his strength, mighty to save,' He cannot open the door-it must open from within- $\mathrm{He}$ can only stand and knock.

We confess that, with this thought filling our mind, we care little for the beautiful and ingenious symbols with which the painter has enriched his work; that garden run wild, that Paradise Lost, with the cold starlight indicating and concealing its ruin-all things waste; the light from the lantern falling on the apple (a wonderful bit of painting) 'the fruit of that forbidden tree;' the darnel or tares choking up the door, and the gentle but inveterate ivy grasping it to the lintel; the Jewish and the Gentile emblems clasped together across his breast; the crown, at once royal and of thorns, set with blood-red carbuncles; and many other emblems full of subtle spiritual meaning. We confess to rather wishing the first impression had been left alone.

The faults of the picture as a work of art are, like its virtues, those of its school-imitation is sometimes mistaken for representation. There is a 
want of the unity, breadth, and spaciousness of nature about the landscape, as if the painter had looked with one eye shut, and thus lost the stereoscopic effect of reality-the solidarity of binocular vision; this gives a displeasing flatness. It is too full of astonishing bits, as if it had been looked at, as well as painted, piece-meal. With regard to the face of our Saviour, this is hardly a subject for criticism,- - as we have said, it is full of majesty and tenderness and meaning; but we have never yet seen any image of that face so expressive as not to make us wish that it had been left alone to the heart and imagination of each for himself. In the 'Entombment,' by Titian, one of the three or four greatest pictures in the world, the face of the dead Saviour is in shadow, as if the painter preferred leaving it thus, to making it more definite; as if he relied on the idea-on the spiritual image-rising up of itself; as if he dared not be definite; thus showing at once his greatness and modesty by acknowledging that there is 'that within which passeth show.'

\section{R I Z P A H.}

Take one of Turner's sketches in his Liber Studiorum, a book which, for truth and power, and the 
very highest imaginative wis, must be compared, not with any other book of prints, but with such wordpictures as you find in Dante, in Cowper, in Wordsworth, or in Milton. It is a dark foreground filled with gloom, savage and wild in its structure; a few grim heavy trees deepen the gloom: in the centre, and going out into the illimitable sky, is a brief, irregular bit of the purest radiance, luminous, but far off. There is a strange meaning about the place; it is 'not uninformed with phantasy, and looks that threaten the profane.' You look more keenly into it. In the centre of the foreground sits a woman, her face hidden, her whole form settled down as by some deep sorrow; she holds up, but with her face averted, a flaming torch; behind, and around her, lie stretched out seven bodies as of men, half-naked, and dimly indicating far-gone decay: at their feet are what seem like crowns. There is a lion seen with extended tail slinking off, and a bittern has just sprung up in the corner from a reedy pool. The waning moon is lying as if fainting in the grey heavens. The harvest sheaves stand near at hand, against the sky. The picture deepens in its gloom. The torch gives more of its fitful light as you steadily gaze. What is all this? These are two sons and five grandsons of Saul, who 'fell all seven together, and were put to death in the days of harvest, in the beginning of barley harvest.' And she who sits 
there solitary is 'Rizpah, the daughter of Aiah, who took sackcloth, and spread it for her upon the rock, from the beginning of harvest until water dropped upon them out of heaven, and suffered neither the birds of the air to rest on them by day, nor the beasts of the field by night.' For five months did this desolate mother watch by the bodies of her sons! She is at her ceaseless work, morn, noon, and night incessantly. How your heart now fills, as well as your eyes! How you realize the idea! What a sacred significance it gives to the place, and receives from it! What thoughts it awakens! Saul and his miserable story, David and his lamentation, the mountains- of Gilboa, the streets of Askelon. The king of beasts slinking off once more, hungry, angry, and afraid - finding her still there. The barley sheaves, indicating by a touch of wonderful genius, that it is nearer the beginning than the end of her time, so that we project our sympathy forward upon the future months. No one but a great artist would have thought of this. And that unfailing, forlorn woman, what love! That only love which He whose name and nature it has honoured by admitting to be nearest, though at an infinite distance from His own. 'Can a woman forget? - Yea, she may forget.' Here we have a scene in itself impressive, and truthfully rendered, enriched, and sanctified by a subject of the 
highest dignity, and deepest tenderness, and in perfect harmony with it.

Many may say we bring out much that is not in it. This may be partly true, and is rather to that extent an enhancement of its worth. But the real truth is, that there is all this in it, if it be but sought for and received in simplicity and reverence. The materials for imagination are there; let the spectator apprehend them in the like spirit, and he will feel all, and more than we have described. Let a man try to bring anything out of some of the many landscapes we see in our Exhibitions, and he may be strong and willing, but it will prove too hard for him; it is true here as everywhere else - ex nithilo nihil fit - ex pario, parvum-ex falso, falsum - ex magno, magnum - ex Deo, Optimo, Maximo, maximum, optimum, divinum.

\section{THE GLEN OF THE ENTERKIN.}

This is a representation by Mr. Harvey of a deep, upland valley; its truthfulness is so absolute, that the geologist could tell from it what formation was under that grass. The store-farmer could say how many sheep it could feed, and what breed those are which are busy nibbling on that sunny slope. The botanist could tell not only that that is a fern, but that it is the Aspidium filix-mas; and the naturalist 


\section{Notes on Art.}

knows that that water-wagtail on that stone is the Motacilla Yarrelli. To all this, the painter has added his own thoughts and feelings when he saw and when he painted this consummate picture. It is his idea of the place, and, like all realized ideals, it has first crept into his study of imagination, before it comes into the eye and prospect of his soul or of ours. We feel the spirit of the place, its gentleness, its unspeakable seclusion. The one shepherd with his dog far up on the hillside, grey and steadfast as any stone, adding the element of human solitude, which intensifies the rest. It were worth one's while to go alone to that glen to feel its beauty, and to know something of what is meant by the 'sleep that is among the lonely hills,' and to feel, moreover, how much more beautiful, how much more full of life the picture is than the reality, unless indeed we have the seeing eye, the understanding heart, and then we may make a picture to ourselves.

\section{DAWN-LUTHER IN THE CONVENT LIBRARY AT ERFURT.}

This is, we think, Mr. Paton's best work. We do not say his greatest, for that may be held to include quantity of genius as well as quality. He has done other things as full of imagination, and more 
full of fancy; but there is a seriousness and depth, a moral and spiritual meaning and worth about this which he has never before shown, and which fully deserve the word best.

The picture requires no explanation. It is Luther, the young monk of four-and-twenty, in the Library of the Convent of Erfurt. He is at his desk, leaning almost wildly forward, one knee on the seat-its foot has dropped the rude and worn sandal--the other foot on the floor, as it were pressing him forward. He is gazing into the open pages of a huge Vulgate -we see it is the early chapters of the Romans. A bit of broken chain indicates that the Bible was once chained-to be read, but not possessed-it is now free, and his own. His right hand is eagerly, passionately drawing the volume close to him. His face is emaciated to painfulness; you see the traces of a sleepless night - the mind sleepless, and worse, seeking rest, and as yet finding none, but about to find it-and this takes away from what might otherwise be a plus of pain. Next moment he will come upon-or it on him - the light from heaven, shining out from the words, 'Therefore being justified by faith, we have peace with God ;' and in intimation of this, His dawn, the sweet, pearly light of morning, shining in at the now open lattice, is reflected from the page upon his keen anxious face-'faint yet pursuing.' If you look steadily into that face, you 
will see that the bones of the mighty Reformer's face, so well known to us, are all there, and need but good food and sleep, and the open air, and peace of mind, and the joy of victorious faith and work, to fill it up and make it plump, giving it that look of energy in repose, of enough and to spare, of masculine power, which that broad, massive, but soft and kindly visage, wears written all over it ; and the slightly upturned head, the clear, open, deep eyes, and that rich chin and neck, 'dewlapped like a 'Thessalian bull.'

And we know that all this misery, and exanimation, and wasting are true. We know that when his friend Alexis was struck down dead by lightning at his side as they walked together, he also was struck down in his mind; and in the words of Principal Tulloch in his admirable sketch, he carried out his resolve in a way curiously and entirely his own'One evening he invites some of his fellow-students to supper, gives them of his best cheer, music and jest enliven the company, and the entertainment closes with a burst of merriment. The same night there is a solitary knock at the door of the Augustinian Convent, and two volumes alone of all his books in his hand-Plautus and Virgil-Luther passes under its portal.' Three long, dreary years he has been there, doing all sorts of servile worksweeping the floors, begging in the streets with his 
wallet-'Saccum per nackum'-for food and dainties to his lazy brethren. Sometimes four days without meat or drink-hiding himself for a week with his books in his cell, where, when broken in upon, he is found lying cold and senseless on the floor; and all this bodily wretchedness, struggle, and unrest but a material type of the mental agony within trying to work out his own salvation with all sorts of 'fear and trembling.' And now the natural dawn has found him still at his book, and is pouring its 'innocent brightness' everywhere, and its fresh airs are stirring the white blossoms of the convolvulus outside, and making them flutter and look in like doves-the dew of their youth and of the morning glistering, if looked for. And this time it has found him with his morn beginning too - the clear shining after the rain, the night far past, the day at hand; he has 'cast off the works of darkness, and put on the armour of light.' 'The Sun of Righteousness is about to arise upon him. Henceforth you know well what he is to become and do-a child of the light, he walks abroad like one, and at liberty he goes forth upon his work, rejoicing like a strong man to run his race. That great human spirit finds rest and a resting-placehas got that fulcrum on which, with his strong heart and his lever, he is to move a world. That warm, urgent, tender, impetuous human heart is to be satisfied with the fellowship of his kind, and with the love 


\section{Notes on Art.}

of his Catherine- 'his heart-loved housewife and sow-marketress, and whatever more she may be'and to run over in babble (as who ever else did?) to his 'Johnny,' his 'Philip and his Joe,' or overflow with tears as he looks on his 'darling Lena' in her coffin, saying, 'How strange it is to know so surely that she is at peace and happy, and yet for me to be so sad.'

And now that this dominant, central idea-which is the heart and soul, the motive power of the piece -is taken in and moves you, examine the rest-the great Vulgate and St. Augustine De Civitate Dei, and Thomas Aquinas, and the other old fellows, old and strong, lying all about, as if taken up and thrown down in restless search, how wonderfully they are painted! or rather, how wonderfully you never think of them as painted! and yet they are not merely imitated-you don't mistake them for actual books, they are the realized ideas of books. And that sacred, unspeakable scene, dim, yet unmistakable, looking out upon you from the back of his desk-the Agony of the Garden-carved and partly coloured and gilt ; look at it - that is religious painting. Our Saviour on his knees 'praying more earnestly' - the sleepers lying around-the mystic, heavy, sombre olive-trees, shutting out the light of heaven, and letting the lanterns of those 'with swords and staves' gleam among their stems; him who was a thief, 
crouching, stealing on with his bag and his crew, and the curse heavy upon him-all this is in it, and all subordinate, and yet done to the quick, as if a young Albert Durer or Van Eyck had had his knife in the wood, and his soul at his knife. Then, on the plastered wall behind the young monk is an oval portrait of Alexander the Sixth, the tremendous Borgia, that prodigy of crime and power-his face, what a contrast to the wasted boy's beneath! he is fat and flourishing, rosy and full of blood and of the pride of life, insolent and at his ease; Luther like a young branch all but withered in the leaves of his spring - the Vicar of God spreading like a green bay tree. He is holding up his two first fingers in the Apostolic benediction, with a something between a scowl and a leer-all this rendered, and yet nothing overdone. This portrait hangs on a rude drawing of the Crucifixion, as if by a young and adoring hand, full of feeling and with a touching uncertainty in the lines, as if the hand that traced it was unaccustomed and trembling; it conceals our Saviour's face. As we have said, the lattice has been opened, and the breath of the morning is flowing into the dark, stifling room. The night lamp has gone out, paling its ineffectual fires, and its reek is curling up and down, and away. This, as a piece of handiwork, is wonderful. When you look narrowly into the picture, you see a chrysalis in the gloom, just opening its case, ready when struck 
by the light and heat to expand and fly. The sunlight throws across towards Borgia the rich blooms of the stained glass, the light made gloriously false in passing through its disturbing medium; while the pure, white light of heaven passes straight down upon the Word of God, and shines up into the face of the young reader.

Such is a mere notion of this excellent picture; it is painted throughout with amazing precision, delicacy, sweetness, and strength, in perfect diapason from first to last, everything subordinate to the one master note. Every one will be surprised, and some may be shocked, at the face, and hands, and look of Luther, but let them remember where he is, and what he has been and is doing and suffering. This amount of pain gives a strange and true relish, if it is taken up and overpowered and transfigured into its opposite by our knowledge that it was to be 'but for a moment,' and then the 'far more exceeding' victory and joy.

\section{BEAUTY, ABSOLUTE AND RELATIVE.}

We are not now going to try our 'prentice hand upon a new theory of Beauty, after so many masters have failed; but we cannot help thinking that the dispute would be at an end if it were but allowed at once, that there are two kinds of beauty, that there 
is a material and necessary element of beauty, and another which is contingent and relative-a natural and a spiritual delightfulness to and through the eye; and that sometimes we see both together, as in the face and eyes of a beautiful and beloved woman; and moreover, that there is no more reason for denying either the sense or the emotion of beauty, because everybody does not agree about the kind or measure of either of these qualities in all objects, than there is for affirming that there is no such thing as veracity or natural affection, because the Spartans commended lying, and the Cretians practised it, or the New Zealanders the eating of one's grandmother. Why should the eye, the noblest, the amplest, the most informing of all our senses, be deprived of its own special delight? The light is sweet, and it is a pleasant thing for the eye to behold the sun; and why, when the ear has sound for informing, and music for delight-when there is smell and odour, taste and flavour, and even the touch has its sense of pleasant smoothness and softness-why should there not be in the eye a pleasure born and dying with the sights it sees? it is like the infinite loving-kindness of Him who made the trees of the garden pleasant to the eye as well as good for food. We say nothing here of Relative or Associative Beauty,- - this has never been doubted either in its essence or its value. It is as much larger in its range, as much nobler in its mean- 
ing and uses, as the heavens are higher than the earth, or as the soul transcends the body. This, too, gives back to material beauty more than it received : it was after man was made, that God saw, and, behold, everything was very good.

Our readers may perhaps think we make too much of imagination as an essential element-as the essential element-in Art. With our views of its function and its pervading influence in all the ideal arts, we can give it no other place. A man can no more be a poet or painter in the spiritual and only true sense without imagination, than an animal can be a bird without wings ; and as, other things being equal, that bird can be longest on the wing and has the greatest range of flight which has the strongest pinions, so that painter is likely to have the farthest and keenest vision of all that is within the scope of his art, and the surest and most ample faculty of making known to others what he himself has seen, whose imagination is at once the most strong and quick. At the same time, if it be true that the body without the spirit is dead, so it is equally true that the spirit without the body is vain, ineffectual, fruitless. Imagination alone can no more make a painter or a poet than wings can constitute a bird. Each must have a body. Unfortunately, in painting we have more than enough of body without spirit. Correct drawing, wonderful imitative powers, cleverness, adaptiveness, 
great facility and dexterity of hand, much largeness of quotation, and many material and mechanical qualities, all go to form an amusing, and, it may be, useful spectacle, but not a true picture. We have also, but not so often, the reverse of all this, - the vision without the faculty, the soul without the body, great thoughts without the power to embody them in intelligible forms. $\mathrm{He}$, and he alone, is a great painter, and an heir of time, who combines both. He must have observation,--humble, loving, unerring, unwearied; this is the material out of which a painter, like a poet, feeds his genius, and 'makes grow his wings.' There must be perception and conception, both vigorous, quick, and true: you must have these two primary qualities, the one first, the other last, in every great painter. Give him good sense and a good memory, it will be all the better for him and for us. As for principles of drawing and perspective, they are not essential. A man who paints according to a principle is sure to paint ill; he may apply his principles after his work is done, if he has a philosophic as well as an ideal turn. 


\section{'OH, I'M WAT, WA'T.'}

The father of the Rev. Mr. Steven of Largs, was the son of a farmer, who lived next farm to Mossgiel. When a boy of eight, he found 'Robbie,' who was a great friend of his, and of all the children, engaged digging a large trench in a field, Gilbert, his brother, with him. The boy pausing on the edge of the trinch, and looking down upon Burns, said, 'Robbie, what's that ye're doin'?' 'Howkin' a muckle hole, Tammie.' 'What for?' 'To bury the Deil in, Tammie!' (one can fancy how those eyes would glow.) 'A' but, Robbie,' said the logical Tammie, 'hoo' re ye to get him in?' 'Ay,' said Burns, 'that's it, hoo are we to get him in!' and went off into shouts of laughter; and every now and then during that summer day shouts would come from that hole, as the idea came over him. If one could only have daguerreotyped his day's fancies! 



\section{'OH, I’M WAT, WA T.'}

WHAT is love, Mary?' said Seventeen to Thirteen, who was busy with her English lessons.

'Love! what do you mean, John?'

'I mean, what's love?'

'Love's just love, I suppose.'

(Yes, Mary, you are right to keep the concrete; analysis kills love as well as other things. I once asked a useful-information young lady what her mother was. 'Oh, mamma's a biped!' I turned in dismay to her younger sister, and said, 'What do you say?' 'Oh, my mother's just my mother.')

'But what part of speech is it?'

'It's a substantive or a verb.' (Young Horne Tooke didn't ask her if it was an active or passive, an irregular or defective verb; an inceptive, as calesco, I grow warm, or dulcesco, I grow sweet; a frequentative or a desiderative, as mupturio, I desire to marry.)

'I think it is a verb,' said John, who was deep in 
other diversions besides those of Purley; 'and I think it must have been originally the Perfect of Live, like thrive throve, strive strove.'

' Capital, John!' suddenly growled Uncle Oldbuck, who was supposed to be asleep in his armchair by the fireside, and who snubbed and supported the entire household. 'It was that originally, and it will be our own faults, children, if it is not that at last, as well as, ay, and more than at first. What does Richardson say, John? read him out.' John reads--

$\begin{array}{ll}\text { LOVE, } v . s . & \text { To prefer, to desire, as an } \\ \text {-LESS. } & \text { object of possession or enjoy- } \\ \text {-LY, ad. av. } & \text { ment ; to delight in, to be } \\ \text {-LILY. } & \text { pleased or gratified with, to } \\ \text {-LINESS. } & \text { take pleasure or gratification } \\ \text {-ER. } & \text { in, delight in. } \\ \text {-ING. } & \text { Love, the } s \text {. is app. emph. to } \\ \text {-INGLY. } & \text { the passion between the sexes. } \\ \text {-INGNESS. } & \text { Lover is, by old writers, app. as } \\ \text {-ABLE.* } & \text { friend -by male to male. } \\ \text {-SONE. } \dagger & \text { Love is much used-pref. } \\ \text { ERED. } \ddagger & \text { * Wiclif. } \dagger \text { Chaucer. } \ddagger \text { Shak. }\end{array}$

Love-locks,-locks (of hair) to set off the beauty ; the loveliness.

A.S. Luf-ian; D. Lie-ven; Ger. -ben, amare, diligere. Wach. derives from lieb, bonum, because every one desires that which is good; lieb, it is more probable, is from lieb-en, grateful, and therefore good. It may at least admit a conjecture that A. S. Lufian, to love, has a reason for its application similar to that of $\mathrm{L}$. Di-ligere (legere, to gather), to take up or out (of a number), to choose, sc. one in preference to another, to prefer: and that it is formed upon A. S. Hlif-ian, to lift or take up, to pick up, to select, to prefer. Be-Over- Un- 
Uncle impatiently._-Stuff ; "grateful!" "pick up!" stuff! These word-mongers know nothing about it. Live, love ; that is it, the perfect of live.' 1

After this, Uncle sent the cousins to their beds. John's mother was in hers, never to rise from it again. She was a widow, and Mary was her husband's niece. The house quiet, Uncle sat down in his chair, put his feet on the fender, and watched the dying fire ; it had a rich central glow, but no flame, and no smoke, it was flashing up fitfully, and bit by bit falling in. He fell asleep watching it, and when he slept, he dreamed. He was young; he was seventeen, he was prowling about the head of North St. David Street, keeping his eye on a certain door,-we call them common stairs in Scotland. He was waiting for Mr. White's famous English class for girls coming out. Presently out rushed four or five girls, wild and laughing; then came one, bounding like a roe:

'Such eyes were in her head, And so much grace and power!'

She was surrounded by the rest, and away they went laughing, she making them always laugh the more.

1 They are strange beings, these lexicographers. Richardson, for instance, under the word SNAIL, gives this quotation from Beaumont and Fletcher's Wit at Several Weapons,

'Oh, Master Pompey! how is't, man?

Clonun-SNaILS, I'm almost starved with love and cold, and one thing or other.'

Any one else knows of course that it is 's nails'-the contraction of the old oath or interjection-God's nails. 
Seventeen followed at a safe distance, studying her small, firm, downright heel. The girls dropped off one by one, and she was away home by herself, swift and reserved. He, impostor as he was, disappeared through Jamaica Street, to reappear and meet her, walking as if on urgent business, and getting a cordial and careless nod. This beautiful girl of thirteen was afterwards the mother of our Mary, and died in giving her birth. She was Uncle Oldbuck's first and only sweetheart; and here was he, the only help our young Horne Tooke, and his mother and Mary had. Uncle awoke, the fire dead, and the room cold. $\mathrm{He}$ found himself repeating Lady John Scott's lines-.

'When thou art near me,

Sorrow seems to fly, And then I think, as well I may, That on this earth there is no one

More blest than I.

But when thou leav'st me,

Doubts and fears arise, And darkness reigns,

Where all before was light.

The sunshine of my soul

Is in those eyes,

And when they leave me

All the world is night.

But when thou art near me,

Sorrow seems to fly, And then I feel, as well I may, That on this earth there dwells not one

So blest as I.' 1

1 Can the gifted author of these lines and of their music not be prevailed on to give them and others to the world, as well as to her friends? 
Then taking down Chambers's Scottish Songs, he read aloud :-

'O, I'm wat, wat,

$\mathrm{O}$, I'm wat and weary ;

Yet fain wad I rise and rin,

If I thocht I would meet my dearie.

Aye waukin', O !

Waukin' aye, and weary ;

Sleep I can get nane

For thinkin' o' my dearie.

Simmer's a pleasant time,

Flowers o' every colour ;

The water rins ower the heugh,

And I long for my true lover.

When I sleep I dream,

When I wauk I'm eerie,

Sleep I can get nane,

For thinkin' o' my deerie.

Lanely nicht comes on,

A' the lave are sleepin' ;

I think on my true love,

And blear my een wi' greetin .

Feather beds are saft-

Pentit rooms are bonnie;

But ae kiss o' my dear love

Better's far than ony.

O for Friday nicht !

Friday at the gloamin';

O for Friday nicht-

Friday's lang o' comin' !'

This love-song, which Mr. Chambers gives from recitation, is, thinks Uncle to himself, all but perfect; Burns, who in almost every instance, not only 
adorned, but transformed and purified whatever of the old he touched, breathing into it his own tenderness and strength, fails here, as may be seen in reading his version :-

'Oh, spring 's a pleasant time!

Flowers o' every colour-

The sweet bird build's her nest,

And I lang for my lover.

Aye wakin', oh!

Wakin' aye and wearie;

Sleep I can get nane,

For thinkin' o' my dearie!

'When I sleep I dream,

When I wauk I'm eerie,

Rest I canna get,

For thinkin' o' my dearie.

Aye wakin', oh!

Wakin' aye and weary,

Come, come, blissful dream,

Bring me to my dearie.

'Darksome nicht comes doun-

A' the lave are sleepin';

I think on my kind lad,

And blin' my een wi' greetin'.

Aye wakin', oh!

Wakin' aye and weary;

Hope is sweet, but ne'er

Sae sweet as my dearie!'

How weak these italics! No one can doubt which of these is the better. The old song is perfect in the procession, and in the simple beauty of its thoughts and words. A ploughman or shepherdfor I hold that it is a man's song-comes in 'wat, 


\section{'Oh, I'm Wat, Wat.'}

wat' after a hard day's work among the furrows or on the hill. The watness of wat, wat, is as much wetter than wet as a Scotch mist is more of a mist than an. English one ; and he is not only wat, wat, but 'weary,' longing for a dry skin and a warm bed and rest; but no sooner said and felt, than, by the law of contrast, he thinks on 'Mysie' or 'Ailie,' his Genevieve; and then 'all thoughts, all passions, all delights' begin to stir him, and 'fain wad I rise and rin' (what a swiftness beyond run is 'rin'!) Love now makes him a poet; the true imaginative power enters and takes possession of him. By this time his clothes are off, and he is snug in bed; not a wink can he sleep; that 'fain' is domineering over him,- - and he breaks out into what is as genuine passion and poetry, as anything from Sappho to Tennyson-abrupt, vivid, heedless of syntax. 'Simmer's a pleasant time.' Would any of our greatest geniuses, being limited to one word, have done better than take 'pleasant?' and then the fine vagueness of 'time!' 'Flowers o' every colour ;' he gets a glimpse of 'herself a fairer flower,' and is off in pursuit. 'The water rins ower the heugh' (a steep precipice); flinging itself wildly, passionately over, and so do I long for my true lover. Nothing can be simpler and finer than

' When I sleep, I dream;

When I wauk, I'm eerie.' 
'Lanely nicht;' how much richer and more touching than 'darksome.' 'Feather beds are saft;' 'pentit rooms are bonnie ;' I would infer from this, that his 'dearie,' his 'true love,' was a lass up at 'the big house' - a dapper Abigail possibly - at Sir William's at the Castle, and then we have the final paroxysm upon Friday nicht-Friday at the gloamin'! O for Friday nicht!-Friday's lang o' comin' !-it being very likely Thursday before day-break when this affectionate ululatus ended in repose.

Now, is not this rude ditty, made very likely by some clumsy, big-headed Galloway herd, full of the real stuff of love? He does not go off upon her eye-brows, or even her eyes; he does not sit down, and in a genteel way announce that 'love in thine eyes for ever sits,' etc. etc., or that her feet look out from under her petticoats like little mice: he is far past that; he is not making love, he is in it. This is one and a chief charm of Burns' love-songs, which are certainly of all love-songs except those wild snatches left to us by her who flung herself from the Leucadian rock, the most in earnest, the tenderest, the 'most moving delicate and full of life.' Burns makes you feel the reality and the depth, the truth of his passion : it is not her eyelashes, or her nose, or her dimple, or even

'A mole cinque-spotted, like the crimson drops

I' the bottom of a cowslip,' 


\section{'Oh, I'm Wat, Wat.'}

that are 'winging the fervour of his love ;' not even her soul; it is herself. This concentration and earnestness, this perfervor of our Scottish love poetry, seems to me to contrast curiously with the light, trifling, philandering of the English; indeed, as far as I remember, we have almost no lovesongs in English, of the same class as this one, or those of Burns. They are mostly either of the genteel, or of the nautical (some of these capital), or of the comic school. Do you know the most perfect, the finest love-song in our or in any language; the love being affectionate more than passionate, love in possession not in pursuit?

' Oh, wert thou in the cauld blast

On yonder lea, on yonder lea, My plaidie to the angry airt, I'd shelter thee, I'd shelter thee :

Or did Misfortune's bitter storms

Around thee blaw, around thee blaw, Thy bield should be my bosom,

To share it a', to share it a'.

' Or were I in the wildest waste,

Sae black and bare, sae black and bare,

The desert were a paradise,

If thou wert there, if thou wert there:

Or were I monarch o' the globe,

Wi' thee to reign, wi' thee to reign,

The brightest jewel in my crown

Wad be my queen, wad be my queen.'

The following is Mr. Chambers's account of the origin of this song :- Jessy Lewars had a call one 
morning from Burns. He offered, if she would play him any tune of which she was fond, and for which she desired new verses, that he would do his best to gratify her wish. She sat down at the piano, and played over and over the air of an old song, beginning with the words-

'The robin cam' to the wren's nest,

And keekit in, and keekit in :

"O wae's me on your auld pow!

Wad ye be in, wad ye be in?

Ye'se ne'er get leave to lie without,

And I within, and I within, As lang's I hae an auld clout,

To row ye in, to row ye in.",

Uncle now took his candle, and slunk off to bed, slipping up noiselessly that he might not disturb the thin sleep of the sufferer, saying in to himself- ' I'd shelter thee, I'd shelter thee ;' 'If thou wert there, if thou wert there ;' and though the morning was at the window, he was up by eight, making breakfast for John and Mary. 


\section{EDUCATION THROUGH THE SENSES.}

'Now, in matter of the knowledge of the works of nature, I would have you to study that exactly; that so there be no sea, river, nor fountain, of which thou dost not know the fishes; all the fowls of the air; all the several kinds of shrubs and tree, whether in forest or orchard; all the sorts of herbs and flowers that grow upon the ground; all the various metals that are hid within the bowels of the earth. Let nothing of all these be hadden from thee. . . . But because, as the wise man Solomon saith, wisdom entereth not into a malicious mind, and that knowledge without conscience is but the ruin of the soul; it behoveth thee to serve, to love, to fear God, and on him to cast all thy thoughts and all thy hope, and, by faith formed in love to cleave unto him, so that thou mayest never be separated from him by thy sins.'Letter from Garagantua to his son Pantagruet.

- Qui curiosus postulat totum suce Patere menti, ferre qui non sufficit

Mediocritatis conscientiam sua, Fudex iniquns, astimator est malus Suique naturaque; nam rerum parens, Libanda tantum qua venit mortalibus, Nos scire pauca, multa mirari jubet.'

'_- Quiescet animus, errabit minus Contentus eruditione parabili, Nec quaret illam, siqua quarentem fugit. Nescire quedam magna pars sapientice est.'

Grotius. 



\section{EDUCATION THROUGH THE SENSES.}

(REPRINTED FROM “THE MUSEUM.")

II

ONE of the chief sins of our time is hurry : it is helter-skelter, and devil take the hindmost. Off we go all too swift at starting, and we neither run so fast nor so far as we would have done, had we taken it cannily at first. This is true of a boy as well as of a blood colt. Not only are boys and colts made to do the work and the running of fullgrown men and horses, but they are hurried out of themselves and their now, and pushed into the middle of next week where nobody is wanting them, and beyond which they frequently never get.

The main duty of those who care for the young is to secure their wholesome, their entire growth, for health is just the development of the whole nature in its due sequences and proportions : first the blade - then the ear-then, and not till then, the full corn 
in the ear; and thus, as Dr. Temple wisely says, 'not to forget wisdom in teaching knowledge.' If the blade be forced, and usurp the capital it inherits; if it be robbed by you its guardian of its birthright, or squandered like a spendthrift, then there is not any ear, much less any corn ; if the blade be blasted or dwarfed in our haste and greed for the full shock and its price, we spoil all three. It is not easy to keep this always before one's mind, that the young 'idea' is in a young body, and that healthy growth and harmless passing of the time are more to be cared for than what is vainly called accomplishment. We are preparing him to run his race, and accomplish that which is one of his chief ends; but we are too apt to start him off at his full speed, and he either bolts or breaks down-the worst thing for him generally being to win. In this way a child or boy should be regarded much more as a mean than as an end, and his cultivation should have reference to this; his mind, as old Montaigne said, should be forged, as well as-indeed, I would say, rather than -furnished, fed rather than filled,- - two not always coincident conditions. Now exercise-the joy of interest, of origination, of activity, of excitementthe play of the faculties, - this is the true life of a boy, not the accumulation of mere words. Wordsthe coin of thought-unless as the means of buying something else, are just as useless as other coin 


\section{Education through the Senses. 313}

when it is hoarded; and it is as silly, and in the true sense as much the part and lot of a miser, to amass words for their own sakes, as to keep all your guineas in a stocking and never spend them, but be satisfied with every now and then looking greedily at them and making them chink. Therefore it is that I dislike-as indeed who doesn't? - the cranming system. The great thing with knowledge and the young is to secure that it shall be their ownthat it be not merely external to their inner and real self, but shall go in succum et sanguinem; and therefore it is, that the self-teaching that a baby and a child give themselves remains with them for everit is of their essence, whereas what is given them $a b$ extra, especially if it be received mechanically, without relish, and without any energizing of the entire nature, remains pitifully useless and wersh. Try, therefore, always to get the resident teacher inside the skin, and who is for ever giving his lessons, to help you and be on your side.

Now in children, as we all know, he works chiefly through the senses. The quantity of accurate observation-of induction, and of deduction too (both of a much better quality than most of Mr. Buckle's); of reasoning from the known to the unknown; of inferring; the nicety of appreciation of the like and the unlike, the common and the rare, the odd and the even; the skill of the rough and the smooth- 
of form, of appearance, of texture, of weight, of all the minute and deep philosophies of the touch and of the other senses, - the amount of this sort of objective knowledge which every child of eight years has acquired - especially if he can play in the lap of nature and out of doors-and acquired for life, is, if we could only think of it, marvellous beyond any of our mightiest marches of intellect. Now, could we only get the knowledge of the school to go as sweetly and deeply and clearly into the vitals of the mind as this self-teaching has done, and this is the paradisiac way of it, we should make the young mind grow as well as learn, and be in understanding a man as well as in simplicity a child; we should get rid of much of that dreary, sheer endurance of their school-hours - that stolid lending of ears that do not hear - that objectless looking without ever once seeing, and straining their minds without an aim; alternating, it may be, with some feats of dexterity and effort, like a man trying to lift himself in his own arms, or take his head in his teeth, exploits as dangerous, as ungraceful, and as useless, except to glorify the showman and bring wages in, as the feats of an acrobat.

But you will ask, how is all this to be avoided if everybody must know how far the sun is from Georgium Sidus, and how much of phosphorus is in our bones, and of ptyalin and flint in human spittle 


\section{Education through the Senses. 3 I 5}

- besides some 10,000 times 10,000 other things which we must be told and try to remember, and which we cannot prove not to be true, but which I decline to say we know.

But is it necessary that everybody should know everything? Is it not much more to the purpose for every man, when his turn comes, to be able to do something; and I say, that other things being equal, a boy who goes bird-nesting, and makes a collection of eggs, and knows all their colours and spots, going. through the excitements and glories of getting them, and observing everything with a keenness, an intensity, an exactness, and a permanency, which only youth and a quick pulse, and fresh blood and spirits combined, can achieve, - a boy who teaches himself natural history in this way, is not only a healthier and happier boy, but is abler in mind and body for entering upon the great game of life, than the pale, nervous, bright-eyed, feverish, ' interesting' boy, with a big head and a small bottorn and thin legs, who is the 'captain,' the miracle of the school; dux for his brief year or two of glory, and, if he live, booby for life. I am, of course, not going in for a complete curriculum of general ignorance; but I am for calling the attention of teachers to drawing out the minds, the energies, the hearts of their pupils through their senses, as well as pouring in through these same 
apertures the general knowledge of mankind, the capital of the race, into this one small being, who it is to be hoped will contrive to forget much of the mere words he has unhappily learned.

For we may say of our time in all seriousness, what Sydney Smith said in the fulness of his wisdom and his fun, of the pantologic master of Trinity - Science is our forte; omniscience is our foible. There is the seed of a whole treatise, a whole organon in this joke; think over it, and let it simmer in your mind, and you will feel its significance and its power. Now, what is science so called to every 999 men in Iooo, but something that the one man tells them he has been told by some one else-who may be one among say 50,000 - is true, but of the truth of which these 999 men (and probably even the teaching thousandth man) can have no direct test, and, accordingly, for the truth or falsehood of which they, by a law of their nature, which rejects what has no savour and is superfluous, don't care one fig. How much better, how much dearer, and more precious in a double sense, because it has been bought by themselves, how much nobler is the knowledge which our little friend, young Edward Forbes, 'that marvellous boy,' for instance - and what an instance ! - is picking up, as he looks into everything he sees, and takes photographs upon his retina-the camera lucidu of 
his mind - which never fade, of every midge that washes its face as a cat does, and preens its wings, every lady-bird that alights on his knee, and folds and unfolds her gauzy pinions under their spotted and glorious lids. How more real is not only this knowledge, but this little knowledger in his entire nature, than the poor being who can maunder amazingly the entire circle of human science at second, or it may be, twentieth hand!

There are some admirable, though cursory re- . marks on 'Ornithology as a Branch of Liberal Education,' by the late Dr. Adams of Banchory, the great Greek scholar, in a pamphlet bearing this title, which he read as a paper before the last meeting of the British Association in Aberdeen. It is not only interesting as a piece of natural history, and a touching co-operation of father and son in the same field - the one on the banks of his own beautiful Dee and among the wilds of the Grampians, the other among the Himalayas and the forests of Cashmere; the son having been enabled, by the knowledge of his native birds got under his father's eye, when placed in an unknown country to recognise his old feathered friends, and to make new ones and tell their story; it is also valuable as coming from a man of enormous scholarship and knowledge-the most learned physician of his time - who knew Aristotle and Plato, and all those old 
fellows, as we know Maunder or Lardner-a hardworking country surgeon, who was ready to run at any one's call-but who did not despise the modern enlightenments of his profession, because they were not in Paulus Agineta; though, at the same time, he did not despise the admirable and industrious Paul because he was not up to the last doctrine of the nucleated cell, or did not read his Hippocrates by the blaze of paraffine; a man greedy of all knowledge, and welcoming it from all comers, but who, at the end of a long life of toil and thought, gave it as his conviction that one of the best helps to true education, one of the best counteractives to the necessary mischiefs of mere scientific teaching and information, was to be found in getting the young to teach themselves some one of the natural sciences, and singling out ornithology as one of the readiest and most delightful for such a life as his.

I end these intentionally irregular remarks by a story. Some years ago I was in one of the wildest recesses of the Perthshire Highlands. It was in autumn, and the little school, supported mainly by the Chief, who dwelt all the year round in the midst of his own people, was to be examined by the minister, whose native tongue, like that of his flock, was Gaelic, and who was as awkward and ineffectual, and sometimes as unconsciously inde- 


\section{Education through the Senses.}

corous, in his English, as a Cockney is in his kilt. It was a great occasion : the keen-eyed, firm-limbed, brown-cheeked little fellows were all in a buzz of excitement as we came in, and before the examination began every eye was looking at us strangers as a dog looks at his game, or when seeking it; they knew everything we had on, everything that could be known through their senses. I never felt myself so studied and scrutinized before. If any one could have examined them upon what they thus mastered, Sir Charles Trevelyan and John Mill would have come away astonished, and, I trust, humble. Well, then, the work of the day began; the mill was set a-going, and what a change! In an instant their eyes were like the windows of a house with the blinds down; no one was looking out; everything blank; their very features changed-their jaws fell, their cheeks flattened, they drooped and looked ill at ease-stupid, drowsy, sulky-and getting them to speak or think, or in any way to energize, was like trying to get any one to come to the window at three of a summer morning, when, if they do come, they are half awake, rubbing their eyes and growling. So with my little Celts. They were like an idle and half asleep collie by the fireside, as contrasted with the collie on the hill and in the joy of work; the form of $\operatorname{dog}$ and boy are there-he, the self of each, 
was elsewhere (for I differ from Professor Ferrier in thinking that the dog has the reflex ego, and is a very knowing being). I noticed that anything they really knew roused them somewhat; what they had merely to transmit or pass along, as if they were a tube through which the master blew the pea of knowledge into our faces, was performed as stolidly as if they were nothing but a tube.

At last the teacher asked where Sheffield was, and was answered; it was then pointed to by the dux, as a dot on a skeleton map. And now came a flourish. 'What is Sheffield famous for?' Blank stupor, hopeless vacuity, till he came to a sort of sprouting 'Dougal Cratur'-almost as wee, and as gleg, and as tousy about the head, as my own Kintail terrier, whom I saw at that moment through the open door careering after a hopeless rabbit, with much benefit to his muscles and his windwho was trembling with keenness. He shouted out something which was liker 'cutlery' than anything else, and was received as such amid our rapturous applause. I then ventured to ask the master to ask small and red Dougal what cutlery was; but from the sudden erubescence of his pallid, ill-fed cheek, and the alarming brightness of his eyes, I twigged at once that he didn't himself know what it meant. So I put the question myself, and was not surprised to find that not one of them, from 
Dougal up to a young strapping shepherd of eighteen, knew what it was!

I told them that Sheffield was famous for making knives and scissors, and razors, and that cutlery meant the manufacture of anything that cuts. Presto! and the blinds were all up, and eagerness, and nous, and brains at the window. I happened to have a Wharncliffe, with 'Rodgers and Sons, Sheffield,' on the blade. I sent it round, and finally presented it to the enraptured Dougal. Would not each one of those boys, the very boobiest there, know that knife again when they saw it, and be able to pass a creditable competitive examination on all its ins and outs? and wouldn't they remember 'cutlery' for a day or two? Well, the examination over, the minister performed an oration of much ambition and difficulty to himself and to us, upon the general question, and a great many other questions, into which his Gaelic subtlety fitted like the mists into the hollows of Ben-a-Houlich, with, it must be allowed, a somewhat similar tendency to confuse and conceal what was beneath; and he concluded with thanking the Chief, as he well might, for his generous support of 'this aixlent CEMETERY of ædication.' Cemetery indeed! The blind leading the blind, with the ancient result; the dead burying their dead.

Now, not greater is the change we made from that low, small, stifling, gloomy, mephitic room, into the 
glorious open air, the loch lying asleep in the sun, and telling over again on its placid face, as in a dream, every hill and cloud, and birch and pine, and passing bird and cradled boat; the Black Wood of Rannoch standing ' in the midst of its own darkness,' frowning out upon us like the Past disturbed, and far off in the clear ether, as in another and a better world, the dim shepherds of Etive pointing, like ghosts at noonday, to the weird shadows of Glencoe; -not greater was this change, than is that from the dingy, oppressive, weary 'cemetery' of mere word-knowledge to the open air, the light and liberty, the divine infinity and richness of nature and her teaching.

We cannot change our time, nor would we if we could. It is God's time as well as ours. And our time is emphatically that for achieving and recording and teaching man's dominion over and insight into matter and its forces-his subduing the earth; but let us turn now and then from our necessary and honest toil in this neo-Platonic cavern where we win gold and renown, and where we often are obliged to stand in our own light, and watch our own shadows as they glide, huge and mis-shapen, across the inner gloom; let us come out betimes with our gold, that we may spend it and get 'goods' for it, and when we can look forth on that ample world of daylight which we can never hope to overrun, and into that 


\section{Education through the Senses. 323}

overarching heaven where, amid clouds and storms, lighțing and sudden tempest, there are revealed to those who look for them, lucid openings into the pure, deep empyrean, 'as it were the very body of heaven in its clearness ;' and when, best of all, we may remember Who it is who stretched out these heavens as a tent to dwell in, and on whose footstool we may kneel, and out of the depths of our heart cry aloud,

Te Deum veneramur,

Te Sancte Pater!

we shall return into our cave, and to our work, all the better of such a lesson, and of such a reasonable service, and dig none the worse.

Science which ends in itself, or still worse, returns upon its maker, and gets him to worship himself, is worse than none; it is only when it makes it more clear than before who is the Maker and Governor, not only of the objects, but of the subjects of itself, that knowledge is the mother of virtue. But this is an endless theme. My only aim in these desultory hints is to impress parents and teachers with the benefits of the study, the personal engagement-with their own hands and eyes, and legs and ears-in some form or another of natural history, by their children and pupils and themselves, as counteracting evil, and doing immediate and actual good. Even the immense activity in the Post-Office-stamp line of 
business among our youngsters has been of immense use in many ways, besides being a diversion and an interest. I myself came to the knowledge of Queensland, and a great deal more, through its blue twopenny.

If any one wishes to know how far wise and clever and patriotic men may occasionally go in the way of giving 'your son' a stone for bread, and a serpent for a fish,--may get the nation's money for that which is not bread, and give their own labour for that which satisfies no one; industriously making sawdust into the shapes of bread, and chaff into the appearance of meal, and contriving, at wonderful expense of money and brains, to show what can be done in the way of feeding upon wind,- - let him take a turn through certain galleries of the Kensington Museum.

'Yesterday forenoon,' writes a friend, 'I went to South Kensington Museum. It is really an absurd collection. A great deal of valuable material and a great deal of perfect rubbish. The analyses are even worse than I was led to suppose. There is an ANALYSIS OF A MAN. First, a man contains so much water, and there you have the amount of water in a bottle; so much albumen, and there is the albumen; so much phosphate of lime, fat, hæmatin, fibrine, salt, etc. etc. Then in the rext case so much carbon; so much phosphorus-a bottle with sticks of phosphorus; so much potassium, and there is a bottle 


\section{Education through the Senses.}

with potassium; calcium, etc. They have not bottles of oxygen, hydrogen, chlorine, etc., but they have cubical pieces of wood on which is written "the quantity of oxygen in the human body would occupy the space of $170(e . g$.) cubes of the size of this," etc. etc.' And so with analysis of bread, etc. etc. What earthly good can this do any one?

No wonder that the bewildered beings whom I have seen wandering through these rooms, yawned inore frequently and more desperately than I ever observed even in church.

So then, cultivate observation, energy, handicraft, ingenuity, outness in boys, so as to give them a pursuit as well as a study. Look after the blade, and don't coax or crush the ear out too soon, and remember that the full corn in the ear is not due till the harvest. when the great School breaks up, and we must all dismiss and go our several ways. 



\section{'ATXÍNOIA-NEARNESS OF THE Nô̂ৎ- PRESENCE OF MIND.}

\section{'ERऽTOXIA : HAPPY GUESSING.}

'Depend upon it, a lucky guess is never merely luck-there is alivays some Talent in it.'-Miss AUsteN, in 'Emma.' 



\section{'ACX'́NOIA: NEARNESS OF THE Noûs.}

$D^{\text {R. CHALMERS used to say that in the dyna- }}$ mics of human affairs, two qualities were essential to greatness - Power and Promptitude. One man might have both, another power without promptitude, another promptitude without power. We must all feel the common sense of this, and can readily see how it applies to a general in the field, to a pilot in a storm, to a sportsman, to a fencer, to a debater. It is the same with an operating surgeon at all times, and may be at any time with the practitioner of the art of healing. He must be ready for what are called emergencies-cases which rise up at your feet, and must be dealt with on the instant,--he must have power and promptitude.

It is a curious condition of mind that this requires: it is like sleeping with your pistol under your pillow, and it on full cock; a moment lost and all may be lost. There is the very nick of time. This is what we mean by presence of mind ; by a man having such 
a subject at his finger-ends; that part of the mind lying nearest the outer world, and having to act on it through the bodily organs, through the will-the outposts must be always awake. It is of course, so to speak, only a portion of the mind that is thus needed and thus available; if the whole mind were for ever at the advanced post, it would soon lose itself in this endeavour to keep it. Now, though the thing needed to be done may be simple enough, what goes to the doing of it, and to the being at once ready and able to do it, involves much; the wedge would not be a wedge, or do a wedge's work, without the width behind as well as the edge in front. Your men of promptitude without genius or power, including knowledge and will, are those who present the wedge the wrong way. Thus your extremely prompt people are often doing the wrong thing, which is almost alıvays worse than nothing. Our vague friend who bit 'Yarrow's' tail instead of 'the Chicken's,' was full of promptitude; as was also that other man, probably a relative, who barred the door with a boiled carrot: each knew what was needed-the biting the tail, the barring the door; both erred as to the means-the one by want of presence of mind, the other by lack of mind itself. We must have just enough of the right knowledge and no more; we must have the habit of using this; we must have self-reliance, and the consentaneousness 


\section{Happy Guessing.}

of the entire mind; and whatsoever our hand finds to do, we must do it with our might. Therefore it is that this master act of the man, under some sudden and great unexpected crisis, is in a great measure performed unconsciously as to its mental means. The man is so totus in illo, that there is no bit of the mind left to watch and record the acts of the rest; therefore men, when they have done some signal feat of presence of mind, if asked how they did it, generally don't very well know-they just did it: it was, in fact, done and then thought of, not thought of and then done, in which case it would likely never have been done. Not that the act was uncaused by mind; it is one of the highest powers of mind thus to act; but it is done, if I may use the phrase, by an acquired instinct. You will find all this in that wonderful old Greek who was Alexander the Great's and the old world's schoolmaster, and ours if we were wise, whose truthfulness and clear insight one wonders at the longer he lives. He seems to have seen the human mind as a bird or an engineer does the earth -he knew the plan of it. We now-a-days see it as one sees a country, athwart and in perspective, and from the side; he saw it from above and from below. There are therefore no shadows, no foreshortenings, no clear-obscure, indeed no disturbing medium; it is as if he examined everything in vacuo. 
I refer my readers to what he says on 'A $\gamma \chi^{i}$ ivo

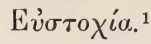

My object in what I have now written and am going to write, is to impress upon medical students the value of power and promptitude in combination, for their professional purposes; the uses to them of nearness of the Novs, and of happy guessing; and how you may see the sense, and neatness, and pith

${ }^{1}$ As I am now, to my sorrow and shame, too much of a mediate Grecian, I give a Balliol friend's note on these two words : - "What you have called "presence of mind" and " happy guessing " may, I think, be identified respectively with

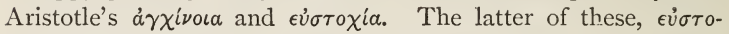
$\chi i a$, Aristotle mentions incidentally when treating of $\epsilon \dot{u} \beta o u \lambda i a$, or good deliberation. Eth. Nic. bk. vi. ch. 9. Good deliberation, he says, is not $\epsilon \dot{v} \sigma \tau o \chi i$, for the former is a slow process, whereas the latter is not guided by reason, and is rapid. In the same passage he tells us that aryivola is a sort of $\epsilon \dot{v} \sigma \tau o \chi i a$. But he speaks of árxivoı more fully in Ana. Post. I. 34 :"A $\gamma \chi$ inoıa is a sort of happy guessing at the intermediate, when there is not time for consideration: as when a man, seeing that the bright side of the moon is always turned towards the sun, comprehends that her light is borrowed from the sun; or concludes, from seeing one conversing with a capitalist that he wants to borrow money; or infers that people are friends from the fact of their having common enemies." And then he goes on to make these simple observations confused and perplexing by reducing them to his logical formula.

'The derivation of the words will confirm this view. Eं $\sigma \tau o$ $\chi^{i}$ ia is a hitting the mark successfully, a reaching to the end, the rapid, and, as it were, intuitive perception of the truth. This is what Whewell means by saying, "all induction is a happy conjecture." But when Aristotle says that this faculty

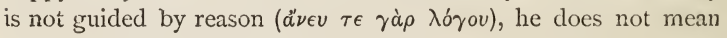




\section{Happy Guessing.}

of that excellent thinker, as well as best of all storytellers, Miss Austen, when she says in Emma, 'Depend upon it, a lucky guess is never merely luck, there is always some talent in it,'-talent here denoting intelligence and will in action. In all sciences except those called exact, this happy guessing plays a large part, and in none more than in medicine, which is truly a tentative art, founded upon likelihood, and

to imply that it grows up altogether independent of reason, any more than Whewell means to say that all the discoveries in the inductive sciences have been made by men taking "shots" at them, as boys at school do at hard passages in their Latin lessons. On the contrary, no faculty is so absolutely the child of reason as this faculty of happy guessing. It only attains to perfection after the reason has been long and painfully trained in the sphere in which the guesses are to be made. What Aristotle does mean is, that when it has attained perfection, we are not conscious of the share which reason has in its operation-it is so rapid that by no analysis can we detect the presence of reason in its action. Sir Isaac Newton seeing the apple fall, and thence "guessing" at the law of gravitation, is a good instance of $\epsilon \dot{v} \sigma \tau o \chi i a$.

' 'A $\gamma$ xivoca, on the other hand, is a nearness of mind; not a reaching to the end, but an apprehension of the best means; not a perception of the truth, but a perception of how the truth is to be supported. It is sometimes translated "sagacity," but readiness or presence of mind is better, as sagacity rather involves the idea of consideration. In matters purely intellectual

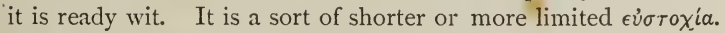
It is more of a natural gift than $\epsilon \dot{v} \sigma \tau o \chi i a$, because the latter is a far higher and nobler faculty, and therefore more dependent for its perfection on cultivation, as all our highest faculties are.

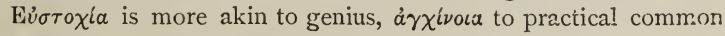
sense.' 
is therefore what we call contingent. Instead of this view of the healing art discouraging us from making our ultimate principles as precise as we should make our observations, it should urge us the more to this; for, depend upon it, that guess as we may often have to do, he will guess best, most happily for himself and his patient, who has the greatest amount of true knowledge, and the most serviceable amount of what we may call mental cash, ready money, and ready weapons.

We must not only have wisdom, which is knowledge assimilated and made our own, but we must, as the Lancashire men say and do, have wit to use it. We may carry a nugget of gold in our pocket, or a $£$ roo bank-note, but unless we can get it changed it is of little use, and we must moreover have the coin of the country we are in. This want of presence of mind-of having his wits about him, is as fatal to a surgeon as to a general.

That wise little man, Dr. Henry Marshall, little in body but not little in mind, in brain, and in worth, used to give an instance of this. A young, well-educated surgeon, attached to a regiment quartered at Musselburgh, went out professionally with two officers who were in search of 'satisfaction.' One fell shot in the thigh, and in half-an-hour after he was found dead, the surgeon kneeling pale and grim over him, with his two thumbs sunk in his thigh boloce the 


\section{Happy Gucssing.}

wound, the grass steeped in blood. If he had put them two inches higher, or extemporized a tourniquet with his sash and the pistol's ramrod and a stone, he might have saved his friend's life and his own-for he shot himself that night.

Here is another. Robbie Watson, whom I now see walking mildly about the streets--having taken to coal-was driver of the Dumfries coach by Biggar. One day he had changed horses, and was starting down a steep hill, with an acute turn at the foot, when he found his wheelers, two new horses, utterly ignorant of backing. They got furious, and we outside got alarmed. Robbie made an attempt to pull up, and then with an odd smile took his whip, gathered up his reins, and lashed the entire four into a gallop. If we had not seen his face we would have thought him a maniac; he kept them well together, and shot down like an arrow, as far as we could see to certain destruction. Right in front at the turn was a stout gate into a field, shut; he drove them straight at that, and through we went, the gate broken into shivers, and we finding ourselves safe, and the very horses enjoying the joke. I remember we emptied our pockets into Robbie's hat, which he liad taken off to wipe his head. Now, in a few seconds all this must have passed through his head'that horse is not a wheeler, nor that one either; we'll come to mischief; there's the gate; yes, I'll do' 
it.' And he did it; but then he had to do it with his might; he had to make it impossible for his four horses to do anything but toss the gate before them.

Here is another case. Dr. Reid of Peebles, long famous in the end of last and beginning of this century, as the Doctor of Tweeddale; a man of great force of character, and a true Philip, a lover of horses, saw one Fair day a black horse, entire, thoroughbred. The groom asked a low price, and would answer no questions. At the close of the fair the doctor bought him, amid the derision of his friends. Next morning he rode him up Tweed, came home after a long round, and had never been better carried. This went on for some weeks; the fine creature was without a fault. One Sunday morning, he was posting up by Neidpath at a great pace, the country people trooping into the town to church. Opposite the fine old castle, the thoroughbred stood stock still, and it needed all the doctor's horsemanship to counteract the law of projectiles; he did, and sat still, and not only gave no sign of urging the horse, but rather intimated that it was his particular desire that he should stop. He sat there a full hour, his friends making an excellent joke of it, and he declining, of course, all interference. At the end of the hour, the Black Duke, as he was called, turned one ear forward, then another, looked aside, shook himself, and moved on, his master in- 


\section{Happy Guessing.}

timating that this was exactly what he wished; and from that day till his death, some fifteen years after, never did these two friends allude to this little circumstance, and it was never repeated; though it turned out that he had killed his two men previously. The doctor must have, when he got him, said to himself, 'If he is not stolen there is a reason for his paltry price,' and he would go over all the possibilities. So that when he stood still, he would say, 'Ah, this is it ;' but then he saw this at once, and lost no time, and did nothing. Had he given the horse one dig with his spurs, or one cut with his whip, or an impatient jerk with his bit, the case would have failed. When a colt, it had been brutally used, and being nervous, it lost its judgment, poor thing, and lost its presence of mind.

One more instance of nearness of the Nov̂s. A lady was in front of her lawn with her children, when a mad dog made his appearance, pursued by the peasants. What did she do? What would you have done? Shut your eyes and think. She went straight to the dog, received its head in her thick stuff gown, between her knees, and muffling it up, held it with all her might till the men came up. No one was hurt. Of course, she fainted after it was all right.

We all know (but why should we not know again?) the story of the Grecian mother who saw her child 
sporting on the edge of the bridge. She knew that a cry would startle it over into the raging streamshe came gently near, and opening her bosom allured the little scapegrace.

I once saw a great surgeon, after settling a particular procedure as to a life-and-death operation, as a general settles his order of battle. He began his work, and at the second cut altered the entire conduct of the operation. No one not in the secret could have told this : not a moment's pause, not a quiver of the face, not a look of doubt. This is the same master power in man, which makes the difference between Sir John Moore and Sir John Cope.

Mrs. Major Robertson, a woman of slight make, great beauty, and remarkable energy, courage, and sense (she told me the story herself), on going up to her bedroom at night-there being no one in the house but a servant-girl, in the ground floor-saw a portion of a man's foot projecting from under the bed. She gave no cry of alarm, but shut the door as usual, set down her candle, and began as if to undress, when she said aloud to herself, with an impatient tone and gesture, 'I've forgotten that key again, I declare ;' and leaving the candle burning, and the door open, she went down stairs, got the watchman, and secured the proprietor of the foot, which had not moved an inch. How many women or men could have done, or rather have been all this ! 


\section{THE BLACK DWARF'S BONES.}

$$
\text { . . "If thou wert grim, }
$$

Lame, ugly, crooked, suurt, prodigious.'

KING JOHN. 



\section{THE BLACK DWARF'S BONES.}

THESE gnarled, stunted, useless old bones, 1 were all that David Ritchie, the original of the Black Dwarf, had for left femur and tibia, and we

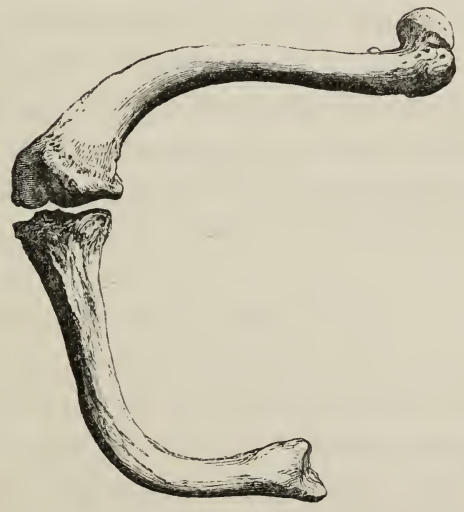

have merely to look at them, and add poverty, to know the misery summed up in their possession. They seem to have been blighted and rickety. 
The thigh-bone is very short and slight, and singularly loose in texture; the leg-bone is dwarfed, but dense and stout. They were given to me many years ago by the late Andrew Ballantyne, Esq., of Woodhouse (the Wudess, as they call it on Tweedside), and their genuineness is unquestionable.

As anything must be interesting about one once so forlorn and miserable, and whom our great wizard has made immortal, I make no apology for printing the following letters from my old friend, Mr. Craig, long surgeon in Peebles, and who is now spending his evening, after a long, hard, and useful day's work, in the quiet vale of Manor, within a mile or two of 'Cannie Elshie's' cottage. The picture he gives is very affecting, and should make us all thankful that we are 'wise-like.' There is much that is additional to Sir Walter's account, in his 'Author's Edition' of the Waverley Novels.

'Hall Manor, Thursday, May 20, I858.

' My DEAR SiR, - David Ritchie, alias Bowed I)avie, was born at Easter Happrew, in the parish of Stobo, in the year I74I. He was brought to Woodhouse, in the parish of Manor, when very young. His father was a labourer, and occupied a cottage on that farm; his mother, Anabel Niven, was a delicate woman, severely afflicted with rheumatism, and could not take care of him when an 


\section{The Black Dwarf's Bones.}

infant. To this cause he attributed his deformity, and this, if added to imperfect clothing, and bad food, and poverty, will account for the grotesque figure which he became. He never was at school, but he could read tolerably; had many books ; was fond of poetry, especially Allan Ramsay; he hated Burns. His father and mother both died early, and poor Davie became a homeless wanderer; he was two years at Broughton Mill, employed in stirring the husks of oats, which were used for drying the corn on the kiln, and required to be kept constantly in motion; he boasted, with a sort of rapture, of his doings there. From thence he went to Lyne's Mill, near his birthplace, where he continued one year at the same employment, and from thence he was sent to Edinburgh to learn brush-making, but made no progress in his education there; was annoyed by the wicked boys, or keelies, as he called them, and found his way back to Manor and Woodhouse. The farm now possessed by Mr. Ballantyne was then occupied by four tenants, among whom he lived; but his house was at Old Woodhouse, where the late Sir James Nasmyth built him a house with two apartments, and separate outer doors, one for himself exactly his own height when standing upright in it; and this stands as it was built, exactly four feet. A Mr. Ritchie, the father of the late minister of Athelstaneford, was 
then tenant; his wife and Davie could not agree, and she repeatedly asked her husband to put him away, by making the highest stone of his house the lowest. Ritchie left, his house was pulled down, and Davie triumphed in having the stones of his chimney-top made a step to his door, when this new house was built. He was not a little vindictive at times, when irritated, especially when any allusion was made to his deformity. On one occasion, he and some other boys were stealing pease in Mr. Gibson's field, who then occupied Woodhouse ; all the others took leg-bail, but Davie's locomotion being tardy, he was caught, shaken, and scolded by Gibson for all the rest. This he never forgot, and vowed to be avenged on the "auld sinner and deevil ;" and one day when Gibson was working about his own door, Davie crept up to the top of the house, which was low, and threw a large stone down on his head, which brought the old man to the ground. Davie crept down the other side of the house, got into bed beside his mother, and it was never known where the stone came from, till he boasted of it long afterwards. He only prayed that it might sink down through his "harn-pan" (his skull). His personal appearance seems to have been almost indescribable, not bearing any likeness to anything in this upper world. But as near as I can learn, his forehead was very narrow and low, sloping 


\section{The Black Dwarf's Bones.}

upwards and backward, something of the hatchet shape ; his eyes deep-set, small, and piercing; his nose straight, thin as the end of a cut of cheese, sharp at the point, nearly touching his fearfully projecting chin; and his mouth formed nearly a straight line; his shoulders rather high, but his body otherwise the size of ordinary men; his arms were remarkably strong. With very little aid he built a high garden wall, which still stands, many of the stones of huge size; these the shepherds laid to his directions. His legs beat all power of description; they were bent in every direction, so that Mungo Park, then a surgeon at Peebles, who was called to operate on him for strangulated hernia, said he could compare them to nothing but a pair of cork-screws; but the principal turn they took was from the knee outwards, so that he rested on his inner ankles, and the lower part of his tibias. The position of the bones in the woodcut, gives some, but a very imperfect idea of this ; the thrazon twisted limbs must have crossed each other at the knees, and looked more like roots than legs,

"An' his knotted knees play'd aye knoit between."

'He had never a shoe on his feet; the parts on which he walked were rolled in rags, old stockings, etc., but the toes always bare, even in the most severe weather. His mode of progressing was as extraordinary as his shape. He carried a long pole, or 


\section{$346 \quad$ Hora Subseciva.}

"kent," like the alpenstock, tolerably polished, with a turned top on it, on which he rested, placed it before him, he then lifted one leg, something in the manner that the oar of a boat is worked, and then the other, next advanced his staff, and repeated the operation, by diligently doing which he was able to make not very slow progress. - He frequently walked to Peebles, four miles, and back again, in one day. His arms had no motion at the elbowjoints, but were active enough otherwise. He was not generally ill-tempered, but furious when roused.

'Robert Craig.'

'Hall Manor, Fune 15,1858 .

'My dear Sir,-I have delayed till now to finish Bowed Davie, in the hope of getting more information, and to very little purpose. His contemporaries are now so few, old, and widely scattered, that they are difficult to be got at, and when come at, their memories are failed like their bodies. I have forgotten at what stage of his history I left off; but if I repeat you can omit the repetitions. Sir James Nasmyth, late of Posso, took compassion on the houseless, homeless lusus nature, and had a house built for him to his own directions; the door, winlow, and everything to suit his diminished, grotesque form; the door four feet high, the window twelve by eighteen inches, without glass, closed by a wooden 


\section{The Black Druarf's Bones.}

board, hung on leathern hinges, which he used to keep shut. Through it he reconnoitred all visitors, and only admitted ladies and particular favourites; he was very superstitious ; ghosts, fairies, and robbers he dreaded most. I have forgotten if I mentioned how he contrived to be fed and warmed. He had a small allowance from the parish poor-box, about fifty shillings; this was eked out by an annual peregrination through the parish, when some gave him food, others money, wool, etc., which he hoarded most miserly. How he cooked his food I have not been able to learn, for his sister, who lived in the same cottage with him, was separated by a stone-and-lime wall, and had a separate door of the usual size, and window to match, and was never allowed to enter his dwelling; but he brought home such loads, that the shepherds had to be on the look-out for him, when on his annual eleemosynary expeditions, to carry home part of his spoil. On one occasion a servant was ordered to give him some salt, for containing which he carried a long stocking; he thought the damsel had scrimped him in quantity, and he sat and distended the stocking till it appeared less than half full, by pressing down the salt, and then called for the gudewife, showed it her, and asked if she had ordered Jenny only to give him that wee pickle saut; the maid was scolded, and the stocking filled. $\mathrm{He}$ spent all his evenings at the back of the Woodhouse 
kitchen fire, and got at least one meal every day, where he used to make the rustics gape and stare at the many ghost, fairy, or robber stories which he had either heard of or invented, and poured out with unceasing volubility, and so often, that he believed them all true. But the Ballantyne family had no great faith in his veracity, when it suited his convenience to fib, exaggerate, or prevaricate, particularly when excited by his own lucubrations, or the waggery of his more intellectual neighbours and companions. He had a seat in the centre, which he always occupied, and a stool for his deformed feet and legs; they all rose at times, asking Davie to do likewise, and when he got upon his pins, he was shorter than when sitting, his body being of the ordinary length, and the deficiency all in his legs. On one occasion, a wag named Elder put up a log of wood opposite his loophole, made a noise, and told Davie that the robbers he dreaded so much were now at his house, and would not go away: he peeped out, saw the log, and exclaimed, "So he is, by the Lord God and my soul; Willie Elder, gi'e me the gun, and see that she is weel charged." Elder put in a very large supply of powder without shot, rammed it hard, got a stool, which Davie mounted, Elder handing him the gun, charging him to take time, and aim fair, for if he missed him, he would be mad at being shot at, be sure to come in, take 


\section{The Black Dwarf's Bones.}

everything in the house, cut their throats, and burn the house after. Davie tremblingly obeyed, presented the gun slowly and cautiously, drew the trigger; off went the shot, the musket rebounded, and back went Davie with a rattle on the floor. Some accomplice tumbled the log; Davie at length was encouraged to look out, and actually believed that he had shot the robber; said he had done for him now, "that ane wad plague him nae mair at ony rate." He took it into his head at one time that he ought to be married, and having got the consent of a haverel wench to yoke with him in the silken bonds of matrimony, went to the minister several times, and asked him to perform the ceremony. At length the minister sent him away, saying that he could not and would not accommodate him in the matter. Davie swung himself out at the door on his kent, much crest-fallen, and in great wrath, shutting the door with a bang behind him; but opening it again, he shook his clenched fist in the parson's face, and said, “Weel, weel, ye'll no let decent, honest folk marry; but, 'od, lad, I'se plenish your parish wi' bastards, to see what ye'll mak' o' that," and away he went. He read Hooke's Pantheon, and made great use of the heathen deities. He railed sadly at the taxes; some one observed that he need not grumble at them as he had none to pay. "Hae I no'?" he replied; "I can neither get 
a pickle snuff to my neb, nor a pickle tea to my mouth, but they maun tax 't." His sister and he were on very unfriendly terms. She was ill on one occasion; Miss Ballantyne asked how she was today. He replied, “I dinna ken, I ha'na been in, for I hate folk that are aye gaun to dee and never do 't." In I8I I he was seized with obstruction of the bowels and consequent inflammation; blisters and various remedies were applied for three days without effect. Some one came to Mrs. Ballantyne and said that it was "just about a' owre wi' Davie noo." She went, and he breathed his last almost immediately. His sister, without any delay, got his keys, and went to his secret repository, Mrs. Ballantyne thought to get dead-clothes, but instead, to her amazement, she threw three money-bags, one after another, into Mrs. Ballantyne's lap, telling her to count that, and that, and that. Mrs. B. was annoyed and astonished at the multitude of halfcrowns and shillings, all arranged according to value. He hated sixpences, and had none, but the third contained four guineas in gold. Mrs. B. was disgusted with the woman's greed, and put them all up, saying, what would anybody think if they came in and found them counting the man's money and his breath scarcely out,- - took it all home to her husband, who made out $£_{4}, 2$ s. in gold, $\mathfrak{f}_{\text {ro }}$ in a bank receipt, and $£_{7}, \mathrm{I} 8 \mathrm{~s}$. in shillings and half-crowns, in 
all $£ 22$. How did he get this? He had many visitors, the better class of whom gave him half-crowns, others shillings and sixpences; the latter he never kept, but converted them into shillings and halfcrowns whenever he got an opportunity. I asked the wright how he got him a coffin. He replied, "Easily; they made it deeper than ordinary, and wider, so as to let in his distorted legs, as it was impossible to streek him like others." He often expressed a resolve to be buried on the Woodhill top, three miles up the water from the churchyard, as he could never lie "amang the common trash;" however, this was not accomplished, as his friend, Sir James Nasmyth, who had promised to carry this wish into effect, was on the Continent at the time. When Sir James returned he spoke of having his remains lifted and buried where he had wished; but this was never done, and the expense of a railing and plantation of rowan-trees (mountain ash), his favourite prophylactic against the spells of witches and fairies, was abandoned. The Woodhill is a romantic, green little mount, situated at the west side of the Manor, which washes its base on the east, and separates it from Langhaugh heights, part of a lofty, rocky, and heathery mountain range, and on the west is the ruin of the ancient peel-house of old Posso, long the residence of the Nasmyth family. And now that we have the Dwarf dead and buried, comes the history 
of his resurrection in $182 \mathrm{I}$. His sister died exactly ten years after him. A report had been spread that he had been lifted and taken to dissecting-rooms in Glasgow, which at that period was the fate of many a more seemly corpse than Davie's; and the young men-for Manor had no sexton-who dug the sister's grave in the vicinity of her brother's, stimulated by curiosity to see if his body had really been carried off, and if still there what his bones were like, lifted them up, and carried them to Woodhouse, where they lay a considerable time, till they were sent to Mr. Ballantyne, then in Glasgow. Miss Ballantyne thinks the skull was taken away with the other bones, but put back again. I have thus given you all the information I can gather about the Black Dwarf, that I think worth narrating. It is reported that he sometimes sold a gill, but if this is true the Ballantynes. never knew it. Miss Ballantyne says that he was not ill-tempered, but on the contrary, kind, especially to children. She and her brother were very young when she went to Woodhouse, and her father objected to re-setting the farm from Sir James, on. account of the fearful accounts of his horrid temper and barbarous deeds, and Sir James said if he ever troubled them that he would immediately put him away; but he was very fond of the younger ones, played with them and amused them, though when roused and provoked by grown-up people, he raged, 


\section{The Black Dwarf's Bones.}

stormed, swore terrifically, and struck with anything that was near him, in short, he had an irritable but not a sulky, sour, misanthropic temper. The Messrs. Chambers wrote a book about him and his doings at a very early period of their literary history. Did I tell you of a female relative, Niven (whom he would never see), saying that she would come and streek him after he died? He sent word, "that if she offered to touch his corpse he would rive the thrapple oot o' her-he would raither be streekit by Auld Clootie's ain red-het hands."-Yours, truly obliged,

R. C.'

This poor, vindictive, solitary, and powerful creature, was a philocalist: he had a singular love of flowers and of beautiful women. He was a sort of Paris, to whom the blushing Aphrodites of the Glen used to come, and his judgment is said to have been as good, as the world generally thinks that of CEnone's handsome and faithless mate. His garden was full of the finest flowers, and it was his pleasure, when the young beauties

'Who bore the blue sky intermixed with flame In their fair eyes,'

came to him for their competitive examination, to scan them well, and then, without one word, present each with a flower, which was of a certain fixed and well-known value in Davie's standard calimeter. 
I have heard that there was one kind of rose, his $\kappa a \lambda \lambda \iota \sigma \tau \epsilon \hat{\imath} \mathrm{v}$, which he was known to have given only to three, and I remember seeing one of the three, when she was past seventy. Margaret Murray, or Morra, was her maiden name, and this fine old lady, whom an Oxonian would call a Double First, grave and silent, and bent with 'the pains,' when asked by us children, would, with some reluctance, and a curious grave smile, produce out of her Bible, Bowed Davie's withered and flattened rose : and from her looks, even then, I was inclined to affirm the decision of the connoisseur of Manor Water. One can fancy the scene in that sweet solitary valley, informed like its sister Yarrow with pastoral melancholy, with a young May, bashful and eager, presenting herself for honours, encountering from under that penthouse of eyebrows the steady gaze of the strange eldritch creature; and then his making up his mind, and proceeding to pluck his award and present it to her, 'herself a fairer flower ;' and then turning with a scowl, crossed with a look of tenderness, crawl into his den. Poor 'gloomy Dis,' slinking in alone.

They say, that when the candidate came, he surveyed her from his window, his eyes gleaming out of the darkness, and if he liked her not, he disappeared; if he would entertain her, he beckoned her into the garden. 


\section{The Black Dwarf's Bones.}

I have often thought that the Brozenie, of whom the south country legends are so full, must have been some such misshapen creature, strong, willing, and forlorn, conscious of his hideous forbidding looks, and ready to purchase affection at any cost of labour, with a kindly heart, and a longing for human sympathy and intercourse. Such a being looks like the prototype of the Aiken-Drum of our infancy, and of that 'drudging goblin,' of whom we all know how he

$$
\text { ‘. . Sweat }
$$

To earn his cream-bowl daily set, When in one night, ere glimpse of morn, His shadowy flail hath thresh'd the corn, That ten day lab'rers could not end; Then lies him down, the lubber ${ }^{1}$ fiend, And stretch'd out all the chimney's length, Basks at the fire his hairy strength, And cropful out of doors he flings, Ere the first cock his matin rings.'

My readers will, I am sure, more than pardon me tor giving them the following poem on Aiken-Drum, for the pleasure of first reading which, many years ago, I am indebted to Mr. R. Chambers's Popular Rhymes of Scotland, where its 'extraordinary merit' is generously acknowledged.

\section{THE BROWNIE OF BLEDNOCH.}

THERE cam' a strange wicht to our town-en', An' the fient a body did him ken ;

He tirl'd na lang, but he glided ben

Wi' a dreary, dreary hum.

' Lob-lye-by-the-fire. 
His face did glow like the glow o' the west, When the drumlie cloud has it half o'ercast;

Or the struggling moon when she's sair distrest,

O Sirs! 'twas Aiken-drum.

I trow the bauldest stood aback,

Wi' a gape an' a glow'r till their lugs did crack,

As the shapeless phantom mum'ling spak,

Hae ye wark for Aiken-drum?

O! had ye seen the bairns's fricht, As they stared at this wild and unyirthy wicht, As they skulkit in 'tween the dark an' the licht, An' graned out, Aiken-drum !

'Sauf us !' quoth Jock, 'd'ye see sick een ?' Cries Kate, 'There's a hole where a nose should ha' been ; An' the mouth's like a gash that a horn had ri'en ;

Wow! keep's frae Aiken-drum!'

The black dog growlin' cot'red his tail, The lassie swarf'd, loot fa' the pail ; Rob's lingle brack as he mendit the flail, At the sicht o' Aiken-drum.

His matted head on his breast did rest, A lang blue beard wan'ered down like a vest ; But the glare o' his e'e hath nae bard exprest, Nor the skimes o' Aiken-drum.

Roun' his hairy form there was naething seen, But a philabeg o' the rashes green, An' his knotted knees played aye knoit between ;

What a sicht was Aiken-drum!

On his wauchie arms three claws did meet, As they trail'd on the grun' by his taeless feet ;

E'en the auld gudeman himsel' did sweat,

To look at Aiken-drum. 


\section{The Black Drvarf's Bones.}

But he drew a score, himsel' did sain,

The auld wife tried, but her tongue was gane;

While the young ane closer clespit her wean,

And turn'd frae Aiken-drum.

But the canty auld wife cam till her braith, And she thocht the Bible might ward aff skaith ;

Be it benshee, bogle, ghaist, or wraith-

But it fear'd na' Aiken-drum.

'His presence protect us!' quoth the auld gudeman ;

'What wad ye, where won ye, - by sea or by lan'?

I conjure ye-speak-by the Beuk in my han'!'

What a grane gae Aiken-drum!

'I lived in a lan' whar we saw nae sky,

I dwalt in a spot whar a burn rins na by ;

But I'se dwall noo wi' you if ye like to try -

Hae ye wark for Aiken-drum?

'I'll shiel a' your sheep i' the mornin' sune, ${ }^{1}$

I'll berry your crap by the licht o' the moon,

An' ba the bairns wi' an unkenn'd tune,

If ye'll keep poor Aiken-drum.

'I'll loup the linn when ye canna wade, I'll kirn the kirn, and I'll turn the bread;

An' the wildest fillie that e'er can rede

I'se tame't,' quoth Aiken-drum.

' To wear the tod frae the flock on the fell-

To gather the dew frae the heather-bell-

1 On one occasion, Brownie had undertaken to gather the sheep into the bught by an early hour, and so zealously did he perform his task, that not only was there not one sheep left on the hill, but he had also collected a number of hares, which were found fairly penned along with them. Upon being congratulated on his extraordinary success, Brownie exclaimed, 'Confoond thae wee gray anes! they cost me mair trouble than a' the lave o' them.' 
An' to look at my face in your clear crystal well, Micht gie pleasure to Aiken-Drum.

'I'se seek nae guids, gear, bond, nor mark ;

I use nae beddin', shoon, nor sark ;

But a cogfu' o' brose 'tween the light an' the dark, Is the wage o' Aiken-drum.'

Quoth the wylie auld wife, 'The thing speaks weel ; Our workers are scant-we hae routh o' meal ; Gif he'll do as he says--be he man, be he de'il, Wow! we'll try this Aiken-drum.'

But the wenches skirl'd, 'He's no' be here! His eldritch look gars us swarf wi' fear ; An' the fient a ane will the house come near, If they think but o' Aiken-drum.

'For a foul and a stalwart ghaist is he, Despair sits broodin' aboon his e'e-bree, And unchancie to light o' a maiden's e'e,

Is the glower o' Aiken-drum.'

'Puir clipmalabors! ye hae little wit ; Is't na hallowmas noo, an' the crap out yet?'

Sae she seelenced them a' wi' a stamp o' her fit, 'Sit-yer-wa's-doun, Aiken-drum.'

Roun' a' that side what wark was dune, By the streamer's gleam, or the glance o' the moon ; A word, or a wish-an' the Brownie cam sune, Sae helpfu' was Aiken-drum.

But he slade aye awa or the sun was up, He ne'er could look straught on Macmillan's cup :'

'A communion cup, belonging to M'Millan, the well-known ousted minister of Balmaghie, and founder of the sect of Covenanters of his name. This cup was treasured by a zealous disciple in the parish of Kirkcowan, 


\section{The Black Dwarf's Bones.}

They watch'd-but nane saw him his brose ever sup,

Nor a spune sought Aiken-drum.

On Blednoch banks, an' on crystal Cree, For mony a day a toil'd wicht was he ;

And the bairns they play'd harmless roun' his knee, Sae social was Aiken-drum.

But a new-made wife, fu' o' rippish freaks, Fond o' a' things feat for the five first weeks, Laid a mouldy pair o' her ain man's breeks

By the brose o' Aiken-drum.

Let the learn'd decide when they convene, What spell was him an' the breeks between; For frae that day forth he was nae mair seen, An' sair miss'd was Aiken-drum.

He was heard by a herd gaun by the Thrieve, Crying, 'Lang, lang now may I greet an' grieve ; For alas! I hae gotten baith fee an' leave, O luckless Aiken-drum!'

Awa! ye wrangling sceptic tribe, Wi' your pro's an' your con's wad ye decide 'Gainst the 'sponsible voice o' a hale country-side On the facts 'bout Aiken-drum?

Tho' the 'Brownie o' Blednoch' lang be gane, The mark o' his feet's left on mony a stane; An' mony a wife an' mony a wean Tell the feats o' Aiken-drum?

E'en now, licht loons that gibe an' sneer At spiritual guests an' a' sic gear,

and long used as a test by which to ascertain the orthodoxy of suspected fersons. If, on taking it into his hand, the person trembled, or gave other symptoms of agitation, he was denounced as having bowed the knee to Baal, and sacrificed at the altar of idolatry. 
At the Glasnock mill hae swat wi' fear, An' look'd roun' for Aiken-drum,

An' guidly folks hae gotten a fricht, When the moon was set, an' the stars gied nae licht, At the roaring linn in the howe o' the nicht, Wi' sughs like Aiken-drum.

We would rather have written these lines than any amount of Aurora Leighs, Festuses, or such like, with all their mighty 'somethingness,' as Mr. Bailey would say. - For they, are they not the 'native wood-notes wild' of one of nature's darings? Here is the indescribable, inestimable, unmistakable impress of genius. Chaucer, had he been a Galloway man, might have written it, only he would have been more garrulous, and less compact and stern. It is like Tam o' Shanter, in its living union of the comic, the pathetic, and the terrible. Shrewdness, tenderness, imagination, fancy, humour, word-music, dramatic power, even witall are here. I have often read it aloud to children, and it is worth any one's while to do it. You will find them repeating all over the house for days such lines as take their heart and tongue.

The author of this noble ballad was William Nicholson, the Galloway poet, as he was, and is still called in his. own district. He was born at Tanimaus, in the parish of Borgue, in August I 783 ; 
he died circa I848, unseen, like a bird. Being extremely short-sighted, he was unfitted for being a shepherd or ploughman, and began life as a packman, like the hero of 'the Excursion;' and is still remembered in that region for his humour, his music, his verse, and his ginghams; and also, alas! for his misery and his sin. After travelling the country for thirty years, he became a packless pedlar, and fell into 'a way of drinking;' this led from bad to worse, and the grave closed in gloom over the ruins of a man of true genius. Mr. M'Diarmid of Dumfries prefixed a memoir of him to the Second Edition of his Tales in. Verse and Miscellaneous Poems. These are scarcely known out of Galloway, but they are worth the knowing: none of them have the concentration and nerve of the Brownie, but they are from the same brain and heart. 'The Country Lass,' a long poem, is excellent ; with much of Crabbe's power and compression. This, and the greater part of the volume, is in the Scottish dialect, but there is a Fable-the Butterfly and Beethe English and sense, the fine, delicate humour and turn of which might have been Cowper's ; and there is a bit of rugged sarcasm called 'Siller,' which Burns need not have been ashamed of. Poor Nicholson, besides his_turn for verse, was an exquisite musician, and sang with a powerful and sweet voice. One may imagine the delight of a lonely, town-end, when Willie 
the packman and the piper made his appearance, with his stories, and jokes, and ballads, his songs, and reels, and 'wanton wiles.'

There is one story about him which has always appeared to me quite perfect. A farmer in a remote part of Galloway, one June morning before sunrise, was awakened by music; he had been dreaming of heaven, and when he found himself awake, he still heard the strains. He looked out, and saw no one, but at the corner of a grass field he saw his cattle, and young colts and fillies, huddled together, and looking intently down into what he knew was an old quarry. He put on his clothes, and walked across the field, everything but that strange wild melody, still and silent in this 'the sweet hour of prime.' As he got nearer the 'beasts,' the sound was louder ; the colts with their long manes, and the nowt with their wondering stare, took no notice of him, straining their necks forward entranced. There, in the old quarry, the young sun 'glintin' on his face, and resting on his pack, which had been his pillow, was our Wandering Willie, playing and singing like an angel-'an Orpheus ; an Orpheus.' What a picture! When reproved for wasting his health and time by the prosaic farmer, the poor fellow said: 'Me and this quarry are lang acquant, and I've mair pleesure. in pipin' to thae daft cowts, than if the best leddies in the land were figurin' away afore me.' 
RAB AND HIS FRIENDS. 



\section{RAB AND HIS FRIENDS.}

FOUR-AND-THIRTY years ago, Bob Ainslie and I were coming up Infirmary Street from the High School, our heads together, and our arms intertwisted, as only lovers and boys know how, or why.

When we got to the top of the street, and turned north, we espied a crowd at the Tron Church. 'A dog-fight! shouted Bob, and was off; and so was I, both of us all but praying that it might not be over before we got up! And is not this boy-nature? and human nature too? and don't we all wish a house on fire not to be out before we see it? Dogs like fighting; old Isaac says they 'delight' in it, and for the best of all reasons; and boys are not cruel because they like to see the fight. They see three of the great cardinal virtues of $\operatorname{dog}$ or man -courage, endurance, and skill-in intense action. This is very different from a love of making dogs fight, and enjoying, and aggravating, and making 
gain by their pluck. A boy-be he ever so fond himself of fighting, if he be a good boy, hates and despises all this, but he would have run off with Bob and me fast enough: it is a natural, and a not wicked interest, that all boys and men have in witnessing intense energy in action.

Does any curious and finely-ignorant woman wish to know how Bob's eye at a glance announced a dog-fight to his brain? He did not, he could not see the dogs fighting; it was a flash of an inference, a rapid induction. The crowd round a couple of dogs fighting, is a crowd masculine mainly, with an occasional active, compassionate woman, fluttering wildly round the outside, and using her tongue and her hands freely upon the men, as so many 'brutes ;' it is a crowd annular, compact, and mobile; a crowd centripetal, having its eyes and its heads all bent downwards and inwards, to one common focus.

Well, Bob and I are up, and find it is not over: a small thoroughbred, white bull-terrier, is busy throttling a large shepherd's dog, unaccustomed to war, but not to be trifled with. They are hard at it; the scientific little fellow doing his work in great style, his pastoral enemy fighting wildly, but with the sharpest of teeth and a great courage. Science and breeding, however, soon had their own; the Game Chicken, as the premature Bob 


\section{Rab and his Friends.}

called him, working his way up, took his final grip of poor Yarrow's throat, - and he lay gasping and done for. His master, a brown, handsome, big young shepherd from Tweedsmuir, would have liked to have knocked down any man, would 'drink up Esil, or eat a crocodile,' for that part, if he had a chance : it was no use kicking the little dog; that would only make him hold the closer. Many were the means shouted out in mouthfuls, of the best possible ways of ending it. 'Water!' but there was none near, and many cried for it who might have got it from the well at Blackfriar's Wynd. 'Bite the tail!' and a large, vague, benevolent, middle-aged man, more desirous than wise, with some struggle got the bushy end of Yarrow's tail into his ample mouth, and bit it with all his might. This was more than enough for the much-enduring, much-perspiring shepherd, who, with a gleam of joy over his broad visage, delivered a terrific facer upon our large, vague, benevolent, middle-aged friend,who went down like a shot.

Still the Chicken holds; death not far off. 'Snuff! a pinch of snuff!' observed a calm, highly-dressed young buck, with an eye-glass in his eye. 'Snuff, indeed!' growled the angry crowd, affronted and glaring. 'Snuff! a pinch of snuff!' again observes the buck, but with more urgency; whereon were produced several open boxes, and from a mull which 
may have been at Culloden, he took a pinch, knelt down, and presented it to the nose of the Chicken. The laws of physiology and of snuff take their course; the Chicken sneezes, and Yarrow is free !

The young pastoral giant stalks off with Yarrow in his arms,-comforting him.

But the Bull Terrier's blood is up, and his soul unsatisfied; he grips the first dog he meets, and discovering she is not a dog, in Homeric phrase, he makes a brief sort of amende, and is off. The boys, with Bob and me at their head, are after him : down Niddry Street he goes, bent on mischief; up the Cowgate like an arrow-Bob and I, and our small men, panting behind.

There, under the single arch of the South Bridge, is a huge mastiff, sauntering down the middle of the causeway, as if with his hands in his pockets: he is old, grey, brindled, as big as a little Highland bull, and has the Shaksperian dewlaps shaking as he goes.

The Chicken makes straight at him, and fastens on his throat. To our astonishment, the great creature does nothing but stand still, hold himself up, and roar-yes, roar; a long, serious, remonstrative roar. How is this? Bob and I are uip to them. He is muzzled! The bailies had proclaimed a general muzzling, and his master, studying strength and economy mainly, had encompassed his huge jaws in 


\section{Rab and his Friends.}

a home-made apparatus, constructed out of the leather of some ancient breechin. His mouth was open as far as it could; his lips curled up in rage -a sort of terrible grin; his teeth gleaming, ready, from out the darkness; the strap across his mouth tense as a bowstring; his whole frame stiff with indignation and surprise; his roar asking us all round, 'Did you ever see the like of this?' He looked a statue of anger and astonishment, done in Aberdeen granite.

We soon had a crowd: the Chicken held on. 'A knife!' cried Bob; and a cobbler gave him his knife: you know the kind of knife, worn away obliquely to a point, and always keen. I put its edge to the tense leather; it ran before it; and then!-one sudden jerk of that enormous head, a sort of dirty mist about his mouth, no noise,- - and the bright and fierce little fellow is dropped, limp, and dead. A solemn pause : this was more than any of us had bargained for. I turned the little fellow over, and saw he was quite dead: the mastiff had taken him by the small of the back like a rat, and broken it.

He looked down at his victim appeased, ashamed, and amazed; snuffed him all over, stared at him, and taking a sudden thought, turned round and trotted off. Bob took the dead dog up, and said, 'John, we'll bury him after tea.' 'Yes,' said I, and was off after the mastiff. He made up the Cowgate 
at a rapid swing; he had forgotten some engagement. He turned up the Candlemaker Row, and stopped at the Harrow Inn.

There was a carrier's cart ready to start, and a keen, thin, impatient, black-a-vised little man, his hand at his grey horse's head, looking about angrily for something. 'Rab, ye thief!' said he, aiming a kick at my great friend, who drew cringing up, and avoiding the heavy shoe with more agility than dignity, and watching his master's eye, slunk dismayed under the cart,- - his ears down, and as much as he had of tail down too.

What a man this must be-thought I-to whom my tremendous hero turns tail! The carrier saw the muzzle hanging, cut and useless, from his neck, and I eagerly told him the story, which Bob and I always thought, and still think, Homer, or King David, or Sir Walter, alone were worthy to rehearse. The severe little man was mitigated, and condescended to say, 'Rab, ma man, puir Rabbie,' - whereupon the stump of a tail rose up, the ears were cocked, the eyes filled, and were comforted; the two friends were reconciled. 'Hupp !' and a stroke of the whip were given to Jess; and off went the three.

Bob and I buried the Game Chicken that night (we had not much of a tea) in the back-green of his house, in Melville Street, No. I7, with considerable 


\section{Rab and his Friends.}

gravity and silence; and being at the time in the Iliad, and, like all boys, Trojans, we of course called him Hector.

Six years have passed,- - a long time for a boy and a dog : Bob Ainslie is off to the wars; I am a medical student, and clerk at Minto House Hospital.

Rab I saw almost every week, on the Wednesday; and we had much pleasant intimacy. I found the way to his heart by frequent scratching of his huge head, and an occasional bone. When I did not notice him he would plant himself straight before me, and stand wagging that bud of a tail, and looking up, with his head a little to the one side. His master I occasionally saw ; he used to call me 'Maister John,' but was laconic as any Spartan.

One fine October afternoon, I was leaving the hospital, when I saw the large gate open, and in walked Rab, with that great and easy saunter of his. He looked as if taking general possession of the place; like the Duke of Wellington entering a subdued city, satiated with victory and peace. After him came Jess, now white from age, with her cart; and in it a woman carefully wrapped up,- the carrier leading the horse anxiously, and looking back. When he saw me, James (for his name was James 
Noble) made a curt and grotesque 'boo,' and said, 'Maister John, this is the mistress; she's got a trouble in her breest-some kind o' an income we're thinkin'.'

By this time I saw the woman's face; she was sitting on a sack filled with straw, with her husband's plaid round her, and his big-coat, with its large white metal buttons, over her feet.

I never saw a more unforgetable face-pale, serious, lonely, ${ }^{1}$ delicate, sweet, without being at all what we call fine. She looked sixty, and had on a mutch, white as snow, with its black ribbon; her silvery, smooth hair setting off her dark-grey eyes -eyes such as one sees only twice or thrice in a lifetime, full of suffering, full also of the overcoming of it: her eyebrows ${ }^{2}$ black and delicate, and her mouth firm, patient, and contented, which few mouths ever are.

As I have said, I never saw a more beautiful countenance, or one more subdued to settled quiet. 'Ailie,' said James, 'this is Maister John, the young doctor; Rab's freend, ye ken. We often speak aboot you, doctor.' She smiled, and made a move-

${ }^{1}$ It is not easy giving this look by one word; it was expressive of her being so much of her life alone. 


\section{Rab and his Friends.}

ment, but said nothing; and prepared to come down, putting her plaid aside and rising. Had Solomon, in all his glory, been handing down the Queen of Sheba at his palace gate, he could not have done it more daintily, more tenderly, more like a gentleman, than did James the Howgate carrier, when he lifted down Ailie his wife. The contrast of his small, swarthy, weather-beaten, keen, worldly face to herspale, subdued, and beautiful-was something wonderful. Rab looked on concerned and puzzled, but ready for anything that might turn up,-were it to strangle the nurse, the porter, or even me. Ailie and he seemed great friends.

'As I was sayin', she's got a kind o' trouble in her breest, doctor; wull ye tak' a look at it?' We walked into the consulting room, all four; Rab grim and comic, willing to be happy and confidential if cause could be shown, willing also to be the reverse, on the same terms. Ailie sat down, undid her open gown and her lawn handkerchief round her neck, and, without a word, showed me her right breast. I looked at and examined it carefully,- she and James watching me, and Rab eyeing all three. What could I say? there it was, that had once been so soft, so shapely, so white, so gracious and bountiful, so 'full of all blessed conditions,'- -hard as a stone, a centre of horrid pain, making that pale face, with its grey, lucid, reasonable eyes, and its sweet resolved mouth, 
express the full measure of suffering overcome. Why was that gentle, modest, sweet woman, clean and loveable, condemned by God to bear such a burden?

I got her away to bed. 'May Rab and me bide?' said James. 'You may; and Rab, if he will behave himself.' 'I'se warrant he's do that, doctor ;' and in slunk the faithful beast. I wish you could have seen him. There are no such dogs now. He belonged to a lost tribe. As I have said, he was brindled, and grey like Rubislaw granite; his hair short, hard, and close, like a lion's; his body thickset, like a little bull-a sort of compressed Hercules of a dog. He must have been ninety pounds' weight, at the least; he had a large blunt head; his muzzle black as night, his mouth blacker than any night, a tooth or two-being all he had-gleaming out of his jaws of darkness. His head was scarred with the records of old wounds, a sort of series of fields of battle all over it; one eye out, one ear cropped as close as was Archbishop Leighton's father's; the remaining eye had the power of two; and above it, and in constant communication with it, was a tattered rag of an ear, which was for ever unfurling itself, like an old flag; and then that bud of a tail, about one inch long, if it could in any sense he said to be long, being as broad as long-the mobility, the instantaneousness of that bud were 


\section{Rab and his Friends.}

very funny and surprising, and its expressive twinklings and winkings, the intercommunications between the eye, the ear, and it, were of the oddest and swiftest.

Rab had the dignity and simplicity of great size; and having fought his way all along the road to absolute supremacy, he was as mighty in his own line as Julius Cæsar or the Duke of Wellington, and had the gravity ${ }^{1}$ of all great fighters.

You must have often observed the likeness of certain men to certain animals, and of certain dogs to men. Now, I never looked at Rab without thinking of the great Baptist preacher, Andrew Fuller. ${ }^{2}$ The same large, heavy, menacing, combative, sombre, honest countenance, the same deep inevit-

${ }^{1}$ A Highland game-keeper, when asked why a certain terrier, of singular pluck, was so much more solemn than the other dogs, said, 'Oh, Sir, life's full o' sariousness to him-he just never can get eneuch o' fechtin'.'

${ }^{2}$ Fuller was, in early life, when a farmer lad at Soham, famous as a boxer; not quarrelsome, but not without 'the stern delight' a man of strength and courage feels in their exercise. Dr. Charles Stewart of Dunearn, whose rare gifts and graces as a physician, a divine, a scholar, and a gentleman, live only in the memory of those few who knew and survive him, liked to tell how Mr. Fuller used to say, that when he was in the pulpit, and saw a buirdly man come along the passage, he would instinctively draw himself up, measure his imaginary antagonist, and forecast how he would deal with him, his hands meanwhile condensing into fists, and tending to 'square.' He must have been a hard hitter if he boxed as he preached-what 'The Fancy' would call ' an ugly customer.' 
able eye, the same look, as of thunder asleep, but ready,-neither a dog nor a man to be trifled with.

Next day, my master, the surgeon, examined Ailie. There was no doubt it must kill her, and soon. It could be removed-it might never return-it would give her speedy relief-she should have it done. She curtsied, looked at James, and said, 'When?' 'To-morrow', said the kind surgeon-a man of few words. She and James and Rab and I retired. I noticed that he and she spoke little, but seemed to anticipate everything in each other. The following day, at noon, the students came in, hurrying up the great stair. At the first landing-place, on a small well-known black board, was a bit of paper fastened by wafers, and many remains of old wafers beside it. On the paper were the words,- 'An operation to-day.-J. B. Clerk.'

Up ran the youths, eager to secure good places: in they crowded, full of interest and talk. 'What's the case?' 'Which side is it?'

Don't think them heartless; they are neither better nor worse than you or I : they get over their professional horrors, and into their proper work; and in them pity, as an emotion, ending in itself or at best in tears and a long-drawn breath, lessens,while pity, as a motive, is quickened, and gains power and purpose. It is well for poor human nature that it is so. 


\section{Rab and his Friends.}

The operating theatre is crowded; much talk and fun, and all the cordiality and stir of youth. The surgeon with his staff of assistants is there. In comes Ailie : one look at her quiets and abates the eager students. That beautiful old woman is too much for them; they sit down, and are dumb, and gaze at her. These rough boys feel the power of her presence. She walks in quickly, but without haste; dressed in her mutch, her neckerchief, her white dimity short-gown, her black bombazeen petticoat, showing her white worsted stockings and her carpet shoes. Behind her was James with Rab. James sat down in the distance, and took that huge and noble head between his knees. Rab looked perplexed and dangerous; for ever cocking his ear and dropping it as fast.

Ailie stepped up on a seat, and laid herself on the table, as her friend the surgeon told her; arranged herself, gave a rapid look at James, shut her eyes, rested herself on me, and took my hand. The operation was at once begun; it was necessarily slow; and chloroform-one of God's best gifts to his suffering children-was then unknown. The surgeon did his work. The pale face showed its pain, but was still and silent. Rab's soul was working within him ; he saw that something strange was going on,--blood flowing from his mistress, and she suffering; his ragged ear was up, and importunate; he growled 
and gave now and then a sharp impatient yelp; he would have liked to have done something to that man. But James had him firm, and gave him a glower from time to time, and an intimation of a possible kick;-all the better for James, it kept his eye and his mind off Ailie.

It is over: she is dressed, steps gently and decently down from the table, looks for James; then turning to the surgeon and the students, she curtsies, - and in a low, clear voice, begs their pardon if she has behaved ill. The students-all of us-wept like children; the surgeon happed her up carefully,and, resting on James and me, Ailie went to her room, Rab following. We put her to bed. James took off his heavy shoes, crammed with tackets, heelcapt and toe-capt, and put them carefully under the table, saying, 'Maister John, I'm for nane o' yer strynge nurse bodies for Ailie. I'll be her nurse, and I'll gang aboot on my stockin' soles as canny as pussy.' And so he did; and handy and clever, and swift and tender as any woman, was that hornyhanded, snell, peremptory little man. Everything she got he gave her: he seldom slept; and often I saw his small shrewd eyes out of the darkness, fixed on her. As before, they spoke little.

Rab behaved well, never moving, showing us how meek and gentle he could be, and occasionally, in his sleep, letting us know that he was demolishing 
some adversary. He took a walk with me every day, generally to the Candlemaker Row; but he was sombre and mild; declined doing battle, though some fit cases offered, and indeed submitted to sundry indignities; and was always very ready to turn, and came faster back, and trotted up the stair with much lightness, and went straight to that door.

Jess, the mare, had been sent, with her weatherworn cart, to Howgate, and had doubtless her own dim and placid meditations and confusions, on the absence of her master and Rab, and her unnatural freedom from the road and her cart.

For some days Ailie did well. The wound healed 'by the first intention;' for as James said, 'Oor Ailie's skin's ower clean to beil.' The students came in quiet and anxious, and surrounded her bed. She said she liked to see their young, honest faces. The surgeon dressed her, and spoke to her in his own short kind way, pitying her through his eyes, Rab and James outside the circle,- - Rab being now reconciled, and even cordial, and having made up his mind that as yet nobody required worrying, but, as you may suppose, semper paratus.

So far well : but, four days after the operation, my patient had a sudden and long shivering, a 'groosin', as she called it. I saw her soon after; her eyes were too bright, her cheek coioured; she was restless, and ashamed of being so ; the balance was lost ; mischief 
had begun. On looking at the wound, a blush of red told the secret; her pulse was rapid, her breathing anxious and quick, she wasn't herself, as she said, and was vexed at her restlessness. We tried what we could. James did everything, was everywhere; never in the way, never out of it; Rab subsided under the table into a dark place, and was motionless, all but his eye, which followed every one. Ailie got worse; began to wander in her mind, gently; was more demonstrative in her ways to James, rapid in her questions, and sharp at times. He was vexed, and said, 'She was never that way afore, no, never.' For a time she knew her head was wrong, and was always asking our pardon - the dear gentle old woman : then delirium set in strong, without pause. Her brain gave way, and then came that terrible spectacle,

' The intellectual power, through words and things, Went sounding on, a dim and perilous way ;'

she sang bits of old songs and Psalms, stopping suddenly, mingling the Psalms of David, and the diviner words of his Son and Lord, with homely odds and ends and scraps of ballads.

Nothing more touching, or in a sense more strangely beautiful, did I ever witness. Her tremulous, rapid, affectionate, eager, Scotch voice, - the swift, aimless, bewildered mind, the baffled utterance, the bright and perilous eye ; some wild words, 


\section{Rab and his Friends.}

some household cares, something for James, the names of the dead, Rab called rapidly and in a 'fremyt' voice, and he starting up, surprised, and slinking off as if he were to blame somehow, or had been dreaming he heard. Many eager questions and beseechings which James and I could make nothing of, and on which she seemed to set her all, and then sink back ununderstood. It was very sad, but better than many things that are not called sad. James hovered about, put out and miserable, but active and exact as ever; read to her, when there was a lull, short bits from the Psalms, prose and metre, chanting the latter in his own rude and serious way, showing great knowledge of the fit words, bearing up like a man, and doating over her as his 'ain Ailie.' 'Ailie, ma woman!' 'Ma ain bonnie wee dawtie!'

The end was drawing on: the golden bowl was breaking; the silver cord was fast being loosed that animula, blandula, vagula, hospes, comesque, was about to flee. The body and the soul - companions for sixty years - were being sundered, and taking leave. She was walking, alone, through the valley of that shadow, into which one day we must all enter,-and yet she was not alone, for we know whose rod and staff were comforting her.

One night she had fallen quiet, and as we hoped, asleep; her eyes were shut. We put down the gas, 
and sat watching her. Suddenly she sat up in bed, and taking a bed-gown which was lying on it rolled up, she held it eagerly to her breast,- - to the right side. We could see her eyes bright with a surprising tenderness and joy, bending over this bundle of clothes. She held it as a woman holds her sucking child; opening out her night-gown impatiently, and holding it close, and brooding over it, and murmuring foolish little words, as over one whom his mother comforteth, and who sucks and is satisfied. It was pitiful and strange to see her wasted dying look, keen and yet vague--her immense love.

'Preserve me!' groaned James, giving way. And then she rocked back and forward, as if to make it sleep, hushing it, and wasting on it her infinite fondness. 'Wae's me, doctor; I declare she's thinkin' it's that bairn.' 'What bairn?' 'The only bairn we ever had; our wee Mysie, and she's in the Kingdom forty years and mair.' It was plainly true: the pain in the breast, telling its urgent story to a bewildered, ruined brain, was misread and mistaken; it suggested to her the uneasiness of a breast full of milk, and then the child; and so again once more they were together, and she had her ain wee Mysie in her bosom.

This was the close. She sank rapidly: the delirium left her; but, as she whispered, she was 'clean silly;' it was the lightening before the final dark- 


\section{Rab and his Friends.}

ness. After having for some time lain still - her eyes shut, she said, 'James!' He came close to her, and lifting up her calm, clear, beautiful eyes, she gave him a long look, turned to me kindly but shortly, looked for Rab but could not see him, then turned to her husband again, as if she would never leave off looking, shut her eyes and composed herself. She lay for some time breathing quick, and passed away so gently, that when we thought she was gone, James, in his old-fashioned way, held the mirror to her face. After a long pause, one small spot of dimness was breathed out; it vanished away, and never returned, leaving the blank clear darkness without a stain. 'What is our life? it is even a vapour, which appeareth for a little time, and then vanisheth away.'

Rab all this time had been full awake and motionless : he came forward beside us: Ailie's hand, which James had held, was hanging down; it was soaked with his tears; Rab licked it all over carefully, looked at her, and returned to his place under the table.

James and I sat, I don't know how long, but for some time,--saying nothing; he started up abruptly, and with some noise went to the table, and putting his right fore and middle fingers each into a shoe, pulled them out, and put them on, breaking one of the leather latchets, and muttering in anger, 'I never did the like o' that afore !' 
I believe he never did; nor after either. 'Rab!' he said roughly, and pointing with his thumb to the bottom of the bed. Rab leapt up, and settled himself; his head and eye to the dead face. 'Maister John, ye'll wait for me,' said the carrier; and disappeared in the darkness, thundering down stairs in his heavy shoes. I ran to a front window : there he was, already round the house, and out at the gate, fleeing like a shadow.

I was afraid about him, and yet not afraid; so I sat down beside Rab, and being wearied, fell asleep. I awoke from a sudden noise outside. It was November, and there had been a heavy fall of snow. Rab was in statu quo; he heard the noise too, and plainly knew it, but never moved. I looked out; and there, at the gate, in the dim morning-for the sun was not up, was Jess and the cart,- - cloud of steam rising from the old mare. I did not see James; he was already at the door, and came up the stairs and met me. It was less than three hours since he left, and he must have posted out-who knows how? - to Howgate, full nine miles off; yoked Jess, and driven her astonished into town. He had an armful of blankets, and was streaming with perspiration. He nodded to me, spread out on the floor two pairs of clean old blankets having at their corners, 'A. G., I794,' in large letters in red worsted. These were the initials of Alison Græme, 
and James may have looked in at her from without -himself unseen but not unthought of - when he was 'wat, wat, and weary,' and after having walked many a mile over the hills, may have seen her sitting, while ' $a$ ' the lave were sleepin', and by the firelight working her name on the blankets, for her ain James's bed.

He motioned Rab down, and taking his wife in his arms, laid her in the blankets, and happed her carefully and firmly up, leaving the face uncovered ; and then lifting her, he nodded again sharply to me, and with a resolved but utterly miserable face, strode along the passage, and down stairs, followed by Rab. I followed with a light; but he didn't need it. I went out, holding stupidly the candle in my hand in the calm frosty air; we were soon at the gate. I could have helped him, but I saw he was not to be meddled with, and he was strong, and did not need it. He laid her down as tenderly, as safely, as he had lifted her out ten days before-as tenderly as when he had her first in his arms when she was only 'A. G.' - - sorted her, leaving that beautiful sealed face open to the heavens; and then taking Jess by the head, he moved away. He did not notice me, neither did Rab, who presided behind the cart.

I stood till they passed through the long shadow of the College, and turned up Nicolson Street. I 
heard the solitary cart sound through the streets, and die away and come again; and I returned, thinking of that company going up Libberton Brae, then along Roslin Muir, the morning light touching the Pentlands, and making them like on-looking ghosts ; then down the hill through Auchindinny woods, past 'haunted Woodhouselee;' and as daybreak came sweeping up the bleak Lammermuirs, and fell on his own door, the company would stop, and James would take the key, and lift Ailie up again, laying her on her own bed, and, having put Jess up, would return with $\mathrm{Rab}$ and shut the door.

James buried his wife, with his neighbours mourning, Rab watching the proceedings from a distance. It was snow, and that black ragged hole would look strange in the midst of the swelling spotless cushion of white. James looked after everything; then rather suddenly fell ill, and took to bed; was insensible when the doctor came, and soon died. A sort of low fever was prevailing in the village, and his want of sleep, his exhaustion, and his misery made him apt to take it. The grave was not difficult to re-open. A fresh fall of snow had again made all things white and smooth; Rab once more looked on, and slunk home to the stable.

And what of Rab? I asked for him next week at the new carrier who got the goodwill of James's 


\section{Rab and his Friends.}

business, and was now master of Jess and her cart. 'How's Rab?' He put me off, and said rather rudely, 'What's your business wi' the dowg?' I was not to be so put off. 'Where's Rab?' He, getting confused and red, and intermeddling with his hair, said, 'Deed, sir, Rab's deid.' 'Dead! what did he die of?' 'Weel, sir,' said he, getting redder, 'he didna exactly dee; he was killed. I had to brain him wi' a rack-pin; there was nae doin' wi' him. He lay in the treviss wi' the mear, and wadna come oot. I tempit him wi' kail and meat, but he wad tak naething, and keepit me frae feedin' the beast, and he was aye gur gurrin', and grup gruppin' me by the legs. I was laith to mak' awa wi' the auld dowg, his like wasna atween this and Thornhill,but, 'deed, sir, I could do naething else.' I believed him. Fit end for Rab, quick and complete. His teeth and his friends gone, why should he keep the peace, and be civil?

He was buried in the braeface, near the burn, the children of the village, his companions, who used to make very free with him and sit on his ample stomach, as he lay half asleep at the door in the sun, watching the solemnity. 



\section{' With BR AINS, Sir.'}

'Multi multa sciunt, pauci multum.'

'It is one thing to wish to have truth on our side, and another thing to wish to be on the side of truth.'-WHATELy.

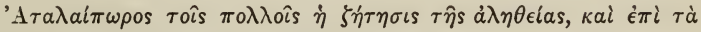

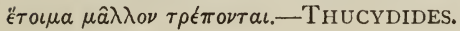

' The most perfect philosophy of the natural kind, only staves off our IGNORANCE a little longer; as, perhaps, the most perfect philosophy of the moral or metaphysical kind, serves only to discover larger portions of it.'-DAviD HUME. 



\section{'With BRAINS, Sir.'}

PRAY, Mr. Opie, may I ask what you mix your colours with?' said a brisk dilettante student to the great painter. 'With Brains, Sir,' was the gruff reply - and the right one. It did not give much of what we call information; it did not expound the principles and rules of the art; but, if the inquirer had the commodity referred to, it would awaken him; it would set him a-going, a-thinking, and a-painting to good purpose. If he had not the wherewithal, as was likely enough, the less he had to do with colours and their mixture the better. Many other artists, when asked such a question, would have either set about detailing the mechanical composition of such and such colours, in such and such proportions, rubbed up so and so; or perhaps they would (and so much the better, but not the best) have shown him how they laid them on; but even this would leave him at the critical point. Opie preferred going to the quick and the heart of the matter: 'With Brains, Sir.' 
Sir Joshua Reynolds was taken by a friend to see a picture. He was anxious to admire it, and he looked it over with a keen and careful but favourable eye. 'Capital composition; correct drawing; the colour, tone, chiaroscuro excellent; but-butit wants, hang it, it wants-That!' snapping his fingers; and, wanting ' that,' though it had everything else, it was worth nothing.

Again, Etty was appointed teacher of the students of the Royal Academy, having been preceded by a clever, talkative, scientific expounder of æsthetics, who delighted to tell the young men how everything was done, how to copy this and how to express that. A student came up to the new master, 'How should I do this, Sir?' 'Suppose you try.' Another, 'What does this mean, Mr. Etty?' 'Suppose you look.' 'But I have looked.' 'Suppose you look again.' And they did try, and they did look, and looked again; and they saw and achieved what they never could have done, had the how or the what (supposing this possible, which it is not in its full and highest meaning) been told them, or done for them; in the one case, sight and action were immediate, exact, intense, and secure; in the other, mediate, feeble, and lost as soon as gained. But what are 'Brains?' what did Opie mean? and what is Sir Joshua's 'That?' What is included in it? and what is the use, or the need of trying and trying, of missing often before you 
hit, when you can be told at once and be done with it ; or of looking when you may be shown? Everything in medicine and in painting--practical artsas means to ends, let their scientific enlargement be ever so rapid and immense, depends upon the right answers to these questions.

First of all, 'brains,' in the painter, are not diligence, knowledge, skill, sensibility, a strong will, or a high aim,- - he may have all these, and never paint anything so truly good and effective as the rugged woodcut we must all remember, of Apollyon bestriding the whole breadth of the way, and Christian girding at him like a man, in the old sixpenny Pilgrim's Progress; and a young medical student may have zeal, knowledge, ingenuity, attention, a good eye and a steady hand - he may be an accomplished anatomist, stethoscopist, histologist, and analyst; and yet, with all this, and all the lectures, and all the books, and all the sayings, and all the preparations, drawings, tables, and other helps of his teachers, crowded into his memory or his notebooks, he may be beaten at treating a whitlow or a colic, by the nurse in the wards where he was clerk, or by the old country doctor who brought him into, the world, and who listens with such humble wonder to his young friend's account, on his coming home after each session, of all he had seen and done, - of all the last astonishing discoveries and 
operations of the day. What the painter wants, in addition to, and as the complement of, the other elements, is genius and sense; what the doctor needs to crown and give worth and safety to his accomplishments, is sense and genius: in the first case, more of this, than of that; in the second, more of that, than of this. These are the 'Brains' and the 'That.'

And what is genius? and what is sense? Genius is a peculiar native aptitude, or tendency, to any one calling or pursuit over all others. A man may have a genius for governing, for killing, or for curing the greatest number of men, and in the best possible manner : a man may have a genius for the fiddle, or his mission may be for the tight-rope, or the Jew's harp ; or it may be a natural turn for seeking, and finding, and teaching truth, and for doing the greatest possible good to mankind; or it may be a turn equally natural for seeking, and finding, and teaching a lie, and doing the maximum of mischief. It was as natural, as inevitable, for Wilkie to develop himself into a painter, and such a painter as we know him to have been, as it is for an acorn when planted to grow up into an oak, a specific Quercus robur. But genius, and nothing else, is not enough, even for a painter: he must likewise have sense; and what is sense? Sense drives, or ought to drive, the coach; sense regulates, combines, restrains, commands, all 
the rest--even the genius; and sense implies exactness and soundness, power and promptitude of mind.

Then for the young doctor, he must have as his main, his master faculty, SENSE-Brains-vô̂s, justness of mind, because his subject-matter is one in which principle works, rather than impulse, as in painting; the understanding has first to do with it, however much it is worthy of the full exercise of the feelings and the affections. But all will not do, if GENIUS is not there,- - a real turn for the profession. It may not be a liking for it-some of the best of its practitioners never really liked it, at least liked other things better; but there must be a fitness of faculty of body and mind for its full, constant, exact pursuit. This sense and this genius, such a special therapeutic gift, had Hippocrates, Sydenham, Pott, Pinel, John Hunter, Delpech, Dupuytren, Kellie, Cheyne, Baillie, and Abercrombie. We might, to pursue the subject, pick out painters who had much genius and little or no sense, and vice versâ; and physicians and surgeons, who had sense without genius, and genius without sense, and some perhaps who had neither, and yet were noticeable, and, in their own side-ways, useful men.

But our great object will be gained if we have given our young readers (and these remarks are addressed exclusively to students) any idea of what we 
mean, if we have made them think, and look inwards. The noble and sacred science you have entered on is large, difficult, and deep, beyond most others; it is every day becoming larger, deeper, and in many senses more difficult, more complicated and involved. It requires more than the average intellect, energy, attention, patience, and courage, and that singular but imperial quality, at once a gift and an acquirement, presence of mind-áyxívoı, or nearness of the vovs, as the subtle Greeks called it-than almost any other department of human thought and action, except perhaps that of ruling men. Therefore it is, that we hold it to be of paramount importance that the parents, teachers, and friends of youths intended for medicine, and above all, that those who examine them on their entering on their studies, should at least (we might safely go much further) satisfy themselves as far as they can, that they are not below par in intelligence; they may be deficient and unapt quâ medici, and yet, if taken in time, may make excellent men in other useful and honourable callings.

But suppose we have got the requisite amount and specific kind of capacity, how are we to fill it with its means; how are we to make it effectual for its end? On this point we say nothing, except that the fear now-a-days, is rather that the mind gets too much of too many things, than too little or 


\section{' With Brains, Sir.'}

too few. But this means of turning knowledge to action, making it what Bacon meant when he said it was power, invigorating the thinking substance-giving tone, and you may call it muscle and nerve, blood and bone, to the mind-a firm gripe, and a keen and sure eye: that, we think, is far too little considered or cared for at present, as if the mere act of filling in everything for ever into a poor lad's brain, would give him the ability to make anything of it, and above all, the power to appropriate the small portions of true nutriment, and reject the dregs.

One comfort we have, that in the main, and in the last resort, there is really very little that can be done for any man by another. Begin with the sense and the genius - the keen appetite and the good digestion - and, amid all obstacles and hardships, the work goes on merrily and well; without these, we all know what a laborious affair, and a dismal, it is to make an incapable youth apply. Did any of you ever set yourselves to keep up artificial respiration, or to trudge about for a whole night with a narcotized victim of opium, or transfused blood (your own, perhaps) into a poor, fainting, exanimate wretch? If so, you will have some idea of the heartless attempt, and its generally vain and miserable result, to make a dull student apprehend-a debauched, interested, knowing, or active in any. 
thing beyond the base of his brain-a weak, etiolated intellect hearty, and worth anything; and yet how many such are dragged through their dreary curricula, and by some miraculous process of cramming, and equally miraculous power of turning their insides out, get through their examinations : and then - what then? providentially, in most cases, they find their level; the broad daylight of the world-its shrewd and keen eye, its strong instinct of what can, and what cannot serve its purpose-puts all, except the poor object himself, to rights; happy is it for him if he turns to some new and more congenial pursuit in time.

But it may be asked, how are the brains to be strengthened, the sense quickened, the genius awakened, the affections raised - the whole man turned to the best account for the cure of his fellow-men? How are you, when physics and physiology are increasing so marvellously, and when the burden of knowledge, the quantity of transferable information, of registered facts, of current names - and such names!-is so infinite: how are you to enable a student to take all in, bear up under all, and use it as not abusing it, or being abused by it? You must invigorate the containing and sustaining mind, you must strengthen him from within, as well as fill him from without; you must discipline, nourish, edify, relieve, and refresh his 


\section{' With Brains, Sir.'}

entire nature; and how? We have no time to go at large into this, but we will indicate what we mean :- encourage languages, especially French and German, at the early part of their studies; encourage not merely the book knowledge, but the personal pursuit of natural history, of field botany, of geology, of zoology; give the young, fresh, unforgetting eye, exercise and free scope upon the infinite diversity and combination of natural colours, forms, substances, surfaces, weights, and sizes everything, in a word, that will educate their eye or ear, their touch, taste, and smell, their sense of muscular resistance; encourage them by prizes, to make skeletons, preparations, and collections of any natural objects; and, above all, try and get hold of their affections, and make them put their hearts into their work. Let them, if possible, have the advantage of a regulated tutorial, as well as the ordinary professorial system. Let there be no excess in the number of classes and frequency of lectures. Let them be drilled in composition; by this we mean the writing and spelling of correct plain English (a matter not of every-day occurrence, and not on the increase) - let them be directed to the best books of the old masters in medicine, and examined in them,- - let them be encouraged in the use of a wholesome and manly literature. We do not mean popular or even modern literature--such as Emerson, Bulwer, or Alison, or 
the trash of inferior periodicals or novels-fashion, vanity, and the spirit of the age, will attract them readily enough to all these; we refer to the treasures of our elder and better authors. If our young medical student would take our advice, and for an hour or two twice a week take up a volume of Shakspere, Cervantes, Milton, Dryden, Pope, Cowper, Montaigne, Addison, Defoe, Goldsmith, Fielding, Scott, Charles Lamb, Macaulay, Jeffrey, Sydney Smith, Helps, Thackeray, etc., not to mention authors on deeper and more sacred subjects - they would have happier and healthier minds, and make none the worse doctors. If they, by good fortune-for the tide has set in strong against the literce humanioreshave come off with some Greek or Latin, we would supplicate for an ode of Horace, a couple of pages of Cicero or of Pliny once a month, and a page of Xenophon. French and German should be mastered either before or during the first years of study. They will never afterwards be acquired so easily or so thoroughly, and the want of them may be bitterly felt when too late.

But one main help, we are persuaded, is to be found in studying - and by this we do not mean the mere reading, but the digging into and through, the energizing upon, and mastering-such books as we have mentioned at the close of this paper. These are not, of course, the only works we would recom- 
mend to those who wish to understand thoroughly, and to make up their minds, on these great subjects as wholes; but we all know too well that our Art is long, broad, and deep,-and Time, opportunity, and our little hour, brief and uncertain, therefore, we would recommend those books as a sort of game of the mind, a mental exercise - like cricket, a gymnastic, a clearing of the eyes of their mind as with euphrasy, a strengthening their power over particulars, a getting fresh, strong views of worn out, old things, and, above all, a learning the right use of their reason, and by knowing their own ignorance and weakness, finding true knowledge and strength. Taking up a book like Arnauld, and reading a chapter of his lively, manly sense, is like throwing your manuals, and scalpels, and microscopes, and natural (most unnatural) orders out of your hand and head, and taking a game with the Grange Club, or a run to the top of Arthur Seat. Exertion quickens your pulse, expands your lungs, makes your blood warmer and redder, fills your mouth with the pure waters of relish, strengthens and supples your legs; and though on your way to the top you may encounter rocks, and baffling débris, and gusts of fierce winds rushing out upon you from behind corners, just as you will find in Arnauld, and all truly serious and honest books of the kind, difficulties and puzzles, winds of doctrine, and deceitful mists; still you are 
rewarded at the top by the wide view. You see, as from a tower, the end of all. You look into the perfections and relations of things. You see the clouds, the bright lights, and the everlasting hills on the far horizon. You come down the hill a happier, a better, and a hungrier man, and of a better mind. But, as we said, you must eat the book, you must crush it, and cut it with your teeth and swallow it; just as you must walk up, and not be carried up the hill, much less imagine you are there, or look upon a picture of what you would see were you up, however accurately or artistically done; no-you yourself must do both.

Philosophy - the love and the possession of wisdom-is divided into two things, science or knowledge; and a habit, or power of mind. $\mathrm{He}$ who has got the first is not truly wise unless his mind has reduced and assimilated it, as Dr. Prout would have said, unless he appropriates and can use it or his need.

The prime qualifications of a physician may be summed up in the words Capax, Perspicax, Sagax, Efficax. Capax - there must be room to receive, and arrange, and keep knowledge; Perspicaxsenses and perceptions, keen, accurate, and immediate, to bring in materials from all sensible things; Sagax - a central power of knowing what is what, and what it is worth, of choosing and rejecting, of 
judging; and finally, Efficax - the will and the way - the power to turn all the other three-capacity, perspicacity, sagacity, to account, in the performance of the thing in hand, and thus rendering back to the outer world, in a new and useful form, what you had received from it. These are the intellectual qualities which make up the physician, without any one of which he would be mancus, and would not deserve the name of a complete artsman, any more than proteine would be itself if any one of its four elements were amissing.

We have left ourselves no room to speak of the books we have named at the end of this paper. We recommend them all to our young readers. Arnauld's excellent and entertaining Art of Thinking - the once famous Port-Royal Logic — is, if only one be taken, probably the best. Thomson's little book is admirable, and is specially suited for a medical student, as its illustrations are drawn with great intelligence and exactness from chemistry and physiology. We know nothing more perfect than the analysis, at page 348 , of Sir $H$. Davy's beautiful experiments to account for the traces of an alkali, found when decomposing water by galvanism. It is quite exquisite, the hunt after and the unearthing of 'the residual cause.' This book has the great advantage of a clear, lively, and strong style. We can only give some short extracts. 
'We may define the inductive method as the process of discovering laws and rules from facts, and causes from effects: and the deductive, as the method of deriving facts from laws, and effects from their causes.'

There is a valuable paragraph on anticipation and its uses - there is a power and desire of the mind to project itself from the known into the unknown, in the expectation of finding what it is in search of.

'This power of divination, this sagacity, which is the mother of all science, we may call anticipation. The intellect, with a dog-like instinct, will not hunt until it has found the scent. It must have some presage of the result before it will turn its energies to its attainment. The system of anatomy which has immortalized the name of Oken, is the consequence of a flash of anticipation, which glanced through his mind when he picked up, in a chance walk, the skull of a deer, bleached by the weather, and exclaimed - "It is a vertebral column!",

'The man of science possesses principles - the man of art, not the less nobly gifted, is possessed and carried away by them. The principles which art involves, science evolves. The truths on which the success of art depends lurk in the artist's mind in an undeveloped state, guiding his hand, stimu- 
lating his invention, balancing his judgment, but not appearing in regular propositions.' 'An art (that of medicine for instance) will of course admit into its limits, everything (and nothing) else which can conduce to the performance of its own proper work; it recognises no other principles of selection.'

'He who reads a book on logic, probably thinks no better when he rises up than when he sat down, but if any of the principles there unfolded cleave to his memory, and he afterwards, perhaps unconsciously, shapes and corrects his thoughts by them, no doubt the whole powers of his reasoning receive benefit. In a word, every art, from reasoning to riding and rowing, is learned by assiduous practice, and if principles do any good, it is proportioned to the readiness with which they can be converted into rules, and the patient constancy with which they are applied in all our attempts at excellence.'

'A man can teach names to another man, but he cannot plant in another's mind that far higher giftthe power of naming.'

'Language is not only the vehicle of thought, it is a great and efficient instrument in thinking.'

'The whole of every science may be made the subject of teaching. Not so with art; much of it is not teachable.'

Coleridge's profound and brilliant, but unequal, 
and often somewhat nebulous Essay on Method, is worth reading over, were it only as an exercitation, and to impress on the mind the meaning and value of method. Method is the road by which you reach, or hope to reach, a certain end; it is a process. It is the best direction for the search after truth. System, again, which is often confounded with it, is a mapping out, a circumscription of knowledge, either already gained, or theoretically laid down as probable. Aristotle had a system which did much good, but also much mischief. Bacon was chiefly occupied in preparing and pointing out the waythe only way-of procuring knowledge. He left to others to systematize the knowledge after it was got; but the pride and indolence of the human spirit lead it constantly to build systems on imperfect knowledge. It has the trick of filling up out of its own fancy what it has not the diligence, the humility, and the honesty, to seek in nature; whose servant, and articulate voice, it ought to be.

Descartes' little tract on Method is, like everything the lively and deep-souled Breton did, full of original and bright thought.

Sir John Herschel's volume needs no praise. We know no work of the sort, fuller of the best moral worth, as well as the highest philosophy. We fear it is more talked of than read.

We would recommend the article in the Quarterly 
Review as first-rate, and written with great eloquence and grace.

Sydney Surth's Sketches of Lectures on Moral Philosophy. Second Edition.

SEDGwick's Discourse on the Studies at Cambridge, with a Preface and Appendix. Sixth Edition.

We have put these two worthies here, not because we had forgotten them,-much less because we think less of them than the others, especially Sydney; but because we bring them in at the end of our small entertainment, as we hand round a liqueurbe it Curaçoa, Kimmel, or old Glenlivet - after dinner, and end with the heterogeneous plum-pudding, that most English of realized ideas. Sydney Smith's book is one of rare excellence, and well worthy of the study of men and women, though perhaps not transcendental enough for our modern philosophers, male and female. It is really astonishing how much of the best of everything, from patriotism to nonsense, is to be found in this volume of sketches. You may read it through, if your sides can bear such an accumulation of laughter, with great benefit; and if you open it anywhere, you can't read three sentences without coming across some, it may be common thought, and often original enough, better expressed and put than you ever before saw it. 
The lectures on the Affections, the Passions and Desires, and on Study, we would have everybody to read and enjoy.

Sedgwick is a different, and, as a whole, an inferior man; but a man every inch of him, and an Englishman too, in his thoughts, and in his fine mother wit and tongue. He has, in the midst of all his confusion and passionateness, the true instinct of philosophy-the true venatic sense of objective truth. We know nothing better in the main, than his demolition of what is untrue, and his reduction of what is absurd, and his taking the wind out of what is tympanitic, in the notorious Vestiges; we don't say he always does justice to what is really good in it; his mission is to execute justice upon it, and that he does. His remarks on Oken and Owen, and his quotations from Dr. Clarke's admirable paper on the Development of the Fotus, in the Cambridge Philosophical Iransactions, we would recommend to our medical friends. The very confusion of Sedgwick is the free outcome of a deep and racy nature ; it puts us in mind of what happened, when an Englishman was looking with astonishment and disgust at a Scotchman eating a singed sheep's head, and was asked by the eater what he thought of that dish? 'Dish, Sir, do you call that a dish?' 'Dish or no dish,' rejoined the Caledonian, 'there's a deal o' fine confused feedin' aboot it, let me tell you.' 
We conclude these rambling remarks with a quotation from Arnauld, the friend of Pascal, and the intrepid antagonist of the Vatican and the Grand Monarque; one of the noblest, freest, most untiring and honest intellects our world has ever seen. "Why don't you rest sometimes?' said his friend Nicole to him. 'Rest! why should I rest here? haven't I an eternity to rest in?' The following sentence from his Port-Royal Logic, so well introduced and translated by Mr. Baynes, contains the gist of all we have been trying to say. It should be engraven on the tablets of every young student's heart-for the heart has to do with study as well as the head.

'There is nothing more desirable than good sense and justness of mind,-all other qualities of mind are of limited use, but exactness of judgment is of general utility in every part and in all employments of life.

' We are too apt to employ reason merely as an instrument for acquiring the sciences, whereas we ought to avail ourselves of the sciences, as an instrument for perfecting our reason; justness of mind being infinitely more important than all the speculative knowledge which we can obtain by means of sciences the most solid. This ought to lead wise men to make their sciences the exercise and not the occupation of their mental powers. Men are not born to employ all their time in measuring lines, in considering the 
various movements of matter: their minds are 100 great, and their lives too short, their time too precious, to be so engrossed; but they are born to be just, equitable, and prudent, in all their thoughts, their actions, their business; to these things they ought especially to train and discipline themselves.'

So, young friends, bring Brains to your work, and mix everything with them, and them with everything. Arma virumque, tools and a man to use them. Stir up, direct, and give free scope to Sir Joshua's 'that,' and try again, and again ; and look, oculo intento, acie acerrimâ. Looking is a voluntary act,- it is the man within coming to the window ; seeing is a state,-passive and receptive, and, at the best, little more than registrative.

Since writing the above, we have read with great satisfaction Dr. Forbes's Lecture delivered before the Chichester Literary Society and Mechanics' Institute, and published at their request. Its subject is, Happiness in its relation to Work and Knowledge. It is worthy of its author, and is, we think, more largely and finely embued with his personal character, than any one other of his works that we have met with. We could not wish a fitter present for a young man starting on the game of life. It is a wise, cheerful, manly, and warm-hearted discourse on the words of Bacon,- ' He that is wise, let him pursue some desire or other; for he that doth not 
affect some one thing in chief, unto him all things are distasteful and tedious.' We will not spoil this little volume by giving any account of it. Let our readers get it, and read it. The extracts from his Thesis, De Mentis Exercitatione et Felicitate exinde derivandâ, are very curious - showing the native vigour and bent of his mind, and indicating also, at once the identity and the growth of his thoughts during the lapse of thirty-three years.

We give the last paragraph, the sense and the filial affection of which are alike admirable. Having mentioned to his hearers that they saw in himself a living illustration of the truth of his position -that happiness is a necessary result of knowledge and work, he thus concludes :-

'If you would further desire to know to what besides I am chiefly indebted for so enviable a lot, I would say:- - Ist, Because I had the good fortune to come into the world with a healthful frame, and with a sanguine temperament. $2 \mathrm{~d}$, Because I had no patrimony, and was therefore obliged to trust to my own exertions for a livelihood. $3 \mathrm{~d}$, Because I was born in a land where instruction is greatly prized and readily accessible. 4th, Because I was brought up to a profession which not only compelled mental exercise, but supplied for its use materials of the most delightful and varied kind. And lastly and principally, because the good man to whom I owe my exist- 
ence, had the foresight to know what would be best for his children. He had the wisdom, and the courage, and the exceeding love, to bestow all that could be spared of his worldly means, to purchase for his sons that which is beyond price, EDUCATION; well judging that the means so expended, if hoarded for future use, would be, if not valueless, certainly evanescent, while the precious treasure for which they were exchanged, a cultivated and instructed mind, would not only last through life, but might be the fruitful source of treasures far more precious than itself. So equipped he sent them forth into the world to fight Life's battle, leaving the issue in the hand of God; confident, however, that though they might fail to achieve renown or to conquer Fortune, they possessed that which, if rightly used, could win for them the yet higher prize of HAPPINESS.'

Since this was written, many good books have appeared, but we would select three, which all young men should read and get-Hartley Coleridge's Lives of Northern Worthics, Thackeray's Letters of Broum the Elder, and Tom Brown's Schooldays - in spirit and expression, we don't know any better models for manly courage, good sense, and feeling, and they are as well written as they are thought.

There are the works of another man, one of the 
greatest, not only of our, but of any time, to which we cannot too earnestly draw our young readers. We mean the philosophical writings of Sir William Hamilton. We know no more invigorating, quickening, rectifying kind of exercise, than reading with a will, anything he has written upon permanently important subjects. There is a greatness and simplicity, a closeness of thought, a glance keen and wide, a play of the entire nature, and a truthfulness and downrightness, with an amount, and accuracy, and vivification of learning, such as we know of in no one other writer, ancient or modern-not even Leibnitz; and we know no writings which so wholesomely at once exalt and humble the reader, make him feel what is in him, and what he can and may, as well as what he cannot, and need never hope to know. In this respect, Hamilton is as grand as Pascal, and more simple; he exemplifies everywhere his own sublime adaptation of Scripture-unless a man become a little child, he cannot enter into the kingdom; he enters the temple stooping, but he presses on, intrepid and alone, to the inmost adytum, worshipping the more the nearer he gets to the inaccessible shrine, whose veil no mortal hand has ever rent in twain. And we name after him, the thoughtful, candid, impressive little volume of his pupil, his friend, and his successor, Professor Fraser.

The following passage from Sir William Hamil- 
ton's Dissertations, besides its wise thought, sounds in the ear like the pathetic and majestic sadness of a symphony by Beethoven :-

'There are two sorts of ignorance: we philosophize to escape ignorance, and the consummation of our philosophy is ignorance; we start from the one, we repose in the other; they are the goals from which, and to which, we tend; and the pursuit of knowledge is but a course between two ignorances as human life is itself only a travelling from grave to grave.

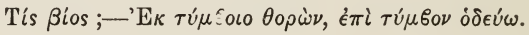

The highest reach of human science is the scientific recognition of human ignorance; "Qui nescit ignorare, ignorat scire." This "learned ignorance" is the rational conviction by the human mind of its inability to transcend certain limits; it is the knowledge of ourselves, - the science of man. This is accomplished by a demonstration of the disproportion between what is to be known, and our faculties of knowing, - the disproportion, to wit, between the infinite and the finite. In fact, the recognition of human ignorance is not only the one highest, but the one true, knowledge; and its first-fruit, as has been said, is humility. Simple nescience is not proud; consummated science is positively humble. For this knowledge it is not, which "puffeth up ;" but its 
opposite, the conceit of false knowledge,- -the conceit, in truth, as the apostle notices, of an ignorance of the very nature of knowledge :-

"Nam nesciens quid scire sit,

Te scire cuncta jactitas."

"But as our knowledge stands to Ignorance, so stands it also to Doubt. Doubt is the beginning and the end of our efforts to know ; for as it is true,"Alte dubitat qui altius credit," so it is likewise true, _."Quo magis quærimus magis dubitamus."

"The grand result of human wisdom is thus only a consciousness that what we know is as nothing to what we know not, ("Quantum est quod nescimus!") -an articulate confession, in fact, by our natural reason, of the truth declared in revelation, that " not" we see through a glass darkly.",

His pupil writes in the same spirit and to the same end:- 'A discovery, by means of reflection and mental experiment, of the limits of knowledge, is the highest and most universally applicable discovery of all; it is the one through which our intellectual life most strikingly blends with the moral and practical p part of human nature. Progress in knowledge is often paradoxically indicated by a diminution in the apparent bulk of what we know. Whatever helps to work off the dregs of false opinion, and to purify the intellectual mass-whatever deepens our conviction of our infinite ignorance-really adds to, although it 

4I 6
Hore Subsecive.

sometimes seems to diminish, the rational possessions of man. This is the highest kind of merit that is claimed for Philosophy by its earliest as well as by its latest representatives. It is by this standard that Socrates and Kant measure the chief results of their toil.'

\section{BOOKS REFERRED TO.}

I. Arnauld's Port-Royal Logic ; translated by T. S. Baynes. -2. Thomson's Outlines of the Necessary Laws of Thought. 3. Descartes on the Method of Rightly Conducting the Reason, and Seeking Truth in the Sciences. -4. Coleridge's Essay on Method. - 5. Whately's Logic and Rhetoric; new and cheap edition. -6. Mill's Logic ; new and cheap edition. -7. Dugald Stewart's Outlines. -8. Sir John Herschel's Preliminary Dissertation. -9. Quarterly Review, vol. lxviii. ; Article upon Whewell's Philosophy of Inductive Sciences. - IO. Isaac Taylor's Elements of Thought. - I I. Sir William Hamilton's edition of Reid ; Dissertations ; and Lectures.-I2. Professor Fraser's Rational Philosophy.-I3. Locke on the Conduct of the Understanding. 


\section{ARTHUR H. HALLAM.}

'PRASENs imperfectum, - perfectum, plusquam perfectum Futurum.'-Grotius.

' The idea of thy life shall sweetly creep

Into my study of imagination;

And every lovely organ of thy life

Shall come apparelled in more precious habit-.

More moving delicate, and full of life,

Into the eye and prospect of my sou?,

Than when thou livedst indeed.'

Much Ado about Nothing. 



\section{ARTHUR H. HALLAM.}

$\mathrm{I}^{\mathrm{N}}$ the chancel of Clevedon Church, Somersetshire, rest the mortal remains of Arthur Henry Hallam, eldest son of our great philosophic historian and critic,-and the friend to whom In Memoriam is sacred. This place was selected by his father, not only from the connexion of kindred, being the burial-place of his maternal grandfather, Sir Abraham Elton, but likewise 'on account of its still and sequestered situation, on a lone hill that overhangs the Bristol Channel.' 'That lone hill, with its humble old church, its outlook over the waste of waters, where 'the stately ships go on,' was, we doubt not, in Tennyson's mind, when the poem, 'Break, break, break,' which contains the burden of that volume in which are enshrined so much of the deepest affection, poetry, philosophy, and godliness, rose into his 'study of imagination'- ' into the eye and prospect of his soul.' 1

1 The passage from Shakspere prefixed to this paper, contains probably as much as can be said of the mental, not less 
'Break, break, break, On thy cold grey stones, O sea!

And I would that my tongue could utter The thoughts that arise in me.

' O well for the fisherman's boy, That he shouts with his sister at play!

O well for the sailor lad That he sings in his boat on the bay!

'And the stately ships go on

To their haven under the hill!

But $\mathrm{O}$ for the touch of a vanish'd hand, And the sound of a voice that is still !

than the affectionate conditions, under which such a record as In Memoriam is produced, and may give us more insight into the imaginative faculty's mode of working, than all our philosophizing and analysis. It seems to let out with the fulness, simplicity, and unconsciousness of a child-'Fancy's Child'the secret mechanism or procession of the greatest creative mind our race has produced. In itself, it has no recondite meaning, it answers fully its own sweet purpose. We are not believers, like some folks, in the omniscience of even Shakspere. But, like many things that he and other wise men and many simple children say, it has a germ of universal meaning, which it is quite lawful to bring out of it, and which may be enjoyed to the full without any wrong to its own original beauty and fitness. A dew-drop is not the less beautiful that it illustrates in its structure the law of gravitation which holds the world together, and by which 'the most ancient heavens are fresh and strong.' This is the passage. The Friar speaking of Claudio, hearing that Hero 'died upon his words,' says-

\footnotetext{
'The idea of her life shall sweetly creep

Into his study of imagination ;

And every lovely organ of her life

Shall come apparelled in more precious habit-

More moving delicate, and full of life,

Into the eye and prospect of his soul,

Than when she lived indeed.'
} 
'Break, break, break,

At the foot of thy crags, O sea!

But the tender grace of a day that is dead

Will never come back to me.'

Out of these few simple words, deep and melancholy, and sounding as the sea, as out of a well of the living waters of love, flows forth all In Memoriam, as a stream flows out of its spring - all is here. 'I would that my tongue could utter the thoughts that arise in me,' — 'the touch of the

We have here expressed in plain language the imaginative memory of the beloved dead, rising upon the past, like moonlight upon midnight,-

'The gleam, the shadow, and the peace supreme.'

This is its simple meaning-the statement of a truth, the utterance of personal feeling. But observe its hidden abstract significance-it is the revelation of what goes on in the depths of the soul, when the dead elements of what once was, are laid before the imagination, and so breathed upon as to be quickened into a new and higher life. We have first the Idea of her Life-all he remembered and felt of her, gathered into one vague shadowy image, not any one look, or action, or time, - then the idea of her life creeps-is in before he is aware, and sweETLy creepsit might have been softly or gently, but it is the addition of affection to all this, and bringing in another sense, - and now it is in his study of imagination-what a place! fit for such a visitor. Then out comes the Idea, more particular, more questionable, but still ideal, spiritual-every lovely organ of her lifethen the clothing upon, the mortal putting on its immortal, spiritual body-shall come apparelled in more precious habit, more moving delicate - this is the transfiguring, the putting on strength, the poco più - the little more which makes immortal, - more full of life, and all this submitted to-the eye and prospect of the soul. 
vanished hand-the sound of the voice that is still,' - the body and soul of his friend. Rising as it were out of the midst of the gloom of the valley of the shadow of death,

'The mountain infant to the sun comes forth Like human life from darkness ;'

and how its waters flow on! carrying life, beauty, magnificence,--shadows and happy lights, depths of blackness, depths clear as the very body of heaven. How it deepens as it goes, involving larger interests, wider views, 'thoughts that wander through eternity,' greater affections, but still retaining its pure living waters, its unforgotten burden of love and sorrow. How it visits every region! ' the long unlovely street,' pleasant villages and farms, ' the placid ocean-plains,' waste howling wildernesses, grim woods, nemorumque noctem, informed with spiritual fears, where may be seen, if shapes they may be called-

- Fear and trembling Hope,

Silence and Foresight; Death the Skeleton, And Time the Shadow ;'

now within hearing of the Minster clock, now of the College bells, and the vague hum of the mighty city. And over head through all its course the heaven with its clouds, its sun, moon, and stars ; but always, and in all places, declaring its source; and even when laying its burden of manifold and faithful 
affection at the feet of the Almighty Father, still remembering whence it came,

- That friend of mine who lives in God, That God which ever lives and loves; One God, one law, one element, And one far-off divine event, To which the whole creation moves.'

It is to that chancel, and to the day, $3 \mathrm{~d}$ January I834, that he refers in poem xviII. of In Memoriam.

' 'Tis well, 'tis something, we may stand

Where he in English earth is laid, And from his ashes may be made The violet of his native land.

' 'Tis little ; but it looks in truth As if the quiet bones were blest Among familiar names to rest, And in the places of his youth.'

And again in XIX. :

' The Danube to the Severn gave The darken'd heart that beat no more ;

They laid him by the pleasant shore, And in the hearing of the wave.

' There twice a day the Severn fills, The salt sea-water passes by, And hushes half the babbling Wye, And makes a silence in the hills.'

Here, too, it is, Lxvi. :

' When on my bed the moonlight falls,

I know that in thy place of rest,

By that broad water of the west ;

There comes a giory on the walls : 
' Thy marble bright in dark appears, As slowly steals a silver flame Along the letters of thy name, And o'er the number of thy years.'

This young man, whose memory his friend has consecrated in the hearts of all who can be touched by such love and beauty, was in nowise unworthy of all this. It is not for us to say, for it was not given to us the sad privilege to know, all that a father's heart buried with his son in that grave, all ' the hopes of unaccomplished years ;' nor can we feel in its fulness all that is meant by

\section{' Such}

A friendship as had mastered Time;

Which masters Time indeed, and is

Eternal, separate from fears.

The all-assuming months and years

Can take no part away from this.'

But this we may say, we know of nothing in all literature to compare with the volume from which these lines are taken, since David lamented with this lamentation: "The beauty of Israel is slain. Ye mountains of Gilboa, let there be no dew, neither rain upon you. I am distressed for thee, my brother Jonathan : very pleasant hast thou been unto me; thy love for me was wonderful.' We cannot, as some have done, compare it with Shakspere's sonnets, or with Lycidas. In spite of the amazing genius and tenderness, the never-wearying, all-involving reiteration of passionate attachment, the idolatry 


\section{Arthur H. Hallam.}

of admiring love, the rapturous devotedness, displayed in these sonnets, we cannot but agree with Mr. Hallam in thinking 'that there is a tendency now, especially among young men of poetical tempers, to exaggerate the beauties of these remarkable productions;' and though we would hardly say with him, 'that it is impossible not to wish that Shakspere had never written them,' giving us, as they do, and as perhaps nothing else could do, such proof of a power of loving, of an amount of attendrissement, which is not less wonderful than the bodying forth of that myriad-mind which gave us Hamlet, and Lear, Cordelia, and Puck, and all the rest, and indeed explaining to us how he could give us all these ;while we hardly go so far, we agree with his other wise words :- 'There is a weakness and folly in all misplaced and excessive affection;' which in Shakspere's case is the more distressing, when we consider that 'Mr. W. H., the only begetter of these ensuing sonnets,' was, in all likelihood, William Herbert, Ear\} of Pembroke, a man of noble and gallant character, but always of licentious life.

As for Lycidas, we must confess that the poetryand we all know how consummate it is-and not the affection, seems uppermost in Milton's mind, as it is in ours. The other element, though quick and true, has no glory through reason of the excellency of that which invests it. But there is no such drawback in 
In Memoriam. The purity, the temperate but fervent goodness, the firmness and depth of nature, the impassioned logic, the large, sensitive, and liberal heart, the reverence and godly fear, of

'That friend of mine who lives in God,'

which from these Remains we know to have dwelt in that young soul, give to In Memoriam the character of exactest portraiture. There is no excessive or misplaced affection here; it is all founded in fact : while everywhere and throughout it all, affectiona love that is wonderful-meets us first and leaves us last, giving form and substance and grace, and the breath of life and love, to everything that the poet's thick-coming fancies so exquisitely frame. We can recall few poems approaching to it in this quality of sustained affection. The only English poems we can think of as of the same order, are Cowper's lines on seeing his mother's portrait :-

' $O$ that these lips had language!'

Burns to 'Mary in Heaven;' and two pieces of Vaughan-one beginning

'O thou who know'st for whom I mourn;'

and the other-

'They are all gone into the world of light.'

But our object now is, not so much to illustrate Mr. Tennyson's verses, as to introduce to our readers, what we ourselves have got so much delight, and, 


\section{Arthur H. Hallam.}

we trust, profit from-The Remains in Verse and Prose, of Arthur Henry Hallam, I834; privately printed. We had for many years been searching for this volume, but in vain; a sentence quoted by Henry Taylor struck us, and our desire was quickened by reading In Memoriam. We do not remember when we have been more impressed than by these Remains of this young man, especially when taken along with his friend's Memorial ; and instead of trying to tell our readers what this impression is, we have preferred giving them as copious extracts as our space allows, that they may judge and enjoy for themselves. The italics are our own. We can promise them few finer, deeper, and better pleasures than reading, and detaining their minds over these two books together, filling their hearts with the fulness of their truth and tenderness. They will see how accurate as well as how affectionate and 'of imagination all compact' Tennyson is, and how worthy of all that he has said of him, that friend was. The likeness is drawn ad vivum,

"When to the sessions of sweet silent thought He summons up remembrance of things past.'

'The idea of his Life' has been sown a natural body, and has been raised a spiritual body, but the identity is unhurt; the countenance shines and the raiment is white and glistering, but it is the same face and form. 
The Memoir is by Mr. Hallam. We give it entire, not knowing anywhere a nobler or more touching record of a father's love and sorrow.

'Arthur Henry Hallam was born in Bedford Place, ${ }^{1}$ London, on the Ist of February I8II. Very few years had elapsed before his parents observed strong indications of his future character, in a peculiar clearness of perception, a facility of acquiring knowledge, and, above all, in an undeviating sweetness of disposition, and adherence to his sense of what was right and becoming. As he advanced to another stage of childhood, it was rendered still more manifest that he would be distinguished from ordinary persons, by an increasing thoughtfulness, and a fondness for a class of books, which in general are so little intelligible to boys of his age, that they excite in them no kind of interest.

"In the summer of 1818 he spent some months with his parents in Germany and Switzerland, and became familiar with the French language, which

1 ' Dark house, by which once more I stand Here in the long unlovely street;

Doors, where my heart was wont to beat So quickly, waiting for a hand.'

\section{In Memoriam.}

This is a mistake, as his friend Dr. A. P. Stanley thus corrects :- " "The long unlovely street" was Wimpole Street, No. 67, where the Hallams lived ; and Arthur used to say to his friends, "You know you will always find us at sixes and sevens.", 
he had already learned to read with facility. $\mathrm{He}$ had gone through the elements of Latin before this time; but that language having been laid aside during his tour, it was found upon his return that, a variety of new scenes having effaced it from his memory, it was necessary to begin again with the first rudiments. He was nearly eight years old at this time; and in little more than twelve months he could read Latin with tolerable facility. In this period his mind was developing itself more rapidly than before; he now felt a keen relish for dramatic poetry, and wrote several tragedies, if we may so call them, either in prose or verse, with a more precocious display of talents than the Editor remembers to have met with in any other individual. The natural pride, however, of his parents, did not blind them to the uncertainty that belongs to all premature efforts of the mind; and they so carefully avoided everything like a boastful display of blossoms which, in many cases, have withered away in barren luxuriance, that the circumstance of these compositions was hardly ever mentioned out of their own family.

'In the spring of 1820 , Arthur was placed under the Rev. W. Carmalt, at Putney, where he remained nearly two years. After leaving this school, he went abroad again for some months; and, in October 1822 , became the pupil of the Rev. E. C. Hawtrey, 
an Assistant Master of Eton College. At Eton he continued till the summer of I827. He was now become a good though not perhaps a first-rate scholar in the Latin and Greek languages. The loss of time, relatively to this object, in travelling, but far more his increasing avidity for a different kind of knowledge, and the strong bent of his mind to subjects which exercise other faculties than such as the acquirement of languages calls into play, will sufficiently account for what might seem a comparative deficiency in classical learning. It can only, however, be reckoned one, comparatively to his other attainments, and to his remarkable facility in mastering the modern languages. The Editor has thought it not improper to print in the following pages an Eton exercise, which, as written before the age of fourteen, though not free from metrical and other errors, appears, perhaps to a partial judgment, far above the level of such compositions. It is remarkable that he should have selected the story of Ugolino, from a poet with whom, and with whose language, he was then but very slightly acquainted, but who was afterwards to become, more perhaps than any other, the master-mover of his spirit. It may be added, that great judgment and taste are perceptible in this translation, which is by no means a literal one ; and in which the phraseology of Sophocles is not ill substituted, in some passages, for that of Dante. 
'The Latin poetry of an Etonian is generally reckoned at that School the chief test of his literary talent. That of Arthur was good without being excellent; he never wanted depth of thought, or truth of feeling; but it is only in a few rare instances, if altogether in any, that an original mind has been known to utter itself freely and vigorously, without sacrifice of purity, in a language the capacities of which are so imperfectly understood; and in his productions there was not the thorough conformity to an ancient model which is required for perfect elegance in Latin verse. He took no great pleasure in this sort of composition; and perhaps never returned to it of his own accord.

'In the latter part of his residence at Eton, he was led away more and more by the predominant bias of his mind, from the exclusive study of ancient literature. The poets of England, especially the older dramatists, came with greater attraction over his spirit. He loved Fletcher, and some of Fletcher's contemporaries, for their energy of language and intenseness of feeling; but it was in Shakspere alone that he found the fulness of soul which seemed to slake the thirst of his own rapidly expanding genius for an inexhaustible fountain of thought and emotion. He knew Shakspere thoroughly; and indeed his acquaintance with the earlier poetry of this country was very extensive. 
Among the modern poets, Byron was at this time, far above the rest, and almost exclusively, his favourite; a preference which, in later years, he transferred altogether to Wordsworth and Shelley.

' $\mathrm{He}$ became, when about fifteen years old, a member of the debating society established among the elder boys, in which he took great interest; and this served to confirm the bias of his intellect towards the moral and political philosophy of modern times. It was probably, however, of important utility in giving him that command of his own language which he possessed, as the following Essays will show, in a very superior degree, and in exercising those powers of argumentative discussion, which now displayed themselves as eminently characteristic of his mind. It was a necessary consequence that he declined still more from the usual paths of study, and abated perhaps somewhat of his regard for the writers of antiquity. It must not be understood, nevertheless, as most of those who read these pages will be aware, that he ever lost his sensibility to those ever-living effusions of genius which the ancient languages preserve. He loved Eschylus and Sophocles (to Euripides he hardly did justice), Lucretius and Virgil; if he did not seem so much drawn towards Homer as might 'at first be expected, this may probably be accounted for by his increasing taste for philosophical poetry. 
'In the early part of 1827 , Arthur took a part in the Eton Miscellany, a periodical publication, in which some of his friends in the debating society were concerned. He wrote in this, besides a few papers in prose, a little poem on a story connected with the Lake of Killarney. It has not been thought by the Editor advisable, upon the whole, to reprint these lines; though, in his opinion, they bear very striking marks of superior powers. This was almost the first poetry that Arthur had written, except the childish tragedies above mentioned. No one was ever less inclined to the trick of versifying. Poetry with him was not an amusement, but the natural and almost necessary language of genuine emotion; and it was not till the discipline of serious reflection, and the approach of manhood, gave a reality and intenseness to such emotions, that he learned the capacities of his own genius. That he was a poet by nature, these Remains will sufficiently prove; but certainly he was far removed from being a versifier by nature; nor was he probably able to perform, what he scarce ever attempted, to write easily and elegantly on an ordinary subject. The lines on the story of Pygmalion are so far an exception, that they arose out of a momentary amusement of society; but he could not avoid, even in these', his own grave tone of poetry.

' Upon leaving Eton in the summer of 1827 , he 
accompanied his parents to the Continent, and passed eight months in Italy. This introduction to new scenes of nature and art, and to new sources of intellectual delight, at the very period of transition from boyhood to youth, sealed no doubt the peculiar character of his mind, and taught him, too soon for his peace, to sound those depths of thought and feeling, from which, after this time, all that he wrote was derived. He had, when he passed the Alps, only a moderate acquaintance with the Italian language ; but during his residence in the country he came to speak it with perfect fluency, and with a pure Sienese pronunciation. In its study he was much assisted by his friend and instructor, the Abbate Pifferi, who encouraged him to his first attempts at versification. The few sonnets, which are now printed, were, it is to be remembered, written by a foreigner, hardly seventeen years old, and after a very short stay in Italy. The Editor might not, probably, have suffered them to appear even in this private manner, upon his own judgment. But he knew that the greatest living writer of Italy, to whom they were shown some time since at Milan, by the author's excellent friend, Mr. Richard Milnes, has expressed himself in terms of high approbation.

'The growing intimacy of Arthur with Italian poetry led him naturally to that of Dante. No poet was so congenial to the character of his own 


\section{Arthur H. Hallam.}

reflective mind; in none other could he so abur. lantly find that disdain of flowery redundance, that perpetual preference of the sensible to the ideal, that aspiration for somewhat better and less fleeting than earthly things, to which his inmost soul responded. Like all genuine worshippers of the great Florentine poet, he rated the Inferno below the two latter portions of the Dirina Commedia; there was nothing even to revolt his taste, but rather much to attract it, in the scholastic theology and mystic visions of the Paradiso. Petrarch he greatly admired, though with less idolatry than Dante; and the sonnets here printed will show to all competent judges how fully he had imbibed the spirit, without servile centonism, of the best writers in that style of composition who flourished in the sixteenth century.

'But poetry was not an absorbing passion at this time in his mind. His eyes were fixed on the best pictures with silent intense delight. He had a deep and just perception of what was beautiful in this art, at least in its higher schools; for he did not pay much regard, or perhaps quite do justice, to the masters of the seventeenth century. To technical criticism he made no sort of pretension; painting was to him but the visible language of emotion; and where it did not aim at exciting it, or employed inadequate means, his admiration would be withheld. Hence he highly prized the ancient paintings, both 
Italian and German, of the age which preceded the full development of art. But he was almost as enthusiastic an admirer of the Venetian, as of the Tuscan and Roman schools; considering these masters as reaching the same end by the different agencies of form and colour. This predilection for the sensitive beauties of painting is somewhat analogous to his fondness for harmony of verse, on which he laid more stress than poets so thoughtful are apt to do. In one of the last days of his life, he lingered long among the fine Venetian pictures of the Imperial Gallery at Vienna.

'He returned to England in June 1828 ; and, in the following October, went down to reside at Cambridge; having been entered on the boards of Trinity College before his departure to the Continent. He was the pupil of the Rev. William Whewell. In some respects, as soon became manifest, he was not formed to obtain great academical reputation. An acquaintance with the learned languages, considerable at the school where he was educated, but not improved, to say the least, by the intermission of a year, during which his mind had been so occupied by other pursuits, that he had thought little of antiquity even in Rome itself, though abundantly sufficient for the gratification of taste and the acquisition of knowledge, was sure to prove inadequate to the searching scrutiny of modern 
examinations. He soon, therefore, saw reason to renounce all competition of this kind; nor did he ever so much as attempt any Greek or Latin composition during his stay at Cambridge. In truth he was very indifferent to success of this kind; and conscious as he must have been of a high reputation among his contemporaries, he could not think that he stood in need of any University distinctions. The Editor became by degrees almost equally indifferent to what he perceived to be so uncongenial to Arthur's mind. It was however to be regretted, that he never paid the least attention to mathematical studies. That he should not prosecute them with the diligence usual at Cambridge, was of course to be expected; yet his clearness and acumen would certainly have enabled him to master the principles of geometrical reasoning; nor, in fact, did he so much find a difficulty in apprehending demonstrations, as a want of interest, and a consequent inability to retain them in his memory. A little more practice in the strict logic of geometry, a little more familiarity with the physical laws of the universe, and the phenomena to which they relate, would possibly have repressed the tendency to vague and mystical speculations which he was too fond of indulging. In the philosophy of the human mind, he was in no danger of the materializing theories of some ancient and modern schools; but in shunning this extreme, 
he might sometimes forget that, in the honest pursuit of truth, we can shut our eyes to no real phenomena, and that the physiology of man must always enter into any valid scheme of his psychology.

'The comparative inferiority which he might show in the usual trials of knowledge, sprung in a great measure from the want of a prompt and accurate memory. It was the faculty wherein he shone the least, according to ordinary observation; though his very extensive reach of literature, and his rapidity in acquiring languages, sufficed to prove that it was capable of being largely exercised. He could remember anything, as a friend observed to the Editor, that was associated with an idea. But he seemed, at least after he reached manhood, to want almost wholly the power, so common with inferior understandings, of retaining with regularity and exactness, a number of unimportant uninteresting particulars. It would have been nearly impossible to make him recollect for three days the date of the battle of Marathon, or the names in order of the Athenian months. Nor could he repeat poetry, much as he loved it, with the correctness often found in young men. It is not improbable, that a more steady discipline in early life would have strengthened this faculty, or that he might have supplied its deficiency by some technical devices; but where the higher powers of intellect were so extraordinarily mani- 


\section{Arthur H. Hallam.}

fested, it would have been preposterous to complain of what may perhaps have been a necessary consequence of their amplitude, or at least a natural result of their exercise.

'But another reason may be given for his deficiency in those unremitting labours which the course of academical education, in the present times, is supposed to exact from those who aspire to its distinctions. In the first year of his residence at Cambridge, symptoms of disordered health, especially in the circulatory system, began to show themselves; and it is by no means improbable, that these were indications of a tendency to derangement of the vital functions, which became ultimately fatal. A too rapid determination of blood towards the brain, with its concomitant uneasy sensations, rendered him frequently incapable of mental fatigue. $\mathrm{He}$ had indeed once before, at Florence, been affected by symptoms not unlike these. His intensity of reflection and feeling also brought on occasionally a considerable depression of spirits, which had been painfully observed at times by those who watched him most, from the time of his leaving Eton, and even before. It was not till after several months that he regained a less morbid condition of mind and body. This same irregularity of circulation returned in the next spring, but was of less duration. During the third year 
of his Cambridge life, he appeared in much better health.

'In this year (I83I) he obtained the first college prize for an English declamation. The subject chosen by him was the conduct of the Indepnedent party during the civil war. This exercise was greatly admired at the time, but was never printed. In consequence of this success, it became incumbent on him, according to the custom of the college, to deliver an oration in the chapel immediately before the Christmas vacation of the same year. On this occasion he selected a subject very congenial to his own turn of thought and favourite study, the influence of Italian upon English literature. He had previously gained another prize for an English essay on the philosophical writings of Cicero. This essay is perhaps too excursive from the prescribed subject ; but his mind was so deeply imbued with the higher philosophy, especially that of Plato, with which he was very conversant, that he could not be expected to dwell much on the praises of Cicero in that respect.

'Though the bent of Arthur's mind by no means inclined him to strict research into facts, he was full as much conversant with the great features of ancient and modern history, as from the course of his other studies and the habits of his life it was possible to expect. He reckoned them, as great 


\section{Arthur H. Hallam.}

minds always do, the groundworks of moral and political philosophy, and took no pains to acquire any knowledge of this sort from which a principle could not be derived or illustrated. To some parts of English history, and to that of the French Revolution, he had paid considerable attention. He had not read nearly so much of the Greek and Latin historians as of the philosophers and poets. In the history of literary, and especially of philosophical and religious opinions, he was deeply versed, as much so as it is possible to apply that term at his age. The following pages exhibit proofs of an acquaintance, not crude or superficial, with that important branch of literature.

' His political judgments were invariably prompted by his strong sense of right and justice. These, in so young a person, were naturally rather fluctuating, and subject to the correction of advancing knowledge and experience. Ardent in the cause of those he deemed to be oppressed, of which, in one instance, he was led to give a proof with more of energy and enthusiasm than discretion, he was deeply attached to the ancient institutions of his country.

'He spoke French readily, though with less elegance than Italian, till from disuse he lost much of his fluency in the latter. In his last fatal tour in Germany, he was rapidly acquiring a readiness in 
the language of that country. The whole range of French literature was almost as familiar to him as that of England.

'The society in which Arthur lived most intimately, at Eton and at the University, was formed of young men, eminent for natural ability, and for delight in what he sought above all things, the knowledge of truth, and the perception of beauty. They who loved and admired him living, and who now revere his sacred memory, as of one to whom, in the fondness of regret, they admit of no rival, know best what he was in the daily commerce of life; and his eulogy should, on every account, better come from hearts, which, if partial, have been rendered so by the experience of friendship, not by the affection of nature.

'Arthur left Cambridge on taking his degree in January 1832. He resided from that time with the Editor in London, having been entered on the boards of the Inner Temple. It was greatly the desire of the Editor that he should engage himself in the study of the law; not merely with professional views, but as a useful discipline for a mind tor much occupied with habits of thought, which, ennobling and important as they were, could not but separate him from the everyday business of life, and might, by their excess, in his susceptible temperament, be productive of considerable mischief. 
He had, during the previous long vacation, read with the Editor the Institutes of Justinian, and the two works of Heineccius which illustrate them; and he now went through Blackstone's Commentaries, with as much of other law-books as, in the Editor's judgment, was required for a similar purpose. It was satisfactory at that time to perceive that, far from showing any of that distaste to legal studies which might have been anticipated from some parts of his intellectual character, he entered upon them not only with great acuteness, but considerable interest. In the month of October I 832 , he began to see the practical application of legal knowledge in the office of an eminent conveyancer, Mr. Walters of Lincoln's Inn Fields, with whom he continued till his departure from England in the following summer.

'It was not, however, to be expected, or even desired by any one who knew how to value him, that he should at once abandon those habits of study which had fertilized and invigorated his mind. But he now, from some change or other in his course of thinking, ceased in a great measure to write poetry, and expressed to more than one friend an intention to give it up. The instances after his leaving Cambridge were few. The dramatic scene between Raffaelle and Fiammetta was written in r 832 ; and about the same time he had a design to 
translate the Vita Nuova of his favourite Dante; a work which he justly prized, as the development of that immense genius, in a kind of autobiography, which best prepares us for a real insight into the Divine Comedy. He rendered accordingly into verse most of the sonnets which the Vita Nuova contains; but the Editor does not believe that he made any progress in the prose translation. These sonnets appearing rather too literal, and consequently harsh, it has not been thought worth while to print.

'In the summer of $\mathrm{I}_{322}$, the appearance of Professor Rosetti's Disquisizioni sullo spirito Antipapale, in which the writings of Arthur's beloved masters Dante and Petrarch, as well as most of the mediæval literature of Italy, were treated as a series of enigmas, to be understood only by a key that discloses a latent Carbonarism, a secret conspiracy against the religion of their age, excited him to publish his own Remarks in reply. It seemed to him the worst of poetical heresies to desert the Absolute, the Universal, the Eternal, the Beautiful and True, which the Platonic spirit of his literary creed taught him to seek in all the higher works of genius, in quest of some temporary historical allusion, which could be of no interest with posterity. Nothing however could be more alien from his courteous disposition than to abuse the license of controversy, or to treat with intentional disrespect a very in- 


\section{Arthur H. Hallam.}

genious person, who had been led on too far in pursuing a course of interpretation, which, within certain much narrower limits, it is impossible for any one conversant with history not to admit.

'A very few other anonymous writings occupied his leisure about this time. Among these were slight memoirs of Petrarch, Voltaire, and Burke, for the Gallery of Portraits, published by the Society for the Diffusion of Useful Knowledge. ${ }^{1}$ His time was however principally devoted, when not engaged at his office, to metaphysical researches, and to the history of philosophical opinions.

'From the latter part of his residence at Cambridge, a gradual but very perceptible improvement in the cheerfulness of his spirits gladdened his family and his friends ; intervals there doubtless were, when

1 We had read these lives, and had remarked them, before we knew whose they were, as being of rare merit. No one could suppose they were written by one so young. We give his estimate of the character of Burke. "The mind of this great man may perhaps be taken as a representation of the general characteristics of the English intellect. Its groundwork was solid, practical, and conversant with the details of business; but upon this, and secured by this, arose a superstructure of imagination and moral sentiment. He saw little, because it was painful to him to see anything, beyond the limits of the national character. In all things, while he deeply reverenced principles, he chose to deal with the concrete rather than with abstractions. He studied men rather than man.' The words in italics imply an insight into the deepest springs of human action, the conjunct causes of what we call character, such as few men of large experience can attain. 
the continual seriousness of his habits of thought, or the force of circumstances, threw something more of gravity into his demeanour; but in general he was animated and even gay, renewing or preserving his intercourse with some of those he had most valued at Eton and Cambridge. The symptoms of deranged circulation which had manifested themselves before, ceased to appear, or at least so as to excite his own attention; and though it struck those who were most anxious in watching him, that his power of enduring fatigue was not quite so great as from his frame of body and apparent robustness might have been anticipated, nothing gave the least indication of danger either to their eyes, or to those of the medical practitioners who were in the habit of observing him. An attack of intermittent fever, during the prevalent influenza of the spring of 1833 , may perhaps have disposed his constitution to the last fatal blow.'

To any one who has watched the history of the disease by which 'so quick this bright thing came to confusion,' and who knows how near its subject must often, perhaps all his life, have been to that eternity which occupied so much of his thoughts and desires, and the secrets of which were so soon to open on his young eyes, there is something very touching in this account. Such a state of health would enhance, and tend to produce, by the sensa- 
tions proper to such a condition, that habitual seriousness of thought, that sober judgment, and that tendency to look at the true life of things - that deep but gentle and calm sadness, and that occasional sinking of the heart, which make his noble and strong inner nature, his resolved mind, so much more impressive and endearing.

This feeling of personal insecurity-of life being ready to slip away - the sensation that this world and its on-goings, its mighty interests, and delicate joys, is ready to be shut up in a moment-this instinctive apprehension of the peril of vehement bodily enjoyment-all this would tend to make him 'walk softly,' and to keep him from much of the evil that is in the world, and would help him to live soberly, righteously, and godly, even in the bright and rich years of his youth. His power of giving himself up to the search after absolute truth, and the contemplation of Supreme goodness, must have been increased by this same organization. But all this delicate feeling, this fineness of sense, did rather quicken the energy and fervour of the indwelling soul-the $\tau i$ शє $\rho$ óv $\pi \rho \hat{\alpha} \gamma \mu \alpha$ that burned within. In the quaint words of Vaughan, it was ' manhood with a female eye.' These two conditions must, as we have said, have made him dear indeed. And by a beautiful law of life, having that organ out of which are the issues of life, under a sort of perpetual near- 
ness to suffering, and so liable to pain, he would be more easily moved for others-more alive to their pain-more filled with fellow-feeling.

' The Editor cannot dwell on anything later. Arthur accompanied him to Germany in the beginning of August. In returning to Vienna from Pesth, a wet day probably gave rise to an intermittent fever, with very slight symptoms, and apparently subsiding, when a sudden rush of blood to the head put an instantaneous end to his life on the $\mathbf{5}_{5}$ th of September I833. The mysteriousness of such a dreadful termination to a disorder generally of so little importance, and in this instance of the slightest kind, has been diminished by an examination which showed a weakness of the cerebral vessels, and a want of sufficient energy in the heart. Those whose eyes must long be dim with tears, and whose hopes on this side the tomb are broken down for ever, may cling, as well as they can, to the poor consolation of believing that a few more years would, in the usual chances of humanity, have severed the frail union of his graceful and manly form with the pure spirit that it enshrined.

'The remains of Arthur were brought to England, and interred on the $3 \mathrm{~d}$ of January 1834 , in the chancel of Clevedon Church, in Somersetshire, belonging to his maternal grandfather, Sir Abraham Elton, a place selected by the Editor, not only from 
the connexion of kindred, but on account of its still and sequestered situation, on a lone hill that overhangs the Bristol Channel.

'More ought perhaps to be said-but it is very difficult to proceed. From the earliest years of this extraordinary young man, his premature abilities were not more conspicuous than an almost faultless disposition, sustained by a more calm self-command than has often been witnessed in that season of life. The sweetness of temper which distinguished his childhood, became with the advance of manhood a habitual benevolence, and ultimately ripened into that exalted principle of love towards God and man, which animated and almost absorbed his soul during the latter period of his life, and to which most of the following compositions bear such emphatic testimony. He seemed to tread the earth as a spirit from some better world; and in bowing to the mysterious will which has in mercy removed him, perfected by so short a trial, and passing over the bridge which separates the seen from the unseen life, in a moment, and, as we may believe, without a moment's pang, we must feel not only the bereavement of those to whom he was dear, but the loss which mankind have sustained by the withdrawing of such a light.

'A considerable portion of the poetry contained in this volume was printed in the year 1830, and was intended by the author to be published together with 
the poems of his intimate friend, Mr. Alfred Tennyson. They were however withheld from publication at the request of the Editor. The poem of Timbuctoo was written for the University prize in 1829 , which it did not obtain. Notwithstanding its too great obscurity, the subject itself being hardly indicated, and the extremely hyperbolical importance which the author's brilliant fancy has attached to a nest of barbarians, no one can avoid admiring the grandeur of his conceptions, and the deep philosophy upon which he has built the scheme of his poem. This is however by no means the most pleasing of his compositions. It is in the profound reflection, the melancholy tenderness, and the religious sanctity of other effusions that a lasting charm will be found. A commonplace subject, such as those announced for academical prizes generally are, was incapable of exciting a mind which, beyond almost every other, went straight to the furthest depths that the human intellect can fathom, or from which human feelings can be drawn. Many short poems, of equal beauty with those here printed, have been deemed unfit even for the limited circulation they might obtain, on account of their unveiling more of emotion than, consistently with what is due to him and to others, could be exposed to view.

'The two succeeding essays have never been printed; but were read, it is believed, in a literary 
society at Trinity College, or in one to which he afterwards belonged in London. That entitled Theodicaa Novissima, is printed at the desire of some of his intimate friends. A few expressions in it want his usual precision; and there are ideas which he might have seen cause, in the lapse of time, to modify, independently of what his very acute mind would probably have perceived, that his hypothesis. like that of Leibnitz, on the origin of evil, resolves itself at last into an unproved assumption of its necessity. It has however some advantages, which need not be mentioned, over that of Leibnitz; and it is here printed, not as a solution of the greatest mystery of the universe, but as most characteristic of the author's mind, original and sublime, uniting, what is very rare except in early youth, a fearless and unblenching spirit of inquiry into the highest objects of speculation, with the most humble and reverential piety. It is probable that in many of his views on such topics he was influenced by the writings of Jonathan Edwards, with whose opinions on metaphysical and moral subjects, he seems generally to have concurred.

'The extract from a review of Tennyson's poems in a publication now extinct, the Englishman's Magazine, is also printed at the suggestion of a friend. The pieces that follow are reprints, and have been already mentioned in this Memoir.' 
We have given this Memoir almost entire, for the sake both of its subject and its manner-for what in it is the father's as well as for what is the son's. There is something very touching in the paternal composure, the judiciousness, the truthfulness, where truth is so difficult to reach through tears, the calm estimate and the subdued tenderness, the ever-rising but ever-restrained emotion; the father's heart throbs throughout.

We wish we could have given in full the letters from Arthur's friends, which his father has incorporated in the Memoir. They all bring out in different but harmonious ways, his extraordinary moral and intellectual worth, his rare beauty of character, and their deep affection.

The following extract from one seems to us very interesting:--'Outwardly I do not think there was anything remarkable in his habits, except an irregularity with regard to times and places of study, which may seem surprising in one whose progress in so many directions was so eminently great and rapid. He was commonly to be found in some friend's room, reading, or canvassing. I dare say he lost something by this irregularity, but less than perhaps one would at first imagine. I never saw him idle. He might seem to be lounging, or only amusing himself, but his mind was always active, and active for good. In fact, his energy and quickness of apprehension did 
not stand in need of outward aid.' There is much in this worthy of more extended notice. Such minds as his probably grow hest in this way, are best left to themselves, to glide on at their own sweet wills; the stream was too deep and clear, and perhaps too entirely bent on its own errand, to be dealt with or regulated by any art or device. The same friend sums up his character thus:-'I have met with no man his superior in metaphysical subtlety; no man his equal as a philosophical critic on works of taste; no man whose views on all subjects connected with the duties and dignities of humanity were more large and generous, and enlightened.' And all this said of a youth of twenty-hen nimium brevis avi decus et desiderium!

We have given little of his verse; and what we do give is taken at random. We agree entirely in his father's estimate of his poetical gift and art, but his mind was too serious, too thoughtful, too intensely dedicated to truth and the God of truth, to linger long in the pursuit of beauty; he was on his way to God, and could rest in nothing short of Him, otherwise he might have been a poet of genuine excellence.

"Dark, dark, yea, " irrecoverably dark," Is the soul's eye ; yet how it strives and battles Thorough th' impenetrable gloom to fix That master light, the secret truth of things, Which is the body of the infinite God!' 
' Sure, we are leaves of one harmonious bower, Fed by a sap that never will be scant, All-permeating, all-producing mind ; And in our several parcellings of doom We but fulfil the beauty of the whole, Oh, madness! if a leaf should dare complain Of its dark verdure, and aspire to be The gayer, brighter thing that wantons near.'

' Oh, blessing and delight of my young heart, Maiden, who wast so lovely, and so pure, I know not in what region now thou art, Or whom thy gentle eyes in joy assure. Not the old hills on which we gazed together,

Not the old faces which we both did love, Not the old books, whence knowledge we did gather, Not these, but others now thy fancies move.

I would I knew thy present hopes and fears, All thy companions with their pleasant talk, And the clear aspect which thy dwelling wears :

So, though in body absent, I might walk With thee in thought and feeling, till thy mood Did sanctify mine own to peerless good.'

'Alfred, I would that you beheld me now, Sitting beneath a mossy ivied wall On a quaint bench, which to that structure old Winds an accordant curve. Above my head Dilates immeasurable a wild of leaves, Seeming received into the blue expanse That vaults this summer noon.'

' Still here-thou hast not faded from my sight, Nor all the music round thee from mine ear; Still grace flows from thee to the brightening year, And all the birds laugh out in wealthier light. 
Still am I free to close my happy eyes,

And paint upon the gloom thy mimic form,

That soft white neck, that cheek in beauty warm,

And brow half hidden where yon ringlet lies :

With, oh ! the blissful knowledge all the while

That I can lift at will each curvèd lid, And my fair dream most highly realize. The time will come, 'tis ushered by my sighs,

When I may shape the dark, but vainly bid

True light restore that form, those looks, that smile.'

'The garden trees are busy with the shower

That fell ere sunset : now methinks they talk,

Lowly and sweetly as befits the hour,

One to another down the grassy walk.

Hark the laburnum from his opening flower,

This cheery creeper greets in whisper light,

While the grim fir, rejoicing in the night,

Hoarse mutters to the murmuring sycamore, ${ }^{1}$

What shall I deem their converse? would they hail

The wild grey light that fronts yon massive cloud,

Or the half bow, rising like pillar'd fire?

Or are they fighting faintly for desire

That with May dawn their leaves may be o'erflowed, And dews about their feet may never fail ?'

In the Essay, entitled Theodicaa Novissima, from which the following passages are taken, to the great injury in its general effect, he sets himself to the task of doing his utmost to clear up the mystery of

1 This will remind the reader of a fine passage in Edwin the Fair, on the specific differences in the sounds made by the ash, the elm, the fir, etc., when moved by the wind; and of some lines by Landor on flowers speaking to each other; and of something more exquisite than either, in Consuelothe description of the flowers in the old monastic garden, at the 'sweet, hour of prime.' 
the existence of such things as sin and suffering in the universe of a being like God. He does it fearlessly, but like a child. It is in the spirit of his friend's words, -

'An infant crying in the night, An infant crying for the light, And with no language but a cry.'

'Then was I as a child that cries, But, crying, knows his father near.'

It is not a mere exercitation of the intellect, it is an endeavour to get nearer God-to assert his eternal Providence, and vindicate his ways to men. We know no performance more wonderful for such a boy. Pascal might have written it. As was to be expected, the tremendous subject remains where he found it-his glowing love and genius cast a gleam here and there across its gloom; but it is brief as the lightning in the collied night-the jaws of darkness do devour it up-this secret belongs to God. Across its deep and dazzling darkness, and from out its abyss of thick cloud, 'all dark, dark, irrecoverably dark,' no steady ray has ever, or will ever, come-over its face its own darkness must brood, till $\mathrm{He}$ to whom alone the darkness and the light are both alike, to whom the night shineth as the day, says, 'Let there be light!' There is, we all know, a certain awful attraction, a nameless charm for all thoughtful spirits, in this mystery, 'the greatest in 
the universe,' as Mr. Hallam truly says ; and it is well for us at times, so that we have pure eyes and a clean heart, to turn aside and look into its gloom ; but it is not good to busy ourselves in clever speculations about it, or briskly to criticise the speculations of others-it is a wise and pious saying of Augustine, Verius cogitatur Deus, quam dicitur; et verius est quam cogitatur.

'I wish to be understood as considering Christianity in the present Essay rather in its relation to the intellect, as constituting the higher philosophy, than in its far more important bearing upon the hearts and destinies of us all. I shall propose the question in this form, "Is there ground for believing that the existence of moral evil is absolutely necessary to the fulfilment of God's essential love for Christ?" (i.e., of the Father for Christ, or of $\dot{x} \pi \alpha \tau \dot{\eta} \rho$

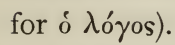

" "Can man by searching find out God?" I believe not. I believe that the unassisted efforts of man's reason have not established the existence and attributes of Deity on so sure a basis as the Deist imagines. However sublime may be the notion of a supreme original mind, and however naturally human feelings adhered to it, the reasons by which it was justified were not, in my opinion, sufficient to clear it from considerable doubt and confusion. . . . I hesitate not to say that I derive from Revelation a 
conviction of Theism, which, without that assistance, would have been but a dark and ambiguous hope. I see that the Bible fits into every fold of the human heart. I am a man, and I believe it to be God's book because it is man's book. It is true that the Bible affords me no additional means of demonstrating the falsity of Atheism ; if mind had nothing to do with the formation of the Universe, doubtless whatever had was competent also to make the Bible; but I have gained this advantage, that my feelings and thoughts can no longer refuse their assent to what is evidently framed to engage that assent; and what is it to me that I cannot disprove the bare logical possibility of my whole nature being fallacious? To seek for a certainty above certainty, an evidence beyond necessary belief, is the very lunacy of scepticism: we must trust our own faculties, or we can put no trust in anything, save that moment we call the present, which escapes us while we articulate its name. I am determined therefore to receive the Bible as Divinely authorized, and the scheme of human and Divine things which it contains, as essentially true.'

'I may further observe, that however much we should rejoice to discover that the eternal scheme of God-the necessary completion, let us remember, of his Almighty Nature-did not require the absolute perdition of any spirit called by Him into existence, we are certainly not entitled to consider the per- 


\section{Arthur H. Hallam.}

petual misery of many individuals as incompatible with sovereign love.'

'In the Supreme Nature those two capacities of Perfect Love and Perfect Joy are indivisible. Holiness and Happiness, says an old divine, are two several notions of one thing. Equally inseparable are the notions of Opposition to Love and Opposition to Bliss. Unless therefore the heart of a created being is at one with the heart of God, it cannot but be miserable. Moreover, there is no possibility of continuing for ever partly with God and partly against him : we must either be capable by our nature of entire accordance with $\mathrm{His}$ will, or we must be incapable of anything but misery, further than He may for awhile " not impute our trespasses to us," that is, He may interpose some temporary barrier between sin and its attendant pain. For in the Eternal Idea of God a created spirit is perhaps not seen, as a series of successize states, of which some that are evil might be compensated by others that are good, but as one indivisible object of these almost infinitely divisible modes, and that either in accordance with His own nature, or in opposition to it.

'Before the gospel was preached to man, how could a human soul have this love, and this consequent life? I see no way; but now that Christ has excited our love for him by showing unutterable love for us; now that we know him as an Elder Brother, 
a being of like thoughts, feelings, sensations, sufferings, with ourselves, it has become possible to love as God loves, that is, to love Christ, and thus to become united in heart to God. Besides, Christ is the express image of God's person : in loving him we are sure we are in a state of readiness to love the Father, whom we see, he tells us, when we see him. Nor is this all : the tendency of love is towards a union so intimate as virtually to amount to identification; when then by affection towards Christ we have become blended with his being, the beams of eternal love, falling, as ever, on the one beloved object, will include us in him, and their returning flashes of love out of his personality will carry along with them some from our own, since ours has become confused with his, and so shall we be one with Christ, and through Christ with God. Thus then we see the great effect of the Incarnation, as far as our nature is concerned, was to render human love for the Most High a possible thing. The law had said, "Thou shalt love the Lord thy God with all thy soul, and with all thy mind, and with all thy strength;" and could men have lived by law, "which is the strength of sin," verily righteousness and life would have been by that law. But it was not possible, and all were concluded under sin, that in Christ might be the deliverance of all. I believe that Redemption' (i.e., what Christ has done and 
suffered for mankind) 'is universal, in so far as it left no obstacle between man and God, but man's own will: that indeed is in the power of God's election, with whom alone rest the abysmal secrets of personality; but as far as Christ is concerned, his death was for all, since his intentions and affections were equally directed to all, and "none who come to him will he in any wise cast out."

"I deprecate any hasty rejection of these thoughts as novelties. Christianity is indeed, as St. Augustin says, "pulchritudo tam antiqua ;" but he adds, " tam nova," for it is capable of presenting to every mind a new face of truth. The great doctrine which in my judgment these observations tend to strengthen and illumine, the doctrine of personal love for a personal God, is assuredly no novelty, but has in all times been the vital principle of the Church. Many are the forms of antichristian heresy, which for a season have depressed and obscured that principle of life, but its nature is conflictive and resurgent ; and neither the Papal Hierarchy with its pomp of systematized errors, nor the worst apostasy of latitudinarian Protestantism, have ever so far prevailed, but that many from age to age have proclaimed and vindicated the eternal gospel of love, believing, as I also firmly believe, that any opinion which tends to keep out of sight the living and loving God, whether it substitute for Him an idol, an occult agency, or 
a formal creed, can be nothing better than a vain and portentous shadow projected from the seifish darkness of unregenerate man.'

The following is from the Review of Tennyson's Poems; we do not know that during the lapse of eighteen years anything better has been said :-

' Undoubtedly the true poet addresses himself, in all his conceptions, to the common nature of us all. Art is a lofty tree, and may shoot up far beyond our grasp, but its roots are in daily life and experience. Every bosom contains the elements of those complex emotions which the artist feels, and every head can, to a certain extent, go over in itself the process of their combination, so as to understand his expressions and sympathize with his state. But this requires exertion; more or less, indeed, according to the difference of occasion, but always some degree of exertion. For since the emotions of the poet during composition follow a regular law of association, it follows that to accompany their progress up to the harmonious prospect of the whole, and to perceive the proper dependence of every step on that which preceded, it is absolutely necessary to start from the same point, i.e., clearly to apprehend that leading sentiment of the poet's mind, by their conformity to which the host of suggestions are arranged. Now this requisite exertion is not willingly made by the large majority of readers. It is so easy 
to judge capriciously, and according to indolent impulse!'

'Those different powers of poetic disposition, the energies of Sensitive, of Reflective, or Passionate emotion, which in former times were intermingled, and derived from mutual support an extensive empire over the feelings of men, were now restrained within separate spheres of agency. The whole svstem no longer worked harmoniously, and by intrinsic harmony acquired external freedom; but there arose a violent and unusual action in the several component functions, each for itself, all striving to reproduce the regular power which the whole had once enjoyed. Hence the melancholy which so evidently characterizes the spirit of modern poetry; hence that return of the mind upon itself, and the habit of seeking relief in idiosyncrasies rather than community of interest. In the old times the poetic impulse went along with the general impulse of the nation.

'One of the faithful Islâm, a poet in the truest and highest sense, we are anxious to present to our readers. . . He sees all the forms of Nature with the "eruditus oculus," and his ear has a fairy fineness. There is a strange earnestness in his worship of beauty, which throws a charm over his impassioned song, more easily felt than described, and not to be escaped by those who have once felt it. 


\section{Hora Subseciva.}

We think that he has more definiteness and roundness of general conception than the late Mr. Keats, and is much more free from blemishes of diction and hasty capriccios of fancy. . . . The author imitates nobody; we recognise the spirit of his age, but not the individual form of this or that writer. His thoughts bear no more resemblance to Byron or Scott, Shelley or Coleridge, than to Homer or Calderon, Ferdusi or Calidasa. We have remarked five distinctive excellencies of his own manner. First, his luxuriance of imagination, and at the same time his control over it. Secondly, his power of embodying himself in ideal characters, or rather modes of character, with such extreme accuracy of adjustment, that the circumstances of the narration seem to have a natural correspondence with the predominant feeling, and, as it were, to be evolved from it by assimilative force. Thirdly, his vivid, picturesque delineation of objects, and the peculiar skill with which he holds all of them fused, to borrow a metaphor from science, in a medium of strong emotion. Fourthly, the variety of his lyrical measures, and exquisite modulation of harmonious words and cadences to the swell and fall of the feelings expressed. Fifthly, the elevated habits of thought, implied in these compositions, and imparting a mellow soberness of tone, more impressive, to our minds, than if the author had drawn up a set of opinions in verse, and sought 
to instruct the understanding, rather than to communicate the love of beauty to the heart.'

What follows is justly thought and well said.

'And is it not a noble thing, that the English tongue is, as it were, the common focus and point of union to which opposite beauties converge? Is it a trifle that we temper energy with softness, strength with flexibility, capaciousness of sound with pliancy of idiom? Some, I know, insensible to these virtues, and ambitious of I know not what unattainable decomposition, prefer to utter funereal praises over the grave of departed Anglo-Saxon, or, starting with convulsive shudder, are ready to leap from surrounding Latinisms into the kindred, sympathetic arms of modern German. For myself, I neither share their regret, nor their terror. Willing at all times to pay filial homage to the shades of Hengist and Horsa, and to admit they have laid the base of our compound language; or, if you will, have prepared the soil from which the chief nutriment of the goodly tree, our British oak, must be derived, I am yet proud to confess that I look with sentiments more exulting and more reverential to the bonds by which the law of the universe has fastened me to my distant brethren of the same Caucasian race; to the privileges which I, an inhabitant of the gloomy North, share in common with climates imparadised in perpetual summer, to the universality and efficacy 
resulting from blended intelligence, which, while it endears in our eyes the land of our fathers as a seat of peculiar blessing, tends to elevate and expand our thoughts into communion with humanity at large; and, in the "sublimer spirit" of the poet, to make us feel

"That God is everywhere-the God who framed

Mankind to be one mighty family,

Himself our Father, and the world our home."

What nice shading of thought do his remarks on Petrarch discover !

'But it is not so much to his direct adoptions that I refer, as to the general modulation of thought, that clear softness of his images, that energetic selfpossession of his conceptions, and that melodious repose in which are held together all the emotions he delineates.'

Every one who knows anything of himself, and of his fellow-men, will acknowledge the wisdom of what follows. It displays an intimate knowledge both of the constitution and history of man, and there is much in it suited to our present need :-

' I do not hesitate to express my conviction, that the spirit of the critical philosophy, as seen by its fruits in all the ramifications of art, literature, and morality, is as much more dangerous than the spirit of mechanical philosophy, as it is fairer in appearance, and more capable of alliance with our natural feelings of en- 
thusiasm and delight. Its dangerous tendency is this, that it perverts those very minds, whose office it was to resist the perverse impulses of society, and to proclaim truth under the dominion of falsehood. However precipitate may be at any time the current of public opinion, bearing along the mass of men to the grosser agitations of life, and to such schemes of belief as make these the prominent objects, there will always be in reserve a force of antagonistic opinion, strengthened by opposition, and attesting the sanctity of those higher principles which are despised or forgotten by the majority. These men are secured by natural temperament and peculiar circumstances from participating in the common delusion : but if some other and deeper fallacy be invented; if some more subtle beast of the field should speak to them in wicked flattery; if a digest of intellectual aphorisms can be substituted in their minds for a code of living truths, and the lovely semblances of beauty, truth, affection, can be made first to obscure the presence, and then to conceal the loss, of that religious humility, without which, as their central life, all these are but dreadful shadows; if so fatal a stratagem can be successfully practised, I see not what hope remains for a people against whom the gates of hell have so prevailed.'

'But the number of pure artists is small : few souls are so finely tempered as to preserve the de- 
licacy of meditative feeling, untainted by the allurements of accidental suggestion. The voice of the critical conscience is still and small, like that of the moral : it cannot entirely be stifled where it has been heard, but it may be disobeyed. Temptations are never wanting: some immediate and temporary effect can be prorluced at less expense of inward exertion than the high and more ideal effect which art demands: it is much easier to pander to the ordinary and often recurring wish for excitement, than to promote the rare and difficult intuition of beauty. To raise the many to his ozon real point of view, the artist must employ his energies, and create energy in others: to descend to their position is less noble, but practicable with ease. If I may be allowed the metaphor, one partakes of the nature of redemptive power; the other of that self-abased and degenerate will, which "flung from his splendours" the fairest star in heaven.'

'Revelation is a voluntary approximation of the Infinite Being to the way's and thoughts of finite humanity. But until this step has been taken by Almighty Grace, how should man have a warrant for loving with all his heart and mind and strength? . . . . Without the gospel, nature exhibits a want of harmony between our intrinsic constitution and the system in which it is placed. But Christianity has made up the difference. It is possible and natural 
to love the Father, who has made us his children by the spirit of adoption : it is possible and natural to love the Elder Brother, who was, in all things, like as we are, except sin, and can succour those in temptation, having been himself tempted. Thus the Christian faith is the necessary complement of a sound ethical system.'

There is something to us very striking in the words 'Revelation is a voluntary approximation of the Infinite Being.' This states the case with an accuracy and a distinctness not at all common among either the opponents or the apologists of revealed religion in the ordinary sense of the expression. In one sense God is for ever revealing himself. His heavens are for ever telling his glory, and the firmament showing his handiwork; day unto day is uttering speech, and night unto night is showing knowledge concerning him. But in the word of the truth of the gospel, God draws near to his creatures; he bows his heavens, and comes down :

'That glorious form, that light unsufferable, And that far-beaming blaze of majesty,'

he lays aside. The Word dwelt with men. 'Come then, let us reason together ;'-'Waiting to be gracious ;'- 'Behold, I stand at the door, and knock; if any man open to me, I will come in to him, and sup with him, and he with me.' It is the father seeing his son while yet a great way off, and 
having compassion, and running to him and falling on his neck and kissing him; for 'it was meet for us to rejoice, for this my son was dead and is alive again, he was lost and is found.' Let no man confound the voice of God in his Works with the voice of God in his Word; they are utterances of the same infinite heart and will; they are in absolute harmony; together they make up 'that undisturbèd song of pure concent;' one 'perfect diapason ;' but they are distinct; they are meant to be so. A poor traveller, 'weary and waysore,' is stumbling in unknown places through the darkness of a night of fear, with no light near him, the everlasting stars twinkling far off in their depths, and yet unrisen sun, or the waning moon, sending up their pale beams into the upper heavens, but all this is distant and bewildering for his feet, doubtless better much than outer darkness, beautiful and full of God, if he could have the heart to look up, and the eyes to make use of its vague light; but he is miserable, and afraid, his next step is what he is thinking of; a lamp secured against all winds of doctrine is put into his hands, it may in some respects widen the circle of darkness, but it will cheer his feet, it will tell them what to do next. What a silly fool he would be to throw away that lantern, or draw down the shutters, and make it dark to him, while it sits ' $\mathrm{i}$ ' the centre and enjoys bright 
day,' and all upon the philosophical ground that its light was of the same kind as the stars', and that it was beneath the dignity of human nature to do anything but struggle on and be lost in the attempt to get through the wilderness and the night by the guidance of those 'natural' lights, which, though they are from heaven, have so often led the wanderer astray. The dignity of human nature indeed! Let him keep his lantern till the glad sun is up, with healing under his wings. Let

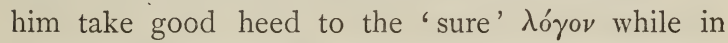

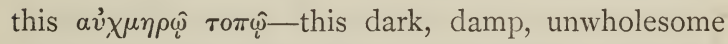

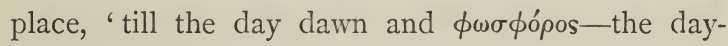
star-arise.' Nature and the Bible, the Works and the Word of God, are two distinct things. In the mind of their Supreme Author they dwell in perfect peace, in that unspeakable unity which is of his essence; and to us his children, every day their harmony, their mutual relations, are discovering themselves; but let us beware of saying all nature is a revelation as the Bible is, and all the Bible is natural as nature is: there is a perilous juggle here.

The following passage develops Arthur Hallam's views on religious feeling; this was the master idea of his mind, and it would not be easy to overrate its importance. 'My son, give me thine heart;' 'Thou shalt love the Lord thy God;'-'The fool 
hath said in his heart, There is no God.' He expresses the same general idea in these words, remarkable in themselves, still more so as being the thought of one so young. 'The work of intellect is posterior to the work of feeling. The latter lies at the foundation of the man; it is his proper self--the peculiar thing that characterizes him as an individual. No two men are alike in feeling; but conceptions of the understanding, when distinct, are precisely similar in all-the ascertained relations of truths are the common property of the race.'

- Tennyson, we have no doubt, had this thought of his friend in his mind, in the following lines; it is an answer to the question, Can man by searching find out God? -

' I found Him not in world or sun,

Or eagle's wing, or insect's eye ;

Nor thro' the questions men may try,

The petty cobwebs we have spun :

'If e'er when faith had fallen asleep,

I heard a voice "believe no more,"

And heard an ever-breaking shore

That tumbled in the godless deep ;

'A warmth within the breast would melt

The freezing reason's colder part,

And like a man in wrath, the heart

Stood up and answer'd, "I have felt."

' No, like a child in doubt and fear :

But that blind clamour made me wise;

Then was I as a child that cries,

But, crying, knows his father near ; 
'And what I seem beheld again

What is, and no man understands :

And out of darkness came the hands

That reach thro' nature, moulding men.'

This is a subject of the deepest personal as well as speculative interest. In the works of Augustin, of Baxter, Howe, and Jonathan Edwards, and of Alexander Knox, our readers will find how large a place the religious affections held in their view of Divine truth as well as of human duty. The last-mentioned writer expresses himself thus :- 'Our sentimental faculties are far stronger than our cogitative; and the best impressions on the latter will be but the moonshine of the mind, if they are alone. Feeling will be best excited by sympathy; rather, it cannot be excited in any other way. Heart must act upon heart-the idea of a living person being essential to all intercourse of heart. You cannot by any possibility cordialize with a mere ens rationis. "The Word was made flesh, and dwelt among us," otherwise we could not have "beheld his glory," much less "received of his fulness." 1

Our young author thus goes on :-

'This opens upon us an ampler view in which the subject deserves to be considered, and a relation still more direct and close between the Christian religion and the passion of love. What is the dis-

${ }^{1}$ Remains, vol. iii. p. 105. 
tinguishing character of Hebrew literature, which separates it by so broad a line of demarcation from that of every ancient people? Undoubtedly the sentiment of erotic devotion which pervades it. Their poets never represent the Deity as an impassive principle, a mere organizing intellect, removed at infinite distance from human hopes and fears. $\mathrm{He}$ is for them a being of like passions with themselves, ${ }^{1}$ requiring heart for heart, and capable of inspiring affection because capable of feeling and returning it. Awful indeed are the thunders of his utterance and the clouds that surround his dwelling-place; very terrible is the vengeance he executes on the nations that forget him : but to his chosen people, and especially to the men "after his own heart," whom he anoints from the midst of them, his "still, small voice" speaks in sympathy and loving-kindness. Every Hebrew, while his breast glowed with patriotic enthusiasm at those promises, which he shared as one of the

1 'An unfortunate reference (Acts xiv. I5), for the apostle's declaration is, that he and his brethren were of "like passions" (James v. I7); - liable to the same imperfections and mutations of thought and feeling as other men, and as the Lystrans supposed their gods to be ; while the God proclaimed by him to them is not so. And that God is the God of the Jews as well as of the Christians; for there is but one God. Hallam's thought is an important and just one, but not developed with his usual nice accuracy.'

For this note, as for much else, I am indebted to my father, whose powers of compressed thought I wish I had inherited. 


\section{Arthur H. Hallam.}

favoured race, had a yet deeper source of emotion, from which gushed perpetually the aspirations of prayer and thanksgiving. He might consider himself alone in the presence of his God; the single being to whom a great revelation had been made, and over whose head an "exceeding weight of glory" was suspended. For him the rocks of Horeb had trembled, and the waters of the Red Sea were parted in their course. The word given on Sinai with such solemn pomp of ministration was given to his own individual soul, and brought him into immediate communion with his Creator. That awful Being could never be put away from him. He was about his path, and about his bed, and knew all his thoughts long before. Yet this tremendous, enclosing presence was a presence of love. It was a manifold, everlasting manifestation of one deep feeling - a desire for human affection. ${ }^{1}$ Such a belief, while it enlisted even pride and self-interest on the side of piety, had a direct tendency to excite the best passions of our nature. Love is not long asked in vain from generous dispositions. A Being, never absent, but standing beside the life of each man with ever-watchful tenderness, and recognised, though invisible, in every blessing that befel them from youth to age, became naturally

1 Abraham 'was called the friend of God;' 'with him (Moses) will I (Jehovah) speak mouth to mouth, even apparently,''as a man to his friend;' David was 'a man after mine own heart.' 
the object of their warmest affections. Their belief in him could not exist without producing, as a necessary effect, that profound impression of passionate individual attachment which in the Hebrew authors always mingles with and vivifies the.r faith in the Invisible. All the books of the Old Testament are breathed upon by this breath of life. Especially is it to be found in that beautiful collection, entitled the Psalms of David, which remains, after some thousand years, perhaps the most perfect form in which the religious sentiment of man has been embodied.

"But what is true of Judaism is yet more true of Christianity: "matre pulchrô filia pulchrior." In addition to all the characters of Hebrew Monotheism, there exists in the doctrine of the Cross a peculiar and inexhaustible treasure for the affectionate feelings. The idea of the $\theta \epsilon \alpha \nu \theta \rho \omega \pi$ os, the God whose goings forth have been from everlasting, yet visible to men for their redemption as an earthly, temporal creature, living, acting, and suffering among themselves, then (which is yet more important) transferring to the unseen place of his spiritual agency the same humanity he wore on earth, so that the lapse of generations can in no way affect the conception of his identity; this is the most powerful thought that ever addressed itself to a human imagination. It is the $\pi \circ v \sigma \tau \hat{\omega}$, which alone was wanted to move the world. Here was solved at once the great problem which so long 
had distressed the teachers of mankind, how to make virtue the object of passion, and to secure at once the warmest enthusiasm in the heart with the clearest perception of right and wrong in the understanding. The character of the blessed Founder of our faith became an abstract of morality to determine the judgment, while at the same time it remained personal, and liable to love. The written word and established church prevented a degeneration into ungoverned mysticism, but the predominant principle of vital religion always remained that of self-sacrifice to the Saviour. Not only the higher divisions of moral duties, but the simple, primary impulses of benevolence, were subordinated to this new absorbing passion. The world was loved "in Christ alone." The brethren were members of his mystical body. All the other bonds that had fastened down the spirit of the universe to our narrow round of earth were as nothing in comparison to this golden chain of suffering and self-sacrifice, which at once riveted the heart of man to one who, like himself, was acquainted with grief. Pain is the deepest thing we have in our nature, and union through pain has always seemed more real and more holy than any other.' 1

${ }^{1}$ This is the passage referred to in Henry Taylor's delightfui Notes from Life ('Essay on Wisdom') :-

' Fear, indeed, is the mother of foresight : spiritual fear, of a foresight that reaches beyond the grave; temporal fear, of a foresight that falls short; but without fear there is neither the 
There is a sad pleasure,-non ingrata amaritudo, and a sort of meditative tenderness in contemplating the little life of this 'dear youth,' and in letting the mind rest upon these his earnest thoughts; to watch his keen and fearless, but childlike spirit, moving itself aright-going straight onward along 'the lines of limitless desires'-throwing himself into the very deepest of the ways of God, and striking out as a strong swimmer striketh out his hands to swim; to see him 'mewing his mighty youth, and kindling his undazzled eye at the fountain itself of heavenly radiance :'

Light intellectual, and full of love,

Love of true beauty, therefore full of joy,

Joy, every other sweetness far above.'

It is good for every one to look upon such a sight, and as we look, to love. We should all be the better for it; and should desire to be thankful for, and to use aright a gift so good and perfect, coming down as it does from above, from the Father of one foresight nor the other ; and as pain has been truly said to be "the deepest thing in our nature," so is it fear that will bring the depths of our nature within our knowledge. A great capacity of suffering belongs to genius; and it has been observed that an alternation of joyfulness and dejection is quite as characteristic of the man of genius as intensity in either kind.' In his Notes from Books, p. 216, he recurs to it:- "“Pain," says a writer whose early death will not prevent his being long remembered, " pain is the deepest thing that we have in our nature, and union through pain has always seemed more real and more holy than any other.", 
lights, in whom alone there is no variableness, neither shadow of turning.

Thus it is, that to each one of us the death of Arthur Hallam-his thoughts and affections-his views of God, of our relations to Him, of duty, of the meaning and worth of this world and the next,where he now is, have an individual significance. $\mathrm{He}$ is bound up in our bundle of life; we must be the better or the worse of having known what manner of man he was; and in a sense less peculiar, but not less true, each of us may say,

- 'The tender grace of a day that is dead Will never come back to me.'

- 'O for the touch of a vanished hand, And the sound of a voice that is still!'

' God gives us love! Something to love He lends us; but when love is grown To ripeness, that on which it throve Falls off, and love is left alone :

' This is the curse of time. Alas !

In grief we are not all unlearned;

Once, through our own doors Death did pass ;

One went, who never hath returned.

' This star

Rose with us, through a little arc Of heaven, nor having wandered far,

Shot on the sudden into dark.

' Sleep sweetly, tender heart, in peace ;

Sleep, holy spirit, blessed soul, While the stars burn, the moons increase,

And the great ages onward roli. 
- Sleep till the end, true soul and sweet,

Nothing comes to thee new or strange,

Sleep, full of rest from head to feet ;

Lie still, dry dust, secure of change.'

Vattene in pace, alma beata e bella.-Go in peace, soul beautiful and blessed.

' $\mathrm{O}$ man greatly beloved, go thou thy way till the end, for thou shalt rest, and stand in thy lot at the end of the days.'-DanieL.

'Lord, I have viewed this world over, in which thou hast set me; I have tried how this and that thing will fit my spirit, and the design of my creation, and can find nothing on which to rest, for nothing here doth itself rest, but such things as please me for a while, in some degree, vanish and flee as shadows from before me. Lo! I come to Thee-the Eternal Being - the Spring of Life-the Centre of rest-the Stay of the Creation-the Fulness of all things. I join myself to Thee; with Thee I will lead my life, and spend my days, with whom I aim to dwell for ever, expecting, when my little time is over, to be taken up ere long into thy eternity.'-JoHN Howe, The Vanity of Man as Mortal.

Necesse est tanquam immaturam mortem ejus defleam: si tamen fas est aut flere, aut omnino mortem 
vocare, quâ tanti juvenis mortalitas magis finita quam vita est. Vivit enim, vivetque semper, atque etiam latius in memoria hominum et sermone versabitur, postquam ab oculis recessit.

The above notice was published in $185 \mathrm{r}$. On sending to Mr. Hallam a copy of the Review in which it appeared, I expressed my hope that he would not be displeased by what I had done. I received the following kind and beautiful reply :-

\section{'Wilton Crescent, Feb: 'x, I851.}

'Dear Sir,-It would be ungrateful in me to feel any displeasure at so glowing an eulogy on my dear eldest son Arthur, though after such a length of time, so unusual, as you have written in the North British Review. I thank you, on the contrary, for the strong language of admiration you have employed, though it may expose me to applications for copies of the Remains, which I have it not in my power to comply with. I was very desirous to have lent you a copy, at your request, but you have succeeded elsewhere.

'You are probably aware that I was prevented from doing this by a great calamity, very similar in its circumstances to that I had to deplore in 1833 -the loss of another son, equal in virtues, hardly inferior in abilities, to him whom you have commemorated. This has been an unspeakable affliction to me, and at my advanced age, seventy-three years, I can have no resource but the hope, in God's mercy, of a reunion with them both. The resemblance in their characters was striking, and I had often reflected how wonderfully my first loss had been repaired by the substitution, as it might be called, of one so closely representing his brother. I send you a brief Memoir, 
drawn up by two friends, with very little alteration of my own. -I am, Dear Sir, faithfully yours,

'Dr. Brown, Edinburgh.'

HENRY HALLAM.

The following extracts, from the Memoir of Henry Fitzmaurice Hallam mentioned above, which has been appended to a reprint of his brother's Remains (for private circulation), form a fitting close to this memorial of these two brothers, who were 'lovely and pleasant in their lives,' and are now by their deaths not divided :-

'But few months have elapsed since the pages of In Memoriam recalled to the minds of many, and impressed on the hearts of all who perused them, the melancholy circumstances attending the sudden and early death of Arthur Henry Hallam, the eldest son of Henry Hallam, Esq. Not many weeks ago the public journals contained a short paragraph announcing the decease, under circumstances equally distressing, and in some points remarkably similar, of Henry Fitzmaurice, Mr. Hallam's younger and only remaining son. No one of the very many who appreciate the sterling value of Mr. Hallam's literary labours, and who feel a consequent interest in the character of those who would have sustained 


\section{Arthur H. Hallam.}

the eminence of an honourable name; no one who was affected by the striking and tragic fatality of two such successive bereavements, will deem an apology needed for this short and imperfect Memoir.

'Henry Fitzmaurice Hallam, the younger son of Henry Hallam, Esq., was born on the 3 rst of August I 824 ; he took his second name from his godfather, the Marquis of Lansdowne. . . . A habit of reserve, which characterized him at all periods of life, but which was compensated in the eyes of even his first companions by a singular sweetness of temper, was produced and fostered by the serious thoughtfulness ensuing upon early familiarity with domestic sorrow.

" "He was gentle," writes one of his earliest and closest school-friends, "retiring, thoughtful to pensiveness, affectionate, without envy or jealousy, almost without emulation, impressible, but not wạnting in moral firmness. No one was ever more formed for friendship. In all his words and acts he was simple, straightforward, true. He was very religious. Religion had a real effect upon his character, and made him tranquil about great things, though he was so nervous about little things."

'He was called to the bar in Trinity Term, r850, and became a member of the Midland Circuit in the summer. Immediately afterwards he joined his family in a tour on the Continent. They had spent 
the early part of the autumn at Rome, and were returning northwards, when he was attacked by a sudden and severe illness, affecting the vital powers, and accompanied by enfeebled circulation and general prostration of strength. He was able, with difficulty, to reach Sienna, where he sank rapidly through exhaustion, and expired on Friday, October 25. It is to be hoped that he did not experience any great or active suffering. He was conscious nearly to the last, and met his early death (of which his presentiments, for several years, had been frequent and very singular) with calmness and fortitude. There is reason to apprehend, from medical examination, that his life would not have been of very long duration, even had this unhappy illness not occurred. But for some years past his health had been apparently much improved; and, secured as it seemed to be by his unintermitted temperance, and by a carefulness in regimen which his early feebleness of constitution had rendered habitual, those to whom he was nearest and dearest had, in great measure, ceased to regard him with anxiety. His remains were brought to England, and he was interred, on December $23 \mathrm{~d}$, in Clevedon Church, Somersetshire, by the side of his brother, his sister, and his mother.

'For continuous and sustained thought he had an extraordinary capacity, the bias of his mind being 
decidedly towards analytical processes; a characteristic which was illustrated at Cambridge by his uniform partiality for analysis, and comparative distaste for the geometrical method, in his mathematical studies. His early proneness to dwell upon the more recondite departments of each science and branch of inquiry has been alluded to above. It is not to be inferred that, as a consequence of this tendency, he blinded himself, at any period ot his life, to the necessity and the duty of practical exertion. He was always eager to act as well as speculate; and, in this respect, his character preserved an unbroken consistency and harmony from the epoch when, on commencing his residence at Cambridge, he voluntarily became a teacher in a parish Sunday-school, for the sake of applying his theories of religious education, to the time when, on the point of setting forth on his last fatal journey, he framed a plan of obtaining access, in the ensuing winter, to a large commercial establishment, in the view of familiarizing himself with the actual course and minute detail of mercantile transactions.

'Insensibly and unconsciously he had made himself a large number of friends in the last few years of his life: the painful impression created by his death in the circle in which he habitually moved, and even beyond it, was exceedingly remarkable, 
486 Hore Subseciva.

both for its depth and extent. For those united with him in a companionship more than ordinarily close, his friendship had taken such a character as to have almost become a necessity of existence. But it was upon his family that he lavished all the wealth of his disposition - affection without stint, gentleness never once at fault. considerateness reaching to self-sacrifice :-

' Di ciò si biasmi il debolo intelletto E 'l parlar nostro, che non ha valore Di ritrar tutto ciò che dice amore.

H. S. M.

F. L.' 


HOR 开 SUBSECIV丑：Observations and Discourses, small svo. russia extra, gilt edges, by C. LEWIS ; fine copy, with Dr. Bliss's bookplate, and MS. notes, $£ 1.4 s \quad$ E. Blount, 1620 This work is by some attributed to GREY BRYDGES LORD Chandos, by others to Gilbert Cavendish. 


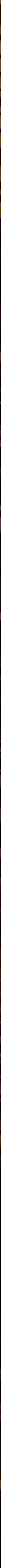




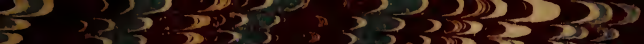

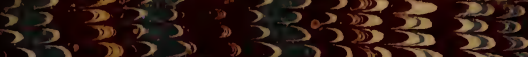

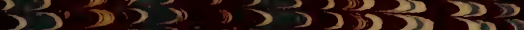

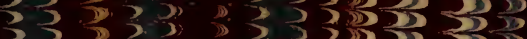
$325,3,3,353$ $35.35 \cdot 32503$ $353,3,3,3323$

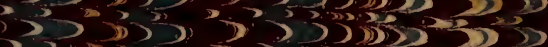

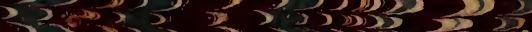

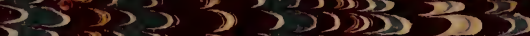

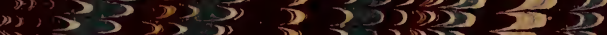

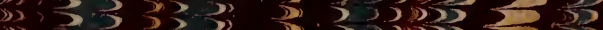

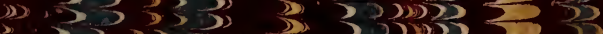

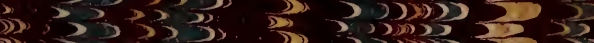

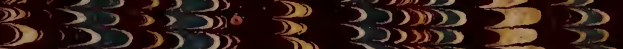
2), $3,3,3,3$

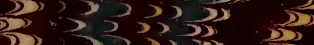

D) 353503513

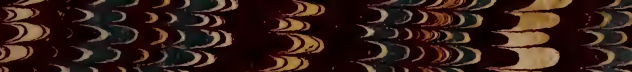
D) $\rightarrow 3,53$ $\sum_{3}, \frac{3}{3}, \frac{53}{32}$

3) $3>35$

)

53

S)

3,35

ii) 2015

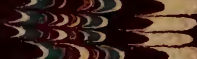

32

(2) >

39335

(3) 2)

$>>35$

(2) 350

$32>3$

3,23

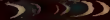

$,>1,3$

$3: 3>$

$>, 3$

3 ,

25

35

35

$\sum_{13}$

353

35

323

325

303

$\rightarrow 2019$

305035

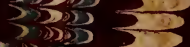

$\rightarrow \rightarrow 3$

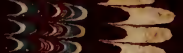

3 is

3.20

().

$3 \frac{D}{D}$

33

$x$ b

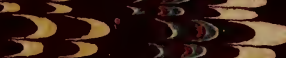

$3 \frac{1.30}{30}$

$\sum_{i \rightarrow \infty}, \infty, 3$

$\sum_{3}, 3,5$

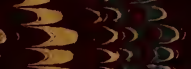

$\sum_{3}^{3} \sum_{3}^{3}$
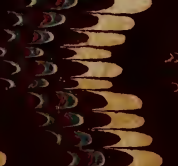

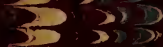

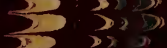

$\sum_{3 \rightarrow \infty}>\frac{3}{3}$

3
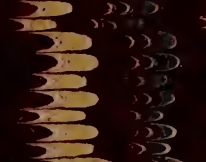

$\sum_{3} 1$

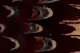

). 35

i) 353

35350

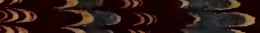

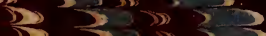

$\sum_{3}-3030, \frac{2}{3}, 3$

(2) 3,3 ?

$\sum_{3 \rightarrow}=390,3$

ग) $\rightarrow 3 \geqslant 3$

ग) 50 ग 3

$325>27$

$35021 \times 5$
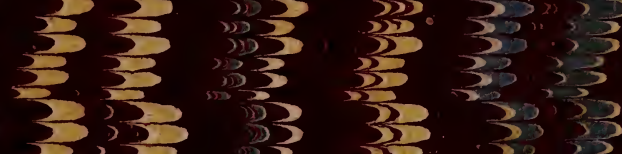

32

$\sum_{3}^{3}$

20

3

$\int_{3}^{3}$

3

3

(1)
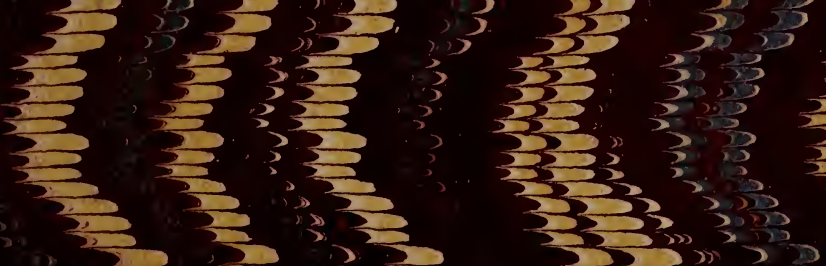

$\sum_{i \rightarrow 3} \rightarrow 3$

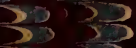

303

$\sum_{3} \times 3$

$32 \div 3$

$\sum_{3}, 5$

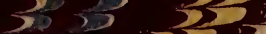

35

(2)

D) ?

ग) 3

3503

$>>3$

3515

$\rightarrow 3$

$33>$

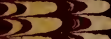

$35>3$

3325

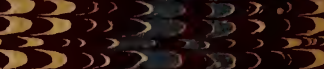

3 3 3

3.5 $>$ $\rightarrow 2$ D) ร) D) 
